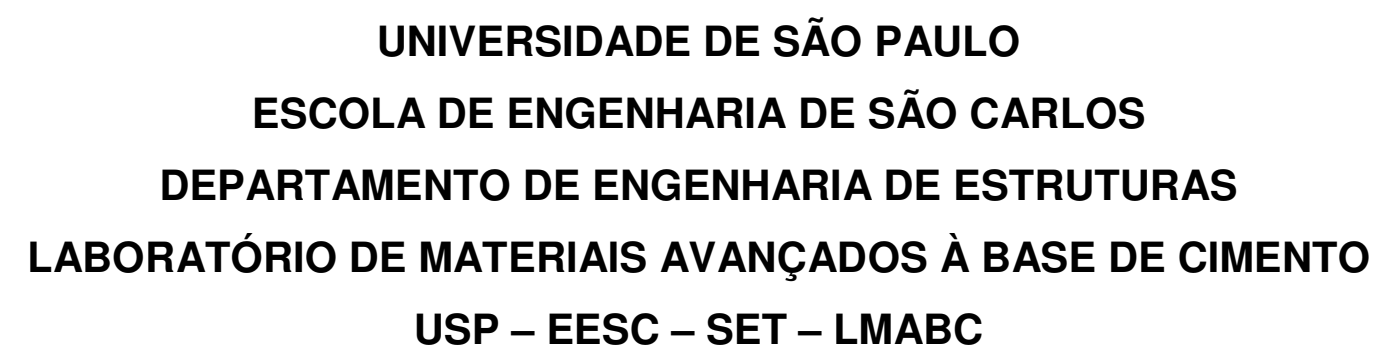

MARKUS SAMUEL REBMANN

DURABILIDADE DE CONCRETOS ESTRUTURAIS COM BAIXO CONSUMO DE CIMENTO PORTLAND E ALTA RESISTÊNCIA

São Carlos

2011 



\title{
DURABILIDADE DE CONCRETOS ESTRUTURAIS COM BAIXO CONSUMO DE CIMENTO PORTLAND E ALTA RESISTÊNCIA
}

\begin{abstract}
Dissertação apresentada à Escola de Engenharia de São Carlos da Universidade de São Paulo como requisito para obtenção do título de Mestre em Engenharia Civil.
\end{abstract}

Área de concentração:

Engenharia de Estruturas

Orientador:

Prof. Dr. Jefferson B. L. Liborio

Versão: corrigida. A versão original encontra-se disponível na Escola de Engenharia de São Carlos - USP.

São Carlos 
AUTORIZO A REPRODUÇÃO E DIVULGAÇÃO TOTAL OU PARCIAL DESTE TRABALHO, POR QUALQUER MEIO CONVENCIONAL OU ELETRÔNICO, PARA FINS DE ESTUDO E PESQUISA, DESDE QUE CITADA A FONTE.

Ficha catalográfica preparada pela Seção de Tratamento da Informação do Serviço de Biblioteca - EESC/USP

Rebmann, Markus Samuel
Durabilidade de concretos estruturais com baixo
Consumo de cimento Portland e alta resistência / Markus
Samuel Rebmann ; orientador Jefferson Benedicto Libardi
Liborio. -- São Carlos, 2011.
Dissertação (Mestrado-Programa de Pós-Graduação em
Engenharia Civil Área de Concentração em Engenharia de
Estruturas) -- Escola de Engenharia de São Carlos da
Universidade de São Paulo, 2011.
1. Concreto de alta resistência. 2. Baixo consumo de
cimento Portland. 3. Durabilidade. 4. Carbonatação. 5.
Abrasão. 6. Potencial de corrosão. 7 . Empacotamento de
partículas. I. Título.


Candidato: Engenheiro MARKUS SAMUEL REBMANN.

Dissertação defendida e julgada em 06/05/2011 perante a Comissão Julgadora:

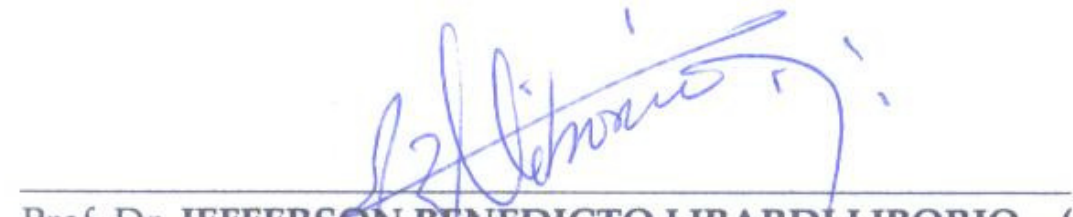

Prof. Dr. JEFFERSON BENEDICTO LIBARDI LIBORIO - (Orientadof)

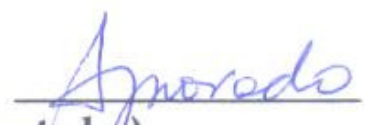

(Instituto de Arquitetura e Urbanismo/USP)

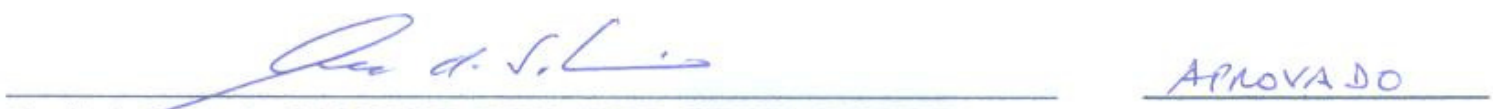

Prof ASSociado MARCIO ROBERTO SILVA CORREA

(Escola de Engenharia de São Carlos/USP)

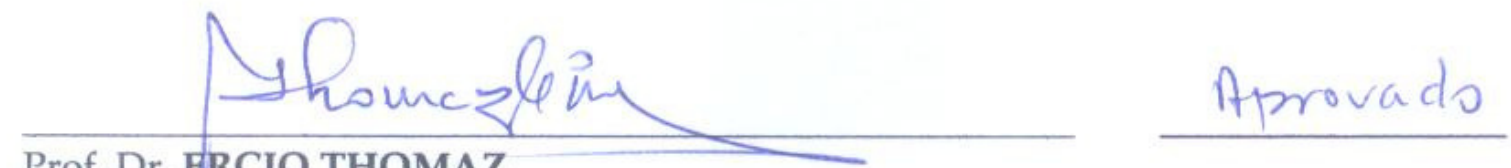

Prof. Dr. ERCIO THOMAZ

(Instituto de Pesquisas Tecnológicas/IPT)

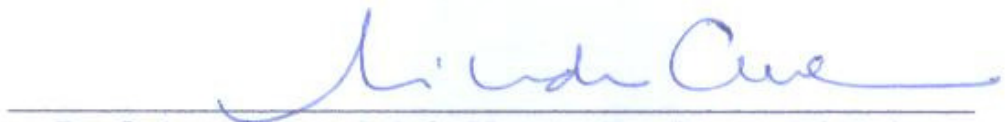

Prof. Assoc. Ana Lúcia Homce De Cresce El Debs

Coordenadora do Programa de Pós-Graduação em

Engenharia Civil (Engenharia de Estruturas)

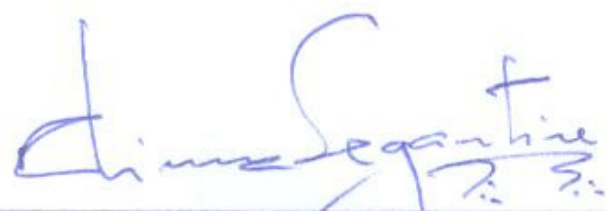

Prof. Associado PAULo CÉSAR LIMA SEGANTINE

Presidente da Comissão de Pós-Graduação 

Quando se conclui uma etapa da vida deve-se olhar para frente na busca de novos horizontes, sem, no entanto, deixar de olhar para trás e avaliar como se chegou ao momento atual. Nada daquilo que foi conquistado seria possível sem a participação de inúmeras pessoas que, de forma direta ou indireta, contribuíram. A todos estes quero aqui prestar os meus sinceros agradecimentos.

A Deus pela vida, a Jesus Cristo pela salvação e ao Espírito Santo pela condução diária.

À minha esposa Franciane pelo amor e carinho dedicado, pela infinita compreensão nos momentos ausentes e pelo auxílio na revisão do texto.

Aos meus pais, Roland e Annerose, por todos os ensinamentos e exemplos de vida que me deram e pelo incentivo constante no aprimoramento profissional. Também aos meus irmãos e demais familiares agradeço por todo amor e alegria compartilhados.

Ao professor Jefferson Liborio pela orientação durante a elaboração desta pesquisa. Agradeço pela confiança em mim depositada, pela oportunidade de integrar o grupo de pesquisa do $L M A B C$ e pelos incontáveis momentos de conversa que ajudaram a definir os rumos da pesquisa.

Aos colegas de laboratório, Rodrigo Vieira da Conceição e Ana Paula Moreno Trigo, pelas horas de discussão sobre as pesquisas em andamento, pela ajuda prática e pela amizade.

Aos colaboradores do LMABC, Jorge Bravo e Wilson Moreira, e aos estagiários, William e Paulo, pela ajuda no dia-a-dia, amizade e descontração nos momentos oportunos.

Aos professores das disciplinas que tive o prazer de cursar durante o mestrado: Jefferson Liborio, José Samuel Giongo, Libânio Pinheiro, João Bento de Hanai, Sergio Proença, Mounir Khalil El Debs, Humberto Coda, Luiz Vareda, João Batista de Paiva e Roberto Gonçalves. Também ao Departamento de Estruturas da EESC e a toda a sua equipe administrativa.

Ao professor José Carlos Cintra pelo empolgante curso de "Oratória e didática no ensino superior", bem como a toda a turma deste curso. Foram momentos inesquecíveis de amizade e crescimento profissional.

Aos diversos laboratórios da EESC com suas equipes: Laboratório de estruturas do SET (Luiz Vareda, Amaury e toda a turma), LAMEM (Sílvio e Samuel), Departamento de Geotecnia (Sr. Antônio Garcia) e Engenharia Ambiental (Janja). Também ao laboratório de 
Vidros do IQSC, à Oficina Mecânica (Luiz Penazzi) e ao Setor de Transportes pelo apoio operacional.

Aos componentes da banca examinadora, em especial aos membros convidados, professores Dr. Ercio Thomaz e Dr. Marcio Correa, pelas valiosas contribuições.

Ao pastor Jarbas Valentim e sua esposa Lucy que me acolheram com tanto carinho em sua casa nas primeiras semanas em São Carlos.

Ao meu amigo Luiz Henrique Fernandez pela amizade, pelas longas horas de conversas sobre os mais variados assuntos e pelos projetos desenvolvidos em parceria.

Aos demais colegas que ingressaram no mestrado em 2009 pela companhia e descontração durante as disciplinas.

Ao CNPq pela concessão de bolsa de estudo, o que viabilizou a minha estada em São Carlos.

Às empresas Holcim Cimentos, BASF Chemical Company, RheoSet, Grace Construction Products, Mineração Jundu, Elkem do Brasil e Metacaulim do Brasil pela doação de materiais para os experimentos.

Enfim, a todos que contribuíram para que este trabalho fosse iniciado e concluído, dedico aqui meus sinceros agradecimentos. 
O tempo dura o suficiente para aqueles que sabem usá-lo.

Leonardo da Vinci 

REBMANN, M. S. Durabilidade de concretos estruturais com baixo consumo de cimento Portland e alta resistência. 2011. 211 p. Dissertação (Mestrado) Departamento de Estruturas, Escola de Engenharia de São Carlos, Universidade de São Paulo, São Carlos - SP, 2011.

Este trabalho apresenta um estudo sobre a confecção de concretos estruturais com baixo consumo de cimento Portland e avalia algumas das suas propriedades no estado fresco e endurecido, tanto em termos mecânicos como de durabilidade. $O$ uso de concretos de baixo consumo de cimento Portland tem por objetivo possibilitar maior sustentabilidade da indústria da construção baseada no concreto, como maior longevidade de jazidas, reduções na emissão de $\mathrm{CO}_{2}$ e no consumo de energia e menores custos de transporte. Possibilita também diversas melhorias técnicas, como menor retração, fissuração e calor de hidratação. Com base em conceitos de empacotamento e dispersão de partículas, uso de adições minerais e fílers e escolha adequada dos materiais, obtiveram-se concretos com baixo consumo de cimento e alta resistência, com consumo relativo de materiais aglomerantes inferior a $5 \mathrm{~kg} / \mathrm{m}^{3}$ para produzir $1 \mathrm{MPa}$ de resistência à compressão. Avaliaram-se diversos parâmetros relacionados à durabilidade destes concretos com base em ensaios de absorção de água por imersão, absorção de água por capilaridade, permeabilidade, abrasão, carbonatação e potencial de corrosão. Os resultados obtidos indicam que os concretos de baixo consumo de cimento obtidos podem ter durabilidade comparável ou até superior a concretos usualmente considerados como de bom desempenho. Observou-se que a durabilidade é dependente do tipo de cimento empregado e que deve ser avaliada especificamente com relação ao tipo de ação agressiva a que o concreto estará exposto.

Palavras-chave: Concreto de alta resistência. Baixo consumo de cimento Portland. Durabilidade. Carbonatação. Abrasão. Potencial de corrosão. Empacotamento de partículas. 
REBMANN, M. S. Durability of high resistance structural concretes produced with low Portland cement consumption. 2011. 211 p. Dissertation (Master Degree) - Departamento de Estruturas, Escola de Engenharia de São Carlos, Universidade de São Paulo, São Carlos - SP, 2011.

This dissertation presents a study on the development of structural concrete with low Portland cement consumption and evaluates some of its fresh and hardened properties, in mechanical and durability terms. The use of low concrete Portland cement consumption is intended to enable greater sustainability of the construction industry based on concrete, as increased longevity of deposits, reductions in $\mathrm{CO}_{2}$ emissions and energy consumption and lower transportation costs. It also allows several technical improvements, such as reduced shrinkage, cracking and hydration heat. Based on particle packaging and dispersion, use of mineral additives and fillers and appropriate choice of material, concrete with low cement content and high strength was obtained, with relative consumption of binder materials below $5 \mathrm{~kg} / \mathrm{m}^{3}$ to produce $1 \mathrm{MPa}$ compressive strength. Various durability parameters were evaluated based on tests such water absorption by immersion, water absorption by capillarity, permeability, abrasion, corrosion potential and carbonation. The results indicate that the low cement consumption concretes may have achieved comparable or superior durability to concrete usually regarded as good performance. It was observed that the durability is dependent on the type of cement used and that durability should be assessed specifically with regard to the type of aggressive action that the concrete will be exposed.

Keywords: High resistance concrete. Low Portland cement content. Durability. Carbonation. Abrasion. Corrosion potential. Particle packaging. 
Figura 1 - Evolução do consumo de cimento. Fonte: adaptada de SNIC (2009). 7

Figura 2 - Representação esquemática da hidratação do cimento Portland comum, baseado na liberação de calor. Fonte: adaptada de Zampieri (1989).

Figura 3 - Desenvolvimento de calor de hidratação em concretos de diferentes espessuras, executados com mesmo teor de cimento Portland comum (esquerda) e cimento de alto forno (direita). Fonte: adaptada de VDZ (2008).

Figura 4 - Desenvolvimento de temperatura em concretos com 3,0 $\mathrm{m}$ de espessura e diferentes consumos de cimento Portland comum. Fonte: adaptada de Gajda e Alsamsam (2006).

Figura 5 - Evolução da retração plástica com o tempo para pasta de cimento, argamassa e concretos com diferentes teores de cimento. Fonte: L'Hermite (1960) apud Neville (1982). 18

Figura 6 - Influência do consumo de cimento na retração e fluência do concreto para relação água/cimento constante. Fonte: adaptada de Mehta e Monteiro (2008).

Figura 7 - Influência da relação água/cimento e do teor de agregado na retração por secagem. Fonte: adaptada de Ödman (1986) apud Neville (1982). 20

Figura 8 - llustração do efeito Parede. Fonte: Scrivener, Crumbie e Laugesen (2004). 29

Figura 9 - Relação de consumo de água e dimensão do agregado graúdo. Fonte: Mehta e Monteiro (2008).

Figura 10 - Idealização do comportamento de agregados com diferentes interfaces devido à exsudação interna. Fonte: Liborio (2003)... 36

Figura 11 - Diversas curvas granulométricas ideais. Fonte: Pereira (2010).

Figura 12 - Influência do tipo de cimento na resistência. Fonte: adaptada de Mehta e Monteiro (2008).

Figura 13 - Vida útil baseada no fenômeno da corrosão das armaduras em estruturas de concreto armado. Fonte: adaptada de Helene (1993). 52

Figura 14 - Causas físicas da deterioração do concreto. Fonte: Mehta e Gerwick (1982) apud Mehta e Monteiro (2008).

Figura 15 - Causas químicas da deterioração do concreto. Fonte: Mehta e Gerwick (1982) apud Mehta e Monteiro (2008).

Figura 16 - Representação esquemática de célula de corrosão eletroquímica no concreto armado. Fonte: Silva (2006).

Figura 17 - Relação entre desgaste à abrasão e resistência do concreto. Fonte: adaptada Naik, Singh e Hossain (1995).

Figura 18 - Curva granulométrica do fíler SM500, obtida em ensaio de sedimentação. Fonte: Pereira (2010).

Figura 19 - Empacotamento de agregados graúdos, representado em termos de massa unitária compactada. 
Figura 20 - Empacotamento de agregados graúdos, representado em termos de índice de vazios.

Figura 21 - Ensaio de miniabatimento de tronco de cone. Mistura em argamassadeira de laboratório (esquerda); minitronco de cone preenchido e paquímetro sobre superfície de vidro nivelada (centro); medida do diâmetro da pasta espalhada (direita).

Figura 22 - Ensaios mecânicos: compressão (esquerda); módulo de elasticidade (centro); tração na flexão (direita).

Figura 23 - Sequência de ensaio de absorção por imersão: (a) secagem em estufa, (b) resfriamento em recipiente com sílica-gel, (c, d, e) imersão em três etapas, (f) medição da massa submersa com balança hidrostática.

Figura 24 - Ensaio de Absorção por capilaridade: corpos de prova sobre lâmina de água de $5 \mathrm{~mm}$ (esquerda); marcação externa do nível da água capilar (centro); corpo de prova rompido diametralmente para avaliação interna de umidade (direita).

Figura 25 - Ensaio de abrasão: corte dos corpos de prova a partir de uma placa (esquerda); corpo de prova com marcação de pontos de medida de espessura (centro); máquina de abrasão (direita)

Figura 26 - Ensaio de carbonatação acelerada: corpos de prova prismáticos com topos selados com parafina (esquerda); corpos de prova dispostos no interior da câmara (centro); aspecto geral da câmara, com porta, termômetro e manômetro externo (direita). 101

Figura 27 - Determinação da profundidade de carbonatação: extração de fatia (esquerda); aspersão de fenolftaleína (centro); montagem do sistema de fotografia (direita).

Figura 28 - Análise de imagem para determinação da profundidade de carbonatação. a) importação e ajuste da escala; b) delimitação de núcleo isento de carbonatação; c) delimitação das quatro regiões laterais; d) medição de áreas e profundidades. 103

Figura 29 - Dimensões do corpo de prova para ensaio de potencial de corrosão. 104

Figura 30 - Preparação das barras no ensaio de potencial de corrosão: limpeza das barras em solução ácida e banho de ultrassom (esquerda); montagem das barras parcialmente isoladas com fita isolante na fôrma (centro); corpo de prova moldado com duas barras imersas (direita).

Figura 31 - Medida de potencial de corrosão: eletrodos padrão em solução de sulfato de cobre saturada (esquerda); medição do potencial de corrosão com sistema todo conectado (centro); fase de imersão parcial dos corpos de prova em solução de $\mathrm{NaCl}$ a 3,5 \% (direita).

Figura 32 - Ensaio rápido de permeabilidade: placa de concreto com anéis de PVC fixados (esquerda); aparato montado sobre amostra de concreto, mostrando registros superior e lateral com funil, manômetro e micrômetro lateral (centro); vista lateral mostrando aparato comprimido contra o corpo de prova por meio de presilhas (direita).

Figura 33 - Massa unitária compactada e índice de vazios em ensaio de empacotamento de agregados graúdos.

Figura 34 - Índice de vazios resultante em ensaio de empacotamento dos agregados miúdos. 
Figura 36 - Ensaio de miniabatimento de tronco de cone com cimento CP V-ARI e aditivo Glenium ${ }^{\circledR} 160$ SCC.

Figura 37 - Ensaio de miniabatimento de tronco de cone com cimento CP III-40-RS e aditivo Glenium ${ }^{\circledR} 160$ SCC.

Figura 38 - Resistência à compressão aos 28 dias e consumos relativos de cimento e aglomerantes para os concretos auxiliares VAux1 a VAux5.

Figura 39 - Fração de volume ocupada pelos diversos tipos de materiais do concreto, em função do consumo de cimento.

Figura 40 - Materiais utilizados na dosagem dos concretos de baixo consumo de cimento.

Figura 41 - Distribuições granulométricas das areias e misturas................................... 119

Figura 42 - Aspecto dos concretos no estado fresco após ensaio de abatimento. ............. 125

Figura 43 - Aspecto do concreto fresco ao retirar uma porção com colher de pedreiro, indicando teor de argamassa adequado.

Figura 44 - Aspecto do concreto fresco, indicando bom acabamento após alisamento com colher de pedreiro.

Figura 45 - Massa específica do concreto na condição saturada com superfície seca...... 128

Figura 46 - Evolução da resistência à compressão com a idade dos concretos estudados 129 Figura 47 - Evolução do módulo de elasticidade com a idade dos concretos estudados... 132 Figura 48 - Relação entre consumo de aglomerantes e resistência à compressão aos 28 dias. Fonte: adaptada de Damineli et al. (2010), incluindo os resultados dos concretos desenvolvidos neste trabalho.

Figura 49 - Ensaio de secagem por até 12 dias para avaliação da dificuldade de eliminação da água em ensaios de absorção.

Figura 50 - Avaliação de umidade interna, com auxílio de filme de sílica-gel, após 3 dias de secagem do concreto a $105^{\circ} \mathrm{C}$.

Figura 51 - Absorção de água por imersão com tempos de secagem de 3 e 12 dias a $105{ }^{\circ} \mathrm{C}$ e cura do concreto por 63 dias.

Figura 52 - Índice de vazios por imersão com tempos de secagem de 3 e 12 dias a $105{ }^{\circ} \mathrm{C}$ e cura do concreto por 63 dias.

Figura 53 - Avaliação de nível da frente de capilaridade e presença de umidade interna antes do ensaio, para tempo de secagem de 3 dias.

Figura 54 - Avaliação de nível da frente de capilaridade e presença de umidade interna antes do ensaio, para tempo de secagem de 12 dias.

Figura 55 - Coeficiente de absorção capilar com tempos de secagem de 3 e 12 dias a 105

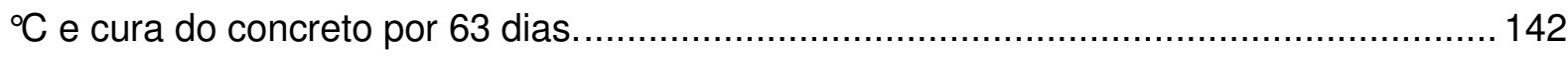

Figura 56 - Marcação externa da frente de avanço da capilaridade 142

Figura 57 - Abrasão para percurso de 500 m e 1000 m e classificação de pisos quanto à solicitação. 
Figura 58 - Correlação entre desgaste por abrasão e resistência à compressão ............... 145

Figura 59 - Resultado típico de ensaio de permeabilidade ............................................. 146

Figura 60 - Potencial de corrosão obtido ao longo de onze ciclos de exposição. ............... 152

Figura 61 - Diagrama de dosagem para os concretos convencionais com cimento CP V-ARI. 182

Figura 62 - Diagrama de dosagem para os concretos convencionais com cimento CP III-40-

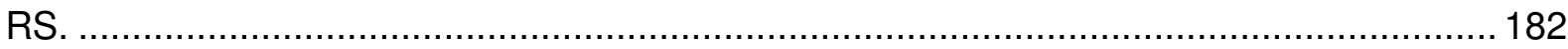

Figura 63 - Evolução da carbonatação no concreto V280 .............................................. 183

Figura 64 - Evolução da carbonatação no concreto V200 ............................................... 183

Figura 65 - Evolução da carbonatação no concreto VR4 ….......................................... 184

Figura 66 - Evolução da carbonatação no concreto III280 ............................................. 184

Figura 67 - Evolução da carbonatação no concreto III210 ............................................ 185

Figura 68 - Evolução da carbonatação no concreto IIIR4 ........................................... 185 
Tabela 1 - Consumo de materiais, em kg, e custos de dois concretos, um convencional e outro aprimorado.

Tabela 2 - Relação entre tempo e profundidade de hidratação de partículas de cimento Portland, sob condições normais de cura.

Tabela 3 - Vida útil de estruturas segundo o Eurocode 0.

Tabela 4 - Classes de agressividade ambiental e exigências de projeto conforme ABNT NBR 12.655:2006.

Tabela 5 - Recomendações de Lobo Carneiro para relação água/cimento em diferentes condições de agressividade.

Tabela 6 - Relação entre Absorção de água e Índice de vazios com a qualidade de concreto

Tabela 7 - Avaliação da corrosão por meio do potencial de corrosão (diferenças de potencial em $\mathrm{mV}$ )

Tabela 8 - Classificação de níveis de solicitação de abrasão.

Tabela 9 - Características físicas, químicas e mecânicas dos cimentos utilizados.

Tabela 10 - Caracterização física dos agregados miúdos. 83

Tabela 11 - Caracterização física dos agregados graúdos.

Tabela 12 - Consumos de materiais por $\mathrm{m}^{3}$ de concreto dos traços de baixo consumo de cimento $\left(\mathrm{kg} / \mathrm{m}^{3}\right)$.

Tabela 13 - Parâmetros dos traços de baixo consumo de cimento 123

Tabela 14 - Consumos de materiais por $\mathrm{m}^{3}$ de concreto dos traços de referência $\left(\mathrm{kg} / \mathrm{m}^{3}\right) .124$

Tabela 15 - Parâmetros dos traços de referência 124

Tabela 16 - Propriedades dos concretos no estado fresco 125

Tabela 17 - Resistência à tração na flexão, em MPa, dos concretos estudados. 130

Tabela 18 - Comparação entre os valores de resistência à tração na flexão, obtidos aos 28 dias, e os previstos pela ABNT NBR 6118:2003 com base na resistência à compressão.. 131 Tabela 19 - Comparação entre os valores de módulo de elasticidade obtido aos 28 dias e os previstos pela ABNT NBR 6118:2003 com base na resistência à compressão 132

Tabela 20 - Consumos de cimento, material cimentício, clínquer e emissão de $\mathrm{CO}_{2}$ para os seis traços analisados $\left(\mathrm{kg} / \mathrm{m}^{3}\right)$..... 133

Tabela 21 - Consumos de cimento, material cimentício, clínquer e emissão de $\mathrm{CO}_{2}$ para os seis traços analisados relativos à resistência à compressão aos 28 dias $\left(\mathrm{kg} \cdot \mathrm{m}^{-3} \cdot \mathrm{MPa}^{-1}\right)$.. 133 Tabela 22 - Altura $(\mathrm{cm})$ da frente de avanço da capilaridade para tempos de secagem de 3 e 12 dias.

Tabela 23 - Valores limites de coeficiente de permeabilidade determinados em ensaio de permeabilidade superficial rápida (Coeficiente de permeabilidade $\times 10^{-12} \mathrm{~m} / \mathrm{s}$ )..... 
Tabela 24 - Profundidades médias, máximas e mínimas da frente de carbonatação $(\mathrm{mm})$ para tempos de exposição até 96 dias.

Tabela 25 - Coeficiente de carbonatação $\left(\mathrm{mm}^{-\mathrm{dia}^{-1 / 2}}\right)$ baseado nos resultados até 56 dias de exposição

Tabela 26 - Estimativa de profundidade de carbonatação, em $\mathrm{mm}$, para a vida útil de 50 anos, equivalente a 100 dias de ensaio acelerado, baseado em resultados de Silva (2007)

Tabela 27 - Custos unitários dos materiais empregados $(\mathrm{R} \$ / \mathrm{kg})$.................................. 154

Tabela 28 - Custos dos materiais dos traços desenvolvidos .......................................... 154

Tabela 29 - Resistências à compressão, em MPa, dos corpos de prova dos concretos definitivos

Tabela 30 - Resistências à tração, em MPa, na flexão dos corpos de prova dos concretos definitivos

Tabela 31 - Módulos de elasticidade, em GPa, dos corpos de prova dos concretos definitivos

Tabela 32 - Consumo de materiais, em kg, dos traços auxiliares executados com cimento CP V-ARI

Tabela 33 - Parâmetros dos traços auxiliares executados com cimento CP V-ARI . 180

Tabela 34 - Consumo de materiais, em kg, dos traços auxiliares executados com cimento CP III-40-RS.

Tabela 35 - Parâmetros dos traços auxiliares executados com cimento CP III-40-RS. 


\section{LISTA DE ABREVIATURAS E SIGLAS}

AASHTO American Association of State Highway and Transportation Officials (EUA)

ABNT Associação Brasileira de Normas Técnicas

$\mathrm{ACl} \quad$ American Concrete Institute (EUA)

ASTM American Society for Testing and Materials (EUA)

BSI British Standards Institution (Reino Unido)

$\mathrm{C}_{2} \mathrm{~S} \quad$ Silicato Dicálcico ou belita.

$\mathrm{C}_{3} \mathrm{~A} \quad$ Aluminato Tricálcico ou aluminato.

$\mathrm{C}_{3} \mathrm{~S} \quad$ Silicato Tricálcico ou alita.

$\mathrm{C}_{4} \mathrm{AF} \quad$ Ferrroaluminato Tetracálcico.

$\mathrm{CaCO}_{3} \quad$ Carbonato de Cálcio.

$\mathrm{Ca}(\mathrm{OH})_{2} \quad$ Portlandita ou Hidróxido de Cálcio.

CAA Concreto autoadensável

$\mathrm{CaO} \quad$ Óxido de Cálcio

CAD Concreto de alto desempenho

CEB Comité Euro-International du Béton (Europa)

CEMBUREAU European Cement Association (Europa)

CEN Comité Européen de Normalisation (Europa)

$\mathrm{CH} \quad$ Hidróxido de Cálcio ou portlandita.

CP Cimento Portland

CP V-ARI Cimento Portland de alta resistência inicial

CP III Cimento Portland de alto-forno

C-S-H Silicato de Cálcio Hidratado.

CSI Cement Sustainability Initiative

DIN Deutsches Institut für Normung (Alemanha)

DNIT Departamento Nacional de Infraestrutura de Transportes

EESC Escola de Engenharia de São Carlos

FIB Fédération Internationale du Béton.

IBRACON Instituto Brasileiro do Concreto

IEA Agência Internacional de Energia

IPCC Painel Intergovernamental de Mudanças Climáticas

INT Instituto Nacional de Tecnologia

I.V. Índice de Vazios

LMABC Laboratório de Materiais Avançados à Base de Cimento

MUC Massa unitária compactada

$\mathrm{NaCl} \quad$ Cloreto de Sódio 
NIST National Institute of Standards and Technology (EUA)

NBR Norma Brasileira Registrada

NM Norma Mercosur

RAA Reação álcalis-agregado

RILEM Réunion Internationale des Laboratoires et Experts des Matériaux

RS Resistente a sulfatos

SA Sílica ativa

SET Departamento de Engenharia de Estruturas da EESC

SI Sistema Internacional de Unidades

SNIC Sindicato Nacional da Indústria do Cimento

SSS (condição) saturada superfície seca

SP Superplastificante

TSO The Highways Agency (Reino Unido)

USACE US Army Corps of Engineers (EUA)

USP Universidade de São Paulo

VDZ Verein Deutscher Zementwerke (Alemanha)

VUP Vida útil de projeto 


\section{LISTA DE SÍMBOLOS}

$\begin{array}{ll}\mathrm{a} / \mathrm{c} & \text { (relação) água/cimento } \\ \mathrm{a} / \mathrm{agl} & \text { (relação) água/aglomerantes } \\ \mathrm{t} & \text { tonelada } \\ \mathrm{bi} & \text { Binder intensity (consumo de aglomerantes em relação à resistência à } \\ & \text { compressão aos } 28 \text { dias) } \\ \mathrm{ci} & \mathrm{CO}_{2} \text { intensity (emissão de } \mathrm{CO}_{2} \text { do concreto em relação à resistência à } \\ & \text { compressão aos } 28 \text { dias) } \\ \mathrm{f}_{\mathrm{c}} & \text { resistência à compressão } \\ \mathrm{K}_{\mathrm{p}} & \text { coeficiente de permeabilidade } \\ \mathrm{N} . D . & \text { não definível }\end{array}$




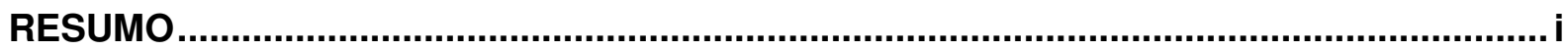

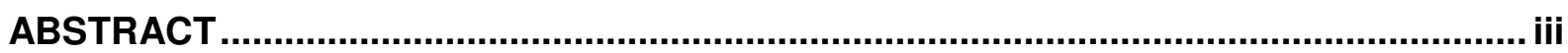

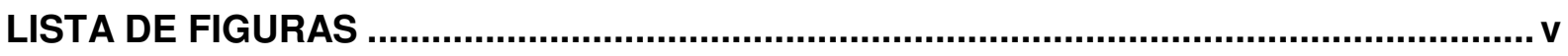

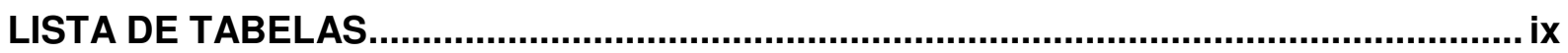

LISTA DE ABREVIATURAS E SIGLAS .............................................................................

LISTA DE SÍMBOLOS ........................................................................................... xiii

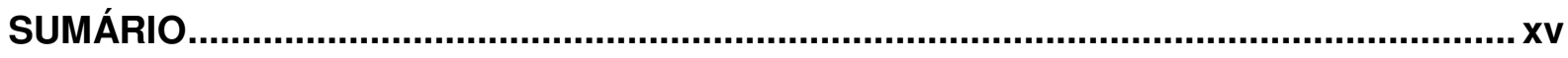

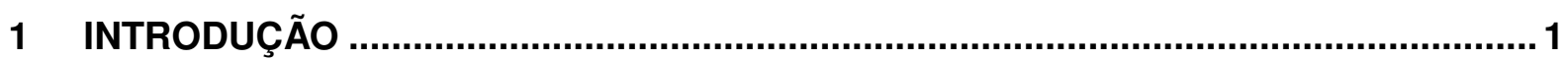

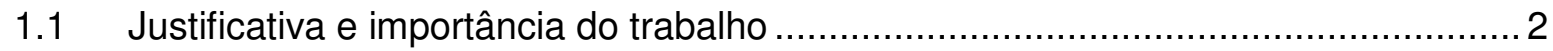

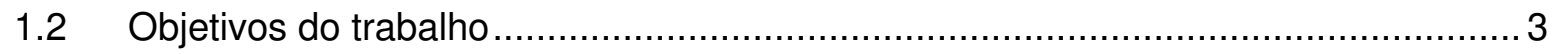

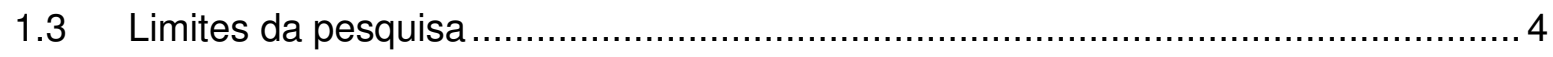

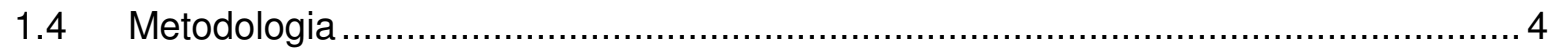

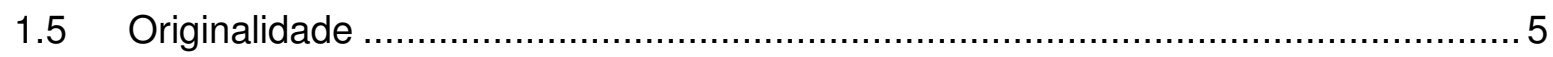

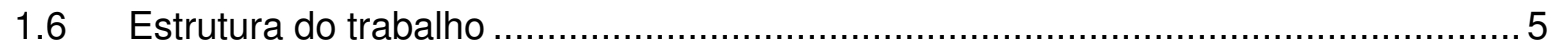

2 CONCRETOS COM BAIXO CONSUMO DE CIMENTO PORTLAND ............................. 7

2.1 Mercado do cimento e sustentabilidade .............................................................. 7

2.2 Vantagens decorrentes do baixo consumo de cimento ....................................... 12

2.3 Indicadores de baixo consumo de cimento ...................................................... 22

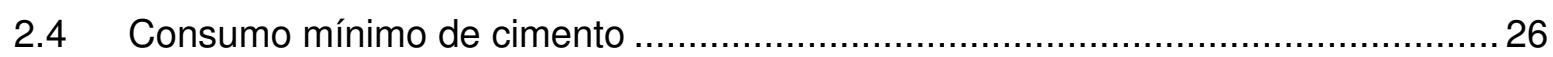

2.5 Produção de concreto de alta resistência com baixo consumo de cimento.............27

2.5.1 Redução do fator água/cimento ........................................................... 31

2.5.2 Melhoria da zona de interface e refinamento da estrutura de poros................ 33

2.5.3 Escolha adequada dos agregados.......................................................... 35

2.5.4 Máximo preenchimento do volume do concreto pelos agregados.................... 37

2.5.5 Procedimento e eficiência da mistura ......................................................... 43

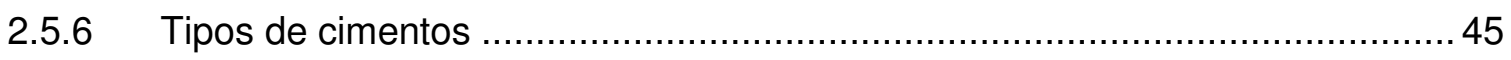

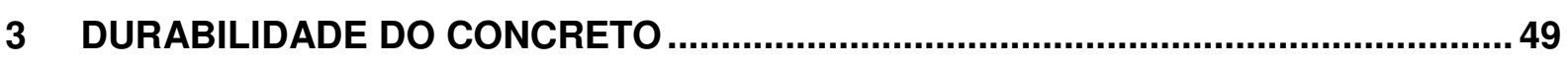

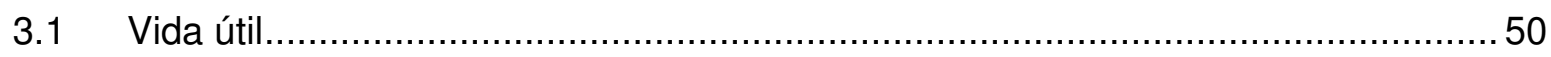

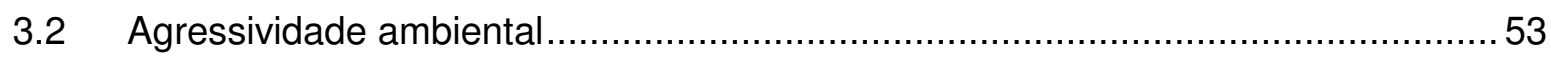

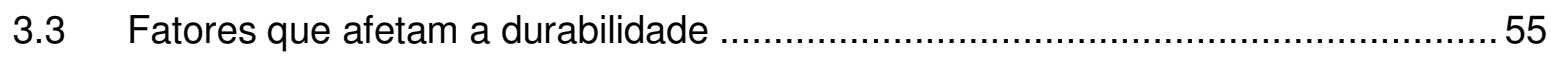

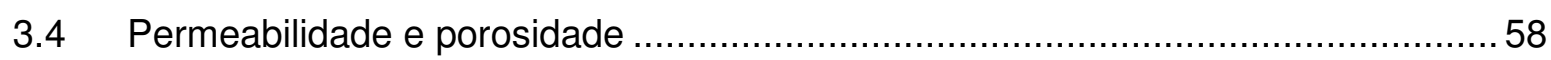

3.5 Ação de cloretos e corrosão da armadura .................................................. 61

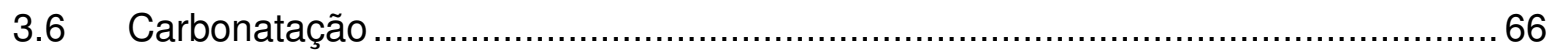

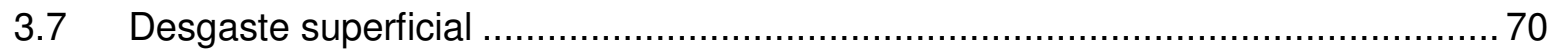




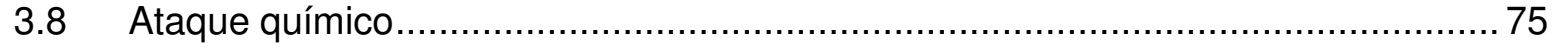

3.9 Concretos e estruturas de alto desempenho..................................................... 76

4 MATERIAIS UTILIZADOS E METODOLOGIA EXPERIMENTAL ................................. 79

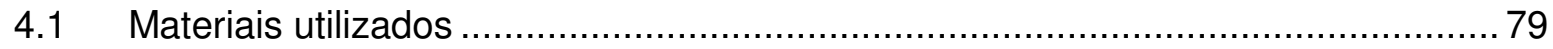

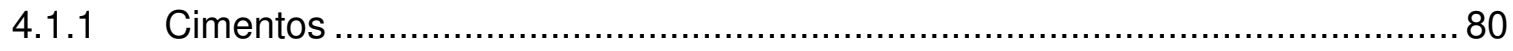

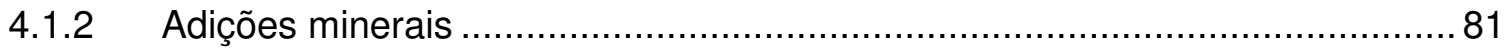

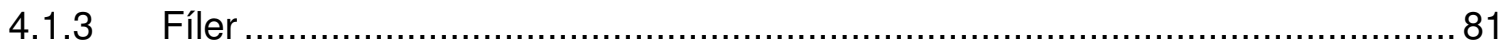

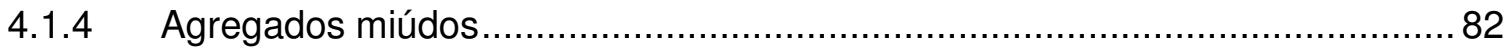

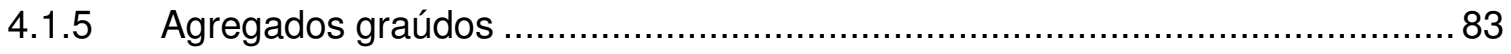

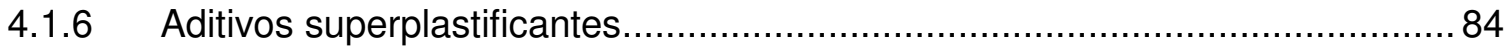

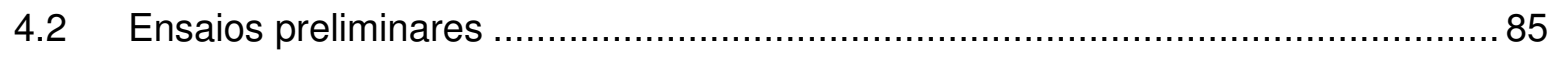

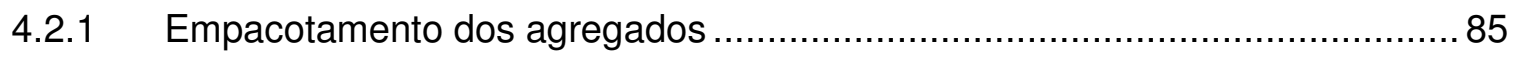

4.2.2 Avaliação dos aditivos ................................................................. 88

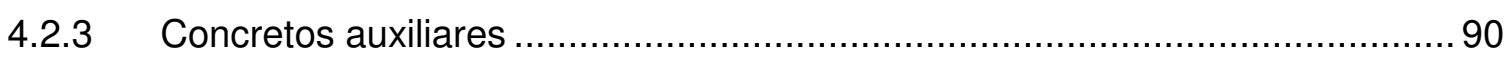

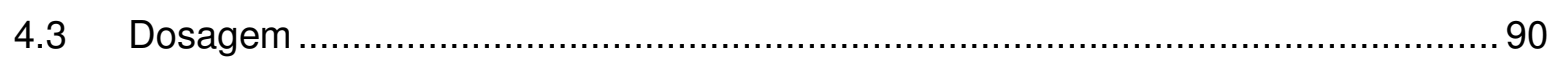

4.3.1 Concretos com baixo consumo de cimento …........................................ 91

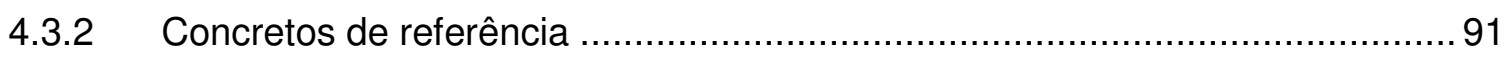

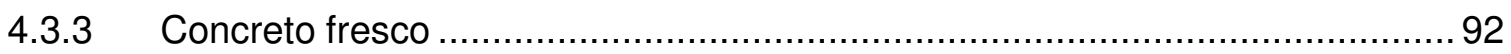

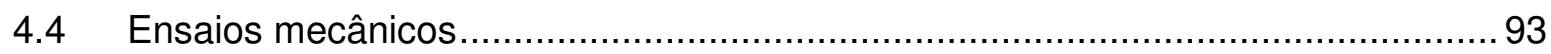

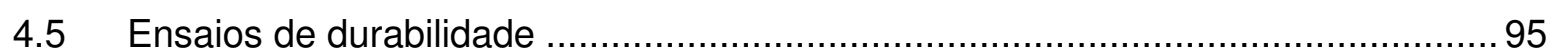

4.5.1 Absorção de água por imersão ............................................................ 95

4.5.2 Absorção de água por capilaridade ....................................................... 96

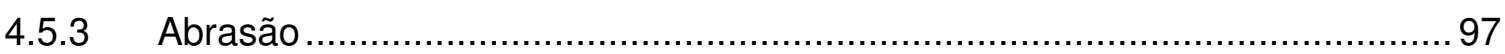

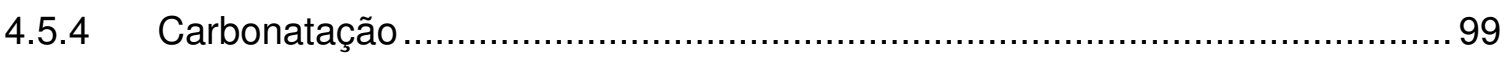

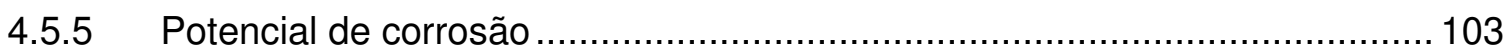

4.5.6 Permeabilidade................................................................................. 106

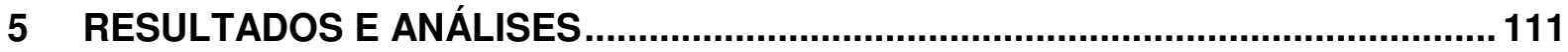

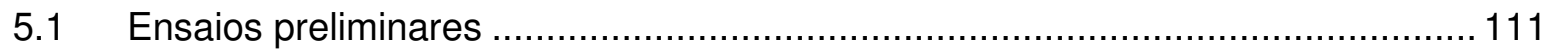

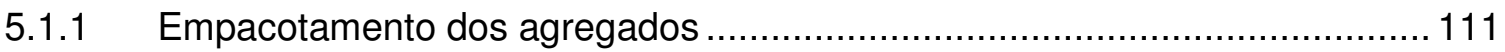

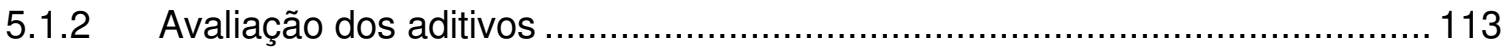

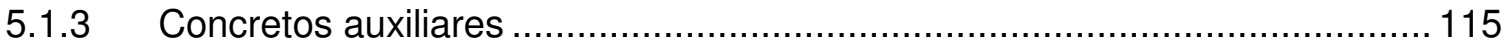

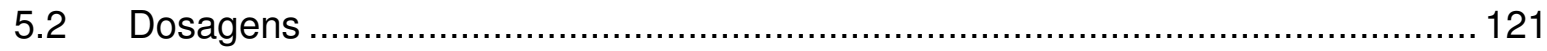

5.2.1 Convenção de nomenclatura e representação gráfica ................................ 121

5.2.2 Traços de baixo consumo de cimento ..................................................... 121

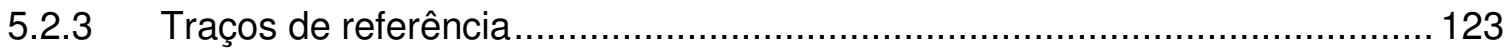

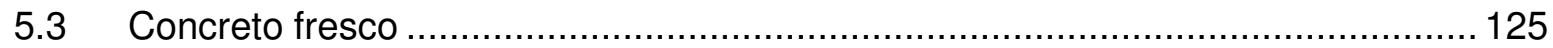


5.4 Ensaios físicos e mecânicos do concreto endurecido ….................................... 127

5.4.1 Massa específica do concreto saturado........................................................ 128

5.4 .2 Resistência à compressão ............................................................. 128

5.4.3 Resistência à tração na flexão ......................................................... 130

5.4.4 Módulo de elasticidade .................................................................. 131

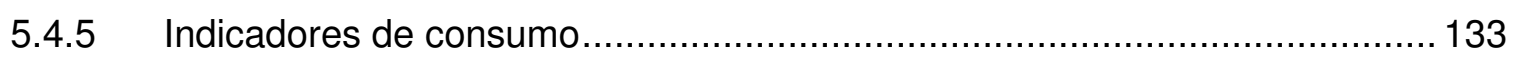

5.5 Ensaios de durabilidade do concreto endurecido......................................... 134

5.5.1 Absorção de água por imersão ........................................................ 135

5.5.2 Absorção de água por capilaridade ....................................................... 139

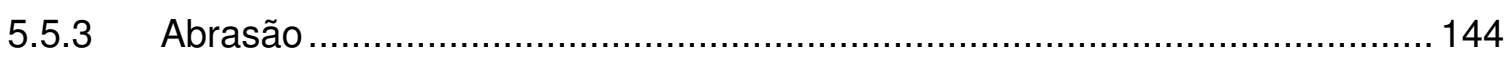

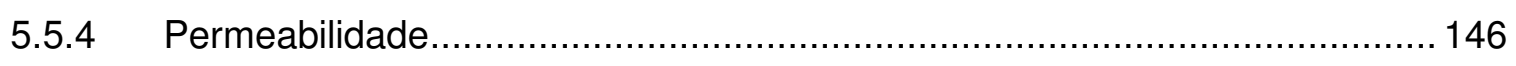

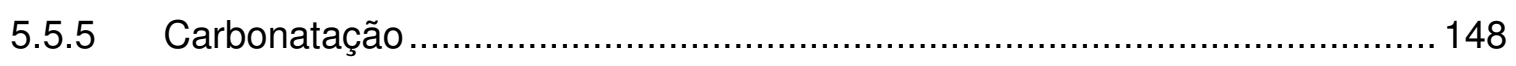

5.5.6 Potencial de corrosão .................................................................. 151

5.6 Avaliação de viabilidade econômica ........................................................... 154

6 CONCLUSÃO E CONSIDERAÇÕES FINAIS ....................................................... 157

6.1 Sugestões para prosseguimento da pesquisa ............................................. 163

REFERÊNCIAS BIBLIOGRÁFICAS...................................................................... 165

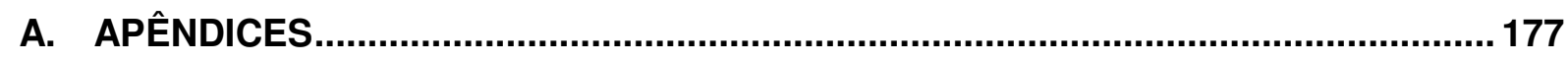

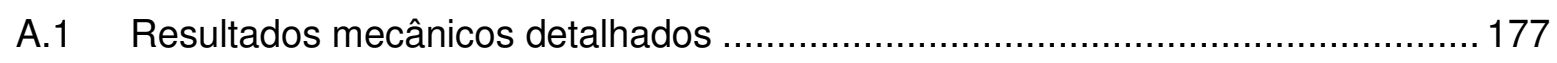

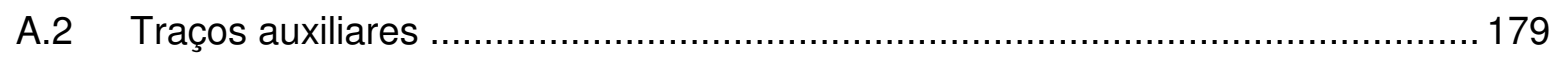

A.3 Diagramas de dosagem dos concretos auxiliares convencionais....................... 182

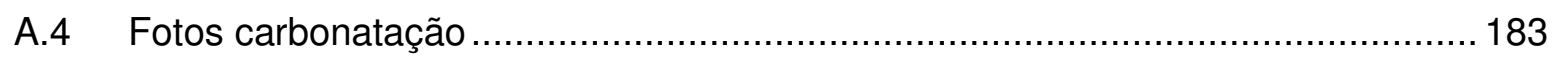




\section{INTRODUÇÃO}

O concreto, da forma como conhecemos hoje, surgiu com o advento do cimento Portland na primeira metade do século XIX. Em pouco tempo, assumiu o posto de principal material de construção e mais consumido material fabricado pelo homem, estimando-se atualmente consumo anual de cerca de 25 bilhões de toneladas ${ }^{1}$, aproximadamente 10 bilhões de metros cúbicos (CSI, 2009a). Apenas a água tem maior consumo. A importância do concreto pode ser analisada pela vasta presença em quase todo tipo de instalação humana na atualidade, desde simples calçadas até em rodovias, de passarelas de pedestres a pontes quilométricas, de habitações térreas unifamiliares aos maiores arranhacéus, de mobiliário urbano às maiores barragens, de atracadouros a plataformas flutuantes e instalações off-shore. Seja na habitação, no transporte terrestre, aéreo, fluvial e marítimo, na geração de energia em diversas formas, na armazenagem de materiais e resíduos, na expressão cultural e artística, hoje não é mais possível imaginar-se o mundo sem o concreto.

A facilidade de produção, liberdade na escolha da forma e relativo baixo custo comparado com outros materiais estruturais, permitiram a ampla aplicação do concreto, tornando-o alvo de grande volume de estudos e pesquisas. Aos materiais básicos, gradualmente foram adicionados outros, como as adições minerais, aditivos, fibras e materiais especiais. A incorporação de resíduos de diversas origens também tem sido amplamente estudada. O comportamento do concreto, nas suas diversas fases de vida, é avaliado tanto do ponto de vista estrutural macroscópico, como do ponto de vista microscópico. Todas estas investigações procuram desvendar os mistérios que se escondem atrás do comportamento do cimento Portland e dos produtos baseados nele, e podem ser sintetizadas sob o nome de "tecnologia do cimento e do concreto".

\footnotetext{
${ }^{1}$ As estimativas variam consideravelmente entre diversas fontes. Enquanto há estatísticas precisas sobre a produção de cimento, o mesmo não é possível para a produção de concreto. A fonte citada estima que o consumo de cimento corresponda a 8 a $12 \%$ do concreto, em peso. Localmente o consumo pode ser maior se outros materiais cimentícios forem utilizados ou menores se mais cimento for utilizado para outras aplicações. Estimativas mais conservadoras consideram proporções de $15 \%$ (JOHN, 2003), o que corresponderia a um consumo de concreto de cerca de sete bilhões de metros cúbicos anuais.
} 


\subsection{Justificativa e importância do trabalho}

A aplicação consciente dos recursos naturais disponíveis é um tema atual e necessário. Para que as futuras gerações possam existir e se desenvolver, a atual geração deve gerenciar da maneira mais responsável possível os recursos à disposição. Estudos neste sentido são necessários, visando o emprego de menores níveis de consumo de recursos escassos e o aumento da durabilidade dos produtos fabricados.

O crescimento econômico experimentado por países em desenvolvimento tem elevado continuamente o consumo mundial de cimento, com destaque para a China que hoje responde sozinha por mais da metade da produção mundial de cimento (CEMBUREAU, 2010). O necessário aumento de fabricação de clínquer gera alguns problemas de sustentabilidade ambiental e do negócio do cimento. A redução da longevidade das atuais jazidas de matérias primas, os aumentos de emissão de $\mathrm{CO}_{2} \mathrm{e}$ consumo de energia e maiores custos de distribuição estão entre os principais problemas enfrentados.

Mehta (2008), em palestra proferida no congresso anual do IBRACON, indicou três ferramentas na direção da sustentabilidade na indústria do cimento: redução do consumo de concreto nas estruturas, redução do consumo de cimento no concreto e redução do teor de clínquer no cimento.

Vários estudos desenvolvidos pelo LMABC (Laboratório de Materiais Avançados a Base de Cimento) do SET/EESC apontam na mesma direção indicada por Mehta, tendo-se verificado a viabilidade mecânica de produzir concretos com baixo consumo de cimento. Concretos com resistência mecânica acima de $60 \mathrm{MPa}$ foram obtidos com consumos de cimento abaixo de $300 \mathrm{~kg} / \mathrm{m}^{3}$.

A durabilidade do concreto foi correlacionada por muito tempo com a resistência, mas, devido ao progresso na tecnologia do cimento e do concreto, nos últimos tempos passou a ser possível obter boas resistências mesmo com concretos com relativamente alta relação água/cimento $(\mathrm{a} / \mathrm{c})$. A porosidade resultante prejudica a durabilidade, pois a maior permeabilidade aos agentes agressividades é o principal fator desencadeante de agressões (AÏTCIN, 2000).

Para Aïtcin (2000) os concretos duráveis que se fazem atualmente têm resistências à compressão da ordem de 60 a $100 \mathrm{MPa}$. O concreto de alto desempenho de amanhã conterá cada vez menos cimento Portland, cada vez mais materiais cimentícios suplementares ou mesmo adição de fíler. Esta substituição é vantajosa do ponto de vista 
econômico, reológico e de desenvolvimento de calor. O que se pode perder em termos de propriedades aglomerantes iniciais (24 horas) pode ser compensado pela redução adicional da relação água/aglomerante (a/agl). A redução de cimento e sua substituição por materiais cimentícios menos reativos podem resultar em consumo inferior de superplastificante para a mesma trabalhabilidade, de forma que uma redução significativa no custo do metro cúbico de concreto de alto desempenho pode ser obtida (AÏTCIN, 2000).

As dúvidas sobre a durabilidade de concretos com baixo consumo de cimento e as visões de futuro citadas justificam a avaliação da durabilidade destes concretos. Os fatores que devem ser observados na sua obtenção necessitam ser estabelecidos. Possivelmente novos limites para consumos mínimos de cimento possam ser estabelecidos, baseados não apenas em critério de resistência, mas, sobretudo, de desempenho. A viabilidade técnica precisa ser acompanhada de viabilidade econômica. Um bom desempenho financeiro não se restringe apenas à diminuição dos custos iniciais, mas, também, à obtenção de bom desempenho e durabilidade para reduzir os custos de manutenção e aumentar a vida útil.

\subsection{Objetivos do trabalho}

Este trabalho tem como objetivo geral avaliar aspectos de durabilidade de concretos elaborados com baixo teor de cimento.

Como objetivos específicos citam-se:

- Obter concretos de baixo consumo de cimento;

- Obter concretos de referência baseado em critérios de durabilidade especificados por normas de concreto vigentes;

- Avaliar as principais características mecânicas destes concretos em idades de 7 a 91 dias. Correlacionar a evolução da resistência à compressão ao longo deste tempo com o previsto pela ABNT NBR 6118:2003. Verificar também a validade das fórmulas da norma que correlacionam o módulo de elasticidade e resistência à tração na flexão com a resistência à compressão. O estudo da evolução do módulo de elasticidade se justifica pela necessidade de atendimento de valores mínimos quando da retirada de fôrmas e escoramentos;

- Avaliar diversos parâmetros de durabilidade;

- Verificar a consequência, em relação à durabilidade, de consumo de cimento abaixo dos limites fixados por normas nacionais e internacionais; 
- Avaliar a influência de tipos diferentes de cimento, com variado teor de clínquer;

- Avaliar limites práticos e dificuldades de produção de concretos com baixos consumos de cimento.

\subsection{Limites da pesquisa}

O tema durabilidade é muito amplo, não havendo ensaios ou medidas que possam de maneira simples e fácil concluir a respeito de quão durável é determinado concreto. Mesmo que um concreto seja durável em relação a um tipo de agressão, pode não ser em relação a outro.

Desta maneira, o trabalho limita-se à avaliação de apenas dois tipos de cimento, sendo para cada tipo elaborados dois concretos com diferentes níveis de consumo, um dentro dos limites atuais das normas vigentes e outro abaixo destes limites, sendo, porém, ambos considerados de baixo consumo de cimento Portland em função do desempenho obtido.

Para avaliação de quesitos de durabilidade existe grande quantidade de ensaios, propostos por diversos pesquisadores, tendo cada um as suas aplicações, limitações e críticas. Dentre esta diversidade, optou-se por avaliar os principais aspectos, focando-se em avaliar parâmetros relativos à permeabilidade, porosidade, corrosão, carbonatação e desgaste superficial.

\subsection{Metodologia}

O trabalho se desenvolve a partir de uma revisão bibliográfica sobre aspectos de consumo de cimento e sobre aspectos de durabilidade do concreto normal e de alto desempenho. A seguir um programa experimental visa atingir os objetivos citados nesta introdução.

O programa experimental apresenta inicialmente a caracterização dos materiais empregados e a seguir as etapas seguidas para obtenção dos concretos de baixo consumo de cimento e dos concretos de referência.

Os ensaios de caracterização mecânica empregados compreendem a determinação da resistência à compressão, resistência à tração na flexão e módulo de elasticidade.

Para avaliar a durabilidade dos concretos obtidos foram empregados métodos diversos, de modo a abranger mecanismos diversos de agressão. Estudou-se assim a 
absorção de água por imersão e capilaridade, a abrasão, permeabilidade por meio de um ensaio rápido recomendado para uso no campo, carbonatação acelerada e potencial de corrosão.

\subsection{Originalidade}

A originalidade deste trabalho está inicialmente nos baixíssimos níveis de consumo de cimento Portland obtidos, ressaltando que como baixo consumo entende-se não somente pequena quantidade absoluta de cimento, mas principalmente alta eficiência, resultando em baixo consumo relativo (relação consumo/resistência). Comparando com os dados coletados em vasta pesquisa de concretos executados no Brasil e no Mundo (DAMINELI et al. 2010), pode-se dizer que os resultados estão certamente entre os mais baixos níveis de consumo.

Embora haja indicativos de que consumos absolutos mais baixos que os atualmente sugeridos pelas normas vigentes possam se utilizados, ainda há dúvidas sobre o comportamento e durabilidade. Neste sentido este trabalho busca oferecer algumas respostas adicionais para elucidar esta indagação.

Ainda como contribuição à experimentação direcionada à durabilidade, analisa-se um problema que pode ter comumente ocorrido com muitos pesquisadores em ensaios de porosidade e carbonatação com concretos de baixa permeabilidade. Mostra-se que procedimentos normatizados, e amplamente utilizados, podem resultar em valores distorcidos, devido à dificuldade de eliminação da água através da estrutura de poros muito fechada.

\subsection{Estrutura do trabalho}

Este trabalho está organizado em seis capítulos, além das referências bibliográficas e dos apêndices.

O Capítulo 1 compreende esta introdução onde se estabeleceu as motivações para o trabalho além dos objetivos que se pretende alcançar. A metodologia a ser empregada e os fatores limitantes, bem como os pontos originais desta pesquisa, são brevemente comentados.

A revisão bibliográfica do Capítulo 2 aborda a situação atual de consumo de cimento no Brasil e no mundo e como isto impacta na sustentabilidade da indústria do cimento. 
Citam-se dados a respeito de consumo de cimento, energia necessária para produção, emissão de $\mathrm{CO}_{2}$ e teores usuais de clínquer no cimento. Características técnicas vantajosas devido a um menor consumo de cimento são analisadas, bem como diversos indicadores de baixo consumo e limites mínimos impostos por convenções normativas. Por fim discorre-se sobre seis estratégias que podem ser empregadas para obter menores consumos de cimento.

No Capítulo 3 a revisão bibliográfica trata de durabilidade, estabelecendo inicialmente definições a respeito de durabilidade, vida útil, agressividade ambiental e os fatores e agentes que levam à degradação. Posteriormente analisam-se mais detalhadamente algumas propriedades dos concretos e mecanismos de degradação relacionados com a durabilidade do concreto e os ensaios comumente aplicados.

O Capítulo 4 apresenta os materiais empregados, com suas principais características. Também relata detalhadamente os ensaios realizados. Os procedimentos dividem-se em três etapas, inicialmente os ensaios prévios realizados para estabelecer as dosagens dos concretos de baixo consumo e os concretos de referência; em seguida a confecção dos concretos e suas características no estado fresco; e por fim a avaliação no estado endurecido por meio de ensaios mecânicos e de durabilidade. São avaliados a resistência à compressão, resistência à tração na flexão, módulo de elasticidade, absorção de água por imersão e capilaridade, abrasão, carbonatação, potencial de corrosão e permeabilidade.

No Capítulo 5 faz-se a apresentação e discussão dos resultados obtidos. Buscou-se, além de comparar os concretos com baixo consumo de cimento com os concretos de referência, realizar comparações com resultados similares encontrados na literatura técnica, de acordo com a revisão bibliográfica realizada. Por fim, uma rápida análise de custos visa indicar a viabilidade econômica destes concretos de baixo consumo de cimento.

O Capítulo 6 conclui com uma síntese dos principais resultados obtidos e apresenta sugestões para aprofundamento e prosseguimento da pesquisa.

Por fim o trabalho apresenta ainda as Referências Bibliográficas e alguns Apêndices, onde são apresentados dados mais detalhados dos ensaios realizados e alguns registros fotográficos. 


\section{CONCRETOS COM BAIXO CONSUMO DE CIMENTO PORTLAND}

\subsection{Mercado do cimento e sustentabilidade}

De acordo com o Sindicato Nacional da Indústria do Cimento (SNIC, 2009) em 2008 a indústria brasileira de cimento produziu 52,0 milhões de toneladas de cimento, o que representa um aumento de $44 \%$ em relação à produção de 2004 , quando foram produzidas 36,0 milhões de toneladas. Nestes mesmos quatro anos o consumo mundial de cimento passou de 2.192 milhões para 2.837 milhões de toneladas, representando um aumento de $29 \%$. A taxa de crescimento brasileira, portanto, é superior à taxa de crescimento mundial.

Na Figura 1 é apresentada a evolução do consumo mundial e nos principais países em desenvolvimento. Os dados são apresentados percentualmente em relação aos consumos de 2002. Nota-se claramente uma tendência de crescimento contínua.

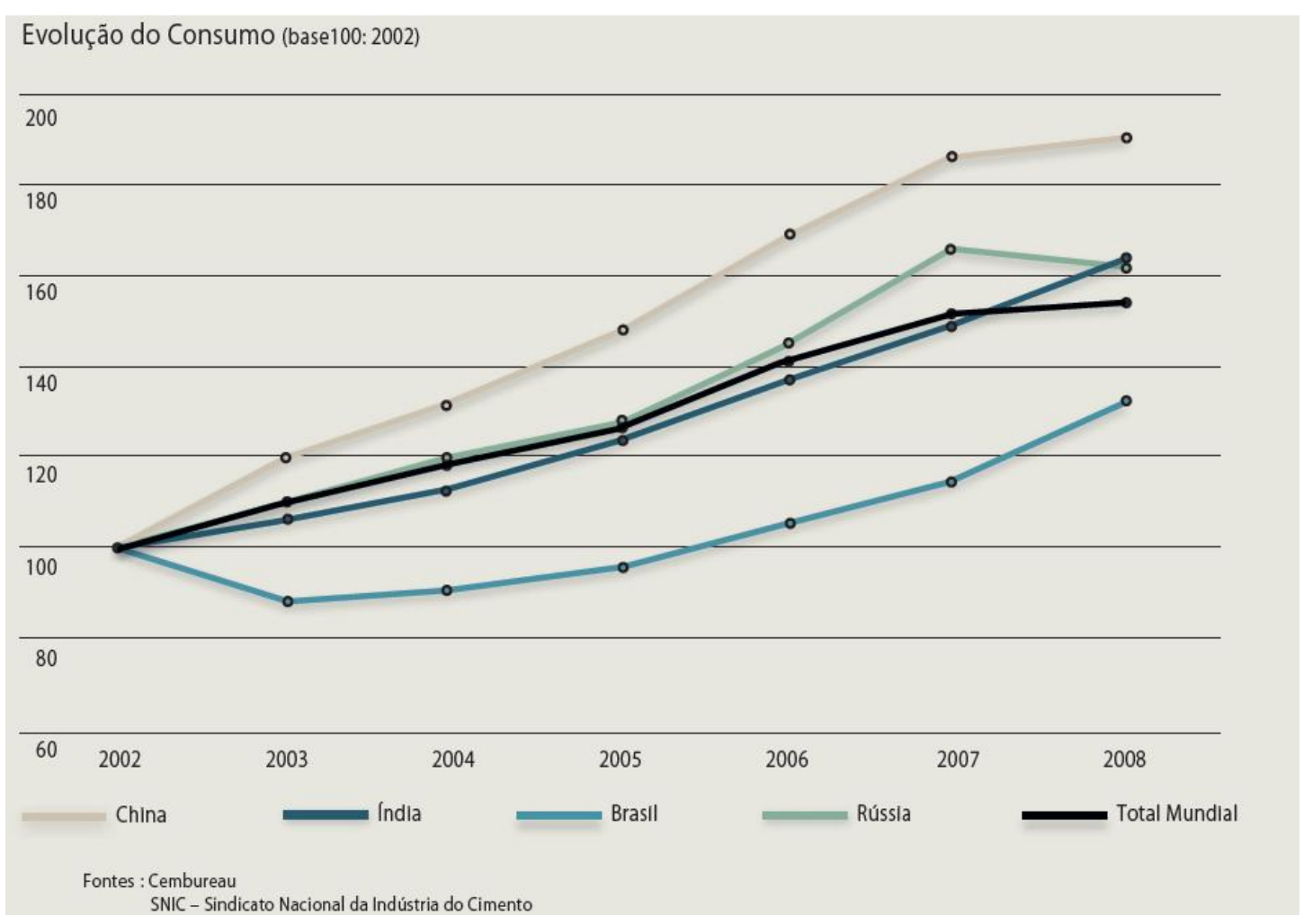

Figura 1 - Evolução do consumo de cimento. Fonte: adaptada de SNIC (2009).

O crescimento econômico é acompanhado pela necessidade de investimentos em infraestrutura e construções em geral, ocorrendo um aquecimento no mercado da 
construção civil. Por ser o principal material de construção, o concreto tem seu consumo aumentado proporcionalmente ao aquecimento da economia. O aumento de consumo de cimento ilustra este aumento de produção de concreto.

Müller e Harnisch (2008) estimam que até o ano de 2030, a continuidade de desenvolvimento das principais economias mundiais elevará o consumo de cimento para cerca de 5.000 milhões de toneladas/ano, um aumento de quase $80 \%$ em relação ao ano de 2008.

O relatório do Painel Intergovernamental de Mudanças Climáticas - IPCC - estima para 2030 uma produção de 5.251 a 6.517 milhões de toneladas de cimento por ano, para dois possíveis cenários de crescimento econômico, populacional e tecnológico (BERNSTEIN et al., 2008). Em média estima que a produção de cimento esteja crescendo 2,5 \% ao ano. Taxa semelhante é citada em EPE \& IDDRI (2008), que ainda aponta para maiores consumos em infraestrutura (crescimento de 3,3\%) e menores em edifícios (2,0 \%). Na Ásia é previsto $75 \%$ do consumo mundial. O consumo anual de cimento em 2050 deverá estar entre 4.933 e 5.719 milhões de toneladas.

Números mais conservadores são apresentados em estudos patrocinados por empresas de cimento. Em busca de um desenvolvimento sustentável, os objetivos destes estudos são obter informações estatísticas representativas acerca da evolução do setor e a performance de uso de energia e emissão de $\mathrm{CO}_{2}$ na produção de clínquer e cimento (CSI, 2009b). Os dados são obtidos atualmente de 844 instalações de cimento das empresas que fazem parte da iniciativa, o que representa cerca de $30 \%$ da produção mundial de cimento. Segundo a CSI (2009c) a estimativa para 2050 é de produção de 3.657 a 4.397 milhões de toneladas.

A Agência Internacional de Energia em seu relatório de cenários e estratégias até 2050 (IEA, 2008) prevê crescimento de produção de cimento de $84 \%$ de 2005 a 2050, o que totalizaria cerca de 4.330 milhões de toneladas.

Mesmo havendo prognósticos diferenciados, todas as estimativas apontam para um considerável aumento de consumo de cimento para as próximas décadas. As principais consequências deste aumento de consumo se refletem no aumento do consumo de energia e emissões de $\mathrm{CO}_{2}$, na necessidade de instalação de novas unidades industriais, na dificuldade de manter as fontes de matérias primas necessárias para a fabricação do cimento e em maior demanda de transporte para escoar a produção.

A produção de cimento é um processo altamente energético. A energia representa de 20 a $40 \%$ do custo de produção do cimento (IEA, 2008). A maior parte é consumida no 
aquecimento dos fornos e na moagem das matérias primas e do cimento. A IEA (2007) cita que a energia consumida pela indústria cimenteira representa $70 \%$ a $80 \%$ do consumo de energia de toda a indústria mineral não metálica, correspondendo a um total de 8,2 exajoules $^{2}$ anuais. A quantidade de energia térmica necessária para a produção de clínquer depende da eficiência do forno e do tipo de energia utilizada. Estimativas indicam consumos de energia térmica para produção do clínquer variando de 3,4 a 5,3 GJ/t, com média em 4,4 GJ/t (IEA, 2007). Previsões da indústria cimenteira para 2050 preveem redução de no máximo para 3,2 GJ/t (CSI, 2009c). Já o consumo de energia elétrica para produção do cimento, estimado atualmente pela indústria cimenteira em $111 \mathrm{kWh} / \mathrm{t}$, tem previsão de redução máxima para 92 GJ/t em 2050 (CSI, 2009c). Um aumento de produção anual de cimento de 2,5\%, o que equivale hoje a aproximadamente 75 milhões de toneladas de cimento no mundo, geraria um consumo adicional de energia elétrica de aproximadamente 7,3 bilhões de kWh por ano, o que representa cerca de $9 \%$ da produção da usina de Itaipu ${ }^{3}$. A energia térmica adicional anual é de cerca de 330 milhões de GJ, ou 52 milhões de barris de petróleo ${ }^{4}$, equivalente a cerca de $7 \%$ da produção anual dos campos de petróleo nacionais do Brasil ${ }^{5}$.

$\mathrm{O}$ aquecimento global relacionado às emissões de $\mathrm{CO}_{2}$ pelo homem atualmente é um tema polêmico, sendo debatido por cientistas, ambientalistas e políticos. Enquanto o relatório da Quarta Avaliação do Painel Intergovernamental de Mudanças Climáticas (IPCC, 2007) relaciona o aquecimento da terra com as emissões antropogênicas, isto é, causadas pela atividade humana, outros o relacionam com fatores naturais tais como atividade solar, albedo terrestre e correntes marítimas (MOLION, 2008). Não é intuito deste trabalho analisar ou julgar esta questão, nem criticar uma ou outra posição. Serão apenas citados dados a respeito das emissões de $\mathrm{CO}_{2}$ ligadas à produção de cimento e concreto, visando dar noção sobre o impacto que a produção de concretos com menor consumo de cimento pode ter sobre a emissão de gás carbônico.

A emissão de $\mathrm{CO}_{2}$ na produção de cimento é decorrente, sobretudo, da decomposição em óxidos dos carbonatos presentes no calcário. Este processo, denominado de calcinação, ocorre entre 700 e $900{ }^{\circ} \mathrm{C}$. Outra parcela significativa é oriunda da combustão de combustível para aquecer os fornos até à temperatura de cerca de $1450{ }^{\circ} \mathrm{C}$,

\footnotetext{
${ }^{2}$ Exajoules $=$ EJ. $1 \mathrm{EJ}=10^{18} \mathrm{~J}=10^{9} \mathrm{GJ}$.

3 A produção anual de Itaipu em 2009 foi de 91,7 bilhões de kWh (http://www.itaipu.gov.br/energia/geracao).

${ }^{4}$ Um BEP (Barril equivalente de petróleo) equivale a 6,383 GJ.

${ }^{5}$ A produção de petróleo dos campos nacionais atingiu 1,971 milhões de barris por dia em 2009, o que equivale a 719 bilhões de barris anuais (http://www.petrobras.com.br/rs2009/pt/relatorio-desustentabilidade/desempenho-operacional/exploracao-e-producao/)
} 
necessária para a produção de clínquer. Müller e Harnisch (2008) citam que cerca de 55 \% do total de emissões devem-se à decomposição do calcário e $40 \%$ devido à queima de combustível. A IEA (2008) reporta que $57 \%$ da emissão de $\mathrm{CO}_{2}$ é devido à calcinação, o que chega a representar $3,5 \%$ do total de $\mathrm{CO}_{2}$ emitido globalmente. $\mathrm{O}$ total de emissões, segundo Bernstein et al. (2008) e Worrell et al. (2001), chega a $5 \%$ do total de $\mathrm{CO}_{2}$ emitido pelo homem. Em 2003 estimou-se emissão de 1587 a 1697 milhões de toneladas de $\mathrm{CO}_{2}$, sendo cerca de metade devido à reação de calcinação e a outra metade devido à energia utilizada na produção (BERNSTEIN et al., 2008).

A CSI (2009b) estima que 60 \% das emissões diretas são devido à calcinação e o restante devido à queima de combustível. Além destes, mais $10 \%$ de emissões indiretas devem ser contabilizadas em função do consumo de energia elétrica.

Conforme a eficiência e tipo de processo de produção e tipo de energia utilizada, a emissão de $\mathrm{CO}_{2}$ varia entre 824 e $1152 \mathrm{~kg}$ por tonelada de clínquer (YAMAMOTO et al., 1997).

O teor de clínquer no cimento varia conforme o tipo de cimento, levando a uma ampla variação na emissão de $\mathrm{CO}_{2}$ dos cimentos. Josa et al. (2004) realizaram um levantamento de diversos cimentos na Europa e verificaram teores de clínquer entre 20 e $100 \%$, levando a uma faixa de emissão de $\mathrm{CO}_{2}$ entre 212 e $918 \mathrm{~kg}$ por tonelada de cimento. Segundo a IEA (2007) as emissões variam de 650 a $920 \mathrm{~kg}$ de $\mathrm{CO}_{2}$ por tonelada de cimento, com média ponderada de $830 \mathrm{~kg}$. A CSI (2009b) contabiliza $866 \mathrm{~kg}$ de $\mathrm{CO}_{2}$ por tonelada de clínquer e média de $679 \mathrm{~kg}$ de $\mathrm{CO}_{2}$ por tonelada de cimento.

Worrell et al. (2001) citam emissões de $\mathrm{CO}_{2}$ médias de $814 \mathrm{~kg}$ (222 kg de carbono) e Humphreys e Mahasenan (2002) de $870 \mathrm{~kg}$ por tonelada de cimento. Bernstein et al. (2008) citam também variações locais de $700 \mathrm{~kg}$ (Europa ocidental), $730 \mathrm{~kg}$ (Japão e Coréia do Sul), $900 \mathrm{~kg}$ (China), $930 \mathrm{~kg}$ (Índia) e $925 \mathrm{~kg}$ (EUA), diferenças principalmente devido à porcentagem de clínquer no cimento e eficiência energética, sendo estes dois itens os de maior potencial para permitir redução de emissões. O uso mais intensivo de cimento composto tem potencial de reduzir emissões em mais de $7 \%$. Atualmente o uso de cimentos compostos é alto na Europa continental e baixo nos EUA e UK. Nos EUA e China é prática comum adquirir cimento com maior teor de clínquer e substituir parte do cimento por adições durante a produção do concreto, prática rara em outros países (IEA, 2007).

Segundo a CSI (2009c) o prognóstico para o ano de 2050 é de se atingir emissões de 636 a $693 \mathrm{~kg}$ de $\mathrm{CO}_{2}$ por tonelada de cimento, gerando com isto 2.337 a 2.796 milhões de toneladas de $\mathrm{CO}_{2}$ anualmente. Estas estimativas são para cenários de baixa e alta 
demanda de cimento e com tecnologias e processos de produção comparáveis aos atuais. Redução maior no teor de clínquer, maior eficiência energética e uso de combustíveis alternativos poderiam reduzir as emissões para valores entre 352 e $426 \mathrm{~kg}$ por tonelada de cimento.

Várias medidas para reduzir a emissão de $\mathrm{CO}_{2}$ na indústria cimentícia podem ser sugeridas: redução do teor de clínquer, substituindo-o por adições minerais, aumento da eficiência energética e uso de combustíveis alternativos, tais como biocombustíveis ou resíduos (DAMINELI et al. 2010). Os dois primeiros itens combinados têm potencial de redução da emissão de $\mathrm{CO}_{2}$ em 30 \% (HUMPHREYS e MAHASENAN, 2002).

De maneira mais geral, considerando toda a indústria de construção com concreto, Mehta (2008) sugere redução em três níveis: menor consumo de concreto nas estruturas, menor consumo de cimento no concreto e menor consumo de clínquer no cimento. Aliando estas três ações seria possível obter redução de 40 a 50 \% no consumo de clínquer, cuja produção é o item principal de emissão de $\mathrm{CO}_{2}$. A implantação destas ações passa por inovações arquitetônicas, redução das seções estruturais, processos de cálculo estrutural mais refinado, aplicação de concreto mais durável, alteração da idade de referência para avaliação da resistência do concreto de 28 para 56 ou 91 dias, uso de aditivos químicos plastificantes, uso otimizado de tamanho e graduação dos agregados e substituição de clínquer por adições minerais em proporções de até $70 \%$.

Outra alternativa é a captura do $\mathrm{CO}_{2}$ durante o processo de fabricação e posterior armazenamento em estruturas geológicas estanques ou nos oceanos. Anderson e Newell (2004) estimam que seja possível desta forma reduzir as emissões de $\mathrm{CO}_{2}$ em 65 a $70 \%$, porém a um custo alto de 49 a 250 US\$ por tonelada de $\mathrm{CO}_{2}$. Atualmente o custo de fabricação do cimento varia de 80 a 136 US\$ por tonelada (JP MORGAN ${ }^{6}, 2009$, apud SNIC, 2009). Além de questionamentos sobre a garantia desta armazenagem, este processo levanta claras dúvidas a respeito da viabilidade econômica, uma vez que os custos com a mitigação poderiam ultrapassar o atual custo de fabricação do cimento.

O interessante é que as medidas de redução de consumo de cimento no concreto são medidas que possibilitam a redução de $\mathrm{CO}_{2}$ sem impactar muito no custo final do concreto, enquanto que para outras alternativas chega-se a estimar custos que poderiam dobrar o valor atual do cimento.

\footnotetext{
${ }^{6}$ JP MORGAN. Construction and Building Materials Sector. set. 2009.
} 
A taxa atual de clínquer é estimada pela IEA (2007) entre 70 e $95 \%$. Uma média mundial de 78 \% é citada em CSI (2009b). CSI (2009c) estima para 2050 uma taxa de 74 a 75 \% de clínquer no cimento, caso não sejam implantadas novas tecnologias. Mesmo com alterações não há perspectiva de que este valor fique abaixo de 70 \%.

No Brasil atualmente há previsão normativa que permite a substituição de até $70 \%$ de clínquer por escória de alto forno (ABNT NBR 5735:1991) e de até $50 \%$ por pozolanas (ABNT NBR 5736:1991).

A preocupação em reduzir o consumo de cimento justifica-se não somente por questões ambientais, técnicas ou econômicas, mas também por questões de sustentabilidade e viabilidade do negócio do cimento. No Brasil a expectativa de grandes investimentos na década que se inicia, devido a grandes eventos esportivos e programas governamentais de infraestrutura e habitação, demandarão um aumento adicional do consumo de cimento. A abertura de novas unidades fabris exige não somente grandes investimentos em instalações e equipamentos, mas também na concessão e exploração de novas jazidas de matérias-primas, cada vez mais difíceis e onerosas devido às crescentes exigências ambientais.

Em função da grande demanda energética, um crescimento acentuado na produção de cimento pode ser limitado pelo mercado de energia, que depende do mercado internacional e de fatores ambientais. Vale lembrar que há menos de 10 anos o Brasil enfrentou grave crise energética, fazendo-se necessárias campanhas de racionamento de energia nos períodos críticos.

Outro impacto está na demanda de frete rodoviário para transportar o produto. Segundo o SNIC (2009), 94 \% da produção brasileira de cimento é transportada por rodovias. Em momentos de pico de demanda a disponibilidade de caminhões, principalmente para transporte a granel, pode se tornar crítica.

\subsection{Vantagens decorrentes do baixo consumo de cimento}

A redução do consumo de cimento não tem apenas objetivos de garantir maior longevidade para as jazidas de matérias primas do cimento ou redução dos impactos ambientais com a exploração destas jazidas e da emissão de $\mathrm{CO}_{2}$. Um uso reduzido de cimento, ou melhor, de clínquer, é também vantajoso sob alguns pontos de vista técnicos. Alguma patologia e problemática do concreto pode ter origem no alto consumo de cimento. 
As reações de hidratação do cimento Portland são exotérmicas, ocorrendo grande liberação de calor principalmente no período denominado de pega. Este período, em geral com duração de 4 a 8 horas, se caracteriza pela produção acelerada de produtos hidratados e um máximo de liberação de calor próximo ao seu fim. Uma curva típica de desenvolvimento de calor na hidratação de cimento Portland é mostrada na Figura 2.

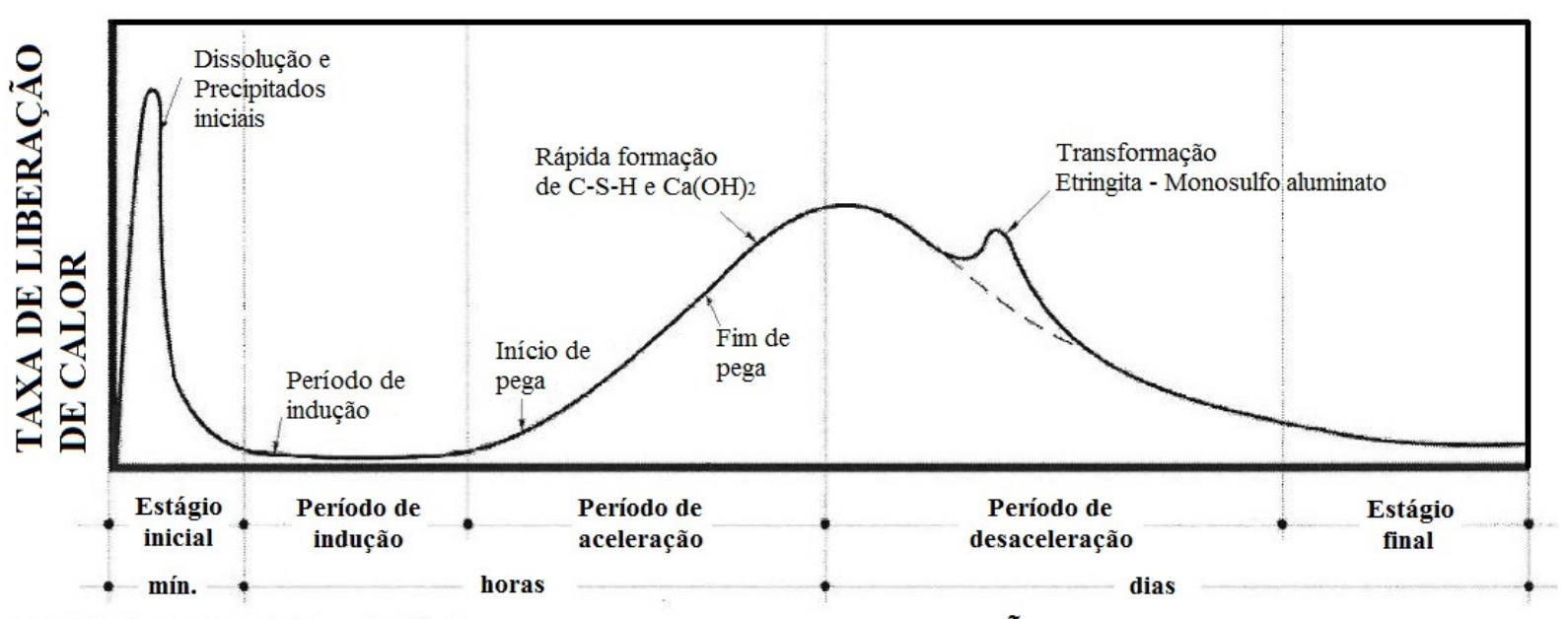

\section{TEMPO DE HIDRATAÇÃO}

Figura 2 - Representação esquemática da hidratação do cimento Portland comum, baseado na liberação de calor. Fonte: adaptada de Zampieri (1989).

A questão de liberação de calor se torna particularmente importante em estruturas massivas. Não somente em barragens, mas também em grandes blocos de fundação, paredes ou bases de equipamentos pode ocorrer elevação considerável da temperatura interna do concreto devido ao calor gerado pelas reações de hidratação. A maior parte do calor é gerada nos primeiros dias, iniciando no período de pega e se prolongando na fase posterior onde, embora as reações de hidratação desacelerem gerando menos calor, continua havendo um aumento de temperatura nos casos em que a taxa de perda de calor para o ambiente é baixa. Mehta e Monteiro (2008) citam o caso da barragem Hoover Dam, do início dos anos 30, onde se estimou que a estrutura levaria mais de 100 anos para dissipar 90 \% da elevação de temperatura gerada, por meio de processos de resfriamento naturais. É interessante ainda mencionar que um aumento da temperatura acelera as reações de hidratação $\left(\mathrm{MELO}^{7}, 2000\right)$, potencializando a geração de calor ${ }^{8}$.

\footnotetext{
${ }^{7}$ Este autor ainda concluiu que, no caso de cura térmica, a temperatura deve ser controlada, baixa e deve estar em consonância com aquela que ocorreria naturalmente com o material, numa mesma taxa de elevação, ou próximo a isso, sem o que haverá problema com o desenvolvimento da microestrutura.
} 
Com o aquecimento interno, ocorre naturalmente um aumento de volume (dilatação térmica) e, em seguida, com o esfriamento, o volume retrai novamente. Caso haja alguma restrição a esta retração, o que pode ocorrer devido a vínculos externos (ou fundações), devido às características geométricas do próprio elemento estrutural ou devido a um gradiente de temperatura entre o núcleo quente e a superfície fria, podem surgir fissuras, pois nestas idades o concreto ainda apresenta baixa resistência à tração. Estruturas projetadas com concreto de alto desempenho, muitas vezes com alto consumo de cimento, podem perder assim parte das características de alto desempenho, pois as fissuras tornamse caminhos preferenciais para a penetração de ar, água e agentes agressivos.

Um problema adicional que pode ocorrer, em casos onde se atinge temperaturas acima de $70{ }^{\circ} \mathrm{C}$, é a formação de etringita secundária. Esta pode levar à expansão e deterioração do concreto, caso haja condições favoráveis. Impedir o acesso de água e utilizar materiais cimentícios quimicamente mais resistentes, tais como escória de alto forno ou cinza volante, ajudam a prevenir danos maiores neste caso (GAJDA e ALSAMSAM, 2006).

Para concreto normal, o controle do calor de hidratação precisa ser considerado principalmente em estruturas massivas, nas quais a menor dimensão passa de $90 \mathrm{~cm}$. Porém o uso de aceleradores de pega, alto consumo de cimento ou uso de cimento de alta resistência inicial, podem exigir atenção mesmo em menores espessuras (GAJDA e ALSAMSAM, 2006).

Segundo Gajda e Alsamsam (2006), tipicamente especificam-se temperaturas máximas de $70{ }^{\circ} \mathrm{C}$ e diferença de até $20^{\circ} \mathrm{C}$ entre a temperatura máxima no interior do concreto e a temperatura ambiente. Trata-se de uma regra prática simples e em casos de interesse, especialmente quando os custos em atender a estas temperaturas se tornam consideráveis, pode-se fazer uma avaliação das propriedades térmicas e mecânicas do concreto e realizar modelagem térmica, demonstrando que as temperaturas atingidas não geram tensões que o concreto não possa suportar.

Em estruturas de grandes volumes, a escolha do tipo de cimento é de grande importância. A forma como o calor é gerado depende das características do cimento, principalmente da quantidade de substituição de clínquer por outros materiais, da finura e da constituição química.

\footnotetext{
${ }^{8}$ Interessante comentar que em caso de clima frio, um baixo calor de hidratação pode ser um problema. Por isso, em casos de temperatura ambiental abaixo de $5{ }^{\circ} \mathrm{C}$, VDZ (2008) recomenda que a temperatura do concreto esteja a pelo menos $10{ }^{\circ} \mathrm{C}$ se for utilizado consumo de cimento abaixo de $240 \mathrm{~kg} / \mathrm{m}^{3}$.
} 
VDZ (2008) mostra o acréscimo de temperatura em dois concretos com $300 \mathrm{~kg} / \mathrm{m}^{3}$ de cimento, quando é variado o tipo de cimento (Figura 3). Os cimentos, de fabricação alemã, são um cimento comum (CEM I) e um cimento de alto forno (CEM III) ${ }^{9}$. A curva contínua mostra o acréscimo de temperatura em condições adiabáticas e as curvas tracejadas em condições reais para diversas espessuras. As curvas adiabáticas mostram que há tendência de se atingir com grandes idades temperaturas próximas, independentemente do tipo de cimento. A diferença está na velocidade em que o calor é gerado.
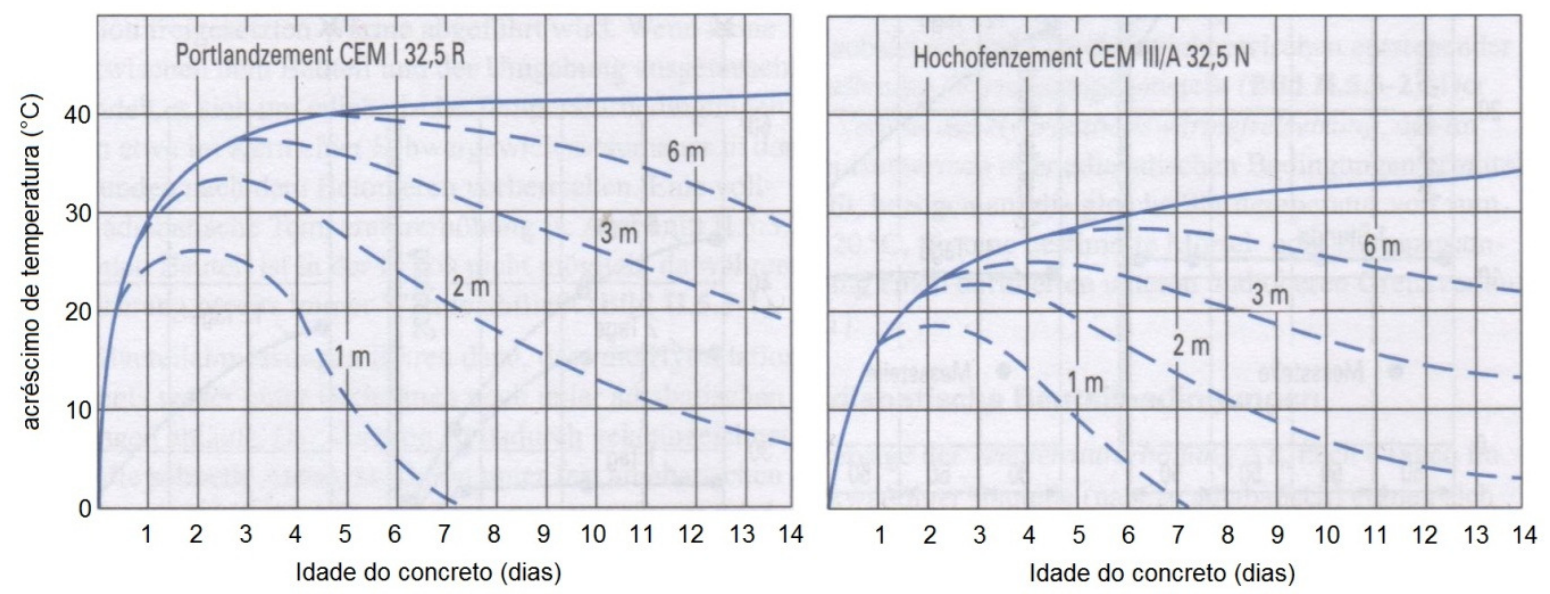

Figura 3 - Desenvolvimento de calor de hidratação em concretos de diferentes espessuras, executados com mesmo teor de cimento Portland comum (esquerda) e cimento de alto forno (direita).

Fonte: adaptada de VDZ (2008).

Em condição real, os cimentos de baixo calor de hidratação permitem que o calor gerado seja transmitido para o ambiente à medida que é gerado, evitando gradientes térmicos acentuados. No caso anterior isto é evidenciado verificando, por exemplo, que para o cimento CEM I, com dois metros de espessura ultrapassam-se os $30{ }^{\circ} \mathrm{C}$ de acréscimo de temperatura, enquanto que com CEM III, mesmo com seis metros de espessura, este limite não é alcançado. Além disso, um mesmo gradiente de temperatura é atingido em idades bem superiores, quando o concreto já apresenta maiores resistências, reduzindo os riscos de fissuração. Por exemplo, o cimento CEM I atinge acréscimo de $25{ }^{\circ} \mathrm{C}$ de temperatura com cerca de meio dia de idade, enquanto que o CEM III leva três dias para atingir o mesmo patamar.

${ }^{9}$ O cimento tipo CEM I corresponde a um cimento Portland comum, com no mínimo $95 \%$ de clínquer (correspondente ao cimento CP I brasileiro). O cimento tipo CEM III corresponde a um cimento Portland de alto forno, em geral com 36 a $80 \%$ (recentemente até $95 \%$ ) de substituição de clínquer por escória de alto forno (correspondente ao cimento CP III brasileiro). 
As principais ações tomadas para reduzir a temperatura são a escolha de cimentos de baixo calor de hidratação (mais grossos e/ou com menores teores de $\mathrm{C}_{3} \mathrm{~A}$ e $\mathrm{C}_{3} \mathrm{~S}$ ), substituição de clínquer por adições minerais (pozolanas, escórias de alto forno ou cinza volante), uso de agregados resfriados, uso de água em forma de gelo, resfriamento do concreto com nitrogênio líquido ou circulação de água fria pelo interior do volume de concreto lançado (MEHTA e MONTEIRO, 2008). O isolamento superficial com mantas isolantes pode ser empregado em alguns casos para reduzir o gradiente de temperatura (GAJDA e ALSAMSAM, 2006). Algumas destas ações podem ter um custo financeiro ou operacional relativamente alto ou depender de equipamentos ou materiais não disponíveis localmente. Assim, uma das opções mais viáveis é reduzir ao máximo o calor gerado através da redução das reações de hidratação, ou seja, reduzir ao máximo o consumo de cimento.

Gajda e Alsamsam (2006) estimam um acréscimo de $0,132{ }^{\circ} \mathrm{C}$ por $\mathrm{kg}$ de cimento Portland comum (mínimo de $95 \%$ de clínquer) por metro cúbico de concreto. Para um aumento máximo de $20^{\circ} \mathrm{C}$ isto resultaria em um consumo máximo de apenas $150 \mathrm{~kg}$ de cimento Portland comum. Convém ressaltar que esta estimativa é para elementos de grande volume com dimensão mínima a partir de 6 pés $(1,8 \mathrm{~m})$. Em estruturas como barragens, onde as resistências necessárias não são muito elevadas, baixos consumos de cimento são comuns, especialmente na forma de concreto compactado a rolo (MEHTA e MONTEIRO, 2008). Em estruturas onde se necessita de maiores resistências deve-se aliar ao baixo consumo de cimento outras ações, como, por exemplo, a redução da temperatura inicial do concreto, substituição do cimento por adições minerais ou uso de cimentos pozolânicos ou de alto forno. A Figura 4 ilustra a diferença de calor gerado para maiores consumos de cimento e também o maior tempo necessário para retornar à mesma temperatura. 


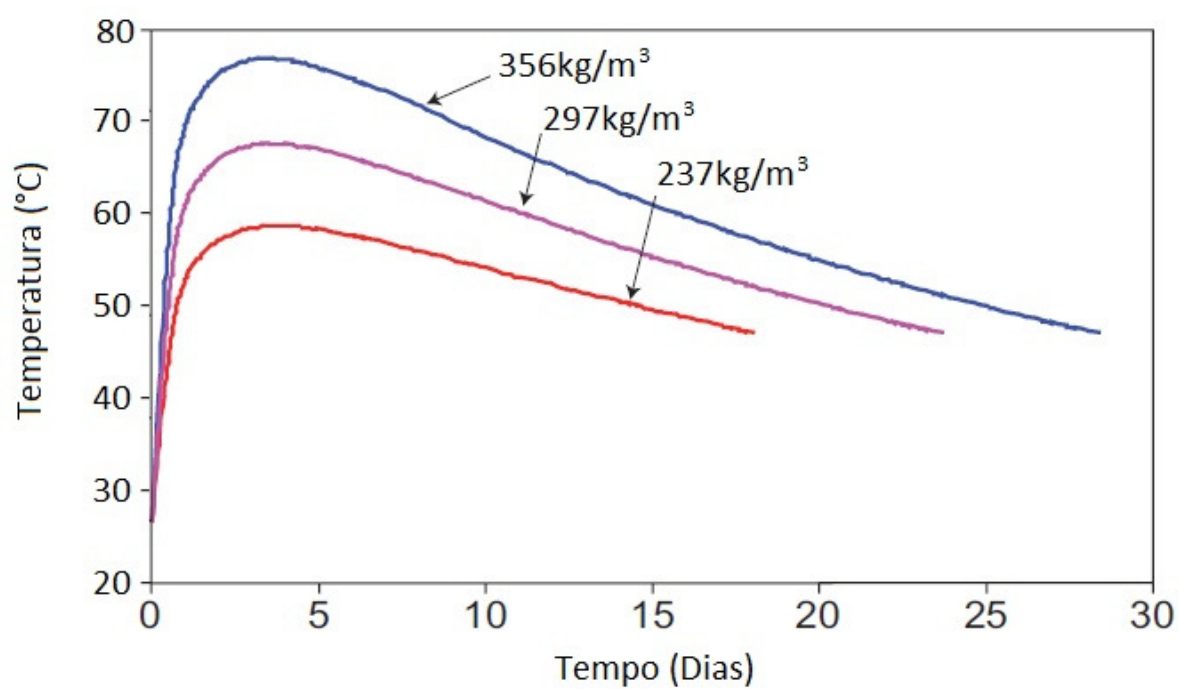

Figura 4 - Desenvolvimento de temperatura em concretos com 3,0 m de espessura e diferentes consumos de cimento Portland comum. Fonte: adaptada de Gajda e Alsamsam (2006).

O estudo da estabilidade dimensional do concreto é um assunto vasto, pela diversidade de fenômenos que ocorrem, muitas vezes sobrepondo-se uns aos outros. Um dos aspectos de mudança dimensional é a retração, que pode ser subdividida nas etapas antes e após o endurecimento. No estado fresco distingue-se retração devido ao assentamento plástico e devido à retração plástica. No estado endurecido a retração é denominada de retração por secagem.

O assentamento plástico é decorrente dos fenômenos de sedimentação e exsudação, estando relacionado à falta de finos (HASPARYK et al., 2005). Um traço de concreto comum com menor consumo de cimento terá maior tendência a estes fenômenos. Porém, um ajuste na granulometria dos agregados, adição de finos complementares e a formação de um esqueleto granular compacto de agregados, permitem reduzir a tendência de assentamento plástico, mesmo com baixo consumo de cimento.

A retração plástica compreende a contração de Le Chatelier e a retração autógena. A contração de Le Chatelier é mais frequente e intensa quanto maior for o consumo de cimento, a relação a/c e a proporção de finos no concreto (HASPARYK et al., 2005,). A retração autógena, ocorre devido à contração química e a auto dessecação. A contração química, da ordem de $8 \%$ em volume (VDZ, 2008), ocorre quando a pasta de cimento não hidratada reage formando produtos de maior densidade, sendo característica intrínseca da reação do cimento. A auto dessecação é mais intensa em concretos de alto desempenho devido ao baixo teor de água, sendo da ordem de $10^{-6} \mathrm{~m} / \mathrm{m}$ (HASPARYK et al., 2005). 
L’Hermite $^{10}$ (1960) apud Neville (1982) também mostra como a redução no consumo de cimento é benéfica do ponto de vista de redução da retração plástica (Figura 5). Estes ensaios avaliaram a retração plástica ao ar a $20{ }^{\circ} \mathrm{C}$ e $50 \%$ de umidade relativa, com vento de $1 \mathrm{~m} / \mathrm{s}$.

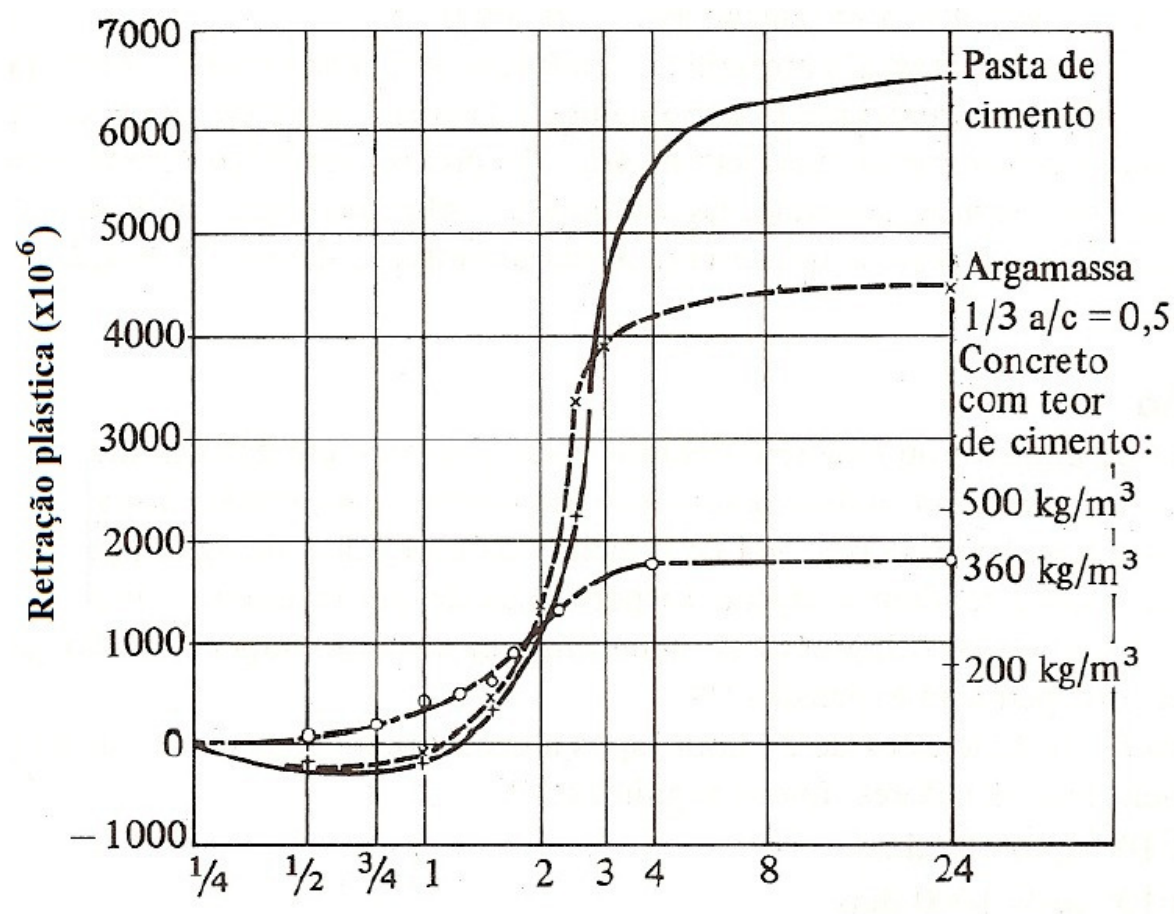

Tempo a partir do lançamento (log) - horas

Figura 5 - Evolução da retração plástica com o tempo para pasta de cimento, argamassa e concretos com diferentes teores de cimento.

Fonte: L'Hermite ${ }^{10}(1960)$ apud Neville (1982).

No estado endurecido, a retração ocorre graças à eliminação de água da estrutura capilar ou interlamelar do cimento hidratado. Com a redução da quantidade de pasta de cimento como um todo ocorre a redução da retração do concreto, pois é apenas a pasta que retrai. Complementarmente um esqueleto granular mais compacto oferece mais resistência à retração da pasta (VDZ, 2008). Grube ${ }^{11}$ (1991, apud VDZ, 2008) analisou a retração em uma pasta de cimento, curada durante $24 \mathrm{~h}$ e posteriormente mantida ao ar a $20{ }^{\circ} \mathrm{C}$ e umidade de $65 \%$, obtendo retração de aproximadamente $3 \mathrm{~mm} / \mathrm{m}$. Em um concreto equivalente com agregado quartzoso obteve apenas $0,6 \mathrm{~mm} / \mathrm{m}$. Já o uso de agregado

10 L'HERMITE, R. Volume changes of concrete. In: International Symposium on the Chemistry of Cement, $4^{\text {th }}$., 1960. Proceedings... Washington D. C., 1960, p. 659-694.

${ }^{11}$ GRUBE, H. Ursachen des Schwindens von Betton und Auswirkungen auf Betonbauteile. Düsseldorf: Beton-Verlag, 1991 (Schriftenreihe der Zementindustrie 52). 
basáltico resultou em $0,4 \mathrm{~mm} / \mathrm{m}$ e arenítico em 1,25 mm/m. A retração depende claramente do tipo de agregado, principalmente do seu módulo de elasticidade.

Um estudo de Powers ${ }^{12}$ (1961) apud Mehta e Monteiro (2008) mostra que a retração por secagem do concreto endurecido pode ser exponencialmente relacionada ao volume de fração do agregado. Quanto maior o volume de agregados, e, portanto, menor o volume de pasta de cimento, menor é a retração. A Figura 6 ilustra este efeito.

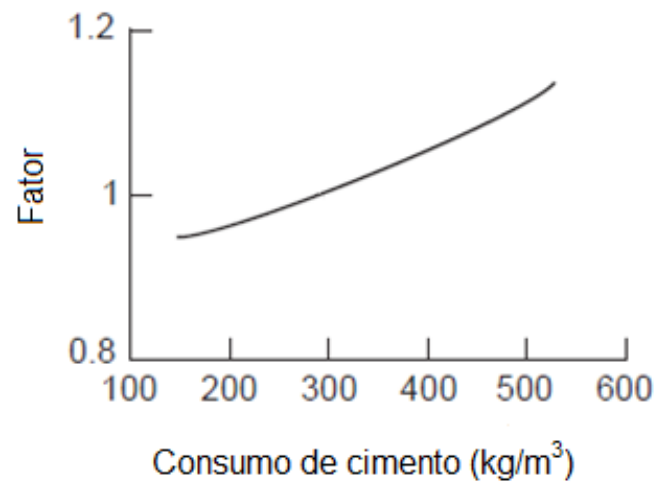

Figura 6 - Influência do consumo de cimento na retração e fluência do concreto para relação água/cimento constante.

Fonte: adaptada de Mehta e Monteiro (2008).

Resultados semelhantes são mostrados no estudo de Ödman ${ }^{13}$ (1968) apud Neville (1982). A Figura 7 mostra como para mesma relação a/c um maior consumo de agregados atua positivamente na redução da retração. Nota-se também que à medida que o teor de agregados aumenta, a relação a/c passa a ser menos influente, mostrando novamente que a rigidez do esqueleto granular atua de forma a estabilizar a retração da pasta. Convém citar que para obter preenchimento de $80 \%$ de agregados é necessário ótimo empacotamento dos agregados e baixíssimo consumo de cimento. Concretos convencionais, com consumos de cimento entre 300 e $500 \mathrm{~kg} / \mathrm{m}^{3}$ costumam ter preenchimento de agregados entre $60 \mathrm{e}$ $70 \%$.

Mehta e Monteiro (2008) citam que o uso de adições minerais e aditivos conduz a um refinamento dos poros do concreto, aumentando a quantidade de poros menores ( 3 a 20 nanometros), o que eleva a retração. Este efeito, porém, pode ser compensado pela

\footnotetext{
12 POWERS, T. C. Rev. Mater. Construct. (Paris), n. 545, pp. 79-85, 1961.

13 ÖDMAN, S. T. A. Effects of variations in volume, surface area exposed to drying, and composition of concrete on shrinkage," RILEM/CEMBUREAU, International Colloquium on the Shrinkage of Hydraulic Concretes, v. 1, 20 pp. (Madrid, 1968).
} 
melhoria no concreto, necessitando de menos água para mesma resistência, o que reduz a porosidade total e consequentemente a retração.

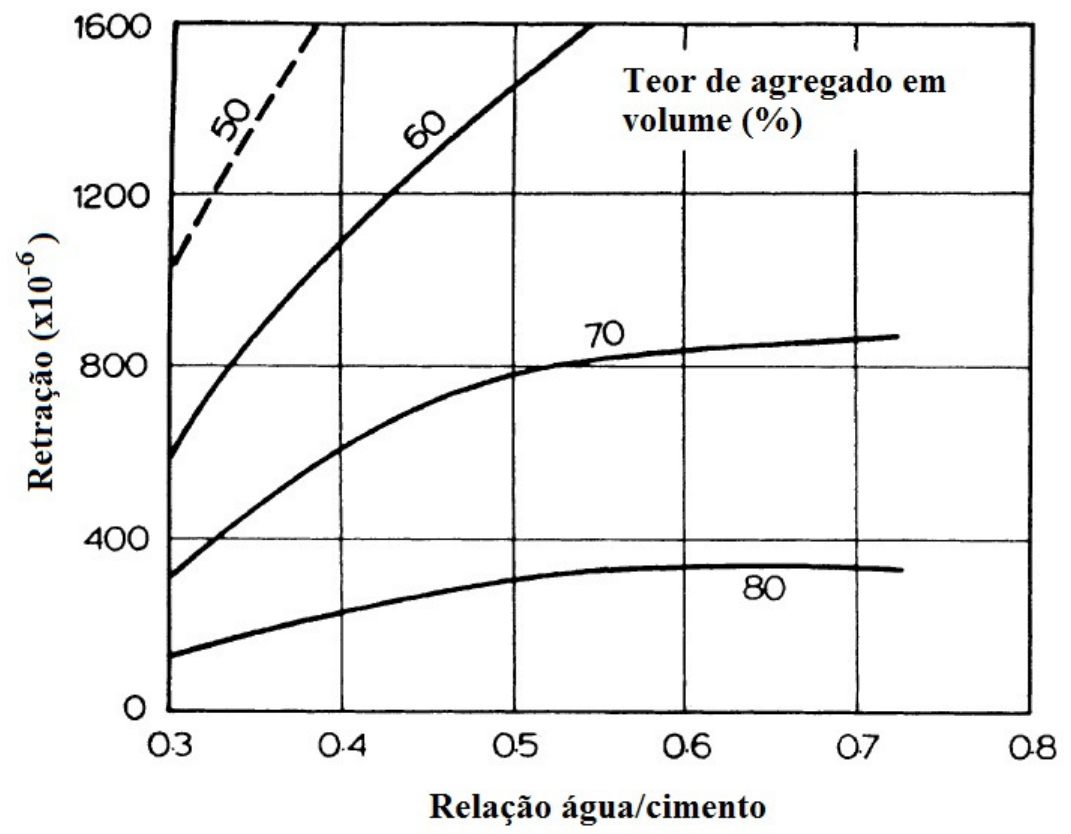

Figura 7 - Influência da relação água/cimento e do teor de agregado na retração por secagem. Fonte: adaptada de Ödman (1986) apud Neville (1982).

A presença de um esqueleto mais denso dos agregados proporciona um caminho mais longo que a água precisa percorrer para a água sair do concreto. Embora Neville (1982) afirme que normalmente a velocidade de secagem do concreto não altera a magnitude da retração final, pode haver melhorias na retração. Nas primeiras idades, quando o concreto ainda é mais poroso, a secagem mais lenta pode proporcionar menor perda de água. Também em elementos externos, onde há sazonalidade de umidade, não há tempo suficiente para ocorrer a saída de água antes da ocorrência de um novo ciclo de molhagem (chuva, por exemplo), reduzindo assim a retração.

Nota-se, portanto, que a redução do consumo de cimento é interessante do ponto de vista de retração do concreto. Isto traz vantagens especiais em alguns casos, como por exemplo, em menores perdas de proteção em estruturas protendidas e redução de patologia em pisos e reservatórios. Pisos de alto desempenho, costumeiramente executados com altos consumos de cimento, são mais propensos à retração e fissuração. Também em reservatórios de água a ocorrência de fissuração é altamente indesejada. De modo geral a ocorrência de fissuração é indesejada, tanto do ponto de vista estético e funcional, como também em termos de durabilidade, pois as fissuras são caminhos preferências para a penetração de água, ar e agentes agressivos. 
O fenômeno da fluência possui muita similaridade com o fenômeno da retração por secagem. A diferença principal está no fator que gera a expulsão de água do concreto. Enquanto que na retração a força motriz são as condições ambientais, na fluência são as tensões aplicadas. Desta forma, as reduções de retração com menores consumos de cimento, comentadas anteriormente, também podem ser aplicadas para a fluência, fato de interesse especial para estruturas protendidas que apresentarão menores perdas por fluência.

Além das vantagens técnicas citadas, é comum associar a redução do consumo de cimento com redução do custo do concreto. Esta interpretação é válida para concretos convencionais, onde são utilizados apenas materiais básicos (cimento, agregados e água). Neste caso o material que representa a maior fração do custo é sem dúvida o cimento. Embora o cimento possa ser considerado um produto de baixo custo unitário de fabricação, se comparado com outros materiais utilizados em construções, tais como aço e alumínio, o seu custo final para o usuário aumenta proporcionalmente à distância de transporte. O custo de transporte terrestre normalmente limita as vendas a uma distância de $300 \mathrm{~km}$ da fábrica. Isto é evidenciado pelo fato de que pouco cimento é comercializado e transportado internacionalmente (CSI, 2007).

Em concretos mais elaborados, a incorporação de outros materiais tais como adições minerais, aditivos químicos, fílers e fibras, alteram o perfil de composição de custo do concreto, pois o custo destes materiais passa a ter peso considerável. Uma redução do consumo de cimento, acompanhada pelo aumento do consumo de outros materiais, deve ser avaliada para cada caso particular, já que os custos são muito dependentes de tipos e marcas e também de localização, devido a diferenças nos custos de frete e impostos locais.

No entanto, é possível obter custos menores reduzindo o consumo de cimento mesmo adicionando outros materiais. Um exemplo pode ser encontrado no trabalho apresentado por Rebmann, Trigo e Liborio (2010), onde se comparou dois concretos produzidos com cimento CP II-Z-32, sendo um convencional e outro com propriedades aprimoradas por meio de aplicação de técnicas de dispersão e empacotamento de partículas. O concreto convencional apresentou índice de consumo de cimento de 10,7 $\mathrm{kg} / \mathrm{m}^{3}$ por MPa de resistência à compressão e o concreto aprimorado de $6,3 \mathrm{~kg} \cdot \mathrm{m}^{-3} \cdot \mathrm{MPa}^{-1}$, obtendo-se assim redução de consumo de cimento de $41 \%$. Vale ressaltar que este desempenho foi obtido mais em função da melhora da resistência à compressão, que passou de 24,3 MPa para 41,1 MPa aos 28 dias, que na efetiva redução do consumo de cimento. 
$\mathrm{Na}$ Tabela 1 indicam-se os consumos dos materiais destes dois concretos e indicamse também os custos unitários dos materiais, conforme praticados na região de São Carlos / SP em 2010. Com base nestes dados pode-se calcular o índice de custo de 7,72 R $\$ \cdot \mathrm{m}^{-3} \cdot \mathrm{MPa}^{-1}$ para o concreto convencional e 5,65 $\mathrm{R} \$ \cdot \mathrm{m}^{-3} \cdot \mathrm{MPa}^{-1}$ para o traço aprimorado. Este exemplo simples mostra que é possível obter um melhor desempenho de custo, mesmo com a incorporação de materiais a princípio mais caros que o próprio cimento. Cabe salientar ainda que foi considerado apenas o custo dos materiais. A análise de viabilidade técnica-financeira completa deve ser realizada sempre no local de aplicação, com os materiais disponíveis, os custos dos materiais postos na obra e também de todos os custos que envolvem a produção e aplicação do concreto, tais como equipamentos e mão de obra.

Tabela 1 - Consumo de materiais, em kg, e custos de dois concretos, um convencional e outro aprimorado.

\begin{tabular}{cccccccccc}
\hline Traço / & \multirow{2}{*}{ Cimento } & Sílica & \multicolumn{4}{c}{ Agregados } & Adit. & \multirow{2}{*}{ Água } \\
\cline { 4 - 9 } & & Ativa & Brita 1 & Pedrisco & Areia & Fíler & SP & \\
\hline Convencional & 260 & - & 1183 & - & 832 & - & - & 160 \\
\hline Aprimorado & 235 & 18 & 675 & 448 & 636 & 274 & 3,1 & 159 \\
\hline Custos $(\mathrm{R} \$ / \mathrm{kg})$ & 0,38 & 1,20 & 0,04 & 0,04 & 0,05 & 0,05 & 10,00 & 0,00 \\
\hline
\end{tabular}

Fonte: adaptada de Rebmann, Trigo e Liborio (2010).

\subsection{Indicadores de baixo consumo de cimento}

O consumo de cimento é tradicionalmente expresso em termos de massa de cimento empregada por volume de concreto produzido. No Brasil e demais países que adotam o Sistema Internacional de Unidades ${ }^{14}$ o consumo é costumeiramente expresso em $\mathrm{kg} / \mathrm{m}^{3}$. Consumos tradicionais estão situados entre 250 e $750 \mathrm{~kg} / \mathrm{m}^{3}$. Esta forma de expressar o consumo, porém, não tem relação com as características do concreto resultante. Maior consumo de cimento nem sempre está relacionado a maior resistência. Tiboni (2007), por exemplo, relata traços de concreto produzidos com os mesmos materiais em que obteve em um traço 1:6,5 resistências à compressão superiores ao traço 1:3,5. Neste caso a diferença estava no grau de dispersão das partículas devido ao uso diferenciado de superplastificante.

Um melhor indicativo de consumo seria então aquele que relaciona a quantidade necessária de cimento para produzir certa quantidade de um parâmetro escolhido,

\footnotetext{
${ }^{14}$ No sistema inglês (imperial) é comum ser expresso em lb/yd ${ }^{3}$ (libras por jarda cúbica). $1 \mathrm{lb} / \mathrm{yd}{ }^{3}$ equivale a aproximadamente $0,593 \mathrm{~kg} / \mathrm{m}^{3}$.
} 
permitindo assim avaliar o desempenho obtido pela quantidade de cimento empregada. Matematicamente este consumo relativo pode ser expresso pela equação:

$$
C_{r}=\frac{C}{p}
$$

sendo $C$ o consumo de cimento e $p$ o parâmetro escolhido.

O principal parâmetro de referência dos concretos, e o mais controlado, é a resistência à compressão, sendo a idade de 28 dias aceita como padrão na maioria dos casos. Assim, um índice de consumo que leva em consideração a resistência à compressão é a quantidade de cimento em um $\mathrm{m}^{3}$ de concreto necessário para produzir $1 \mathrm{MPa}$ de resistência à compressão. Por exemplo, um concreto convencional, com consumo de cimento de $350 \mathrm{~kg} / \mathrm{m}^{3}$, que alcança resistência à compressão de $35 \mathrm{MPa}$ aos 28 dias, terá, portanto, um $\mathrm{C}_{\mathrm{r}}$ igual a $10 \mathrm{~kg} \cdot \mathrm{m}^{-3} \cdot \mathrm{MPa}^{-1}$. Em alguns casos a resistência à compressão não é o quesito principal na avaliação de desempenho de um concreto. No caso de pisos, por exemplo, a resistência de maior interesse é a resistência à tração na flexão. Índices de consumos em relação a este parâmetro serão neste caso mais apropriados. Outros índices podem ser propostos, conforme o parâmetro de desempenho mais apropriado para cada caso.

Uma variação deste índice é considerar, além do consumo de cimento, também os demais materiais aglomerantes porventura presentes, tais como sílica ativa, metacaulinita, escória de alto-forno, cinza volante.

Com vistas à questão ambiental há interesse em avaliar a quantidade de $\mathrm{CO}_{2}$ emitida e a energia consumida no processo de produção do concreto. Estes dois quesitos estão relacionados principalmente à produção do clínquer. Também algumas características do concreto, como o calor de hidratação, por exemplo, estão ligadas principalmente à quantidade de clínquer disponível. Pode-se assim propor ainda um índice de kg de clínquer por MPa produzido em um metro cúbico de concreto.

Mais relacionado ainda à sustentabilidade ambiental pode-se ainda calcular a quantidade de $\mathrm{CO}_{2}$ emitido por MPa produzido. A vantagem deste índice é a possibilidade de permitir a inclusão das emissões decorrentes dos demais materiais componentes do concreto e do processo de produção e entrega.

Damineli et al. (2010) realizaram um levantamento de grande quantidade de publicações nacionais e internacionais para avaliar em que níveis de consumo se encontram os concretos atualmente produzidos. Analisaram-se dois parâmetros: Binder intensity (bi) e $\mathrm{CO}_{2}$ intensity (ci), onde Binder intensity é o consumo relativo de todos os materiais 
aglomerantes em relação à resistência à compressão aos 28 dias e $\mathrm{CO}_{2}$ intensity é a relação entre o total de $\mathrm{CO}_{2}$ emitido na produção e transporte dos materiais que compõe o concreto em relação à resistência à compressão aos 28 dias. Por simplificação, devido à falta de informações detalhadas nas publicações pesquisadas, para a estimativa da emissão de $\mathrm{CO}_{2}$ considerou-se apenas a quantidade relativa à produção da fração de clínquer presente nos traços. Esta é a parcela majoritária na emissão de $\mathrm{CO}_{2}$. Também, por carência de informações detalhadas sobre a produção de cada cimento utilizado nas diversas publicações pesquisadas, assumiu-se neste levantamento emissão de 1 (uma) tonelada de $\mathrm{CO}_{2}$ por tonelada de clínquer. A quantidade de clínquer no cimento foi estimada com base em médias dos limites estabelecidos pelas normas que controlam a fabricação de cimento. Portanto, este índice acaba refletindo apenas o consumo de clínquer, negligenciando as outras contribuições e a eficiência da produção do fabricante de cimento, que pode ter emissões de $\mathrm{CO}_{2}$ inferiores aos adotados, conforme a eficiência energética e combustível utilizado.

$O$ resultado do levantamento mostrou valores de binder intensity variando de 4,3 kg. $\mathrm{m}^{-3} \cdot \mathrm{MPa}^{-1}$ até $29 \mathrm{~kg} \cdot \mathrm{m}^{-3} \cdot \mathrm{MPa}^{-1}$, sendo que a maior parte dos concretos encontra-se entre 5 e $15 \mathrm{~kg} \cdot \mathrm{m}^{-3} \cdot \mathrm{MPa}^{-1}$. O concreto com menor valor encontrado foi desenvolvido por Catoia et al. (2008a) no Laboratório de Materiais Avançados a Base de Cimento (LMABC) da Escola de Engenharia de São Carlos e baseou-se em um cimento de alta reatividade (Duracem AD300 da Holcim Brasil), empacotamento dos agregados, adição de sílica ativa e uso de superplastificante comercial.

Vale destacar alguns trabalhos desenvolvidos no LMABC nos últimos quatro anos. Tiboni (2007) produziu um concreto com abatimento de $120 \mathrm{~mm}$, resistência à compressão aos 28 dias de $58 \mathrm{MPa}$, consumo de cimento Portland de $269 \mathrm{~kg} / \mathrm{m}^{3}$ e $47,5 \mathrm{~kg} / \mathrm{m}^{3}$ de cinza da casca do arroz. O consumo relativo de aglomerantes deste concreto equivale a $5,5 \mathrm{~kg} \cdot \mathrm{m}^{-3} \cdot \mathrm{MPa}^{-1}$. Catoia et al. (2008b) desenvolveram um concreto autoadensável, obtendo resistência à compressão aos 28 dias de 59,9 MPa com consumo de cimento de $289 \mathrm{~kg} / \mathrm{m}^{3}$ e de aglomerantes de $317 \mathrm{~kg} / \mathrm{m}^{3}$, atingindo assim um consumo relativo de aglomerantes de $5,4 \mathrm{~kg} \cdot \mathrm{m}^{-3} \cdot \mathrm{MPa}^{-1}$. Pereira (2010) também desenvolveu um concreto autoadensável, inclusive com adição de fibras de lã de rocha e poliamida. Em concretos com consumo de aglomerantes em torno de $360 \mathrm{~kg} / \mathrm{m}^{3}$ obteve resistências aos 28 dias de até $71 \mathrm{MPa}$, atingindo um consumo relativo de aglomerantes de 5,0 $\mathrm{kg} \cdot \mathrm{m}^{-3} \cdot \mathrm{MPa}^{-1}$. Catoia, Conceição e Liborio (2009) reduziram o consumo total de cimento abaixo dos limites normativos convencionais, obtendo um concreto de $37,6 \mathrm{MPa}$ com consumo de 
aglomerantes de $209 \mathrm{~kg}$, o que equivale a um consumo relativo de aglomerantes de $5,6 \mathrm{~kg} \cdot \mathrm{m}^{-3} \cdot \mathrm{MPa}^{-1}$.

Damineli et al. (2010) preveem que consumos de aglomerantes abaixo de $5 \mathrm{~kg} \cdot \mathrm{m}^{-3} \cdot \mathrm{MPa}^{-1}$ sejam possíveis para concretos abaixo de $50 \mathrm{MPa}$ em um futuro não muito distante. Sugerem, porém, que avaliações sistemáticas de durabilidade e comportamento na ruptura sejam realizadas, pois a resistência à compressão pode não ser o único parâmetro a definir o consumo mínimo de cimento.

Wassermann, Katz e Bentur (2009) avaliaram concretos com consumos de cimento entre 230 a $450 \mathrm{~kg} / \mathrm{m}^{3}$ e relações água/cimento variando entre 0,45 a 0,70. Os consumos relativos variaram entre 5,7 e $7,9 \mathrm{~kg} \cdot \mathrm{m}^{-3} \cdot \mathrm{MPa}^{-1}$. Concluíram que a resistência à compressão e a profundidade de carbonatação são dependentes diretamente da relação água/cimento, porém independentes do consumo de cimento. A absorção total, absorção por capilaridade e penetração de cloretos dependem do consumo de cimento, sendo menores para os concretos com menor consumo de cimento. Esta melhora é justificada pelo refinamento da estrutura de poros obtida graças ao uso de superplastificantes, que permitem melhor dispersão das partículas. No caso da carbonatação, dois fatores contrários influenciam o resultado, por um lado a redução da porosidade e por outro lado a reserva alcalina reduzida. Com base nestes resultados concluem que a redução no consumo de cimento não é acompanhada por nenhum efeito negativo da durabilidade, pelo contrário, há até melhorias em alguns aspectos. Sugerem por fim que as recomendações de consumos mínimos de cimento pelas normas devem ser revistas.

$\mathrm{Na}$ direção de concretos com Ultra Alta Resistência, ou Ultra-High Performance Concrete (UHPC), encontram-se dados do concreto comercial Ductal® (VERNET ${ }^{15}, 2004$, apud DAMINELI et al., 2010) com $1195 \mathrm{~kg}$ de aglomerante e $230 \mathrm{MPa}$ de resistência, atingindo consumo relativo de aglomerantes de $5,2 \mathrm{~kg} \cdot \mathrm{m}^{-3} \cdot \mathrm{MPa}^{-1}$. Em uma experiência de aplicação de UHPC, na ponte Gärtnerplatzbrücke em Kassel/Alemanha, foi desenvolvido um concreto com $1000 \mathrm{~kg} / \mathrm{m}^{3}$ de aglomerantes, obtendo-se resistência à compressão de $179 \mathrm{MPa}$, ou seja, consumo de aglomerantes de $5,6 \mathrm{~kg} \cdot \mathrm{m}^{-3} \cdot \mathrm{MPa}^{-1}$ (GOLDBACH e STEHLING, 2008; KRELAUS, SCHMIDT e FREISINGER, 2008).

\footnotetext{
${ }^{15}$ VERNET, C. P. Ultra-durable concretes: structure at the micro and nanoscale. Materials Research Society Bulletin, v. 29, n. 5, p. 324-327, maio 2004.
} 


\subsection{Consumo mínimo de cimento}

Segundo a ABNT NBR 12.655:2006, dependendo da classe de agressividade em que se encontra a estrutura de concreto, o consumo mínimo varia de 260 a $360 \mathrm{~kg} / \mathrm{m}^{3}$. Paralelamente há ainda restrição de máximo fator água/cimento e mínima resistência. Não há variação nestes valores em função do tipo de cimento ou do uso de adições minerais ou aditivos.

A norma europeia CEN EN 206-1 dá apenas algumas informações básicas, deixando a cargo dos países membros o estabelecimento de limites.

Na Grã-Bretanha a BSI BS 8500:2006 especifica o consumo mínimo de cimento para concretos estruturais de acordo com a exposição, agressividade ambiental, tipo de cimento, tipo de elemento e cobrimento da armadura, variando desde $240 \mathrm{~kg}$ para ambientes internos até $380 \mathrm{~kg}$ para diversos casos como, por exemplo, elementos que podem ter contato com sais de degelo e ambiente litorâneo. Permite ainda reduções em casos de cobrimentos crescentes. Estruturas verticais protegidas de chuva, por exemplo, podem ter os consumos reduzidos de $340 \mathrm{~kg}$ para $300 \mathrm{~kg}$ ao se passar de cobrimento 20 para $25 \mathrm{~mm}$. Reduções adicionais para $280 \mathrm{~kg}$ e $260 \mathrm{~kg}$ podem ser admitidas aumentando os cobrimentos para $30 \mathrm{e}$ $35 \mathrm{~mm}$, respectivamente.

$\mathrm{Na}$ Alemanha a especificação é dada pela EN 206-1/DIN 1045-2, segundo a qual elementos internos devem ter consumo mínimo de $240 \mathrm{~kg}$ e externos de $280 \mathrm{~kg}$, podendo ser reduzido para $270 \mathrm{~kg}$ com uso de adições minerais (VDZ, 2008). Os valores também variam conforme classes de agressividade ambiental, porém independem do tipo de cimento (VDZ, 2008).

Wassermann, Katz e Bentur (2009) citam três motivos que possivelmente sejam a origem destas especificações mínimas por boa parte das normas:

- Resquícios da época em que a única forma de controlar o fator água/cimento, para mesma trabalhabilidade, era por meio do consumo de cimento. Hoje com o emprego de aditivos plastificantes e superplastificantes há a possibilidade de redução do $\mathrm{a} / \mathrm{c}$ mesmo sem aumento do consumo de cimento.

- Possibilitar um mínimo de finos para permitir adequada trabalhabilidade e garantir e ligação concreto-aço. Um maior teor de finos também aumenta a coesão da mistura, evitando a segregação e exsudação. Existem, no entanto, outras possibilidades para aumentar a proporção de finos sem aumentar o consumo de cimento. Areias muito 
finas, pós de sílica, calcário, diversas adições minerais e rejeitos em forma de pó de diversas origens podem ser empregadas.

- Aumentar a proteção do aço ao permitir fixação de cloretos e $\mathrm{CO}_{2}$ que penetram no concreto pela estrutura capilar. Este motivo, caso seja verdadeiro, exigiria consumos mínimos de cimento mesmo em concretos modernos. Como a penetração destes agentes agressivos depende também da porosidade do concreto, um estudo considerando ambos os fatores se torna necessário para fixação de consumos mínimos.

Baseado em ensaios realizados, já citados na seção anterior, estes autores recomendam que as especificações de consumos mínimos de cimento sejam revistos.

Convém citar ainda um caso especial de concreto que é aquele compactado com rolos compactadores, utilizado basicamente em barragens e sub-bases e bases de rodovias. A norma DNIT 056/2004-ES, destinada a sub-bases de concreto rolado para pavimento rígido, fixa o consumo de cimento entre 80 e $120 \mathrm{~kg} / \mathrm{m}^{3}$. As resistências, porém, são muito inferiores aos concretos estruturais, devendo atingir apenas 5,0 MPa aos 7 dias. Para pavimentos rígidos a DNIT 059/2004-ES especifica um consumo mínimo de $200 \mathrm{~kg} / \mathrm{m}^{3}$. Já em barragens são comuns consumos de $70 \mathrm{~kg} / \mathrm{m}^{3}$, obtendo-se resistências em idades avançadas menores que $9 \mathrm{MPa}$ (KUPERMAN, 2005).

O uso intensivo de pozolanas também é comum. Com estas há crescimento de resistências a longos prazos. Mehta e Monteiro (2008) relatam concretos com $77 \mathrm{~kg}$ de cimento e $140 \mathrm{~kg}$ de pozolana, atingindo 34,2 MPa com um ano de idade. A USACE (US Army Corps of Engineers) cita em seu manual de engenharia EM 1110-2-2006 (2000) resistências de $13,8 \mathrm{MPa}$ a $20,7 \mathrm{MPa}$ em idades entre 90 dias a 1 ano. Por razões de durabilidade apenas, uma resistência mínima de 13,8 MPa é recomendada.

\subsection{Produção de concreto de alta resistência com baixo consumo de cimento}

Considerando que há indicações de viabilidade técnica e econômica para o uso de concretos com baixo consumo de cimento, esta seção se dedica a analisar caminhos que permitem a elaboração de bons concretos com baixo consumo de cimento. Antes, porém, vale lembrar que as boas técnicas de execução do concreto permanecem válidas e não podem ser negligenciadas. Cuidados na execução de formas e armação, atenção no lançamento, adensamento e cura, planejamento da desenforma e retirada de escoramentos, 
bem como um controle tecnológico dos materiais e do concreto produzido, continuam sendo princípios básicos e de grande importância para obtenção de concretos com boa aparência, resistência e durabilidade.

A resistência de um material está intrinsecamente relacionada à sua porosidade. Powers $^{16}$ (1958) apud Mehta e Monteiro (2008) observou que em argamassas pode-se estabelecer a seguinte relação entre a resistência à compressão $f_{c}$ e a fração de volume ocupada por material sólido $x$ :

$$
f_{c}=a \cdot x^{3}
$$

No caso de porosidade nula $(x=1)$ atinge-se a resistência máxima $(a)$, intrínseca do material.

Para maximizar a resistência do material deve-se, portanto, buscar reduzir a quantidade de vazios o máximo possível. A porosidade de uma pasta de cimento é resultante da água utilizada na mistura que não é consumida pelas reações de hidratação. Quanto maior a quantidade de água em relação ao cimento, maiores serão os espaços ocupados inicialmente por água e que posteriormente são preenchidos por ar, água livre e grandes cristais de $\mathrm{Ca}(\mathrm{OH})_{2}$. A estreita relação entre o fator água/cimento e a resistência à compressão foi observada em concretos já em 1918 por Duff Abrams e se tornou um dos principais pilares na tecnologia do concreto, sendo mundialmente aceito (HELENE, 2005). Matematicamente esta relação é expressa por:

$$
f_{c}=\frac{k_{1}}{k_{2}{ }^{a / c}}
$$

sendo $f_{c}$ a resistência à compressão, a/c a relação água/cimento e $k_{1}$ e $k_{2}$ duas constantes a serem determinadas experimentalmente.

Convém salientar que no concreto a porosidade da pasta de cimento não é a razão única que determina a resistência. As propriedades da zona de transição entre o agregado graúdo e a matriz têm grande influência na resistência, pois é uma região mais porosa, com concentração maior de produtos mais frágeis e onde haverá a formação preferencial de microfissuras. A razão pela qual a lei de Abrams continue sendo válida mesmo assim devese ao fato de que a redução de água propicia não somente menor porosidade da matriz, mas também a melhora na zona de transição. Esta, ao se tornar menos porosa, impede a formação de grandes cristais frágeis e reduz a microfissuração.

\footnotetext{
${ }^{16}$ POWERS, T. C. J. American Ceramic Society, v. 41, n.1, pp. 1-6, 1958.
} 
Segundo Scrivener, Crumbie e Laugesen (2004) a origem da zona de transição está no efeito "parede" proporcionado pela superfície do agregado, que interrompe o empacotamento dos grãos de cimento próximos a ela. Como pode ser visto na Figura 8, se um objeto de maiores dimensões (um agregado graúdo, elemento de fôrma ou armadura) for colocado em um conjunto aleatório de grãos, ele cortará completamente muitos grãos (A). Como isto é fisicamente impossível, o empacotamento normal dos grãos é interrompido, criando uma zona com porosidade mais elevada e com grãos menores próximos à parede (B).
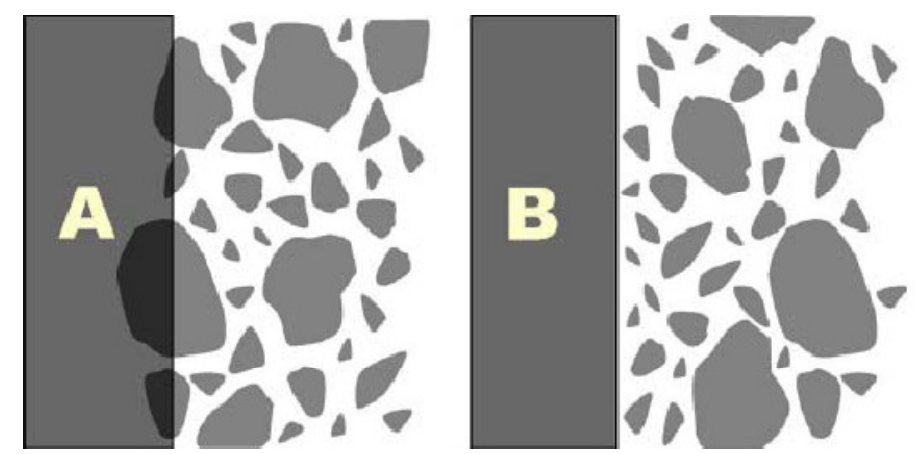

Figura 8 - Ilustração do efeito Parede.

Fonte: Scrivener, Crumbie e Laugesen (2004).

O efeito "parede" é diretamente responsável pelas características na zona de transição, principalmente pela sua maior porosidade. Uma explicação complementar para as características especiais dessa região é que durante a vibração do concreto, o efeito de exsudação interna conduz ao acúmulo de água sob as partículas de agregado, acarretando em heterogeneidade nos gradientes de água e cimento anidro em torno das partículas (SCRIVENER, CRUMBIE e LAUGESEN, 2004; AÏTCIN, 2000; SILVA, 2000). Este efeito também é importante para a durabilidade do concreto. As fôrmas utilizadas na produção dos elementos estruturais atuam como "paredes" e conduzem à formação de camada superficial mais rica em pasta e com maior relação a/c. A espessura de cobrimento das armaduras, a principal responsável pela proteção destas, fica assim com uma qualidade reduzida. Isto ocorre principalmente com concretos de alto abatimento, obtidos por meio do uso de superplastificantes (LIBORIO, 1990; AïTCIN, 2000).

Durante a hidratação do cimento anidro são formadas duas fases hidratadas principais - o silicato de cálcio hidratado, C-S-H, e o hidróxido de cálcio, $\mathrm{Ca}(\mathrm{OH})_{2}$ ou $\mathrm{CH}$. Nos primeiros segundos, a concentração de silicato na solução permanece muito baixa e consequentemente a fase C-S-H é, na maior parte, depositada diretamente em volta dos grãos de cimento. Diferentemente, a concentração de cálcio na solução é muito alta e o $\mathrm{CH}$ 
é depositado, na maior parte, dentro dos poros (SCRIVENER, CRUMBIE e LAUGESEN, 2004; MELO, 2000; SILVA, 2000).

Como a zona de transição é inicialmente mais porosa isto favorece o depósito de maior quantidade de $\mathrm{CH}$ nesta região. $\mathrm{O} \mathrm{CH}$ é um composto mais frágil que o $\mathrm{C}-\mathrm{S}-\mathrm{H}$ e, além disso, o fato do $\mathrm{CH}$ ser orientado preferencialmente com o eixo central normal à superfície do agregado favorece o surgimento de microfissuras nessa região.

Desta forma, pode-se dizer que a zona de transição, região com espessura de 10 a $50 \mu \mathrm{m}$, é, geralmente, mais fraca que as outras duas fases do concreto, exercendo influência muito maior sobre o comportamento mecânico (por ser um local suscetível à formação de microfissuras) e sobre a durabilidade deste material (MASO, 1996).

Em geral, para obter um concreto convencional sem uso de aditivos plastificantes, com dada trabalhabilidade e mesmo conjunto de materiais, é necessária uma quantidade de água por $\mathrm{m}^{3}$ de concreto que não difere muito entre traços de diferentes resistências. $A$ maior ou menor resistência é obtida pela variação na quantidade de cimento. Para obter maior resistência, por exemplo, aumenta-se o consumo de cimento, obtendo-se desta forma menores relações a/c, e consequentemente maiores resistências. Passou-se, assim, a relacionar no meio prático a maior resistência com maior consumo de cimento. No entanto há possibilidades de alterar a relação a/c sem consumir mais cimento. Por exemplo, o uso de aditivos plastificantes reduz a quantidade de água necessária para a mesma trabalhabilidade. Tendo isto em mente Wassermann, Katz e Bentur (2009) mostraram que a resistência à compressão depende sim diretamente da relação água-cimento, como previsto pela Lei de Abrams, mas não do consumo de cimento.

A busca por ganhos de resistência e redução de consumo de cimento, passa então a ser definida pelo ajuste de uma série de fatores que podem influenciar a resistência de um concreto. Aborda-se aqui: (1) Redução do fator água/cimento; (2) Melhoria da zona de interface e refinamento da estrutura de poros; (3) Escolha adequada dos agregados; (4) Máximo preenchimento do volume do concreto pelos agregados; (5) Procedimento e eficiência da mistura; e (6) Tipos de cimentos. Convém lembrar mais uma vez que aspectos da produção da estrutura interferem no desempenho final. Portanto, boas técnicas de execução, com atenção principalmente para o lançamento, adensamento, cura, desenforma e retirada de escoramentos, devem ser empregadas para manter a qualidade do concreto produzido. 


\subsubsection{Redução do fator água/cimento}

Quando se pretende reduzir o fator água/cimento sem incorrer em aumentos do consumo de cimento, necessariamente deve-se reduzir a parcela de água. O modo mais simples e eficiente de se obter isto é pelo uso de aditivos plastificantes ou superplastificantes, redutores de água. Quando se busca um máximo de redução de cimento deve-se buscar trabalhar com o mínimo de água possível. Isto somente pode ser atingido caso o aditivo utilizado for de alta eficiência, dando-se preferência aos superplastificantes.

A ABNT NBR 11768:1992 define aditivo plastificante como "Produto que aumenta o índice de consistência do concreto mantida a quantidade de água de amassamento, ou que possibilita a redução de, no mínimo, $6 \%$ da quantidade de água de amassamento para produzir um concreto com determinada consistência." Já como superplastificante define "Produto que aumenta o índice de consistência do concreto mantida a quantidade de água de amassamento, ou que possibilita a redução de, no mínimo, 12 \% da quantidade de água de amassamento, para produzir um concreto com determinada consistência." Alguns produtos aliam a estas características de plastificação outras, como retardamento ou aceleração de pega e resistência.

Em uma pasta de cimento as partículas anidras de cimento tendem a se atrair e formar flocos, os quais aprisionam grandes quantidades de água da mistura e ar ou até mesmo comportando-se como uma grande partícula de cimento. Em um sistema de pasta de cimento altamente floculada, não apenas o tamanho e a forma dos poros, mas também os produtos cristalinos da hidratação são diferentes quando comparados a um sistema bem disperso (MEHTA e MONTEIRO, 2008).

A dispersão das partículas pequenas (cimento e adições minerais) é necessária para obter um concreto com trabalhabilidade melhorada. Devido à elevada tensão superficial da água, a tendência natural dos grãos de cimento e adições, quando entram em contato com a água, é agruparem-se na forma de flocos, aprisionando parte da água de amassamento, tornando-a indisponível para fluidificação da mistura. Com o uso de aditivos químicos, que reduzem a tensão superficial da água, é possível dispersar estas partículas finas, disponibilizando mais água. Efeitos eletrostáticos, estéricos ou eletroestéricos geram forças repulsivas na superfície das partículas, afastando-as umas das outras, permitindo maior mobilidade das partículas e consequentemente fluidez do sistema.

A interação cimento-aditivo depende das propriedades físicas e químicas de ambos. Altas reduções de água e boa manutenção de trabalhabilidade ao longo do tempo são 
obtidas quando ocorre compatibilidade entre aditivo e cimento. FORMAGINI (2005, p.119) considera que:

[...] a escolha de um bom e eficiente dispersante é tão importante quanto a do cimento. Nem todos os tipos e marcas disponíveis comercialmente possuem a mesma eficiência na dispersão das partículas de cimento, na redução da quantidade de água de mistura e no controle da reologia de um traço com relação água/materiais cimentícios muito baixa, principalmente durante a primeira hora após o contato do cimento com a água. Estudos detalhados sobre a interação entre diferentes tipos de cimentos e dispersantes foram conduzidos por Chandra e Björnström, demonstrando que a seleção do tipo de dispersante a ser utilizado na produção de concretos pode alterar significativamente o processo de hidratação e a microestrutura da pasta hidratada. Logo, sua escolha deverá ser criteriosa.

Devido à diversidade de aditivos e cimentos, a interação entre o cimento e o aditivo pode levar a resultados diversos. O grau de fluidificação, a manutenção da trabalhabilidade, segregação, retardamento e incorporação de ar são alguns dos itens que devem ser observadas (AITCIN, JOLICOEUR e MacGREGOR ${ }^{17}$, 1994, apud CASTRO, 2007). Quando ocorre algum prejuízo nestas propriedades diz-se que houve incompatibilidade entre o cimento e o aditivo. Por questões de praticidade em geral realiza-se o estudo desta compatibilidade em pastas de cimento e não em concretos. Jiang, Kim e Aïtcin ${ }^{18}$ (2000) apud Castro (2007) comentam que informações a respeito de abatimento e a manutenção deste podem ser transferidas da pasta para o concreto. Neste sentido são normalmente utilizados dois ensaios: miniabatimento e cone de Marsh.

O ensaio de miniabatimento, proposto inicialmente por Kantro ${ }^{19}$ (1980) apud Bucher ${ }^{20}$ (1998) apud Castro (2007), consiste no preparo de uma pasta de cimento e preenchimento de uma fôrma no formato de um minitronco de cone. Após o preenchimento, a fôrma é levantada e a pasta se espalha sobre uma superfície plana. A área de espalhamento é o parâmetro de medição o qual é relacionado à trabalhabilidade da pasta. Quanto maior a área, maior é a trabalhabilidade. A influência de parâmetros como o teor de aditivo, a relação água/cimento e o tempo decorrido entre a preparação da pasta e o ensaio podem assim ser avaliados em termos de trabalhabilidade.

17 AÏTCIN, P.-C.; JOLICOUER, C.; MacGREGOR, J. G. Superplasticizers: how they work and why they occasionally don't. Concrete Internacional, v. 16, n. 5, p. 45-52, maio 1994.

18 JIANG, S.; KIM, B.-G.; AÏTCIN, J.-C. A practical method to solve slump loss problem in PNS superplasticized high-performance concrete. Cement, Concrete and Aggregates, v. 22, n. 1, p. 10-15, jun. 2000.

${ }^{19}$ KANTRO, D. L. Influence of water-reducing admixtures on properties of cement paste: a miniature slump test. Cement, Concrete and Aggregates, v. 2, n. 2, p. 95-102, 1980.

${ }^{20}$ BUCHER, H. R. E. Desempenho de aditivos redutores de água de alta eficiência em pastas, argamassas ou concretos. In: Reunião Anual do IBRACON, 30., 1988, Rio de Janeiro. Anais... São Paulo: IBRACON, 1988. p. 609-625. 
Segundo Gomes ${ }^{21}$ (2002), apud Castro (2007) este ensaio tem como vantagens a utilização de equipamento leve, barato, portátil, de fácil manutenção e que permite execução rápida, simples e com pouco consumo de material. Em contrapartida é pouco aplicável em pastas de baixa fluidez.

O ensaio do cone de Marsh, utilizado inicialmente em ensaios de fluidez de grautes, lamas e natas de cimento (CASTRO, 2007), consiste na determinação do tempo que certo volume de pasta de cimento leva para escoar através de um funil com dimensões e abertura padronizadas. Este tempo é relacionado à trabalhabilidade da pasta. Quanto menor o tempo, maior é a trabalhabilidade. Pode-se avaliar a influência dos mesmos parâmetros do ensaio de miniabatimento.

Segundo Gomes $^{21}$ (2002) apud Castro (2007) este ensaio tem como vantagens a necessidade apenas de um equipamento simples e portátil, uso de pequenas quantidades de material e procedimento fácil. As desvantagens se referem à influência da rugosidade da superfície do cone e impossibilidade de avaliação de pastas com baixa fluidez.

Com estes ensaios pode-se determinar o ponto a partir do qual um aumento de aditivo não traz mais ganhos de trabalhabilidade. Este ponto é denominado de ponto de saturação. Além de ser um ponto de interesse comercial, impedindo custo desnecessário, evita também dosagens excessivas que podem levar a problemas de retardo de pega e incorporação de ar (AITCIN, JOLICOEUR e MacGREGOR ${ }^{17}$, 1994, apud CASTRO, 2007).

Além do teor máximo de aditivo pode-se ainda com estes ensaios avaliar a perda de ação do aditivo com o passar do tempo e também a influência de ordem de mistura.

\subsubsection{Melhoria da zona de interface e refinamento da estrutura de poros}

Para obter concretos de melhor qualidade, além da melhoria da matriz cimentícia do concreto, é necessário também melhorar a zona de interface entre a matriz e os agregados. O uso de superplastificantes para reduzir ao máximo a água disponível ajuda também a reduzir a porosidade da zona de interface. Adicionalmente o uso de adições minerais é especialmente indicado para melhorar as propriedades desta região e refinar a estrutura de poros da pasta de cimento. Ollivier, Maso e Bourdette (1994) citam dois fatores que atuam concomitantemente e permitem o desenvolvimento de uma microestrutura melhorada: (1) a

${ }^{21}$ GOMES, P. C. C. Optimization and characterization of high-strength self-compacting concrete. 2002. 139 f. Tese (Doutorado) - Escola Técnica Superior D’Enginyers de Camins, Canals i Ports de Barcelona, Universitat Politècnica de Catalunya, Barcelona, 2002. 
densificação devido ao melhor empacotamento das partículas, caso as adições sejam bem mais finas que os grãos de cimento; e (2) a modificação do processo de hidratação.

O efeito de empacotamento é significativo no caso de adições muito finas, tais como sílica ativa e metacaulinita. O uso de sílica ativa em proporções de 5 a $10 \%$ já é bastante comum na produção de concreto de alto desempenho. A sílica ativa consiste de partículas de sílica amorfa com tamanhos abaixo de $100 \mathrm{~nm}$ (SCRIVENER, CRUMBIE e LAUGESEN, 2004). No caso de adições mais grossas, como é o caso de cinza volante, escória e fíler calcário, que possuem dimensões próximas do cimento, não há o efeito de empacotamento (OLLIVIER, MASO e BOURDETTE, 1994). Efeitos adicionais das adições são a redução da exsudação interna (DAL MOLIN, 2005), segmentação dos poros e homogeneização da pasta por promoverem inúmeros pontos de nucleação para precipitação dos produtos de hidratação (MEHTA e AïTCIN²2, 1990 apud SILVA, 2000).

Dal Molin (2005) lembra que a maioria das adições, pela finura elevada e pela tendência de se aglomerarem, eleva o consumo de água, problema que, no entanto, é perfeitamente resolvido com a utilização de aditivos plastificantes ou superplastificantes, permitindo assim o aproveitamento integral do potencial físico-químico da adição pozolânica.

Além do efeito físico de melhor empacotamento há ainda o efeito químico devido à reação pozolânica que altera o processo de hidratação. As partículas das adições reagem com as partículas de hidróxido de cálcio $(\mathrm{CH})$ que durante a hidratação do cimento se formaram preferencialmente na região mais porosa da zona de interface. O produto desta reação é uma quantidade adicional de silicato de cálcio hidratado (C-S-H). Com isto substitui-se um produto mais frágil e solúvel, e que favorece a micro fissuração devido ao seu formato e orientação, por um produto mais resistente. A adição destes materiais pozolânicos melhora não só a interface da pasta com os agregados, mas, também a pasta como um todo, diminuindo o tamanho e quantidade dos poros. O resultado é um concreto mais resistente e com menor porosidade.

Ollivier, Maso e Bourdette (1994) comentam ainda que o fator principal de ganho de resistência parece dever-se ao empacotamento, pois existem relatos de casos em que o uso de pós finíssimos de alumina não reativa e carbono também demonstraram melhorias de resistência.

22 MEHTA, P. K.; AÏTCIN, P.-C. Principles underlying production of high-performance concrete. Cement, Concrete, and Aggregates, v. 12, n. 2, p. 70-78, jan. 1990. 
É de se esperar também que o resultado da ação pozolânica seja mais intenso nos cimentos que geram um volume maior de $\mathrm{CH}$. Em cimentos que já trazem incorporados grandes quantidades de material pozolânico, apresentando menor teor de clínquer, o efeito pozolânico adicional será reduzido.

Em um concreto com menor consumo de cimento, e, portanto, maior conteúdo de agregados, tem-se maior área superficial de agregados, portanto mais zonas de interface. Surge o questionamento se este aumento não seria prejudicial ao concreto. Em termos de durabilidade, que é fortemente influenciada pelas propriedades de transporte de líquidos e gases no concreto, é de se supor que maior volume de interface seja prejudicial, já que se trata de região mais porosa e com maior conectividade. No entanto, esta avaliação é mais complexa, pois ao mesmo tempo tem-se redução de volume de pasta, que é o componente permeável do concreto, e aumento na tortuosidade do caminho de transporte. Estudos experimentais mostraram que concretos com maior quantidade de agregados e mesma relação água/cimento, são menos permeáveis. (SCRIVENER, CRUMBIE e LAUGESEN, 2004). A presença de maior porosidade e a presença de material mais frágil e solúvel (cristais de $\mathrm{CH}$ ) podem obviamente afetar negativamente o desempenho da zona de transição (OLLIVIER, MASO e BOURDETTE, 1995). Melhorias na zona de transição, decorrentes do uso de aditivos e adições minerais, são muito recomendáveis nos concretos com baixo consumo de cimento.

\subsubsection{Escolha adequada dos agregados}

A importância do agregado para a resistência do concreto tem sido negligenciada, pelo fato da maioria dos agregados possuir resistência muito superior à da matriz e da zona de transição. Há, entretanto, características dos agregados, tais como dimensão, forma, textura superficial e mineralogia, que interferem principalmente nas características da zona de transição, afetando assim a resistência do concreto.

O consumo de água depende da finura dos materiais secos do concreto. Assim, um aumento de granulometria favorece a redução de água. Mehta e Monteiro (2008) ilustram este fato com a Figura 9, relacionando o consumo de água com a dimensão de agregados graúdos. Salienta-se que estes dados são referentes a concreto massa para barragens, onde o uso de agregados de grandes dimensões é viável. 


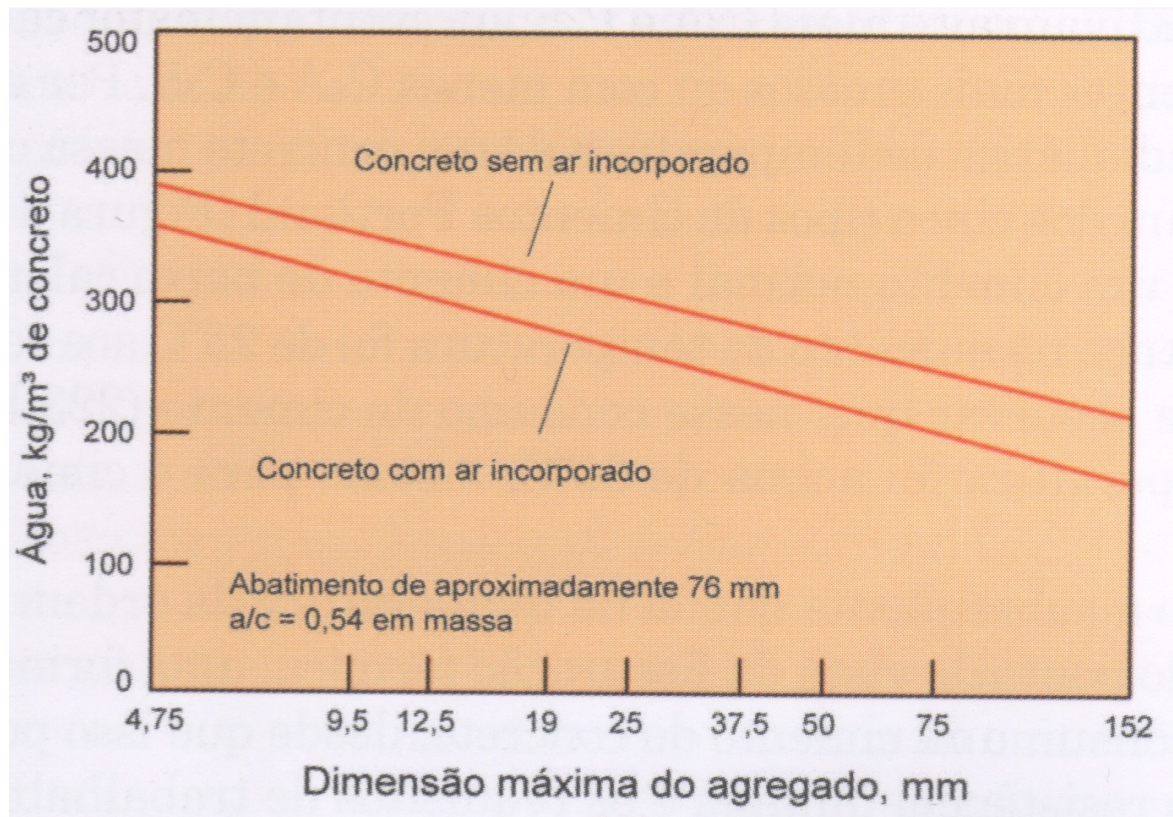

Figura 9 - Relação de consumo de água e dimensão do agregado graúdo. Fonte: Mehta e Monteiro (2008).

Por outro lado, agregados maiores tendem a propiciar a formação de interfaces mais porosas, principalmente na face inferior do agregado. Este fato ocorre preferencialmente em agregados de maiores dimensões ou de formatos achatados. Sob estes a água de exsudação (exsudação interna) e bolhas tendem a se acumular, conforme apresentado na parte superior da Figura 10 (LIBORIO, 2003).

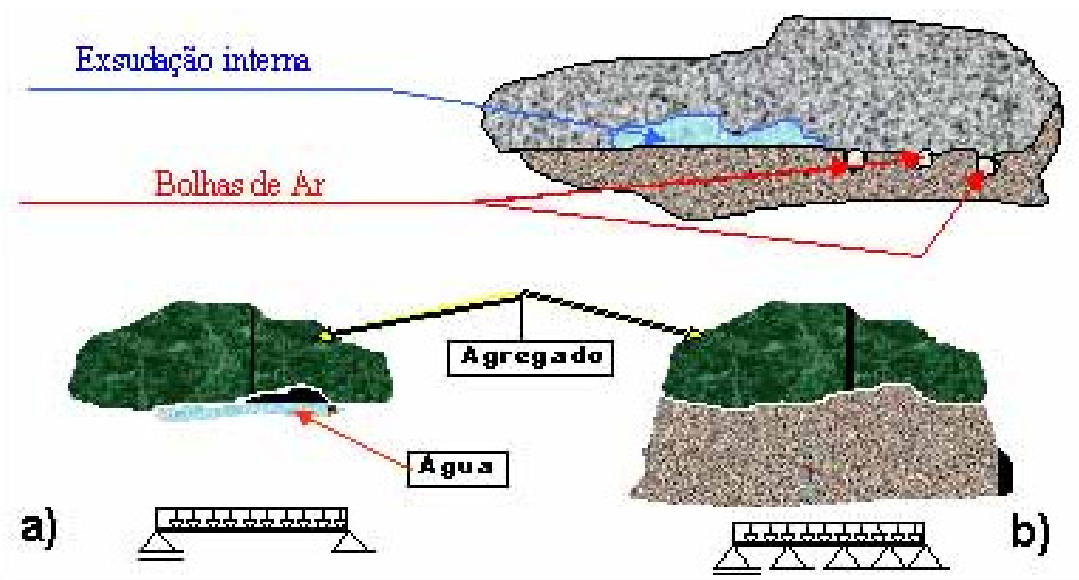

Figura 10 - Idealização do comportamento de agregados com diferentes interfaces devido à exsudação interna.

Fonte: Liborio (2003).

Além de gerar uma região mais porosa, onde se formarão com mais facilidade microfissuras, esta situação pode levar a uma redução de pontos de transferência de tensões do agregado para a matriz. LIBORIO (2003) ilustra esta situação fazendo analogia 
com vigas apoiadas apenas em dois pontos (a - agregado com vazios na face inferior) e em vários pontos ( $b$ - agregados com interface melhorada), conforme a Figura 10. No caso a) as tensões atuantes no agregado serão muito maiores que no caso b) podendo ocasionar ruptura antecipada do agregado, o que reduzirá também a resistência do concreto.

Liborio (2003) cita que a presença de 10 a $15 \%$, em massa, de partículas alongadas é indesejável ao concreto, mas, em algumas situações, não há como não fazer uso delas e assim, quanto mais coeso o material menor será a interferência do agregado, ainda que demande um estudo maior com referência à consistência e trabalhabilidade.

O formato dos agregados tem relação com o consumo de água. É possível obter maior abatimento, para a mesma quantidade de água, com agregados mais finos, porém com um bom índice de forma. Agregados mais angulosos promovem um menor abatimento. Uma maneira de avaliar a angulosidade de agregados miúdos é por meio do índice de vazios. Considera-se que agregados mais arredondados possuem índice de vazios próximo de $33 \%$. Quanto mais angulosos maior será o índice de vazios. Em geral têm-se valores de 0 a $11 \%$ acima deste limite mínimo (LIBORIO, 2003). Ressalta-se que este procedimento vale para agregados com faixa granulométrica não muito variada. Na seção seguinte (2.5.4) mostra-se que é possível obter índices de vazios menores com a combinação de diferentes agregados. Além da redução do consumo de água, em função de menor área específica, partículas mais esféricas atuam como uma espécie de rolamentos entre os grãos maiores, propiciando maior trabalhabilidade para um mesmo consumo de água.

Deve-se acrescentar ainda que, de forma geral, devam ser evitados agregados fracos, altamente porosos ou deletérios (reação álcali-agregado). Caso isto seja economicamente inviável uma alternativa possível a ser avaliada é a mitigação do problema. No caso de agregados com potencial de ocorrência de reação álcali-agregado pode-se recorrer à substituição do cimento ou uso de adições minerais (MEHTA e MONTEIRO, 2008). No caso de agregados fracos, ou altamente porosos, pode-se avaliar a aplicação de técnicas de dopagem, pelas quais se realiza um tratamento superficial ou da porosidade do agregado, podendo obter melhora das características (TRIGO, REBMANN e LIBORIO, 2010).

\subsubsection{Máximo preenchimento do volume do concreto pelos agregados}

Conforme citado anteriormente, a resistência do concreto está intrinsecamente relacionada à sua porosidade. Na busca por um menor consumo de cimento é interessante ocupar o máximo de volume com agregados. Isto é obtido por meio de um processo ao qual 
se dá o nome de empacotamento, definido segundo McGeary ${ }^{23}$ (1961) apud Oliveira et al. (2000, p. 119) como sendo:

"o problema da correta seleção da proporção e do tamanho adequado dos materiais particulados, de forma que os vazios maiores sejam preenchidos com partículas menores, cujos vazios serão novamente preenchidos com partículas ainda menores e assim sucessivamente."

Matematicamente quantifica-se 0 empacotamento pela densidade de empacotamento, definida como o volume sólido em uma unidade de volume total (MEHTA e MONTEIRO, 2008).

As vantagens obtidas por um alto empacotamento, principalmente de agregados graúdos, são citadas por Johansen e Andersen ${ }^{24}$ (1991) apud Koehler e Fowler (2007) como sendo melhorias na resistência, rigidez, fluência, retração por secagem e permeabilidade. De Larrard ${ }^{25}$ (1999b) apud Koehler e Fowler (2007) cita ainda a redução na segregação caso o alto empacotamento seja acompanhado de granulometria contínua e menores diferenças de tamanho entre as partículas das diversas graduações (distribuição sem falhas).

Tomando um conjunto de partículas esféricas de mesmo tamanho (monodispersão esférica) pode-se demonstrar que o máximo de volume que pode ser preenchido em condição ideal é de 74 \%. Na prática, porém, obtêm-se valores inferiores (60 a 64 \%). Caso seja acrescentada a esta dispersão inicial uma quantidade de partículas de dimensões diferentes haverá alteração do volume preenchido. Em alguns casos pode-se atingir um preenchimento próximo a $100 \%$. Para isto, no entanto, é necessário partículas em tamanhos e quantidades adequadas, de modo que as partículas menores preencham da melhor forma possível o espaço vazio deixado pelas maiores. Se forem introduzidas partículas maiores que os vazios deixados, esta introdução provocará o afastamento das partículas existentes, ocasionando novamente um aumento de porosidade. Portanto a distribuição granulométrica do sistema é que irá determinar o grau de empacotamento obtido (OLIVEIRA et al. 2000).

Além da distribuição granulométrica, outros fatores afetam o empacotamento. Oliveira et al. (2000) descrevem estes fatores. A forma, angulosidade e textura do agregado

\footnotetext{
${ }^{23}$ McGEARY, R. K. Mechanical packing of spherical particles. Journal of the American Ceramic Society, v. 44, n. 10 , p. 513-522, out. 1961.

24 JOHANSEN, V.; ANDERSEN, P. J. Particle Packing and Concrete Properties. In: SKALNY, J.; MINDESS, S. (eds.). Materials Science of Concrete II. Westerville, OH: American Ceramic Society, 1991, p. 111-147.

25 DE LARRARD, F. Why Rheology Matters. Concrete International, v. 21, n. 8, p. 79-81, 1999.
} 
afetam o empacotamento, diminuindo a densidade de empacotamento à medida que se afasta da forma esférica. No caso de mistura bimodal de partículas não esféricas observa-se perda mais sensível do empacotamento quando a proporção entre as partículas finas e grossas se desvia do ponto ótimo. O efeito parede, que se constitui em diminuição do empacotamento e aumento de porosidade na proximidade de superfícies grandes, como agregados maiores, fôrmas, incertos e barras de aço, é mais evidente quando a diferença entre a maior e menor partícula é pequena. $O$ efeito parede deixa de ser considerável caso a razão entre os diâmetros for superior a 10. O grau de dispersão das partículas também é importante, principalmente em se tratando de partículas finas que possuem tendência a se aglomerar formando flocos. $\mathrm{O}$ uso de dispersantes é indicado para inibir as forças atrativas entre as partículas, dispersando o sistema e permitindo melhor empacotamento.

A compactação tem grande influência na forma com que as partículas se acomodam. Energias de compactação maiores são preferíveis, pois permitem redução dos vazios e menor variabilidade entre diversas medidas (KOEHLER e FOWLER, 2007).

Um fator de origem prática, que afeta o empacotamento, é a definição de misturas entre dois ou mais agregados disponíveis, visando obter o máximo empacotamento. Devido à variabilidade natural das jazidas há variações na granulometria dos agregados extraídos em posições diferentes, podendo haver alteração na mistura ótima entre eles. Neste caso seria interessante que o empacotamento máximo não seja muito sensível a ligeiras variações dos agregados constituintes.

Na prática há diversas formas de se determinar o melhor empacotamento entre os agregados disponíveis. Uma das opções é o estabelecimento de curvas granulométricas ideais que conduzem a um máximo empacotamento. Tendo-se uma curva destas, basta buscar uma combinação entre os agregados disponíveis de forma a se aproximar o máximo possível desta curva ideal. Técnicas simples de otimização computacional podem ser utilizadas, como exemplificado em Pereira e Liborio (2009). Abordagens mais complexas, que consideram inclusive a compactação, como o Modelo de Empacotamento Compressível (De LARRARD, 1999), podem ser implementadas computacionalmente, como realizado por Formagini (2005). Por fim, uma abordagem experimental simples, baseada na avaliação da compacidade de misturas sequenciais pode ser utilizada no caso de se aplicar o empacotamento apenas aos agregados e não havendo muitos agregados diferentes. A seguir estas abordagens são descritas com mais detalhes. 
Inúmeras distribuições de partículas têm sido propostas para atingir melhores empacotamentos. Já em 1907, Fuller e Thompson ${ }^{26}$ apud Koehler e Fowler (2007) sugeriram uma curva aproximada por uma parábola, conforme a equação:

$$
p_{t}=\left(\frac{d}{D}\right)^{0,5}
$$

em que $p_{t}$ é a porcentagem de sólidos com dimensão inferior a $d$ e $D$ é a máxima dimensão.

Ajustes, baseados em experimentos, foram propostos, tais como a equação sugerida por Bolomey ${ }^{27}$ (1947) apud Koehler e Fowler (2007):

$$
p_{t}=f+(1-f)\left(\frac{d}{D}\right)^{0,5}
$$

em que $f$ é definido conforme a trabalhabilidade requerida, tanto maior quanto maior a trabalhabilidade. Com $f=0$ recai-se na equação anterior. Valores de $f=0,1$ são sugeridos no método de dosagem do INT (Instituto Nacional de Tecnologia), citado por Alves ${ }^{28}$ (1978). Esta distribuição só tem sentido se aplicada para a fase agregado porque impõe um teor mínimo passante (f) além da menor dimensão.

A equação de Fuller posteriormente foi generalizada substituindo o expoente fixo por um expoente $q$ que pudesse variar conforme as condições de ensaio, ficando este modelo conhecido como modelo de Andreasen:

$$
p_{t}=\left(\frac{d}{D}\right)^{q}
$$

$\mathrm{Na}$ indústria de asfalto é comum o uso de $\mathrm{q}=0,45$ (NEVILLE, 1997). No caso particular de $q=0,37$ obtém-se a máxima densidade, segundo Funk e Dinger ${ }^{29}$ (1993) apud Oliveira et al. (2000).

Oliveira et al. (2000) comentam que esta máxima densidade é ideal, não podendo ser obtida na prática, já que não considera a existência de dimensão mínima das partículas. Para corrigir este fato foi desenvolvido o modelo de Alfred:

${ }^{26}$ FULLER, W. B.; THOMPSON, S. E. The Laws of Proportioning Concrete. Transactions of ASCE, v. 59, p. $67-$ 143, 1907.

${ }^{27}$ BOLOMEY, J. (1947) Revúe Matér. Constr. Trav. Publ., ed. C., p. 147.

${ }^{28}$ Embora este autor tenha definido "Y" na página 72 da sua obra como sendo a porcentagem que passa através da peneira de abertura "d", a equação apresentada na página 73, seção VII.1.2.2, refere-se claramente à porcentagem retida, donde se obtém o valor de $f=0,1$.

29 FUNK, J. E.; DINGER, D. R. Particle packing part III: discrete versus continuous particles sizes. Interceram, v. 41, n. 5, p. 332-334, 1992. 


$$
p_{t}=\left(\frac{d-D_{i}}{D-D_{i}}\right)^{q}
$$

sendo neste caso $D_{i}$ o diâmetro inferior da distribuição (menor partícula).

Pereira (2010) ilustra algumas destas curvas discutidas (Figura 11).

Modelos mais elaborados foram propostos recentemente por De Larrard (1999). Este modelo, denominado de Modelo de Empacotamento Compressível (MEC), permite o cálculo da densidade de empacotamento de misturas granulares polidispersas, considerando a interação entre as partículas e o efeito da técnica de compactação (vibração) utilizada. Este método permite também a calibração por meio de dados experimentais. Os resultados do modelo, junto com outras características, podem ser utilizados para prever algumas propriedades do concreto, tais como trabalhabilidade, resistência e potencial de segregação. Por apresentar um volume de processamento matemático mais refinado é interessante programar em um software todos os cálculos necessários. Uma abordagem disto é proposta por Formagini (2005) que detalha o modelo MEC, descreve a implementação computacional e aplica o mesmo para elaboração de concretos de altíssimo desempenho.

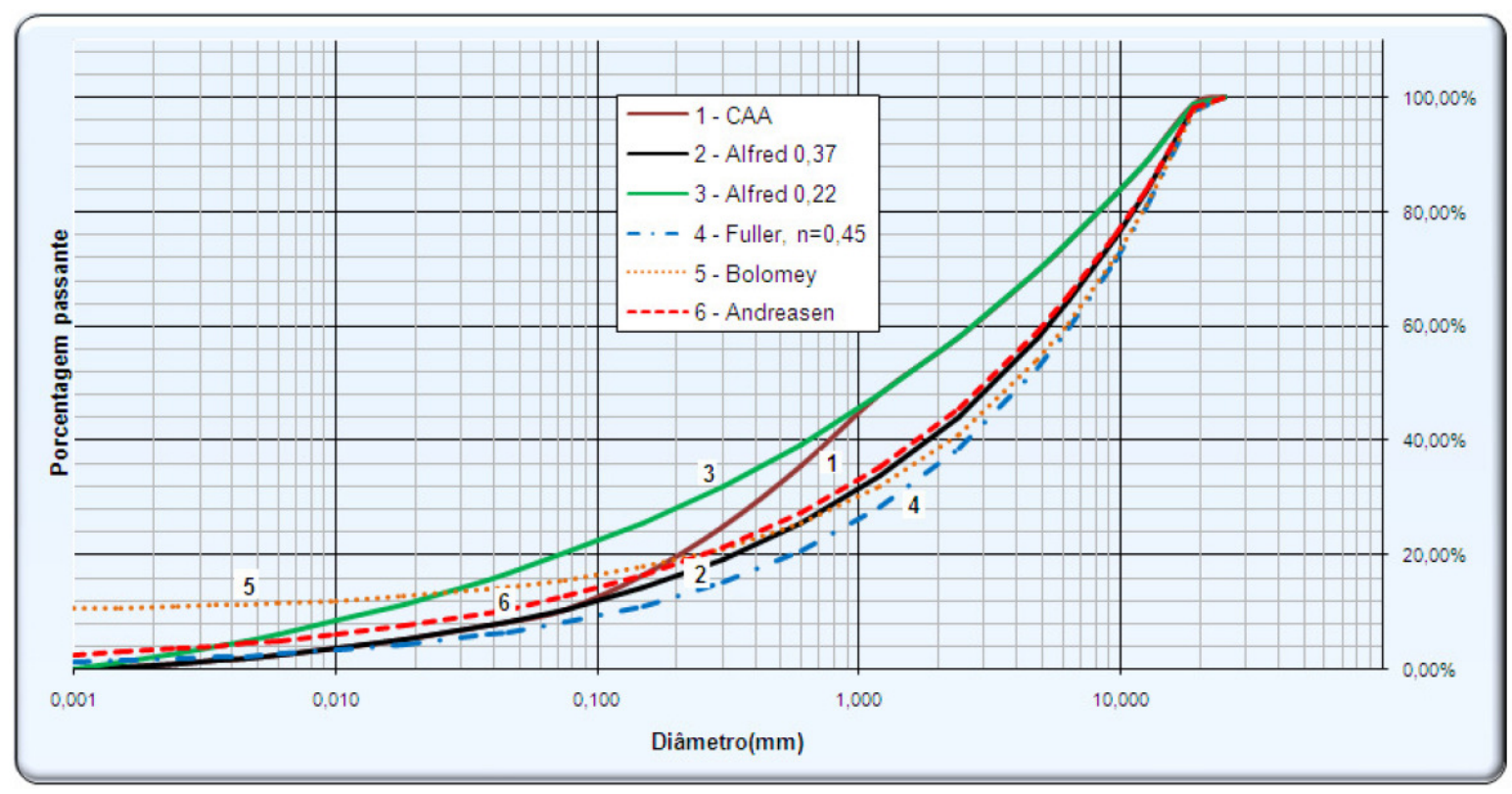

Figura 11 - Diversas curvas granulométricas ideais. Fonte: Pereira (2010).

Opção mais simples para obter um empacotamento de partículas é realizar o empacotamento experimental, também denominado de método das misturas sucessivas. Este método, sugerido por diversos autores e para concretos diversos (HELENE e TERZIAN, 1993; ALVES, 1978; DÍAZ, 1998; TUTIKIAN, 2007), visa realizar misturas 
experimentais entre diversos agregados e calcular o índice de vazios obtido, na busca por minimizá-lo. Em geral parte-se do agregado de maior dimensão e sucessivamente acrescentam-se porções maiores de um segundo agregado. Para cada mistura calcula-se o índice de vazios. Uma vez obtida a mistura que gere o maior empacotamento pode-se utilizar esta mistura e realizar um novo processo com um terceiro agregado, menor ainda, e assim sucessivamente.

As vantagens deste método são que se leva em conta a forma, angulosidade e textura das partículas, que nos métodos teóricos, em geral, são consideradas esféricas. Também se pode reproduzir no ensaio a compactação a ser aplicada no concreto. Em contrapartida não há garantia que este procedimento realmente leve à maior compacidade, já que a mistura em ordem pré-determinada (por exemplo, da maior para a menor partícula) pode não detectar possíveis misturas alternativas que sejam mais compactas. Também se torna muito trabalhoso no caso de se ter muitos agregados diferentes disponíveis.

Há de se salientar que a questão do empacotamento não é aplicável apenas aos agregados, mas pode ser estendida a todas as partículas. Como citado no item 2.5.2, o uso de adições minerais extremamente finas contribui para preencher os vazios deixados pelos grãos de cimento. A consideração dos finos inclusive é recomendada, já que a presença destes pode alterar o empacotamento dos agregados (DE LARRARD, 1999b, apud KOEHLER e FOWLER, 2007). Comparando empacotamentos totais com empacotamentos apenas dos agregados, este autor observou que para compensar a presença dos finos ocorre um aumento da quantidade de agregado graúdo. Caso o estudo de empacotamento seja estendido para estas partículas finas, a abordagem experimental da máxima densidade passa a ser mais complicada, por ser difícil realizar um empacotamento adensável com os pós finos. Alternativas utilizando água, com ou sem aditivos, foram propostos por De Larrard, porém, em geral, prefere-se neste caso utilizar as curvas de distribuição granulométricas ideais ou modelos matemáticos.

Juntamente com a determinação da densidade de empacotamento pode-se calcular o volume de vazios ainda restante após o empacotamento dos agregados. Este espaço vazio restante deve ser preenchido por um volume suficiente de pasta de cimento (KOEHLER e FOWLER, 2007). Volumes inferiores a este produzem concretos mais porosos, com falta de pasta. O volume exato suficiente para preencher os vazios resulta em condição de agregados muito próximos uns dos outros, provocando um embricamento entre os grãos e redução da trabalhabilidade. Segundo Mehta e Monteiro (2008) a busca por um máximo empacotamento passa por considerações de custo, trabalhabilidade, resistência e durabilidade. Advertem que, além de não ser econômico reproduzir uma distribuição 
granulométrica ideal a partir de um conjunto de agregados disponíveis, esta pode não prevalecer na prática do concreto no campo, por levar a um concreto com trabalhabilidade prejudicada.

Um volume de pasta adicional, portanto, é sugerido para dar mobilidade aos agregados e prover um nível mínimo de fluidez (KOEHLER e FOWLER, 2007). Kennedy ${ }^{30}$ (1940) apud Koehler e Fowler (2007), demonstrou que para obter concretos com trabalhabilidade adequada há necessidade de um excesso de pasta em relação aos vazios dos agregados de maneira a diminuir a interferência entre as partículas. Isto é particularmente importante no caso de concretos que não sejam vibrados, como os autoadensáveis. No caso da abordagem por curvas ideais, ajustes no coeficiente $q$ são recomendados. No caso da distribuição de Alfred sugere-se a redução de $q=0,37$ (máximo empacotamento) para $q=0,22$ (máxima fluidez). Há ainda sugestões de buscar um máximo de empacotamento apenas para a fração fina e um máximo de fluidez para a fração grossa, ideal para produção de concretos autoadensáveis (PEREIRA, 2010). Wong e Kwan (2005) sugerem que a transição entre as frações grossa e fina se dê em torno do diâmetro de 1,2 mm, já que partículas inferiores a este tamanho tendem a permanecer coesas com a pasta. Na Figura 11 estão também ilustradas as curvas de Alfred para $q=0,22$ e a curva híbrida para concretos autoadensáveis (CAA).

O uso de altas densidades de empacotamento, aliadas ao emprego de sílica ativa e superplastificantes, já está sendo praticado comercialmente na Europa para produção de concretos de alta resistência, chegando a resistência à compressão superior a $200 \mathrm{MPa}$ (MEHTA e MONTEIRO, 2008). Estes autores ainda comentam que os métodos de dosagem atuais dão ênfase principal à relação entre resistência e o fator água/aglomerantes. Quando esta ênfase mudar para uma relação entre durabilidade e consumo de água, haverá o incentivo necessário para incorporação dos conceitos de empacotamento de partículas nos métodos de dosagem de concreto.

\subsubsection{Procedimento e eficiência da mistura}

A relação entre o processo de mistura e as características do concreto pode ser avaliada com base principalmente nos aspectos de homogeneidade e trabalhabilidade da mistura obtida.

${ }^{30}$ KENNEDY, C. T. The Design of Concrete Mixes. Journal of the American Concrete Institute, v. 36, n. 2 , 373-400, fev. 1940. 
Uma mistura inadequada gera concreto heterogêneo, com propriedades variando dentro da mesma betonada. Problemas com heterogeneidade podem prejudicar a resistência estimada para um lote de concreto, já que esta é determinada basicamente pelos piores resultados obtidos ${ }^{31}$. Mesmo em um único corpo de prova pode haver prejuízo, pois a resistência de um material em geral está relacionada à maior falha presente, fato agravado pela heterogeneidade. $\mathrm{O}$ uso de um concreto com adequada trabalhabilidade reduz também a chance de formação de vazios por ar aprisionado, permitindo melhor adensamento e acabamento.

Segundo Castro (2007) em condição de mistura ideal o material deve estar isento de aglomerados, cada partícula deve estar envolvida com água e a mistura deve apresentar baixa viscosidade. Uma mistura homogênea de materiais à base de cimento pode ser obtida por um processo de mistura que forneça tensão suficiente para quebrar esses aglomerados.

Como a quantidade de água, ou fator a/c, está intimamente ligada à resistência, e a quantidade de água é também relacionada à trabalhabilidade do concreto, qualquer ação tomada em direção a melhorar a trabalhabilidade, sem aumento de água, pode também ser interpretada como a manutenção da trabalhabilidade com redução de água, proporcionando assim ganho de resistência. Ganhos de trabalhabilidade obtidos graças a ajustes na ordem de mistura, desde que não interfiram muito no tempo total de mistura, podem representar ganhos de desempenho da mistura com praticamente nenhuma alteração de custos.

Relacionar a trabalhabilidade com o processo de mistura de um concreto é importante na medida em que possibilita avaliar as exigências de energia em usinas de concreto, controlar a qualidade na produção de concreto e estudar a eficiência de misturadores específicos (TATTERSALL e BANFILL ${ }^{32}$, 1983, apud CASTRO, 2007).

O estudo da influência de diferentes energias de mistura sobre o comportamento de materiais à base de cimento, em geral, é realizado em termos qualitativos. Yang e Jennings (1995) observaram que misturas produzidas em misturadores de alta velocidade apresentaram tensão de escoamento e viscosidade plástica menores do que aqueles produzidos segundo os procedimentos estabelecidos em normas. Portanto, o escoamento desses materiais é sensível à história do cisalhamento e à intensidade de mistura.

31 Já se tornou comum nas empresas prestadoras de serviço de concretagem, o controle do concreto por amostragem total, onde há ensaio de exemplares de cada amassada. Os lotes normalmente são formados por menos de 20 exemplares. A ABNT NBR 12.655:2006 prevê nesta situação (alínea 6.2.3.2-a) que a resistência estimada do lote é igual à resistência do exemplar de menor resistência. Mesmo no caso de controle por amostragem parcial, no caso de menos de 20 exemplares por lote, apenas as menores resistências são consideradas no cálculo da resistência estimada (alínea 6.2.3.1-a).

${ }^{32}$ TATTERSAL, G. H.; BANFIL, P. F. G. The rheology of fresh concrete. London: Pitman, 1983. 347 p. 
Não somente os aspectos relacionados ao misturador, mas também a ordem como se processa a mistura, influenciam o grau de uniformidade, a fluidez e a trabalhabilidade do concreto (TATTERSALL e BANFILL ${ }^{32}$, 1983; TATTERSALL ${ }^{33}$,1991b; apud CASTRO, 2007) (AGULLÓ et al., 1999). Chiocchio e Paolini (1985), por exemplo, observaram que o melhor momento para adicionar superplastificantes à base de condensados de naftaleno sulfonado e de sais de melamina sulfonados é no início do período de dormência da hidratação do cimento, obtendo-se com isso maior plasticidade e menores perdas com o tempo.

Castro (2007) comparou seis procedimentos diferentes de mistura onde variou a ordem e o instante de colocação dos materiais, mantendo, porém, o tempo total de mistura fixo. Avaliou em seguida a trabalhabilidade por meio de ensaio de abatimento de tronco de cone e consistômetro de Ve-Be ao longo do tempo, até 2 horas após a mistura, avaliando assim não apenas a trabalhabilidade inicial, mas também a perda ao longo do tempo. Observou que a trabalhabilidade variou conforme o tipo de cimento e do tempo decorrido desde a mistura. Conclui assim, que dependendo do tempo disponível para aplicação do concreto, um determinado procedimento pode ser mais adequado que outro.

\subsubsection{Tipos de cimentos}

A relação entre tipo de cimento e as propriedades do concreto depende da constituição físico-química do cimento e da evolução do processo de hidratação.

A finura e a distribuição granulométrica do cimento têm importância vital para o comportamento reológico e o desenvolvimento do desempenho mecânico do concreto. Embora a resistência final de um cimento totalmente hidratado independa da finura original, a velocidade com que se chega a esta resistência está diretamente ligada à finura (KIHARA e CENTURIONE, 2005). Cimentos mais finos desenvolvem maiores resistências a menores idades. Cimentos mais grossos, além de possuírem hidratação mais lenta, podem apresentar parte das partículas que jamais hidratam, mesmo em idades muito avançadas. Partículas maiores que $50 \mu \mathrm{m}$ são praticamente como agregados. Taylor (1990) apresenta relação entre o tempo e a profundidade de hidratação (Tabela 2).

O cimento é um material relativamente caro, quando comparado aos demais componentes básicos do concreto. Utilizá-lo apenas como fíler é, em geral, pouco interessante do ponto de vista econômico.

\footnotetext{
${ }^{33}$ TATTERSALL, G. H. Workability and quality control of concrete. London: E \& FN Spon, 1991. 262 p.
} 
Tabela 2 - Relação entre tempo e profundidade de hidratação de partículas de cimento Portland, sob condições normais de cura.

\begin{tabular}{cc}
\hline Tempo de hidratação (dias) & Profundidade de hidratação $(\boldsymbol{\mu m})$ \\
\hline 1 & 0,43 a 0,47 \\
\hline 7 & 1,7 a 2,6 \\
\hline 28 & 3,5 a 5,4 \\
\hline 150 & 6,1 a 8,9 \\
\hline Difícil & $>45$ \\
\hline Nunca se hidrata & $>75$ \\
\hline
\end{tabular}

Fonte: adaptada de Taylor (1990)

A dificuldade de hidratar completamente o cimento é mais intensa nos concretos de alto desempenho onde a relação a/c é baixa. Taylor (1990) cita que em relações a/c abaixo de 0,38 a hidratação completa do cimento não ocorre. Bentz (2005) investigou a substituição das partículas grossas (acima de $30 \mu \mathrm{m}$ ) de cimento por fíler calcário em pastas e argamassas com baixo consumo de água $(a / c=0,30)$. Observou perdas de resistência apenas em baixas idades, não sendo detectadas diferenças na idade de 56 dias. Estes resultados experimentais já haviam sido previstos em modelagem computacional da hidratação de cimento, realizada por Bentz e Conway (2001).

Kihara e Centurione (2005) consideram como ideal uma faixa de granulometria entre 3 e $30 \mu \mathrm{m}$. O limite inferior é justificado pelos autores pelo fato de partículas abaixo de $2 \mu \mathrm{m}$ pouco influenciarem no aumento de resistência, contribuindo mais expressivamente para o aumento do consumo de água para a mesma trabalhabilidade. A forma da distribuição das partículas entre os extremos também é importante. Uma distribuição mais contínua requer consumo menor de água, pois leva a um melhor empacotamento e assim a menor volume de vazios a ser preenchido com água.

Sobre a presença de partículas não hidratadas, Aïtcin (2000) comenta que nos atuais concretos de alto desempenho, um alto consumo de cimento e baixa relação água/aglomerantes propiciam a existência de razoável reserva de partículas de cimento não hidratadas, que desempenham papel importante no caso de agressões piores que inicialmente previstos, pois o concreto teria uma espécie de poder de autocura. Estas partículas não hidratadas poderiam hidratar se através de uma fissura nova ocorresse a entrada de água. Esta hipótese, no entanto, é bastante questionável, pois pressupõe que a fissura exponha quantidades razoáveis de faces não hidratadas das partículas de cimento, ou seja, é necessário que a fissura rompa as partículas não hidratadas.

Deve-se avaliar se a incorporação de alto teor de material cimentício é viável do ponto de vista econômico e de sustentabilidade ambiental. Yang et al. (2009) descrevem um concreto com poder de autocura. O concreto ensaiado apresentou boas características 
neste sentido, restabelecendo até $100 \%$ de algumas propriedades após processo de dano e autocura. Utilizou-se, porém, consumo de cimento de $578 \mathrm{~kg} / \mathrm{m}^{3}$, além de $694 \mathrm{~kg} / \mathrm{m}^{3}$ de cinza volante, resultando no altíssimo consumo de $1272 \mathrm{~kg}$ de aglomerantes por metro cúbico. Na prática do concreto de alto desempenho os consumos são bem menores. Aïtcin (2000) cita diversas obras onde foi empregado concreto de alto desempenho, com consumos de cimento em geral na faixa de 400 a $450 \mathrm{~kg} / \mathrm{m}^{3}$. É de se avaliar qual a quantidade de cimento não hidratado realmente suficiente para conferir poder efetivo de autocura. Também se deve avaliar se isto é viável do ponto de vista econômico e ambiental.

Além da granulometria, a composição química do cimento interfere tanto na velocidade como na resistência final. O clínquer é formado basicamente pela mistura de fases silicato $\left(\mathrm{C}_{3} \mathrm{~S}\right.$ e $\left.\mathrm{C}_{2} \mathrm{~S}\right)$, aluminato $\left(\mathrm{C}_{3} \mathrm{~A}\right)$ e ferrita $\left(\mathrm{C}_{4} \mathrm{AF}\right)$. Estes compostos não possuem estrutura cristalina pura, possuindo defeitos devido à presença de impurezas (ex: $\mathrm{Mg}, \mathrm{Al}, \mathrm{Fe}$, $\mathrm{Si}, \mathrm{Na}, \mathrm{K}$ e S). Estas falhas presentes em maior ou menor grau levam a estruturas com maiores ou menores vazios estruturais, tornando-os mais ou menos reativos. Os aluminatos possuem muitas imperfeições e são altamente reativos. Já o $\mathrm{C}_{2} \mathrm{~S}$ forma cristais maiores e com menos falhas, sendo menos reativo. Pode-se classificar a reatividade dos compostos do clínquer na seguinte ordem: $\mathrm{C}_{3} \mathrm{~A}>\mathrm{C}_{3} \mathrm{~S}>\mathrm{C}_{4} \mathrm{AF}>\mathrm{C}_{2} \mathrm{~S}$. Assim, a resistência em idades mais baixas está relacionada principalmente ao $\mathrm{C}_{3} \mathrm{~S}$ e $\mathrm{C}_{3} \mathrm{~A}$ e a idades altas com o $\mathrm{C}_{2} \mathrm{~S}$. Este é um dos motivos pelo qual a indústria cimentícia dá preferência a cimentos com maiores teores de $\mathrm{C}_{3} \mathrm{~S}$, pois possibilita aos executores de obras maiores resistências iniciais, fato desejável para incrementar a velocidade de execução das obras, mesmo que possa significar menores resistências finais. (MEHTA e MONTEIRO, 2008).

Analisando a reação química de hidratação das fases silicato observa-se que $\circ \mathrm{C}_{3} \mathrm{~S}$ forma $61 \%$ de C-S-H e $39 \%$ de $\mathrm{CH}$ enquanto que o $\mathrm{C}_{2} \mathrm{~S}$ forma $82 \%$ de C-S-H e $18 \%$ de $\mathrm{CH}$. Como a alta área superficial específica e, consequentemente, a propriedade adesiva da pasta de cimento se deve essencialmente à formação de $\mathrm{C}-\mathrm{S}-\mathrm{H}$, a resistência final $\operatorname{com}_{3} \mathrm{~S}$ é menor que com $\mathrm{C}_{2} \mathrm{~S}$, fato confirmado por várias pesquisas (MEHTA e MONTEIRO, 2008). Estes autores também confirmam esta análise teórica por meio de comparação de resistências obtidas com concretos elaborados em tipos diferentes de cimento, que possuem diferentes composições em termos de $\mathrm{C}_{3} \mathrm{~S}$ e $\mathrm{C}_{2} \mathrm{~S}$ principalmente, conforme é ilustrado na Figura 12. 


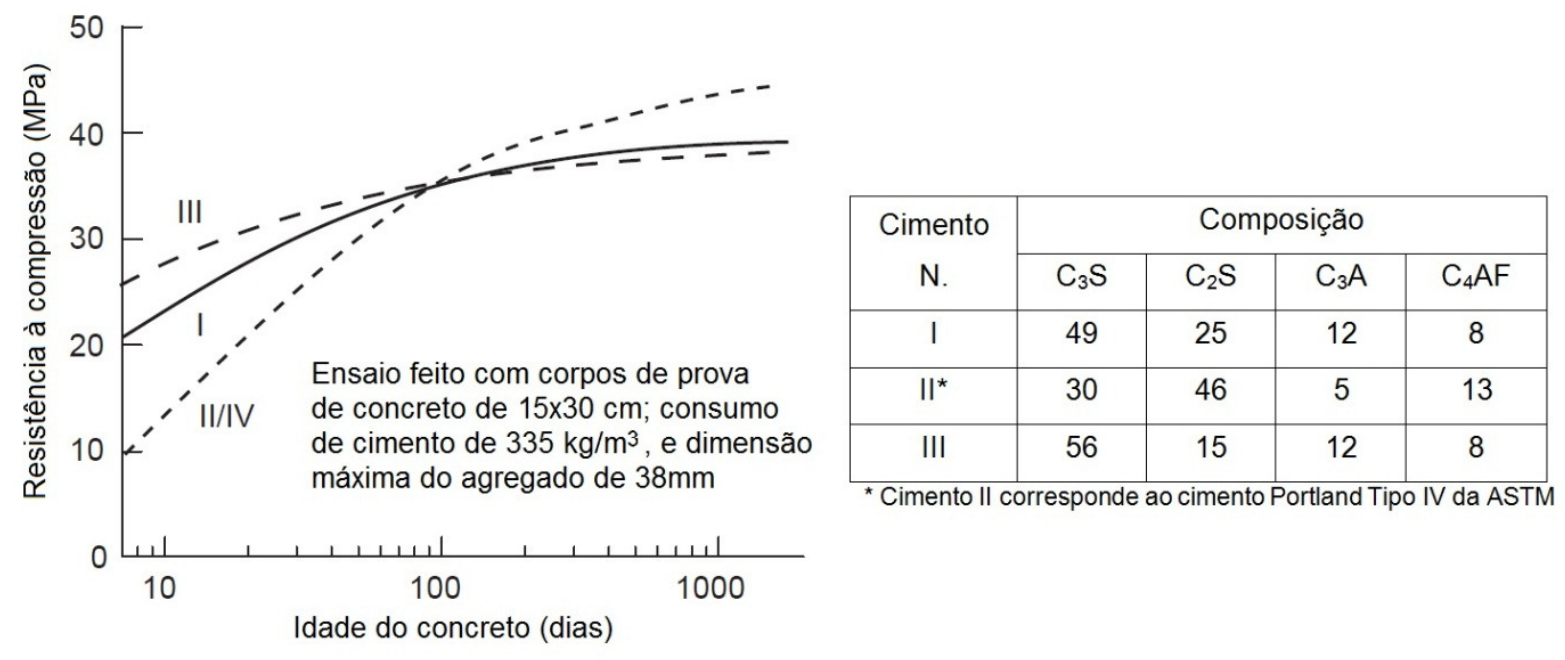

Figura 12 - Influência do tipo de cimento na resistência. Fonte: adaptada de Mehta e Monteiro (2008).

Ainda relativo à reação química pode-se observar que $\mathrm{O}_{2} \mathrm{C}$ forma menos $\mathrm{CH}$, produzindo, por conseguinte, concretos mais duráveis em ambientes ácidos e sulfatados (MEHTA e MONTEIRO, 2008).

Por fim salienta-se que, embora o consumidor do cimento não possa interferir nas características físico-químicas do cimento, determinadas pelo produtor de cimento, é importante ter ciência destas diferenças, pois poderá haver diferenças de desempenho entre tipos e marcas de cimento, e inclusive entre lotes da mesma marca e tipo. Embora este comentário possa parecer evidente, a prática da engenharia nos últimos anos tem demonstrado que as mudanças sistemáticas promovidas pela indústria cimenteira, com alterações de composição e finura, não foram acompanhadas por muitos engenheiros. Graças a estas mudanças maiores resistências podem ser atingidas com menores consumos de cimento e com maiores relações água/cimento, gerando concretos mais porosos. A consequência desta ênfase, quase que exclusiva na resistência, tem levado à degradação acelerada de diversas obras recentes. Uma mudança de foco, de resistência para durabilidade é necessária, e o comportamento do cimento é um dos pontos a ser considerado. 


\section{DURABILIDADE DO CONCRETO}

Nos últimos 20 a 30 anos percebeu-se preocupação crescente entre os engenheiros no sentido de garantir maior durabilidade das estruturas de concreto (DHIR, MCCARTHY e NEWLANDS, 2004). A origem desta preocupação está inicialmente relacionada com os altos custos de reparo e manutenção das estruturas existentes. Mehta e Monteiro (2008) estimam que atualmente nos países desenvolvidos estes custos cheguem a $40 \%$ dos custos da indústria da construção. Mais recentemente a busca pelo incremento da durabilidade passou a fazer parte dos planos de sustentabilidade ambiental. Uma melhoria radical da durabilidade dos materiais é uma estratégica essencial para a busca de sustentabilidade em longo prazo (MEHTA, 2008).

Genericamente a durabilidade de um material pode ser entendida pelo conceito do tempo que este pode ser utilizado antes que se torne impróprio para o fim ao qual se destina. Mais especificamente relativo ao concreto o ACl Committee 201 define como a capacidade de resistir ao intemperismo, ataque químico, abrasão, ou qualquer outro processo de deterioração ( $\mathrm{ACl}$ 201.2R, 2008).

Segundo o CEB, em seu boletim BI 213/214 (1993) (CEB-FIP Model Code 90), uma estrutura de concreto deverá ser projetada, construída e utilizada de forma que, diante das influências ambientais previstas, mantenha condições de segurança, utilização e aparência aceitáveis durante período de tempo implícito ou explícito, sem exigir altos custos de manutenção e/ou reparo.

A ABNT NBR 6118:2003 (p. 13) particulariza o conceito para as estruturas de concreto ao definir que durabilidade "consiste na capacidade da estrutura resistir às influências ambientais previstas e definidas em conjunto pelo autor do projeto estrutural e o contratante, no início dos trabalhos de elaboração do projeto". Mais específico ainda, para edifícios habitacionais, a ABNT NBR 15.575-1:2010 (p. 5) define o termo como "capacidade do edifício ou de seus sistemas de desempenhar suas funções, ao longo do tempo e sob condições de uso e manutenção especificadas, até um estado limite de utilização".

Quando se tratam de estruturas de concreto armado/protendido deve-se ainda distinguir a durabilidade do concreto em si da durabilidade da estrutura. A durabilidade do concreto se refere à manutenção das suas propriedades por determinado período. Já a da estrutura depende não apenas do concreto, mas também do projeto e da execução (COLLEPARDI, 1998). Algumas características particulares do concreto armado podem 
levar à redução da vida útil que inicialmente não seria esperada, dadas as boas características do concreto. Silva (2007) mostrou que vigas de concreto armado submetidas à flexão, executadas com concreto de alto desempenho, podem ter a sua vida útil comprometida devido à penetração de gás carbônico pelas microfissuras que surgem naturalmente em peças fletidas. A carbonatação levou à despassivação e corrosão antecipada do aço nestas regiões, mesmo sendo o concreto de boa qualidade e o ambiente sem agressividade especial.

A durabilidade do concreto, ao contrário do alguns podem pensar, não significa vida indefinida, nem suportar qualquer tipo de ação (NEVILLE, 1997). É necessário definir por quanto tempo e em quais condições o concreto deve atender de forma segura e econômica às condições de uso exigidas.

\subsection{Vida útil}

O conceito de vida útil quantifica o conceito de durabilidade, atribuindo medida temporal. É o período de tempo durante o qual a estrutura cumpre "com os requisitos mínimos de segurança, funcionalidade e aspecto estético que lhe sejam exigidos em função das ações e influências ambientais que se estimem venham a atuar sobre a mesma" (ANDRADE PERDRIX, 1992, p. 89).

O CEB, em seu boletim BI 213/214 (1993), estabelece que a vida útil das estruturas deva ser especificada pelo cliente. Em geral, recomenda período de 50 anos para estruturas permanentes. Entretanto, estruturas especiais podem ser projetadas para períodos maiores e estruturas temporárias para períodos menores.

Vidas úteis de em torno de 50 anos são consideradas comuns e períodos de longa duração de 200 anos ou até mais podem ser especificados em obras de infraestrutura de grande interesse social, como túneis subaquáticos, grandes pontes, sistemas viários, etc., ou de interesse arquitetônico especial, como monumentos, igrejas, edifícios oficiais, etc. (COLLEPARDI, 1998).

Na Europa o Eurocode 0 (CEN EN 1990:2002) fornece a Tabela 3 para estabelecer a vida útil de algumas categorias de construção. 
Tabela 3 - Vida útil de estruturas segundo o Eurocode 0.

\begin{tabular}{ccc}
\hline Categoria & Vida útil & Exemplos \\
\hline 1 & 10 anos & $\begin{array}{c}\text { Estruturas temporárias, exceto aquelas previstas para reuso } \\
\text { após a desmontagem inicial. }\end{array}$ \\
\hline 2 & 10 a 25 anos & Elementos estruturais substituíveis \\
\hline 3 & 15 a 30 anos & Estruturas agrícolas e similares \\
\hline 4 & 50 anos & Edifícios e outras estruturas comuns \\
\hline 5 & 100 anos & Edifícios monumentais, pontes e outras estruturas de \\
grandes dimensões
\end{tabular}

Fonte: CEN EN 1190:2003, tabela 2.1

No Brasil a NBR 6118:2003 (p. 15) estabelece que, "por vida útil de projeto, entendese o período de tempo durante o qual se mantêm as características das estruturas de concreto, desde que atendidos os requisitos de uso e manutenção prescritos pelo projetista e pelo construtor". No entanto, não define modelos para previsão da vida útil, nem estabelece prazos ${ }^{34}$.

Recentemente a ABNT NBR 15.575-1:2008, referente a edifícios habitacionais de até 5 pavimentos, faz considerações a respeito de durabilidade. Nesta a vida útil é considerada como o "período de tempo durante o qual o edifício (ou seus sistemas) mantém o desempenho esperado, quando submetido apenas às atividades de manutenção predefinidas em projeto" (p. 7). Particulariza ainda vida útil de projeto (VUP) como o período a ser preestabelecido na etapa de projeto. Para os elementos estruturais estabelece VUP mínima de 40 anos. No seu anexo C apresenta mais detalhes, sugerindo inclusive o estabelecimento de vida útil superior, como forma de balizar o mercado e otimizar a relação custo/benefício. Sugere, assim, para a estrutura principal (fundações, elementos estruturais tais como pilares, vigas, lajes, e outros, paredes estruturais, estruturas periféricas, contenções e arrimos) vida útil entre 40 e 60 anos e para estruturas auxiliares (muros divisórios, estrutura de escadas externas) períodos de 20 a 30 anos.

A previsão do tempo que uma estrutura irá durar passa pela avaliação das suas características de construção (concepção, projeto, materiais, execução, utilização) e dos problemas patológicos a que é suscetível. Os modelos de previsão baseiam-se assim, em geral, no tempo para o aparecimento das patologias que significam o fim da vida útil e

\footnotetext{
${ }^{34}$ Durante a revisão da ABNT NBR 6118:1978, em algumas versões de projeto da norma atualizada, chegou-se a prever uma definição sobre vida útil: "As estruturas de concreto devem ser projetadas e construídas de modo que, sob as condições ambientais previstas na época do projeto, e quando utilizadas conforme preconizado em projeto, conservem sua segurança, estabilidade e aptidão em serviço durante um período mínimo de 50 anos, sem exigir medidas extras de manutenção e reparo" (Projeto de Revisão da NBR 6118:2000- Texto de Discussão). Após discussão intensa não houve consenso a respeito da fixação de prazos. Assim, devido à falta de um procedimento que pudesse avaliar e garantir um período de vida útil e da possibilidade de existência de categorias de construção que exigissem outras vidas úteis, menores e maiores, na versão definitiva optou-se por não estabelecer valores.
} 
correlacionam este tempo com a evolução de certos fenômenos como a carbonatação, corrosão, penetração de cloretos, etc.

Por ser um dos problemas mais comuns de deterioração de estruturas de concreto, a corrosão tem sido a base de vários modelos. Helene (1993) apresenta a Figura 13, que resume o desenvolvimento da corrosão e a relação com a vida útil. Para fins de projeto, a despassivação deve ser considerada como limite de vida útil, a favor da segurança. O limite real em que se pode utilizar a estrutura é a vida útil de serviço, cujo fim varia de acordo com a tolerância em relação aos diversos sinais de deterioração. A ruptura final da estrutura conclui a vida útil total. A partir do momento de uma vistoria, a qualquer instante da vida útil pode-se contabilizar vidas úteis correspondentes aos limites de serviço ou total.

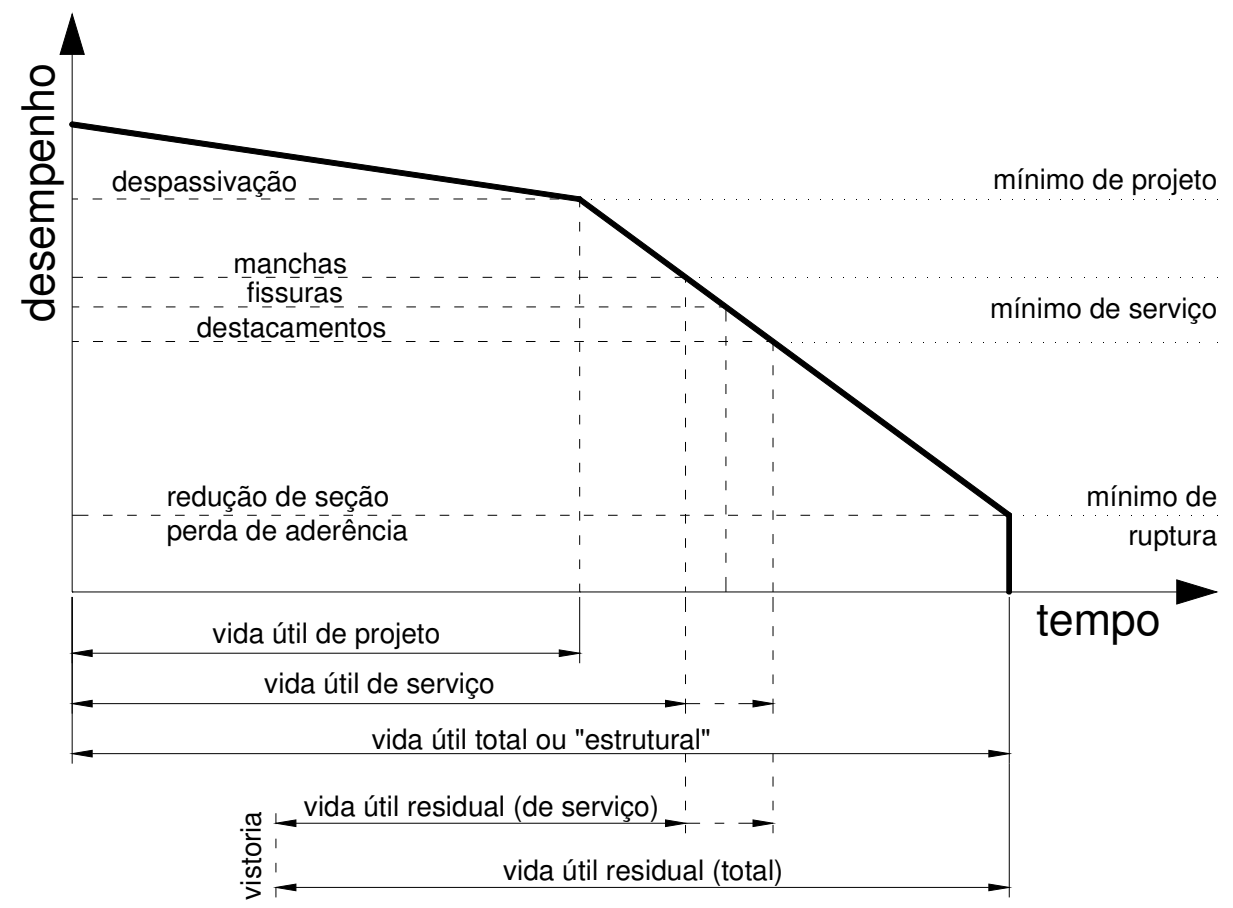

Figura 13 - Vida útil baseada no fenômeno da corrosão das armaduras em estruturas de concreto armado.

Fonte: adaptada de Helene (1993).

Uma ferramenta interessante na avaliação da vida útil é o software Life- $365^{35}$, desenvolvido por consórcio de associações americanas para estimar a vida útil baseado na difusão de cloretos no concreto. Esta ferramenta considera as propriedades do concreto, exposição a cloretos, geometria da peça, cobrimento, temperatura ambiente, proteção

${ }^{35}$ O software Life-365, cuja versão mais recente (2.0.1) foi lançada em setembro de 2009, bem como informação a respeito da utilização, podem ser obtidos gratuitamente em http://www.life-365.org/ . 
superficial, tipos de aço entre outros. Permite, além da estimativa da vida útil, estimar ainda os custos ao longo da vida útil, referente ao custo inicial e também de manutenção e reparos.

Particularmente referente à aplicação de concretos de alto desempenho (CAD) é mais difícil determinar quantos anos uma estrutura irá durar, pois os modelos desenvolvidos para concreto convencional não podem ser automaticamente extrapolados para o CAD e experiências reais em ambientes de alta agressividade ainda são recentes. No entanto é de se esperar que estas estruturas durem pelo menos o equivalente a uma vida humana. (AÏTCIN, 2000).

\subsection{Agressividade ambiental}

A durabilidade do concreto e a vida útil da estrutura dependem além das qualidades do concreto e de fatores de execução também das condições às quais será submetido ao longo da sua vida. Ações de origem mecânica, térmica, de retração e fluência são normalmente consideradas durante o dimensionamento das estruturas. Além destas, outro conjunto de fatores físicos e químicos, relacionado ao ambiente no qual se encontra, age sobre a estrutura promovendo alterações nas suas características. Um mesmo concreto submetido a diferentes condições de agressividade ambiental apresentará durabilidade diferenciada.

De forma resumida agrupam-se os ambientes em basicamente quatro tipos: rural, urbano, marinho e de características específicas.

O ambiente rural apresenta o menor grau de agressividade, com baixas concentrações de $\mathrm{CO}_{2}$ e outros agentes químicos. O ambiente urbano é um ambiente alterado pela presença humana, podendo estar sujeito a chuvas ácidas, deposição de partículas sólidas e maior concentração de gás carbônico e outros gases. Estes fatores propiciam mais rápida degradação do concreto, carbonatação e corrosão das armaduras. Além destes fatores, a alteração geométrica e superficial devido às construções e impermeabilização do solo pode causar alterações na temperatura e direção dos ventos. (LIMA, 2005).

O ambiente marinho é um dos ambientes mais estudados, principalmente por seu elevado grau de agressividade, justificado pela presença de grande quantidade de agentes químicos, físicos e biológicos. Segundo Helene (1993) a velocidade de corrosão em ambiente marinho pode ser 30 a 40 vezes maior do que em atmosfera rural. Caso a 
estrutura esteja submetido diretamente à variação do nível do mar os danos podem ser ainda mais severos.

Além destes ambientes gerais existem casos específicos onde se deve levar em consideração microambientes específicos. Enquadram-se nestes os casos de esgoto, alguns ambientes industriais (em função dos produtos utilizados nos processos ou o contato direto de produtos estocados, como fertilizantes, açúcar, etc.) e situações específicas como a presença de sais de degelo em regiões de clima frio.

Aïtcin (2000) alerta ainda para o fato particular de que o detalhamento estrutural inadequado pode criar artificialmente condições microclimáticas catastróficas, como, por exemplo, a concentração de agentes agressivos em um ponto específico da estrutura. Neste sentido também uma alteração de uso de uma estrutura de concreto deve considerar a mudança de agressividade devido a esta nova utilização e não somente a avaliação das novas cargas e sobrecargas.

A abordagem em termos de projeto, que é prescrita pelas normas atuais, passa pela definição do ambiente no qual a estrutura será inserida. A partir desta classificação, uma série de prescrições deve ser atendida. Estas prescrições se referem basicamente à resistência à compressão mínima, cobrimento e consumo de cimento mínimos, relação água/cimento máxima, especificação de tipos de cimentos e limitação de presença de alguns materiais na fabricação do concreto. Atualmente as principais recomendações são resistência, cobrimento, consumo de cimento e relação água/cimento.

No Brasil, a introdução do conceito de durabilidade na norma de projeto do concreto ocorreu com a publicação da ABNT NBR 6118:2003, que estabelece quatro classes de agressividade ambiental e as exigências de projeto relativas a cada uma. Posteriormente, com a revisão da ABNT NBR 12.655:2006, estas exigências foram complementadas. Na Tabela 4 apresentam-se estas classes e prescrições para o caso de concreto armado.

Algumas normas internacionais já trazem o conceito de classes de agressividade há um tempo bem maior. Dhir, Mccarthy e Newlands (2004) analisaram a evolução das normas britânicas constatando que já em 1965 havia a previsão de nove tipos de ambiente que se correlacionavam a diferentes resistências do concreto e cobrimento. Em 1972 incorporaramse ainda os conceitos de consumo mínimo de cimento e máxima relação água/cimento. Ao longo destes últimos 40 anos variaram os tipos de classes de agressividade considerados. Atualmente, já no âmbito da norma europeia (CEN EN 206-1), complementada por uma norma britânica (BSI BS 8500:2006), conta-se com 18 condições de exposição ambiental. 
Tabela 4 - Classes de agressividade ambiental e exigências de projeto conforme ABNT NBR 12.655:2006.

\begin{tabular}{cccccc}
\hline Classe & Descrição & $\begin{array}{c}\text { Resistência } \\
\text { mínima } \\
(\mathbf{M P a})\end{array}$ & $\begin{array}{c}\text { Cobrimento } \\
\text { nominal } \\
\text { mínimo }^{(1)} \\
(\mathbf{m m})\end{array}$ & $\begin{array}{c}\text { Consumo } \\
\text { Cimento } \\
\text { mínimo } \\
\left(\mathbf{k g} / \mathbf{m}^{3}\right)\end{array}$ & $\begin{array}{c}\text { Relação } \\
\text { água/cimento } \\
\text { máxima }\end{array}$ \\
\hline I & $\begin{array}{c}\text { Rural } \\
\text { Submersa }\end{array}$ & 20 & 25 & 260 & 0,65 \\
\hline II & Urbana & 25 & 30 & 280 & 0,60 \\
\hline III & $\begin{array}{c}\text { Marinha } \\
\text { Industrial }\end{array}$ & 30 & 40 & 320 & 0,55 \\
\hline IV & $\begin{array}{c}\text { Industrial } \\
\text { Respingos de } \\
\text { maré }\end{array}$ & 40 & 50 & 360 & 0,45 \\
\hline
\end{tabular}

(1) Relativo a pilares e vigas. Para lajes deve-se reduzir $5 \mathrm{~mm}$.

(2) Ambientes quimicamente agressivos, tanques industriais, galvanoplastia, branqueamento de celulose e papel, armazéns de fertilizantes, indústrias químicas.

É interessante comentar que, embora a introdução normativa do conceito de durabilidade seja recente no Brasil, há quase sete décadas Lobo Carneiro (1943) já considerava o conceito de classe de agressividade e especificação de relação água/cimento máxima. Esta recomendação, à frente do seu tempo, é reproduzida na Tabela 5. Notam-se relações água/cimento não muito diferentes das atualmente adotadas.

Tabela 5 - Recomendações de Lobo Carneiro para relação água/cimento em diferentes condições de agressividade.

\begin{tabular}{|c|c|c|c|c|}
\hline \multirow{2}{*}{\multicolumn{2}{|c|}{$\begin{array}{l}\text { Condições de } \\
\text { exposição }\end{array}$}} & Extrema & Severa & Moderada \\
\hline & & $\begin{array}{c}\text { Concreto } \\
\text { imerso em } \\
\text { meio agressivo }\end{array}$ & $\begin{array}{l}\text { Concreto em contato com } \\
\text { água sob pressão. } \\
\text { Concreto alternadamente } \\
\text { em contato com água e ar. } \\
\text { Concreto exposto às } \\
\text { intempéries e ao } \\
\text { desgaste. }\end{array}$ & $\begin{array}{l}\text { Concreto exposto } \\
\text { às intempéries } \\
\text { Concreto } \\
\text { permanentemente } \\
\text { imerso em meio } \\
\text { não agressivo }\end{array}$ \\
\hline \multirow{2}{*}{$\begin{array}{c}\text { Natureza } \\
\text { da obra. } \\
\text { Peças: }\end{array}$} & delgadas & 0,48 & 0,54 & 0,60 \\
\hline & $\begin{array}{l}\text { de grandes } \\
\text { dimensões }\end{array}$ & 0,54 & 0,60 & 0,65 \\
\hline
\end{tabular}

Fonte: Lobo Carneiro (1943).

\subsection{Fatores que afetam a durabilidade}

A deterioração do concreto raramente é devida a uma causa isolada. Muitas vezes é difícil atribuir um problema de deterioração a um fator determinado. (NEVILLE, 1982).

Aïtcin (2000) chama a atenção para o fato de que a natureza, a intensidade e os mecanismos implicados em cada um dos diversos ataques ao concreto podem variar consideravelmente. Além disso, não existe método padronizado ou quaisquer unidades que 
possam avaliar a durabilidade, ficando, portanto, um pouco vaga a expressão "durabilidade do concreto". Mais adequado seria falar em "durabilidades do concreto" (no plural), especificando sempre o tipo de ataque que está sendo considerado.

Aïtcin (2000) separa os agentes agressivos em externos e internos. Cita como principais agentes externos os íons cloreto, $\mathrm{CO}_{2}$, sulfatos, ciclos de congelamento e degelo, bactérias e abrasivos. Como agentes internos são considerados os íons cloreto incorporados na fabricação do concreto e álcalis do cimento no caso de reação álcaliagregado.

Embora as causas de deterioração possam ser simultâneas, uma propiciando outra, ou sendo desencadeantes ou aceleradoras, Mehta e Monteiro (2008) as dividem, para facilitar o entendimento, em físicas e químicas. Na Figura 14 estão sistematizadas as causas físicas e na Figura 15 as de origem química (MEHTA e GERWICK ${ }^{36}$, 1982, apud MEHTA e MONTEIRO, 2008).

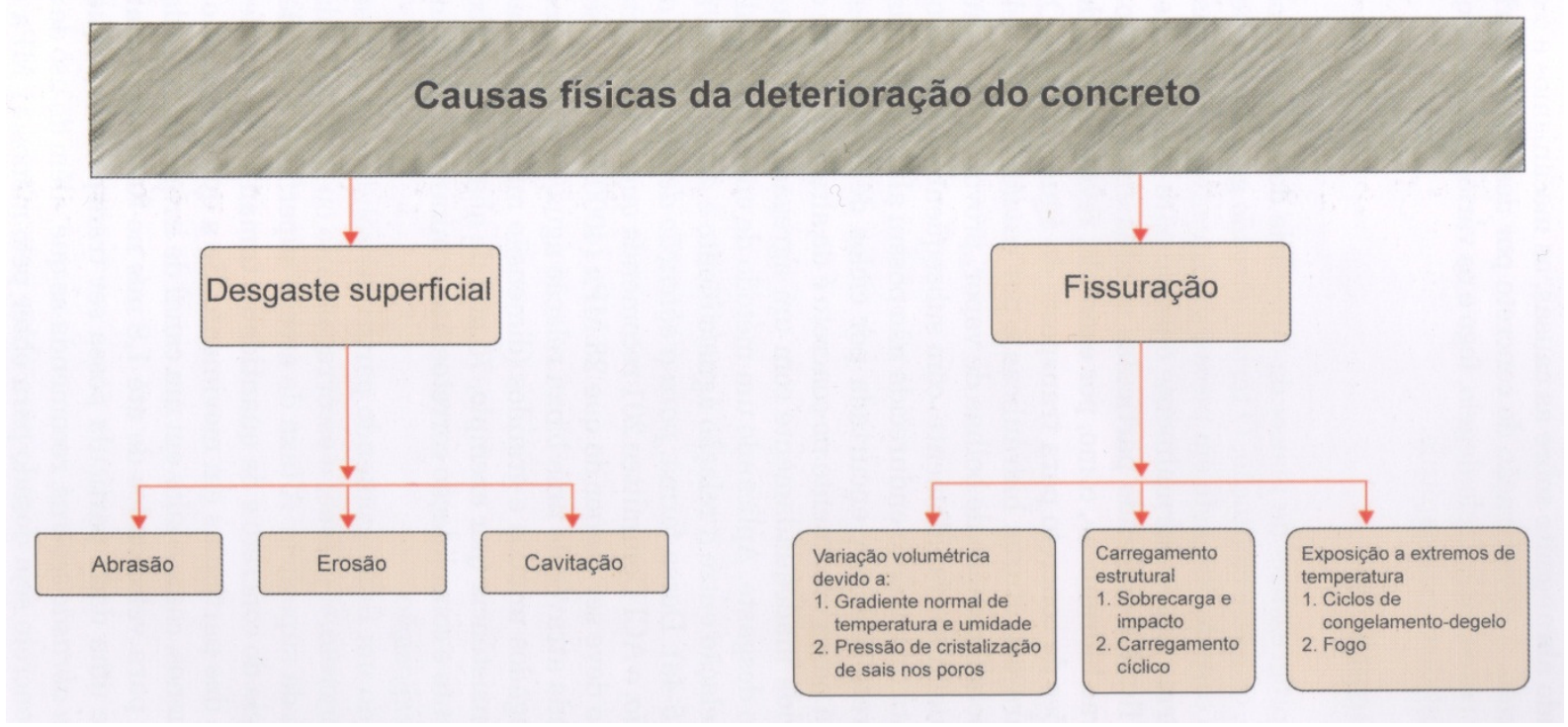

Figura 14 - Causas físicas da deterioração do concreto. Fonte: Mehta e Gerwick ${ }^{36}$ (1982) apud Mehta e Monteiro (2008).

36 MEHTA, P. K.; GERWICK Jr., B. C. Cracking-Corrosion Interaction in Concrete Exposed to Marine Environment. Concrete International, v. 4, n. 10, p. 45-51, out. 1982. 


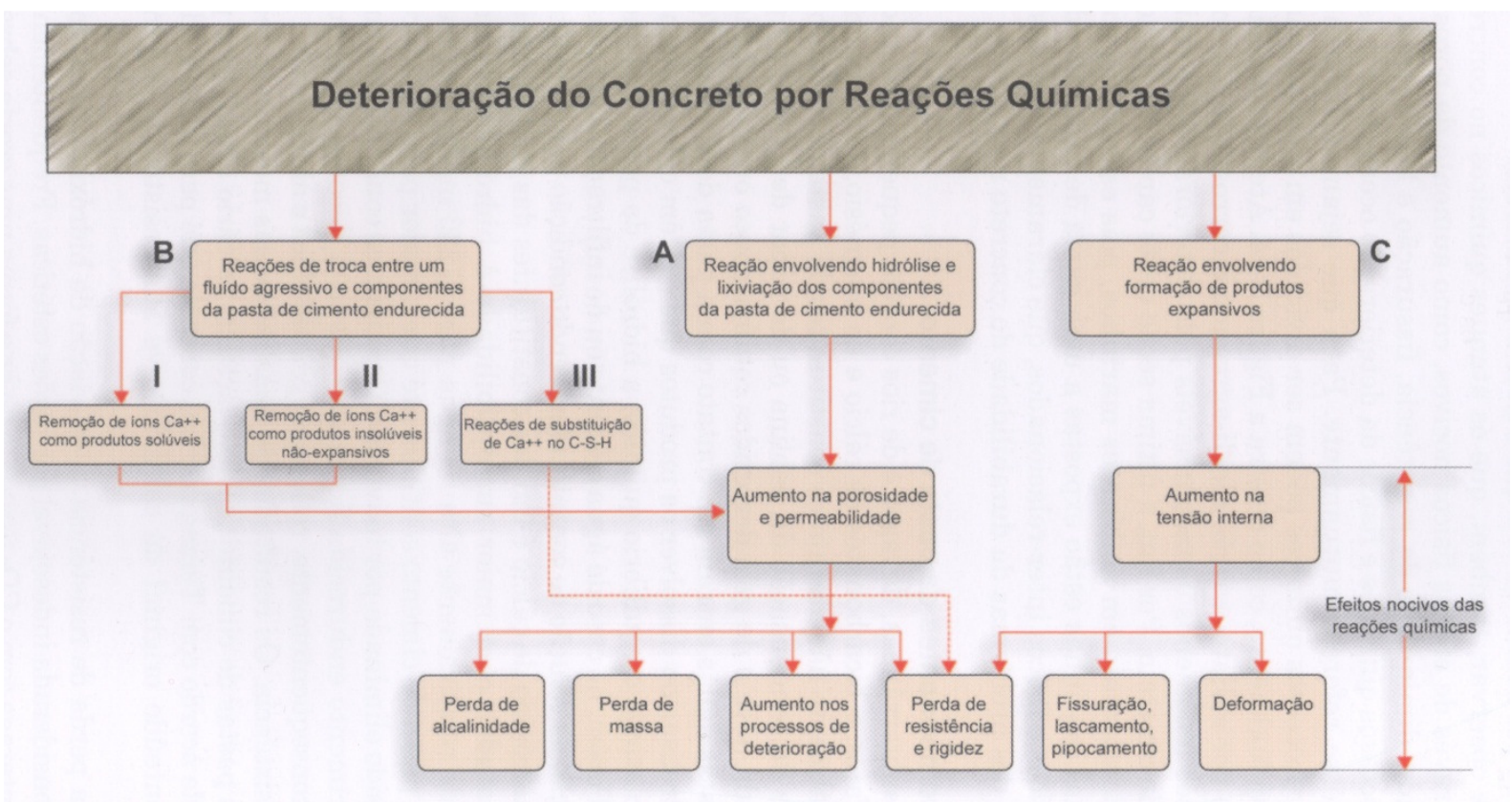

Figura 15 - Causas químicas da deterioração do concreto. Fonte: Mehta e Gerwick ${ }^{36}$ (1982) apud Mehta e Monteiro (2008).

Aïtcin (2000) alerta ainda para fatores durante o lançamento e cura do concreto que podem prejudicar a durabilidade, tais como vibração excessiva, que eleva a porosidade, e exsudação interna, que enfraquece as zonas de transição. Cura inadequada, que possibilita a secagem superficial precoce, propiciando a formação de rede capilar que atinge a superfície, é indesejada, pois estes capilares tornam-se caminho preferencial para o ingresso de agentes agressivos.

Além da presença de compostos agressivos $\left(\mathrm{CO}_{2}\right.$, sais, cloretos, sulfatos, ácidos, etc.) a presença de água é fundamental para a ocorrência da maior parte dos fenômenos de degradação, seja como veículo de condução, seja como solvente, seja como parte das reações químicas ou por meio de fenômenos físicos como a sua expansão ao se solidificar (congelamento) ou gerar alta pressão ao passar ao estado gasoso (fogo).

A água é parte fundamental para a existência do concreto, sendo necessária inicialmente tanto para as reações de hidratação como para dar a plasticidade necessária à mistura. Ao longo da vida do concreto a presença de água passa a ser determinante para a ocorrência de diversos fenômenos, tais como a retração por secagem e fluência e muitos dos processos de degradação. A facilidade que a água tem para penetrar ou sair do concreto é determinante para a ocorrência e intensidade de tais processos. Sendo assim, é de primordial importância o estudo da permeabilidade do concreto. 
Além da penetração de água e agentes agressivos através da estrutura porosa do concreto deve-se ainda salientar que a presença de fissuras oferece caminhos preferenciais de fácil penetração, tendo sido mostrado que a sua existência pode comprometer estruturas executadas com concretos de boa qualidade (SILVA, 2007).

Nas seções seguintes dar-se-á ênfase aos fatores e agressões mais comumente aplicáveis no Brasil.

Não será considerada a ação de gelo/degelo, embora esta situação possa ser encontrada no caso de estruturas de frigoríficos. Um concreto mais denso dificulta a saturação dos poros, reduzindo o problema. A incorporação de microbolhas de ar pode ser necessária ${ }^{37}$.

Também não será detalhada a reação álcalis-agregado (RAA). Concretos suscetíveis devem ser avaliados conforme a reatividade dos agregados e tomadas ações preventivas, como uso de cimento adequado ou substituição dos agregados. Com o uso de menor quantidade de cimento e, portanto, de álcalis, e substituição de cimento por adições minerais, pode-se esperar que a RAA seja menos problemática.

Não será considerada a ação de fogo. Trabalho recente, considerando concreto de baixo consumo de cimento e alta resistência, mostrou que o uso de fibras pode propiciar o escape dos vapores de água gerado em altas temperaturas, minimizando o problema (PEREIRA, 2010).

\subsection{Permeabilidade e porosidade}

Os vazios no concreto, além de reduzirem a resistência (ver seção 2.5), são as portas de entrada e os meios de condução de água e demais agentes agressivos que desencadearão os processos agressivos no interior do concreto. A movimentação de fluidos no interior de um meio poroso, em função de uma diferença de pressão, é denominada de permeabilidade. A permeabilidade mede a facilidade ou a resistência que um meio poroso oferece à passagem do fluido. Deve-se salientar que a movimentação pode acorrer ainda por pressão osmótica (difusão) e pressão capilar (absorção capilar).

\footnotetext{
37 Para maiores informações sugere-se consultar LIMA, S. M. Concreto de alto desempenho aplicado a sistemas de processamento e armazenagem de alimentos em baixas temperaturas. 2008. 155 p. + anexos. Tese (Doutorado). Escola de Engenharia de São Carlos, Universidade de São Paulo, São Carlos, 2008.
} 
Neville (1982) afirma que a permeabilidade é a principal determinante da vulnerabilidade do concreto aos agentes externos, de modo que, para ser durável, um concreto tem que ser impermeável. Ataques superficiais são menos danosos que os ataques que se processam em profundidade. Por isso a permeabilidade é tão essencial. Lixiviação, ataque profundo de líquidos agressivos, penetração de água, oxigênio e cloretos que propiciam a corrosão, penetração do $\mathrm{CO}_{2}$ que propicia a carbonatação, são todos facilitados por maior permeabilidade.

Além da relação com a durabilidade, a permeabilidade ainda pode ter importância funcional, como nos casos de reservatórios de água e barragens (NEVILLE, 1982).

Embora sejam propriedades próximas não se deve confundir absorção com permeabilidade (NEVILLE, 1982). A absorção está ligada à porosidade, isto é, ao volume de vazios (poros) no concreto. Deve-se ainda diferenciar porosidade aberta de porosidade fechada. A porosidade aberta é aquela que possui conexão com as faces do concreto, podendo ser saturada com água, enquanto que a fechada constitui-se de vazios incomunicáveis com o meio externo. A porosidade aberta pode ser medida por ensaios de saturação e secagem.

A permeabilidade no concreto não é uma função simples da porosidade, pois depende também das dimensões, distribuição e continuidade dos poros. Pode-se ter porosidade alta, mas permeabilidade baixa, caso os poros sejam muito pequenos e tortuosos, dificultando a movimentação da água. Pode-se também ter poucos poros, baixa absorção, mas alta permeabilidade se estes poucos poros forem grandes e conectados (NEVILLE, 1982).

A permeabilidade do gel de cimento é extremamente baixa (cerca de $7 \times 10^{-16} \mathrm{~m} / \mathrm{s}$ ). Isto se deve à textura extremamente fina da pasta de cimento endurecida, sendo as partículas sólidas e poros muito pequenos e numerosos. A porosidade de uma pasta de cimento pode ser bem maior (20 a 100 vezes mais) devido à formação de uma rede capilar, através da qual a água flui muito mais facilmente que através dos poros de gel. Nas pastas a permeabilidade depende do grau de hidratação e da porosidade inicial, que é função direta do fator água/cimento utilizado. Um consumo maior de água deixa os grãos de cimento, e posteriormente os produtos de hidratação, mais afastados, formando-se maior porosidade capilar. O processo de hidratação age no sentido de fechar estes vazios iniciais, já que o volume ocupado pelo gel de cimento é aproximadamente 2,1 vezes o volume do cimento não hidratado (NEVILLE, 1982). 
No concreto a permeabilidade depende das características da pasta citadas acima e adicionalmente da interação do fluxo com os agregados. Sendo o agregado de baixa permeabilidade, as partículas deste atuarão como bloqueadores do caminho de passagem da água. Reduz-se a área efetiva de fluxo e aumenta-se o caminho efetivo, já que a água precisa contornar as partículas de agregados. Por outro lado surge a zona de interface da pasta de cimento com os agregados, em geral mais porosa. Conforme já discutido na seção 2.5.3 mesmo assim é de se esperar que concretos que possuam alto empacotamento dos agregados apresentem menor permeabilidade que concretos semelhantes, porém menos empacotados.

A absorção de água é normalmente medida em laboratório por secagem de amostras de concreto e posterior saturação. Este ensaio apresenta algumas dificuldades, pois a secagem em temperatura normal pode não retirar toda água livre, principalmente em concretos de baixa porosidade. Secagem em temperaturas mais elevadas, como a temperatura de $105+/-5{ }^{\circ} \mathrm{C}$ recomendada pela ABNT NBR 9778:2005, também não são adequadas pois podem retirar água combinada dos produtos hidratados. Devido a estas dificuldades e o fato de a absorção não poder ser relacionada diretamente com a permeabilidade, a absorção não pode, portanto, ser usada como medida direta da qualidade de um concreto. Mesmo assim observa-se que grande parte dos concretos de boa qualidade tem absorção bem abaixo de 10 \% (NEVILLE, 1982). Por ser um ensaio relativamente simples de ser executado, algumas recomendações, que relacionam a absorção com durabilidade, têm sido feitas (Tabela 6).

Tabela 6 - Relação entre Absorção de água e Índice de vazios com a qualidade de concreto

\begin{tabular}{|c|c|c|c|}
\hline \multirow{2}{*}{$\begin{array}{c}\text { Qualidade do } \\
\text { Concreto }\end{array}$} & \multicolumn{2}{|c|}{ Absorção } & Índice de vazios \\
\hline & CEB & Helene & Andrade Perdrix \\
\hline Boa & $<3 \%$ & $<4,2 \%$ & $<10 \%$ \\
\hline Média & 3 a $5 \%$ & 4,2 a $6,3 \%$ & 10 a $15 \%$ \\
\hline Pobre & $>5 \%$ & $>6,3 \%$ & $>15 \%$ \\
\hline
\end{tabular}

Fontes: CEB ${ }^{38}$ (1998) e Helene ${ }^{39}$ (1983) apud Silva (2006); Andrade Perdrix (1992).

A permeabilidade pode ser determinada em laboratório por ensaio simples onde se impermeabiliza as laterais de corpos de prova e se aplica pressão sobre um dos topos, medindo o fluxo que atravessa até o outro lado após atingir regime de fluxo constante. Os resultados são, em geral, apenas comparativos (NEVILLE, 1982). Por exemplo, o fluxo de

${ }^{38}$ CEB - COMITÉ EURO-INTERNATIONAL DU BÉTON. Bulletin 192: Diagnosis and Assessment of Concrete Structures: State of the Art Report. CEB: Lausanne/Switzerland, jan. 1998.

39 HELENE, P. R. L. La Agressividad del Médio y la Durabilidad del Hormigón. Hormigón, AATH, Buenos Aires, n. 10 , p. 25-35, 1983. 
água em um concreto com a/c de 0,70 pode ser facilmente medido, mas em relações $\mathrm{a} / \mathrm{c}$ de 0,40 o fluxo praticamente cessa, independente da espessura e pressão aplicada (AÏTCIN, 2003).

Outro ensaio simples, que não encontra normatização e é voltado para a determinação rápida de permeabilidade em campo sem extração de amostras foi utilizado neste trabalho, com procedimento detalhado na seção 4.5.6. As dificuldades neste ensaio estão em garantir que não haja vazamentos superficiais entre o aparelho e o concreto. Uma série de medidas tomadas e explicitadas no procedimento executivo visou garantir melhores resultados neste ensaio. Outra crítica é referente à profundidade e direção de fluxo, já que não se pode garantir um fluxo paralelo e, por se tratar de ensaio rápido, não é possível considerar a efetiva profundidade de fluxo. No entanto, é possível obter resultados comparativos.

Numericamente a permeabilidade é expressa pelo coeficiente de permeabilidade, $\mathrm{K}$, dado pela equação de Darcy:

$$
\frac{d q}{d t} \cdot \frac{1}{A}=K \cdot \frac{\Delta h}{L}
$$

sendo $\frac{d q}{d t}$ a vazão de água, " $A$ " a área da seção transversal do corpo de prova, $\Delta h$, a coluna de água (pressão) e $L$ a espessura do corpo de prova.

\subsection{Ação de cloretos e corrosão da armadura}

A importância do estudo da ação de cloretos no concreto está relacionada basicamente com a corrosão da armadura. A penetração de íons cloreto é provavelmente o fenômeno mais devastador que atinge as estruturas construídas com concreto usual. Atingindo as armaduras, levam a processo acelerado de corrosão. A corrosão se processa com a produção de produtos expansivos, gerando inicialmente microfissuras que permitem o ingresso adicional de cloretos, acelerando o processo que avança até o lascamento do cobrimento. Isto permite a exposição do aço a corrosão ainda mais acelerada, levando a um rápido fim da vida útil do elemento atingido (AÏTCIN, 2000).

As principais origens de íons cloreto são os produtos que entram em contato com o concreto (produtos de limpeza, como ácido muriático; produtos que fazem parte de processos de produção, como no branqueamento de celulose e papel), a água do mar e os respingos e névoa relacionados ao ambiente marinho, sais de degelo a base de cloretos, uso de água de amassamento contaminada, agregados de origem marinha, contato com 
água ou solo contaminado e, embora pouco utilizados atualmente, aceleradores de pega a base de cloretos (SILVA, 2006; FIGUEIREDO, 2005).

A maioria dos problemas gerados pelos íons cloretos é provocada pelo ingresso dos cloretos do ambiente marinho. Lima (2005) divide este ambiente em diversas zonas que se caracterizam pelo distinto acesso a oxigênio, água e umidade. A zona de atmosfera marinha recebe cloretos através da névoa carregada pelos ventos. Há estudos que relatam incidência considerável até distâncias de $700 \mathrm{~m}$ da orla (Meira ${ }^{40}, 2004$, apud Lima, 2005). A região onde ocorre ação direta do mar devido a ondas e respingos é denominada de zona de respingos. Na zona de variação de marés há alternância entre períodos submersos e de contato com o ar. Todas estas três zonas são altamente suscetíveis à corrosão graças à presença de cloretos, além de ações específicas como ação biológica, erosão devido às ondas e ataques químicos de sais agressivos. Uma última região é a zona submersa de forma permanente, onde a corrosão por cloretos é menor em função da menor presença de oxigênio.

Embora os cloretos já possam estar presentes no concreto durante a sua confecção, nos casos de uso de água de amassamento com excesso de cloretos ou aceleradores de pega a base de cloretos, em geral estes problemas podem ser evitados com um projeto e controle adequados na produção. Uma pequena quantidade inclusive pode ser tolerada. A ABNT NBR 12.655:2006 permite concentrações limites variando de 0,05 a 0,40 \% da massa de cimento, dependendo da situação. Nestas baixas concentrações os aluminatos resultantes da hidratação do cimento são capazes de fixar os íons livres (HANSSON et al. ${ }^{41}$, 1985, apud FIGUEIREDO, 2005).

Os maiores problemas de deterioração ficam então por conta das fontes externas de cloretos. Os fatores que mais influem na velocidade e profundidade de penetração estão ligados, sobretudo, à permeabilidade do concreto, cimento utilizado e nas condições de saturação do concreto.

Os produtos formados a partir da hidratação do $\mathrm{C}_{3} \mathrm{~A}$ são capazes de reagir com os íons cloreto, formando um sal insolúvel. Concretos que utilizam cimentos com maiores teores de $\mathrm{C}_{3} \mathrm{~A}$ são, portanto, mais resistentes à penetração de cloretos (RASHEEDUZZAFAR et al., 1990; AïTCIN, 2000). Consumos maiores de cimento também

40 MEIRA, G. R. Agressividade por cloretos em zona de atmosfera marinha frente ao problema da corrosão em estruturas de concreto armado. 2004. 346 p. Tese (Doutorado). Programa de Pós-Graduação em Engenharia Civil da Universidade Federal de Santa Catarina, Florianópolis, 2004.

41 HANSSON, C.M.; STRUNGE, H.; MARKUSSEN, J.B.; FROLUND, T. The Effect of Cement Type on the Diffusion of Chloride. Nordic Concrete Research, Dinamarca, n. 4, p. 70-80, 1985. 
disponibilizam proporcionalmente maior quantidade de $\mathrm{C}_{3} \mathrm{~A}$ e permitem assim menor taxa de penetração de cloretos livres. No entanto experiências realizadas com cimentos, onde parte do clínquer foi substituída por adições minerais, mostraram que houve redução da difusão de cloretos, graças ao refinamento da estrutura porosa do concreto (PAGE, SHORT e HOLDEN, 1981) (MEIRA ${ }^{40}, 2004$, apud FIGUEIREDO, 2005). Neste sentido, Mangat e Molloy (1992) concluíram que no processo de corrosão de armaduras devido à ação de cloretos, a quantidade de cimento possui insignificante influência sobre a despassivação do aço.

A porosidade do concreto, determinada principalmente pela relação água/cimento e pelos processos de adensamento e cura, tem relação com a velocidade de penetração. Concretos com baixa relação a/c podem ter permeabilidade à água muito reduzida, ficando de difícil determinação por ensaios. Mesmo assim pode ainda haver rede contínua de capilares muito finos e tortuosos interligados. Estes podem ser tão finos que a água não consegue fluir através deles. Porém caso seja realizado ensaio de permeabilidade aos íons cloreto é possível observar que ainda existe pequena permeabilidade. Aïtcin (2000) cita concretos comuns com baixa relação água/cimento $(a / c=0,45)$ onde se obtém passagem de corrente de 3.000 a 5.000 coulomb e, em contrapartida, concretos de alto desempenho com carga entre 100 e 500 coulomb. Nestes a penetração é tão baixa que é quase impossível a ocorrência da corrosão das armaduras de aço.

Vale ressaltar mais uma vez que a presença de fissuração no concreto, assim como na carbonatação, representa um caminho preferencial de penetração. No caso da corrosão, há ainda a agravante que estes pontos se transformam em regiões anódicas, onde ocorrerá a oxidação do aço, devido a diferenças de concentração de cloretos, umidade e aeração.

A corrosão da armadura de aço no concreto se processa de maneira simplificada a partir da ocorrência de algumas condições. Inicialmente é necessária a formação de duas zonas com potenciais diferentes, uma anódica e outra catódica. Esta diferença de potencial pode ser originada pela diferença de umidade, aeração, concentração salina e tensões no concreto ou no aço, entre outros. É necessária a presença de oxigênio na região anódica, para que seja possível a transformação do ferro metálico em óxido de ferro. O processo ainda necessita de duas situações de condução. A primeira é a condução dos elétrons gerados na oxidação do ferro da região anódica para a catódica, onde são reduzidos por oxigênio e/ou hidrogênio dissolvidos. Esta situação é facilmente encontrada já que a própria barra de aço faz o papel deste condutor. A segunda situação é a presença de um eletrólito que completa o circuito no sentido inverso, com a migração de íons do cátodo para o ânodo. 
A água faz o papel deste eletrólito. Na Figura 16 este processo é representado esquematicamente.

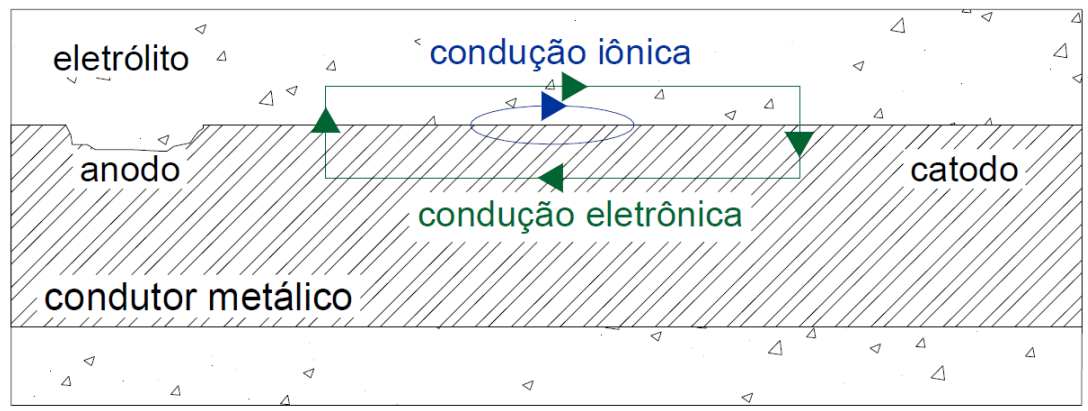

Figura 16 - Representação esquemática de célula de corrosão eletroquímica no concreto armado.

Fonte: Silva (2006).

O concreto, um meio de pH alto (acima de 12,5), fornece condição ideal para manter as armaduras isentas de corrosão, graças à formação de uma camada de óxido superficial estável, denominada de camada passivadora. Para iniciar a corrosão é necessário primeiro destruir esta camada. Isto pode ocorrer com a presença de íons cloreto livres acima de concentrações críticas ou devido à redução do $\mathrm{pH}$ nas proximidades da barra para valores abaixo de 9 , em consequência ao processo de carbonatação (ver seção seguinte). Vale citar que a ocorrência de carbonatação pode liberar parte dos íons cloreto combinados, que passam a ser livres, intensificando o processo (TUUTTI ${ }^{42}$, 1982, apud FIGUEIREDO, 2005).

Os íons cloreto são capazes de destruir a camada passivadora da armadura mesmo em condições de pH elevado (HELENE, 1993). Contribuem assim para a iniciação do processo de corrosão e participam da propagação. O processo químico de corrosão por cloretos não consome estes íons durante a reação, embora participem dele. Ao final da reação os cloretos são novamente liberados, ficando disponíveis para continuar o processo.

Vários ensaios são propostos para avaliar a penetração de cloretos e a corrosão do aço. Para uma análise quantitativa pode-se empregar análises químicas sobre amostras extraídas de diversas posições e profundidades do concreto.

A penetração de íons cloretos é avaliada costumeiramente pelo ensaio descrito na AASHTO T277. Este ensaio consiste em aplicar corrente elétrica a uma fatia de concreto que possui duas faces opostas imersas em soluções diferentes, uma de $\mathrm{NaCl}$ e a outra de

42 TUUTTI, K. Corrosion of steel in concrete. Swedish Cement and Concrete Research Institute, Stockholm, $1982,468 p$. 
$\mathrm{NaOH}$. Os íons cloreto são forçados a migrar através do concreto devido à tensão elétrica aplicada. A medida de penetração é correlacionada com o total de carga que atravessa a fatia em um período de 6 horas. Como a diferença de potencial aplicada é relativamente alta (60 V), em casos de concretos com elevada condutividade, há elevação considerável da temperatura em função do efeito Joule. Há algumas variantes propostas que utilizam diferença de potência menor, elevando em contrapartida o tempo de ensaio.

Apesar das críticas, o ensaio de permeabilidade rápida de íons cloretos (AASHTO T277) dá uma ideia muito boa da interconectividade dos finos poros, mesmo que sejam finos demais para que a água flua através deles. (AÏTCIN, 2003).

Uma forma de visualizar a profundidade de penetração é por meio de aspersão de nitrato de prata sobre uma superfície fraturada do concreto. Nos locais onde há presença de íons cloreto livres ocorre a formação de cloreto de prata de cor branca, contrastando com as demais regiões do concreto onde não há cloretos livres e onde se forma óxido de prata de cor marrom.

Outro ensaio que simula a condição de concreto armado é o ensaio de potencial de corrosão. Um corpo de prova de concreto executado com uma ou mais barras de aço parcialmente embutidas é submetida alternadamente a ambiente seco e ambiente parcialmente submerso em solução de cloreto de sódio. $\mathrm{O}$ uso de ciclos é deletério, pois permitem alternância de presença de oxigênio, água e cloretos. Ao final de cada ciclo de molhagem mede-se a diferença de potencial entre a parte da barra que emerge do concreto e um eletrodo padrão. Diversos eletrodos padrão podem ser utilizados, como, por exemplo, de cobre/sulfato de cobre, prata/cloreto de prata, hidrogênio padrão e colomelano. Conforme o tipo de eletrodo pode-se classificar a situação atual da amostra como tendo determinado potencial de corrosão (Tabela 7).

Tabela 7 - Avaliação da corrosão por meio do potencial de corrosão (diferenças de potencial em $\mathrm{mV}$ )

\begin{tabular}{ccccc}
\hline $\begin{array}{c}\text { Condição de } \\
\text { corrosão }\end{array}$ & $\begin{array}{c}\text { Cobre/Sulfato } \\
\text { de Cobre }\end{array}$ & $\begin{array}{c}\text { Prata/Cloreto } \\
\text { de Prata }\end{array}$ & $\begin{array}{c}\text { Hidrogênio } \\
\text { padrão }\end{array}$ & Colomelano \\
\hline Baixa $(<10 \%)$ & $>-200$ & $>-106$ & $>+116$ & $>-126$ \\
\hline Intermediária & -200 a -350 & -106 a -256 & +116 a -34 & -126 a -276 \\
\hline Alta $(>90 \%)$ & -350 a -500 & -256 a -406 & -34 a -184 & -276 a -426 \\
\hline Severa & $<-500$ & $<-406$ & $<-184$ & $<-426$ \\
\hline
\end{tabular}

Fonte: Broomfield ${ }^{43}$ (1997) apud Silva (2006).

${ }^{43}$ BROOMFIELD, J. P. Corrosion of steel in concrete. St. Edmundbury Press Limited. Great Britain, 1997. 
Uma limitação desta técnica é oferecer somente informação qualitativa aproximada da situação de corrosão ou estado passivo das barras. Os valores indicam apenas o balanço entre a reação anódica e a catódica, não sendo possível obter resultados referentes à velocidade de corrosão da armadura (RIBEIRO, 2010).

\subsection{Carbonatação}

Carbonatação é o processo no qual o gás carbônico presente no ar penetra no concreto por difusão e reage quimicamente com o hidróxido de cálcio - $\mathrm{Ca}(\mathrm{OH})_{2}$ - produzido pela reação de hidratação do cimento. Isto leva à formação de carbonato de cálcio - $\mathrm{CaCO}_{3}$ - e causa a redução na alcalinidade do concreto. Embora haja etapas intermediárias de formação de ácido carbônico e dissolução do $\mathrm{Ca}(\mathrm{OH})_{2}$, o processo global pode ser expresso resumidamente por:

$$
\mathrm{Ca}(\mathrm{OH})_{2}+\mathrm{CO}_{2} \rightarrow \mathrm{CaCO}_{3}+\mathrm{H}_{2} \mathrm{O}
$$

Deve-se salientar ainda que também ocorre carbonatação a partir do C-S-H (TAYLOR, 1990), porém em menor proporção que com o CH, pois o C-S-H é bem menos solúvel em meios ácidos que o $\mathrm{CH}$

O processo se inicia com a transformação do $\mathrm{CH}$ da superfície do concreto e vai avançando para o interior à medida que este vai sendo consumido. Ao atingir a região da armadura de aço a redução do pH permite a despassivação do aço, o que, em condições propícias conduz à oxidação do aço (DHIR, MCCARTHY e NEWLANDS, 2004). Esta relação com a corrosão é o motivo pelo qual muitos modelos de durabilidade consideram o avanço da frente de carbonatação como critério para estabelecer a vida útil do concreto

Nota-se que a carbonatação em si não representa ação agressiva, embora possa contribuir com a retração e causar fissuras superficiais, especialmente em corpos de prova de pequenas dimensões (TAYLOR, 1990). Por outro lado, a reação que transforma o $\mathrm{CH}$ em carbonato de cálcio aumenta a resistência do concreto e reduz a porosidade (SANJUAN e OLMO, 2001; NGALA e PAGE, 1997; TAYLOR, 1990). Isto ocorre graças ao preenchimento dos poros com a calcita, que também é mais resistente que a portlandita. Além disso, a reação gera produtos que ocupam volume $11,8 \%$ superior ao dos reagentes, podendo reduzir a porosidade em até 26 \% (BERTOS et al., 2004, p. ). Pode-se assim obter proteção superficial do concreto pela carbonatação da camada superficial (NEVILLE, 1982; MONKMAN e SHAO, 2010). 
A carbonatação ocorre naturalmente ao se expor o concreto a ar que contém $\mathrm{CO}_{2}$. A concentração de $\mathrm{CO}_{2}$ no ar varia de acordo com o microclima, sendo 0,03\% em ambiente rural ou marítimo aberto, 0,05 a 0,10\%, em lugares fechados, 0,20 \% em garagens e chegando a $1 \%$ em silos de cereais (RICHARDSON ${ }^{44}$, 1988, apud SILVA, 2007). Poucos programas experimentais buscam avaliar a ocorrência de carbonatação em situações naturais. Para a maior parte das situações as concentrações de $\mathrm{CO}_{2}$ são baixas e levam a avanço muito lento da frente de carbonatação, sendo pouco viável serem aplicadas em pesquisas, onde geralmente os prazos disponíveis são reduzidos. Assim, para acelerar o processo, utilizam-se ensaios acelerados, onde a concentração é maior que a encontrada naturalmente.

Os principais parâmetros que interferem no ensaio acelerados são: a concentração de $\mathrm{CO}_{2}$, a umidade do ambiente, a cura do concreto, o formato do corpo de prova e a condição de umidade interna em que se encontra o corpo de prova antes e durante o ensaio. A temperatura, em variações normais $\left(20\right.$ a $\left.40{ }^{\circ} \mathrm{C}\right)$ interfere pouco nos resultados (PAPADAKIS, VAYENAS e FARDIS ${ }^{45}$, 1991, apud PAULETTI et al., 2008). Atualmente não existe ainda normatização nacional, nem tão pouco procedimento de ensaio uniformizado adotado por uma maioria de pesquisadores. Silva et al. (2009) e Pauletti, Dal Molin, e Kazmierczak (2007) realizaram ampla revisão bibliográfica de trabalhos sobre carbonatação publicados nas três últimas décadas e descrevem as variações encontradas nos parâmetros de ensaio.

Para que ocorra a reação de carbonatação é necessário que $\circ \mathrm{CO}_{2}$ e $\circ \mathrm{Ca}(\mathrm{OH})_{2}$ sejam solubilizados. Para tanto é necessário um nível mínimo de umidade nos poros do concreto. Porém se esta umidade estiver em excesso não haverá condições do $\mathrm{CO}_{2}$ se difundir até a região onde há $\mathrm{CH}$ disponível. A umidade relativa do ambiente, portanto, é um fator de grande importância na velocidade da reação. A umidade ideal para acelerar a reação se encontra entre 50 e 80 \% de umidade relativa (ANDRADE PERDRIX, 1992; BERTOS et al., 2004; HELENE ${ }^{39}$, 1983, apud SILVA et al., 2009).

Não apenas a umidade do ambiente, mas também a condição interna do corpo de prova antes e durante o ensaio é importante. Ensaios iniciados com o corpo de prova saturado apresentam baixas velocidades de carbonatação, enquanto os poros estão saturados. À medida que o concreto vai secando a velocidade aumenta. Também corpos de

${ }^{44}$ RICHARDSON, M.G. Carbonation of reinforced concrete: Its causes and management. New York: CITIS Ltd, Publishers, 1988.

45 PAPADAKIS, V. G.; VAYENAS, C. G.; FARDIS, M. N. Fundamental modeling and experimental investigation of concrete carbonation. ACI Materials Journal, v. 88, n. 4, p. 363-373, jul.-aug., 1991. 
prova muito secos têm velocidades iniciais mais baixas, até que se atinja umidade interna mínima necessária. Devido a este fato tem-se recomendado operações de précondicionamento dos corpos de prova antes de iniciar o ensaio acelerado. Estas operações visam estabelecer condição adequada de umidade interna dos poros. Vários métodos são utilizados, como a permanência em ambiente de laboratório sem controle de umidade, permanência em ambiente com umidade controlada ou secagem por tempo determinado.

Um método normatizado é descrito na RILEM TC 116 (1999). O processo consiste em etapa de pré-secagem de uma amostra do concreto a ser ensaiado, com a finalidade de determinar o teor de umidade necessário para atingir o equilíbrio com a umidade de ensaio escolhida. Determina-se então a quantidade de água que o concreto deve perder para atingir a umidade de equilíbrio. A etapa de pré-condicionamento em si consiste em retirar esta quantidade de água dos corpos de prova que serão utilizados no ensaio, por meio de secagem em estufa a temperatura amena $\left(50^{\circ} \mathrm{C}\right)$. Posteriormente os corpos de prova devem ser envolvidos por um invólucro que garanta a selagem e onde devem permanecer tempo determinado para que ocorra a redistribuição e uniformização interna da umidade.

Além de ser um procedimento trabalhoso, e não garantir que todo o corpo de prova esteja realmente com a mesma umidade, o tempo de secagem em estufa pode representar uma espécie de cura térmica, alterando o grau de hidratação do cimento. Caso o concreto seja de baixa porosidade pode-se ter problemas com o tempo necessário para atingir as constâncias de massa necessárias para o processo.

Processo mais simples é prescrito pela CEN EN 13295:2004 e aplicável a argamassas e concretos independente da porosidade. Os corpos de prova devem permanecer em ambiente de umidade de $60 \%$ por um período mínimo de 14 dias ou até que a diferença de massa medida em intervalo de $24 \mathrm{~h}$ seja inferior a 0,2\%. Este procedimento apesar de mais simples também não garante uniformidade de umidade interna, principalmente em concretos pouco permeáveis.

A falta de técnica universalmente adequada é resumida pelas indagações de Pauletti et al. (2008, p. 10):

Mas, deve-se perguntar: "o que se espera desse procedimento?": "que haja uma distribuição homogênea de uma quantidade de água em equilíbrio com um ambiente de dada umidade relativa?" ou "que a condição de ensaio seja igual para todos os corpos-de-prova, mesmo que isso resulte em quantidades distintas de água internamente?" ou "que todas as amostras tenham o mesmo percentual interno de água?" ou "que seja um procedimento de fácil realização?" ou "que represente da forma mais fiel possível o que ocorre na prática?". A resposta a essas perguntas levará ao procedimento de precondicionamento mais adequado aos objetivos do ensaio acelerado. 
A concentração de $\mathrm{CO}_{2}$ influi na velocidade, pois o ingresso se dá por difusão, ou seja, pela diferença de concentração. Há relatos de ensaios desde 1 até $100 \%$ (SILVA et al., 2009). Concentrações muito elevadas levam a condições distantes das naturais, pois a estrutura cristalina de carbonato de cálcio formado é diferente daquela formada em baixas concentrações (SANJUÁN e OLMO, 2001). Além disto, como a reação gera também água, em casos de baixa permeabilidade a estrutura capilar do concreto pode não ser capaz de eliminar esta água para o ambiente, causando assim fechamento dos poros o que reduz o prosseguimento da reação de carbonatação. Na Europa a CEN EN 13295:2004 especifica por esta razão uma concentração de apenas 1 \%. Pauletti, dal Molin e Kazmierczak (2007) concluem que concentrações mais elevadas (saturadas) podem reduzir a velocidade, sendo a frente de carbonatação mais profunda e bem definida em concentrações mais baixas (6\% neste caso). Concluem, porém, que outros percentuais de $\mathrm{CO}_{2}$ devem ser estudados, a fim de estabelecer o mais adequado para os ensaios acelerados de carbonatação.

Quanto ao formato dos corpos de prova tem-se dado preferência aos cúbicos, onde se despreza os cantos, pois desta forma tem-se frentes de penetração que avançam paralelamente. Em corpos de prova cilíndricos, à medida que a frente avança para o centro ocorre a sobreposição de vetores, que pode aumentar a profundidade de carbonatação (KULAKOWSKI, 2002).

Ainda referente ao período de cura do concreto, este influi no processo já que o grau de hidratação e, portanto, a porosidade depende deste tempo. Em estruturas reais, como o processo é lento, haverá tempo suficiente para que ocorra boa parte das reações de hidratação, desde que uma cura adequada em campo seja realizada. Para algumas situações um período de 7 dias é suficiente enquanto que em outros um período maior é necessário. No entanto, ainda não há na literatura consenso sobre os tempos a serem empregados nos ensaios (PAULETTI, 2008).

Uma padronização do ensaio é importante para que se possam comparar melhor os resultados entre diversos pesquisadores. Além disto, estes ensaios acelerados devem ser correlacionados com ensaios de carbonatação natural para que com isso possa-se estabelecer modelos de previsão mais adequados à realidade (PAULETTI, DAL MOLIN e KAZMIERCZAK, 2007).

A execução dos ensaios de carbonatação acelerada é realizada em ambientes fechados (câmaras) onde se devem controlar os parâmetros citados anteriormente. Após a etapa de pré-condicionamento, os corpos de prova são introduzidos na câmara e permanecem até a data de determinação da profundidade de carbonatação. Nesta data provoca-se a ruptura ou lascamento do exemplar de modo a expor uma seção interna. 
Nesta seção faz-se a determinação da profundidade da frente de carbonatação. Esta frente é evidenciada com a aplicação de algum indicador ácido/base como, por exemplo, fenolftaleína ou timolftaleína, sendo o mais comum o uso de fenolftaleína que tem a vantagem de ser fácil de preparar, ter baixo custo e de determinar níveis de $\mathrm{pH}$ mais baixos $(8,0$ a 9,8), compatível com a faixa de pH onde ocorre a despassivação do aço (SILVA et al. 2009). A RILEM (1984) recomenda a utilização de uma solução com 1 \% de fenolftaleína, em $70 \%$ de álcool etílico e 29 \% de água destilada. Essa solução deve ser aspergida, na forma de névoa, na superfície recém-fraturada, tingindo de vermelho carmim apenas a região não carbonatada. Deve-se realizar a medida de profundidade em vários pontos, pois a frente de avanço da carbonatação é em geral irregular.

\subsection{Desgaste superficial}

A degradação superficial do concreto, de origem física, consistindo de perda progressiva de massa, é denominada de desgaste superficial, sendo subdividida em três tipos: abrasão, erosão e cavitação (MEHTA e MONTEIRO, 2008). No ambiente terrestre têm-se a abrasão, ocasionada pelo atrito seco entre a superfície de concreto e partes móveis, como as devido ao tráfego de veículos e pessoas, movimentação de equipamentos ou ainda devido ao vento. Este atrito provoca a gradual perda de material da superfície do concreto (ANDRADE, 2005). A erosão e cavitação ocorrem em meio aquoso, sendo a primeira devido ao atrito de partículas sólidas carregadas pela água em movimento e a segunda devido ao surgimento de bolhas de vapor d'água em condições de baixa pressão em fluxos de alta velocidade. Quando estas bolhas atingem local de maior pressão ocorre o seu colapso, com a liberação de ondas de choque de alta energia que podem provocar altas tensões e danos em superfícies próximas.

A consideração de abrasão é importante principalmente em projetos de pisos industriais e rodovias de pavimento rígido, sobretudo em áreas de manobra e aceleração/frenagem, como pontos de parada de ônibus e praças de pedágio. Desgaste demasiado é indesejado do ponto de vista de funcionalidade (estética, segurança, produtividade e conforto). Em regiões de clima frio, o uso de materiais abrasivos em vez de sais de degelo para manter as rodovias livres de gelo, pode acelerar o desgaste. A erosão deve ser considerada principalmente em vertedouros, decantadores, canais e estruturas de pontes em contato com a água com partículas sólidas em suspensão.

A resistência ao desgaste superficial tem relação direta com a resistência à compressão do concreto e os agregados utilizados, em especial na camada superficial. 
Concretos mais resistentes, com agregados graúdos mais duros e em maior proporção, e com camada superficial adequadamente executada (sem exsudação, sem vibração excessiva e com cura adequada) serão menos suscetíveis a esta degradação. Os concretos que apresentam pouca exsudação têm camada superficial mais resistente e são, portanto, mais resistentes à abrasão (NEVILLE, 1982). Melhorias adicionais, ou recuperação de pisos desgastados ou deficiente, podem ser obtidas com a aplicação de tratamentos superficiais tais como os endurecedores superficiais, em geral a base de silicatos de sódio ou fluorsilicatos de magnésio e sódio, que promovem o fechamento dos poros superficiais por meio da reação com hidróxido de sódio disponível (MEHTA e MONTEIRO, 2008). Neville (1982) indica endurecedores de superfície metálicos, carboneto de silício, corundum ou ferrossilício.

Segundo Aïtcin (2000), a qualidade do agregado graúdo é o mais importante dos fatores que afetam a resistência do concreto à abrasão, com a relação água/aglomerante em segundo lugar. $\mathrm{O}$ uso de sílica ativa aumenta a resistência à abrasão, mas o efeito é menos importante que os dois anteriores. Com adequada relação água/aglomerante podese obter concretos tão resistentes à abrasão quanto à própria pedra de alta qualidade que origina o agregado graúdo.

A qualidade do agregado desempenha papel crítico, especialmente em concretos com maior resistência à compressão. A substituição parcial de areia natural por areia produzida a partir de rocha dura provoca diminuição da resistência à compressão, mas aumenta a resistência à abrasão. Agregados metálicos de altíssima dureza podem ser necessários em situações severas de desgaste (Aïtcin, 2000).

O uso de mais agregados por unidade superficial, graças a um melhor empacotamento, reduz a abrasão, principalmente se isto significa a maior incorporação de agregados graúdos de boa resistência. Já o excesso de areia pode ser prejudicial (NEVILLE, 1982). Bons agregados graúdos perdem a importância caso a sua exposição seja considerada excessiva. Neste caso a resistência da pasta de cimento ganha importância. Por outro lado, caso um polimento do piso seja especificado, o próprio polimento promove o desgaste da camada superficial menos resistente e expõe o agregado de maior qualidade ${ }^{46}$.

${ }^{46}$ Este é o princípio de pisos de alta resistência como, por exemplo, os comercialmente conhecidos Korodur e $P$ 600. 
Para mesma resistência de agregado, a abrasão depende da dureza da pasta. Quanto mais resistente e menos porosa, menores são os desgastes. No trabalho de Naik, Singh e Hossain (1995) se observa claramente esta relação direta entre desgaste e resistência (Figura 17).

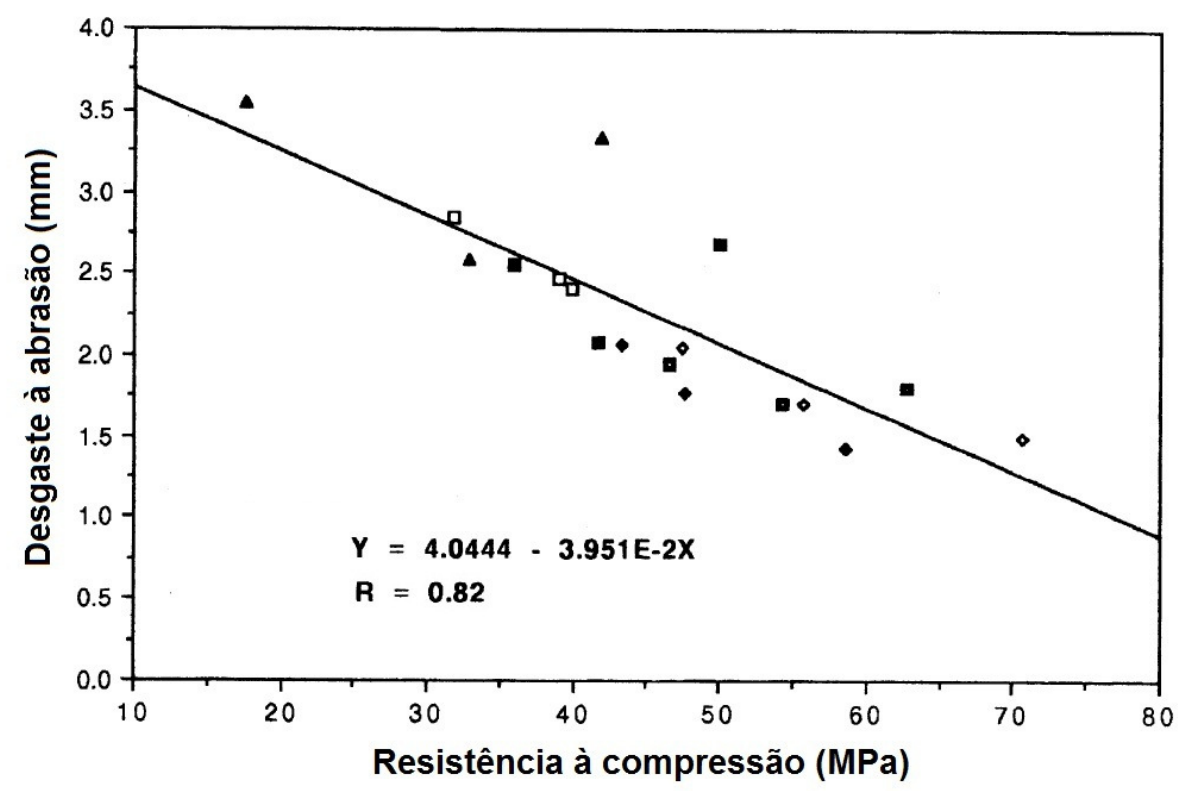

Figura 17 - Relação entre desgaste à abrasão e resistência do concreto. Fonte: adaptada Naik, Singh e Hossain (1995).

Adições minerais influenciam na proporção em que aumentam a resistência geral do concreto, diminuem a permeabilidade superficial e reduzem o risco de exsudação (NAIK, SINGH e HOSSAIN, 1995; MEHTA e MONTEIRO, 2008). Nas de baixa reatividade deve-se ter cuidado com melhor cura e solicitação mais tardia (ANDRADE, 2005).

A condição de umidade afeta a resistência momentânea do concreto. Perdas de 50 \% são relatadas em superfícies de blocos intertravados para pavimentação com concreto de $40 \mathrm{MPa}$ quando na situação úmida. Para resistências mais elevadas (80 MPa) não se registrou esta perda, o que se explica pela pequena penetração de água nestes concretos pouco porosos. A perda pode se explicar pela redução das forças de Van der Waals entre os produtos sólidos quando a pasta fica saturada (GHAFOORI e SUKANDAR ${ }^{47}$, 1995, apud ANDRADE, 2005).

${ }^{47}$ GHAFOORI, N.; SUKANDAR, B.M., Abrasion Resistance of Concrete Block Pavers. ACI Materials Journal, v. 92, n. 1, p. 25-36, jan.-fev. 1995. 
A qualidade obtida depende da execução. Para bom desempenho deve-se evitar a segregação e exsudação, empregando boa dosagem, com baixo abatimento, sem excesso de vibração, pois acumula pasta superficial, afastando os agregados mais densos da superfície. A aspersão de água, prática comum para facilitar o acabamento, assim como técnicas de acabamento superficial que promovem a subida desnecessária de pasta de cimento à superfície, devem ser evitadas. Cura adequada, preferencialmente úmida, evita a secagem prematura, causa de aumento da porosidade superficial por forçar a subida de água do interior do concreto para a superfície.

Ensaios que adequadamente avaliam a abrasão são difíceis de realizar, pois o efeito nas estruturas reais depende da causa exata. Não existem ensaios satisfatórios para avaliação de todas as condições. Os resultados, em geral, apenas apresentam resistência comparativa a um dado tipo de desgaste (NEVILLE, 1982). Aïtcin (2000) e Andrade (2005) concordam que é um ensaio complicado de realizar para ser representativo da realidade.

Há uma diversidade de ensaios, sendo diferentes entre si no grau de abrasividade e tipo de agressão real mais aplicada. Neville (1982) cita alguns ensaios, sendo na maioria descritos na ASTM C779 ${ }^{48}$, com exceção do jato de areia. Os mais utilizados compreendem o atrito com um disco metálico em movimento sobre o qual se despeja material abrasivo, o jateamento com areia, uso de coroas de desbaste ou impactos com esferas de aço.

No Brasil um único ensaio normatizado para avaliar o desgaste por abrasão de materiais inorgânicos é descrito pela ABNT NBR 12042:1992. Neste ensaio amostras de concreto são colocadas sobre um disco de ferro fundido em movimento, sendo despejado material granular abrasivo (areia normatizada) na interface de atrito. Sobre o corpo de prova é aplicada uma carga que proporciona tensão de contato de 13,5 kPa. Após um número de rotações equivalente a percurso de 500 e 1000 m são medidas as espessuras de concreto desgastadas. A ABNT NBR 11.801:1992 (Argamassa de alta resistência mecânica para pisos) especifica o desgaste para três níveis de solicitação (Tabela 8).

Analisando alguns casos de concreto e argamassas apresentadas na literatura técnica nacional e avaliadas conforme este ensaio de abrasão, nota-se a extrema severidade da classificação tipo A. Alguns trabalhos são citados a seguir.

${ }^{48}$ ASTM - AMERICAN SOCIETY FOR TESTING AND MATERIALS. C779: standard test method for abrasion resistance of horizontal concrete surfaces. West Conshohocken/Pennsylvania/USA, 1976. 
Tabela 8 - Classificação de níveis de solicitação de abrasão.

\begin{tabular}{ccc}
\hline $\begin{array}{c}\text { Nível de } \\
\text { solicitação }\end{array}$ & $\begin{array}{c}\text { Desgaste (D), em } \mathbf{~ m m}, \\
\text { para percurso de } \mathbf{1 0 0 0} \mathbf{m}\end{array}$ & Tipo de solicitação \\
\hline Grupo A & $\mathrm{D} \leq 0,8$ & $\begin{array}{c}\text { Arraste e rolar de cargas pesadas } \\
\text { Tráfego de veículos de rodas rígidas } \\
\text { Impacto de grande intensidade }\end{array}$ \\
\hline Grupo B & $0,8<\mathrm{D} \leq 1,6$ & $\begin{array}{c}\text { Arraste e rolar de cargas médias } \\
\text { Tráfego de veículos de rodas rígidas } \\
\text { Tráfego intenso de pedestre } \\
\text { Impacto de pequena intensidade }\end{array}$ \\
\hline Grupo C & $1,6<\mathrm{D} \leq 2,4$ & $\begin{array}{c}\text { Arraste e rolar de pequenas cargas leves } \\
\text { Tráfegos de veículos de rodas macias } \\
\text { Pequeno trânsito de pedestres }\end{array}$ \\
\hline
\end{tabular}

Fonte: ABNT NBR 11801:1992

Pereira (2010) elaborou concretos auto adensáveis, com baixo consumo de cimento e incorporação de fibras, obtendo valores de abrasão entre 1,4 e 1,7 mm.

Catoia (2007), que produziu ladrilhos hidráulicos com argamassa autoadensável de alto desempenho obteve desgastes elevados, na ordem de $4 \mathrm{~mm}$, alto principalmente devido à ausência de agregado graúdo. Reis e Tristão (2008), que avaliaram ladrilhos hidráulicos para piso tátil, obtiveram desgastes entre 5,7 e 7,8 mm em ladrilhos hidráulicos comerciais produzidos industrialmente. Convém mencionar que a ABNT NBR 9457:1986 que contém especificações para ladrilhos hidráulicos prescreve desgaste de $3 \mathrm{~mm}$ em percurso de 1000 $\mathrm{m}$.

Falcão Bauer, Takashima e Melo (2004) executaram concretos de alta resistência com diversos agregados e sílica ativa, atingindo resistências à compressão de 82 a 122 MPa aos 28 dias, com consumo de materiais cimentícios de $660 \mathrm{~kg} / \mathrm{m}^{3}$. Mesmo assim obtiveram desgastes acima de $2,0 \mathrm{~mm}$, o que seria classificado como classe $C$ apenas.

Uma aplicação de argamassa de alta resistência para pátio externo de uma indústria submetido a cargas estáticas, dinâmicas e concentradas, apresentada por Martins e Cañas Guillen (2004), obteve desgaste médio de 1,6 mm, classificação na transição do Grupo B para Grupo C.

Mesmo em traços especiais com uso de agregados metálicos (ferro silício) e agregados selecionados especiais a base de quartzo e diabásio não é fácil atender ao grupo A. Martins et al. (2006) desenvolveram programa experimental para piso de alta resistência mecânica a ser empregado na casa de força de uma UHE e que atendesse ao grupo A. Avaliaram várias dosagens e obtiveram resultados variando entre 0,57 mm e 1,35 mm, obtendo classificação A e B. 
$\mathrm{Na}$ avaliação de endurecedores de superfície, Viecili e Cremonini (2010) obtiveram resultados compatíveis com a classe $A$ apenas no caso de dosagem alta de endurecedor a base de agregados metálicos.

A norma europeia/britânica BSI BS EN 1097:2009 (Tests for mechanical and physical properties of aggregates), no Anexo A da parte 8 (Determination of the polished Stone value), descreve o método para obtenção do Aggregate Abrasion Value (AAV) para desgaste de agregados graúdos ${ }^{49}$ destinados a revestimento de rodovias. Utiliza um ensaio semelhante ao da ABNT NBR 12042:1992, porém com menor pressão de contato (apenas $30 \%$ e percurso ligeiramente inferior $(942 \mathrm{~m})$. Classifica a resistência ao desgaste conforme a perda de peso em corpos de prova de $25 \mathrm{~mm}$ de espessura. Em rodovias de concreto com agregado exposto, com tráfego acima de 3250 veículos comerciais por dia, admite-se perda máxima de $12 \%$. Se for rodovia de pouco movimento, com menos de 250 veículos comerciais por dia, um valor máximo de $16 \%$ é suficiente (TSO, 2006).

Silva (2000) avaliou abrasão de concretos nestas condições e obteve desgastes de $1,6 \%$ a 5,6 \%. Em traços equivalentes, aqueles com uso de sílica ativa apresentaram desgaste menor em cerca de $50 \%$.

\subsection{Ataque químico}

O ataque químico é um dos tipos de agressão mais graves a que concretos de cimento Portland podem estar sujeitos. Entre os tipos de ataques químicos, Neville (1982) cita a lixiviação do cimento, a ação de sulfatos, água do mar e águas ácidas.

$\mathrm{O}$ ataque de sulfatos ocorre quando há a penetração de sulfatos no concreto que reagem com o $\mathrm{Ca}(\mathrm{OH})_{2}$ e $\mathrm{C}_{3} \mathrm{~A}$ hidratado, formando produtos expansivos. Ataques de ácidos são extremamente deletérios, já que nenhum cimento Portland é resistente a ácidos, graças à sua natureza alcalina. Na prática, ocorre $\mathrm{o}$ ataque em valores de $\mathrm{pH}$ inferiores, aproximadamente, a 6,5, sendo mais severo quanto menor o $\mathrm{pH}$ (NEVILLE, 1982).

Na resistência a ataques químicos, o cimento tem papel fundamental (NEVILLE, 1982). Por exemplo, existem cimentos especialmente resistentes a sulfatos, com baixo teor de $\mathrm{C}_{3} \mathrm{~A}$ em sua composição. A inclusão de um ou até mais materiais cimentícios suplementares, como cinza volante, escória de alto forno, sílica ativa ou metacaulinita, pode aumentar a capacidade de fixação de elementos agressivos, além de promover densificação

\footnotetext{
${ }^{49}$ No Brasil atualmente a avaliação de desgaste de agregados é realizado pelo ensaio de abrasão "Los Angeles".
} 
da microestrutura, bloqueando e aumentando o caminho de ingresso dos agentes agressivos. Embora os cimentos de alto forno e o uso de pozolanas possam contribuir com melhor resistência química, o desempenho do concreto depende mais das suas qualidades próprias do que do tipo de cimento usado (NEVILLE, 1982). Uma menor permeabilidade propicia maior resistência química (AIITCIN, 2000). Em alguns casos, a maior densidade e menor permeabilidade do concreto modificam a tal ponto a durabilidade, que chegam a prevalecer sobre a influência de tipo de cimento (NEVILLE,1982).

Um maior teor de agregados é favorável à diminuição da velocidade do processo de degradação. Após o rápido desgaste da pasta superficial, a velocidade diminui à medida que os agregados ficam expostos, pois, além da superfície vulnerável ficar reduzida, o agente agressivo tem que contornar as partículas de agregado (NEVILLE, 1982). A carbonatação superficial do concreto é benéfica na resistência química, por reduzir a porosidade, alcalinidade e solubilidade superficial (NEVILLE, 1982).

A realização de ensaios para avaliar a resistência química a soluções ácidas é complicada, pois, a princípio, nenhum concreto à base de cimento Portland resiste a este ataque. Ensaios mais proveitosos devem reproduzir as condições reais às quais a estrutura será submetida. Ensaios acelerados podem por isso ser pouco conclusivos, mas podem ser utilizados para fins de análise comparativa (NEVILLE, 1982).

A imersão contínua, ou alternada com períodos de secagem, e a posterior determinação da perda de massa ou de resistência, são a base da maioria dos ensaios empregados para avaliar a resistência química, tanto a soluções ácidas como a sulfatos. $A$ concentração e tipo de substância agressiva dependem da finalidade do concreto. Ácidos inorgânicos (sulfúrico, clorídrico e nítrico), ácidos orgânicos (acético, lático e fórmico) e sulfatos (de sódio e de magnésio) são os mais utilizados (NEVILLE, 1982).

\subsection{Concretos e estruturas de alto desempenho}

As primeiras aplicações de concreto de alto desempenho (CAD) são da década de 60 e 70, em sua maioria em colunas de edifícios altos, portanto não submetidas a ambientes de agressividade severa. Aplicações em ambientes mais agressivos datam do fim da década de 80 e início da década de 90, não tendo, portanto, idade suficiente para que se possa fazer uma avaliação real de estruturas com CAD em ambiente severo. Baseado em experiências com concreto comum pode-se, no entanto, supor que estruturas com CAD são mais duráveis. Estas experiências mostraram que a durabilidade é governada basicamente pela permeabilidade do concreto e da agressividade do ambiente (AÏTCIN, 2003). 
É necessário, porém, evitar a fissuração desse concreto compacto e impermeável com cura adequada (AITCIN, 2000). Um exemplo de como a fissuração pode prejudicar a durabilidade foi explanada no início deste capítulo, no trabalho desenvolvido por Silva (2007). É, portanto, pertinente diferenciar concreto de alta durabilidade de estrutura de alta durabilidade. Uma estrutura de alta durabilidade pressupõe concepção estrutural de alto desempenho e execução de acordo com este princípio, ou seja, com material de alto desempenho (CAD) aplicado por equipe de produção de qualidade. Não somente o material concreto, mas todo o processo necessita ser aprimorado, desde a concepção estrutural, passando pelo controle de recebimento dos materiais até a execução propriamente dita. 


\section{MATERIAIS UTILIZADOS E METODOLOGIA EXPERIMENTAL}

Os experimentos realizados e descritos neste capítulo visam responder às questões que motivaram este trabalho, buscando-se atingir os objetivos estabelecidos referentes à avaliação de durabilidade de alguns concretos desenvolvidos com baixo consumo de cimento.

Inicialmente são descritos todos os materiais empregados nos diversos concretos ensaiados, com suas principais características. Algumas destas foram obtidas com os fabricantes e outras determinadas experimentalmente. Na sequência descrevem-se os ensaios preliminares executados. Estes ensaios visaram o estabelecimento dos traços a serem executados. A execução dos traços definitivos e os ensaios no estado fresco são descritos a seguir. Na parte final descrevem-se os ensaios mecânicos e de durabilidade empregados para avaliar os concretos executados.

\subsection{Materiais utilizados}

O passo inicial na elaboração de qualquer experimento no campo da análise de materiais consiste na avaliação das matérias-primas disponíveis. Esta avaliação deve considerar aspectos técnicos, tais como a qualidade, características físicas e químicas, aspectos econômicos, que envolvem os custos de aquisição, transporte, armazenamento e aplicação, e também aspectos relativos ao fornecimento, que se referem à garantia de fornecimento nas quantidades e prazos necessários e uniformidade dos produtos entregues. Assim, para os produtos consumidos em grandes quantidades, tais como os agregados, em geral dá-se preferência a fornecedores locais para reduzir os custos com transporte. A escolha do fornecedor de cimento, via de regra, limita-se a algumas poucas fábricas de cimento existentes no estado ou região. Já para materiais cujos consumos ocorrem em menores quantidades, tais como adições minerais e aditivos químicos, normalmente é possível optar por fornecedores a distâncias maiores, sendo que as características técnicas e custos de aquisição são mais determinantes que os custos com o transporte. Desta forma neste estudo optou-se por agregados encontrados na região de São Carlos/SP, cimento comercializado na região e adições minerais e aditivos químicos disponíveis a nível nacional. 


\subsubsection{Cimentos}

Foram utilizados dois tipos diferentes de cimento: CP V-ARI e CP III-40-RS, especificados respectivamente pelas ABNT NBR 5733:1991 e ABNT NBR 5735:1991. A razão desta escolha deve-se ao fato de serem cimentos com características muito distintas em termos de percentual de clínquer presente. O cimento CP V-ARI constitui-se de no mínimo 95 \% de clínquer. Já o CP III-40-RS possui grande parte do clínquer substituído por escória de alto forno (35 a $70 \%$ ). Na Tabela 9 apresentam-se as principais características físicas, químicas e mecânicas destes dois cimentos.

Tabela 9 - Características físicas, químicas e mecânicas dos cimentos utilizados.

\begin{tabular}{|c|c|c|c|}
\hline Característica & Unidade & CP V-ARI & CP III-40-RS \\
\hline $\begin{array}{c}\text { Finura Peneira } 200 \\
\text { (abertura } 75 \mu \mathrm{m})\end{array}$ & $\%$ retida & 0,07 & 0,20 \\
\hline $\begin{array}{c}\text { Finura Peneira } 325 \\
\text { (abertura } 45 \mu \mathrm{m})\end{array}$ & $\%$ retida & 0,19 & 1,50 \\
\hline $\begin{array}{l}\text { Superfície específica } \\
\text { Blaine }\end{array}$ & $\mathrm{cm}^{2} / \mathrm{g}$ & 4.743 & 4.371 \\
\hline Densidade aparente & $\mathrm{g} / \mathrm{cm}^{3}$ & 0,95 & 0,99 \\
\hline Densidade absoluta & $\mathrm{g} / \mathrm{cm}^{3}$ & 3,12 & 2,96 \\
\hline $\begin{array}{c}\text { Água de consistência } \\
\text { de pasta }\end{array}$ & $\%$ & 32,0 & 31,6 \\
\hline Início de pega & $\mathrm{h}: \min$ & $1: 50$ & $2: 55$ \\
\hline Fim de pega & $\mathrm{h}: \min$ & $2: 43$ & $3: 30$ \\
\hline Resistência 3 dias & $\mathrm{MPa}$ & 44,4 & 24,4 \\
\hline Resistência 7 dias & $\mathrm{MPa}$ & 47,9 & 28,8 \\
\hline Resistência 28 dias & $\mathrm{MPa}$ & 52,2 & 36,8 \\
\hline Perda ao fogo & $\%$ & 4,06 & 3,5 \\
\hline Insolúveis & $\%$ & 0,84 & 1,66 \\
\hline Teor de escória & $\%$ & - & 46,14 \\
\hline $\mathrm{SiO}_{2}$ & $\%$ & 19,20 & 25,64 \\
\hline $\mathrm{Fe}_{2} \mathrm{O}_{3}$ & $\%$ & 3,03 & 2,18 \\
\hline $\mathrm{Al}_{2} \mathrm{O}_{3}$ & $\%$ & 5,97 & 10,24 \\
\hline $\mathrm{CaO}$ & $\%$ & 63,47 & 51,69 \\
\hline $\mathrm{MgO}$ & $\%$ & 0,59 & 3,32 \\
\hline $\mathrm{SO}_{3}$ & $\%$ & 2,76 & 1,82 \\
\hline $\mathrm{Na}_{2} \mathrm{O}$ & $\%$ & 0,17 & 0,22 \\
\hline $\mathrm{K}_{2} \mathrm{O}$ & $\%$ & 0,83 & 0,63 \\
\hline Equivalente alcalino & $\%$ & 0,71 & 0,63 \\
\hline Cal livre em $\mathrm{CaO}$ & $\%$ & 2,19 & 1,04 \\
\hline
\end{tabular}

Fonte: relatórios C.060-2011 (CP V-ARI) e 23280 (CP III-40-RS) do LCEC/CESP. 


\subsubsection{Adições minerais}

Foram utilizadas duas adições minerais: sílica ativa e metacaulinita. Estas foram escolhidas com o intuito de promover o refinamento de poros por meio da ação pozolânica e de empacotamento nos níveis abaixo da granulometria do cimento. Optou-se em utilizar as duas simultaneamente, pois apresentam finura diferenciada permitindo empacotamento também entre si. A massa específica foi determinada conforme a ABNT NBR NM 23:2000. As demais características citadas foram fornecidas pelos fabricantes.

A sílica ativa (Elkem Microsilica® 920D), proveniente da fabricação de ligas de ferrosilício, possui massa específica de $2,23 \mathrm{~g} / \mathrm{cm}^{3}$. A fabricante, Elkem Materials South America Ltda., indica ainda área superficial específica (BET) mínima de $150.000 \mathrm{~cm}^{2} / \mathrm{g}$ da sílica dispersa, teor de sílica amorfa de 85 a $99 \%$, carbono de 1 a $6 \%$ e o restante composto de óxidos de ferro, alumínio e magnésio. O produto é densificado para transporte, tendo retenção na peneira 325 (abertura $45 \mu \mathrm{m}$ ) inferior a 10 \% (ELKEM, 2008).

A metacaulinita, na variedade vermelha, possui massa específica de $2,57 \mathrm{~g} / \mathrm{cm}^{3}$. A fabricante, Metacaulim do Brasil Ltda., indica ainda área superficial específica (BET) mínima de $300.000 \mathrm{~cm}^{2} / \mathrm{g}$, com teor de $\mathrm{SiO}_{2}$ de $51 \%, \mathrm{Al}_{2} \mathrm{O}_{3}$ de $41 \%$ e retenção na peneira 325 (abertura $45 \mu \mathrm{m}$ ) inferior a $1 \%$ (METACAULIM DO BRASIL, 2011).

\subsubsection{Fíler}

Utilizou-se um fíler, a base de quartzo moído, utilizado como matéria prima na produção de tintas, plásticos, borrachas, fritas cerâmicas, esmaltes, monofilamentos de fibra de reforço e abrasivos. Este material, produzido pela Mineração Jundu Ltda., é fornecido em várias granulometrias controladas, sendo utilizado neste trabalho o SM500, que possui grãos passantes na peneira 500 (abertura $25 \mu \mathrm{m}$ ) A massa específica é de $2,64 \mathrm{~g} / \mathrm{cm}^{3}$, determinado conforme a ABNT NBR NM 23:2000.

Pereira (2010), que utilizou o mesmo material, realizou determinação da granulometria do SM500 por sedimentação. Na Figura 18 indica-se a granulometria determinada. Nota-se a finura do material, na faixa de 2 a $20 \mu \mathrm{m}$, normalmente encontrada em cimentos. Este material tem, portanto, potencial para atuar na substituição de cimento, como sugerido em ensaios por Bentz (2005). 
PENEIRAS ABNT ( NBR 5734/80)

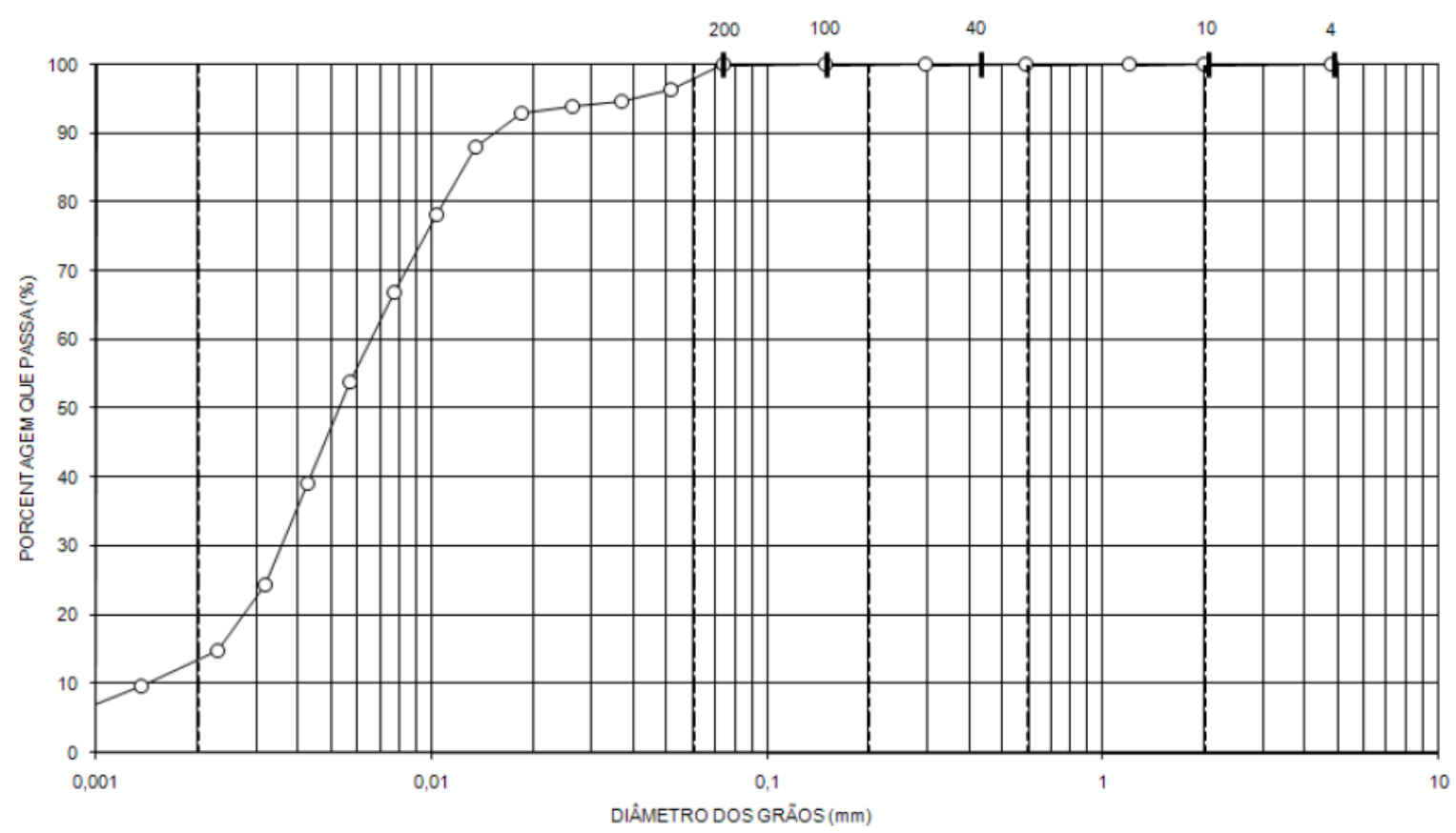

Figura 18 - Curva granulométrica do fíler SM500, obtida em ensaio de sedimentação.

Fonte: Pereira (2010).

\subsubsection{Agregados miúdos}

A caracterização dos agregados miúdos seguiu as recomendações das normas brasileiras vigentes: composição granulométrica, dimensão máxima característica e módulo de finura (ABNT NBR NM 248:2003); classificação granulométrica (ABNT NBR 7211:2009); massa unitária no estado solto e estado compactado seco e índice de vazios (ABNT NBR NM 45:2006); massa específica (ABNT NBR NM 52:2009).

As areias empregadas são todas do tipo quartzosas, originárias de cava, da região de São Carlos/SP. Foi realizada visita a empresas fornecedoras e dentre a diversidade de areias disponíveis, três areias foram selecionadas, após análise visual e granulométrica prévia. Os resultados de caracterização destas areias estão resumidos na Tabela 10. 
Tabela 10 - Caracterização física dos agregados miúdos

\begin{tabular}{|c|c|c|c|c|}
\hline \multirow{2}{*}{\multicolumn{2}{|c|}{ Propriedades }} & \multicolumn{3}{|c|}{ Materiais } \\
\hline & & \multirow[t]{2}{*}{ Areia 1} & \multirow[t]{2}{*}{ Areia 2} & \multirow[t]{2}{*}{ Areia 3} \\
\hline \multirow{7}{*}{ 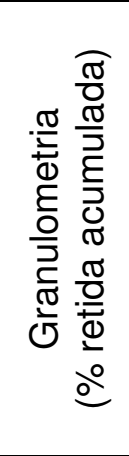 } & $\begin{array}{l}\text { ura peneiras } \\
(\mathrm{mm})\end{array}$ & & & \\
\hline & 4,75 & 0,0 & 0,0 & 0,0 \\
\hline & 2,36 & 13,3 & 0,0 & 0,0 \\
\hline & 1,18 & 50,5 & 0,0 & 0,1 \\
\hline & 0,6 & 95,7 & 0,6 & 0,2 \\
\hline & 0,3 & 99,8 & 42,7 & 3,3 \\
\hline & 0,15 & 100,0 & 84,5 & 41,9 \\
\hline \multicolumn{2}{|c|}{$\begin{array}{l}\text { Diâmetro máximo característico } \\
(\mathrm{mm})\end{array}$} & 4,75 & 0,6 & 0,3 \\
\hline \multicolumn{2}{|c|}{ Módulo de finura } & 3,59 & 1,28 & 0,45 \\
\hline \multicolumn{2}{|c|}{ Classificação } & Grossa & Muito Fina* & Muito Fina** \\
\hline \multicolumn{2}{|c|}{$\begin{array}{l}\text { Massa específica seca } \\
\left(\mathrm{g} / \mathrm{cm}^{3}\right)\end{array}$} & 2,620 & 2,646 & 2,637 \\
\hline \multicolumn{2}{|c|}{$\begin{array}{l}\text { Massa unitária solta } \\
\left(\mathrm{g} / \mathrm{cm}^{3}\right)\end{array}$} & 1,528 & 1,593 & 1,434 \\
\hline \multicolumn{2}{|c|}{$\begin{array}{l}\text { Massa unitária compactada seca } \\
\left(\mathrm{g} / \mathrm{cm}^{3}\right)\end{array}$} & 1,611 & 1,731 & 1,606 \\
\hline \multicolumn{2}{|c|}{$\begin{array}{c}\text { Índice de vazios } \\
(\%)\end{array}$} & 38,5 & 34,6 & 39,1 \\
\hline
\end{tabular}

* esta areia possui granulometria próximo ao limite inferior para a classificação de "Muito Fina" conforme as classes da ABNT NBR 7211:2009.

** esta areia possui granulometria abaixo da menor classificação disponível na ABNT NBR 7211:2009.

\subsubsection{Agregados graúdos}

A caracterização dos agregados graúdos seguiu as recomendações das normas brasileiras vigentes: composição granulométrica, dimensão máxima característica e módulo de finura (ABNT NBR NM 248:2003); classificação granulométrica (ABNT NBR 7211:2009); massa unitária no estado solto e estado compactado seco e índice de vazios (ABNT NBR NM 45:2006); massa específica (ABNT NBR NM 53:2009).

Os agregados graúdos empregados são de origem basáltica, na forma britada, originários da região de Ribeirão Preto/SP. Foi realizada visita a empresas fornecedoras, selecionando-se uma brita 1 e um pedrisco após inspeção visual e análise granulométrica prévia. Os resultados de caracterização destes dois materiais estão resumidos na Tabela 11. 
Tabela 11 - Caracterização física dos agregados graúdos

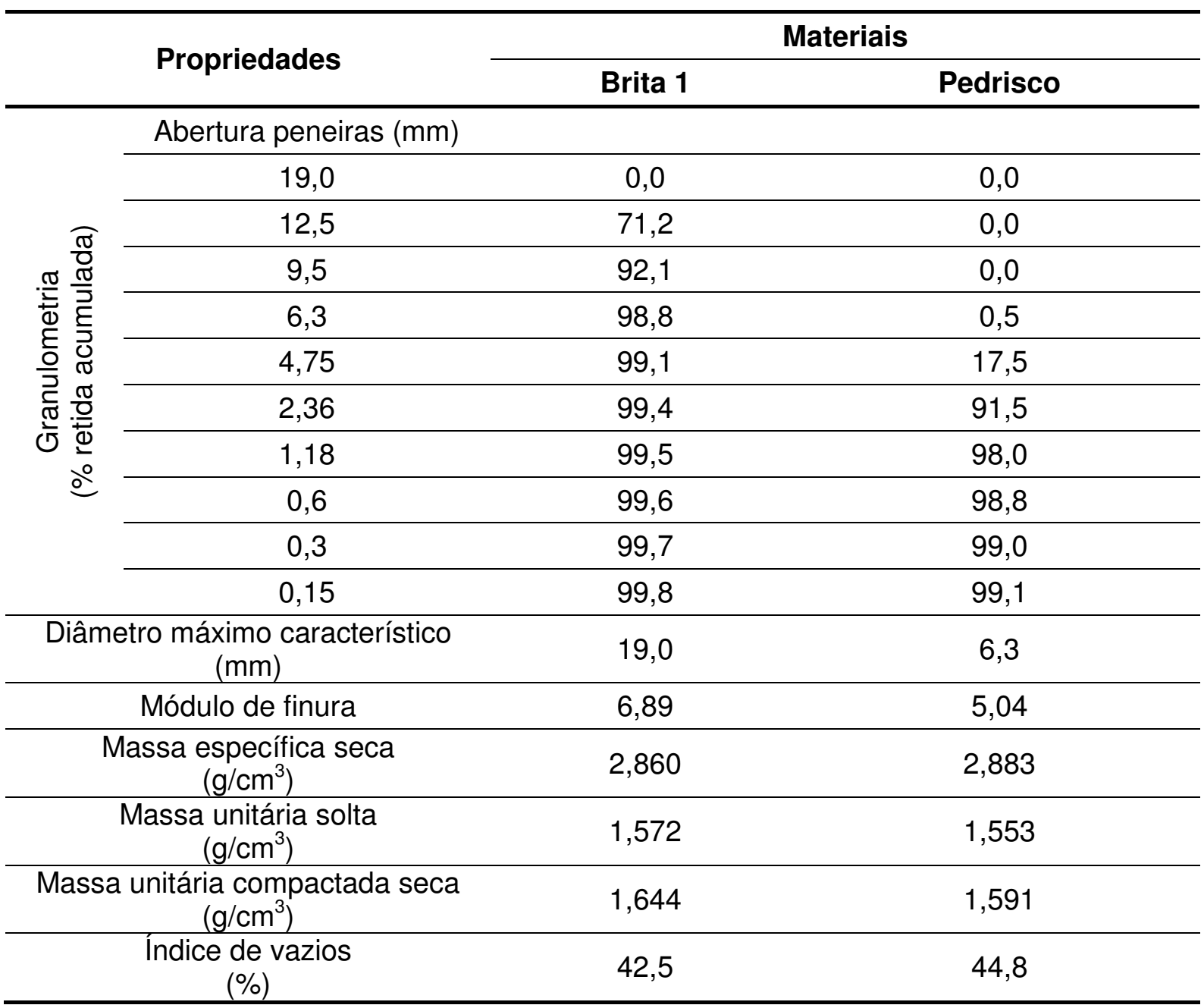

\subsubsection{Aditivos superplastificantes}

Vários superplastificantes (SP) à base de policarboxilatos foram testados. Optou-se por este tipo de aditivo devido ao grande poder de redução de água que estes possuem. Isto é fundamental para a produção de bons concretos com baixos consumos de cimento.

Após avaliação de desempenho e compatibilidade aditivo-cimento, optou-se por utilizar um único aditivo para todos os concretos de baixo consumo de cimento. $O$ aditivo Glenium ${ }^{\circledR} 160$ SCC, produto desenvolvido pela BASF para produção de concretos autoadensáveis e concretos de alto desempenho, é baseado em uma cadeia de éter policarboxílico modificado, proporcionando alta redução de água, permitindo manutenção de trabalhabilidade mesmo para baixos consumos de cimento. Segundo informação do fabricante (BASF, 2011), os polímeros de éter policarboxílico possuem largas cadeias laterais, que se depositam na superfície das partículas de cimento iniciando o mecanismo de dispersão eletrostática, porém as cadeias laterais são unidas a estruturas poliméricas 
gerando uma energia que estabiliza a capacidade de refração e dispersão das partículas de cimento. Com esse mecanismo, mesmo durante o inicio do processo de hidratação do cimento, o polímero continua atuando promovendo a dispersão das partículas.

O Glenium ${ }^{\circledR} 160$ SCC apresenta-se na cor castanha clara, tem densidade média de $1,11 \mathrm{~g} / \mathrm{cm}^{3}$ e teor de sólidos médio de $40 \%$, segundo informações do fabricante (BASF, 2011).

\subsection{Ensaios preliminares}

Para a elaboração de concretos de baixo consumo de cimento buscou-se a otimização dos fatores que influenciam na resistência do concreto, conforme detalhado na seção 2.5 (Produção de concreto de alta resistência com baixo consumo de cimento). $\mathrm{Na}$ sequência detalham-se os procedimentos adotados para obter um máximo preenchimento do volume de concreto com sólidos, avaliação da compatibilidade de aditivos e cimentos e determinação do teor de aditivo. Alguns concretos auxiliares foram executados para verificar a trabalhabilidade obtida e a influência de alguns parâmetros.

\subsubsection{Empacotamento dos agregados}

Optou-se pelo processo experimental de empacotamento dos agregados através de misturas sucessivas, por ser um método que pode ser empregado em qualquer local e por considerar a interação entre as partículas reais, inclusive os seus formatos e texturas superficiais. Este método é executado em etapas sucessivas. Cada etapa otimiza a mistura entre dois materiais ou misturas já estabelecidas. Descreve-se a seguir uma destas etapas, denominando genericamente os dois materiais de Material A e Material B.

Toma-se uma quantidade do Material A suficiente para preencher no estado compactado o recipiente utilizado na determinação da massa unitária compactada. Utilizouse neste trabalho recipiente de aproximadamente $15 \mathrm{~L}$ para o estudo dos agregados graúdos e de $3 \mathrm{~L}$ para os agregados miúdos. Inicialmente realiza-se o preenchimento do recipiente com o Material $A$, em três camadas, recebendo cada camada compactação com 25 golpes de uma barra de aço $16 \mathrm{~mm}$. Ao final da terceira camada, e após o nivelamento da superfície superior, o recipiente é pesado. A razão entre a massa de material compactado e o volume do recipiente é a massa unitária compactada. Devido à variabilidade no processo de compactação utilizou-se neste trabalho sempre médias de três medidas. 
O passo seguinte é repetir este procedimento com misturas dos Materiais $A$ e $B$ em diversas proporções. Por razões de economia de materiais isto pode ser realizado reaproveitando o material $A$ já utilizado, acrescentando a quantidade necessária de material B para obter a proporção desejada. A quantidade a ser acrescentada pode ser calculada em cada etapa pela fórmula:

$$
\Delta m_{B}^{i}=\frac{m_{A}}{\%_{A}^{i}}-m_{A}-m_{B}^{i-1}
$$

sendo $\Delta m_{B}^{i}$ a massa de material $\mathrm{B}$ a ser acrescentado na etapa i, $m_{A}$ é a massa de material A (constante durante o ensaio), $m_{B}^{i-1}$ é o total de material B presente na etapa anterior e $\%_{A}^{i}$ é a porcentagem de Material A na etapa i.

Pode-se notar que, à medida que a porcentagem de material $A$ vai decrescendo, são necessários acréscimos cada vez maiores de material B. No caso em que se deseja analisar todo o espectro de misturas (0 a $100 \%$ ) costuma-se realizá-lo em duas partes, partindo de $100 \%$ de material $A$ até $50 \%$, acrescentando material $B$, e depois partindo de $100 \%$ de material $B$ e acrescentando material $A$ até $50 \%$. Com isto pode-se obter a curva completa de empacotamento sem necessitar de gastos muito grandes de material. Curvas completas (0 a $100 \%$ ) normalmente são feitas em intervalos de $10 \%$, podendo-se refinar os intervalos à medida que se aproxima do pico de máximo empacotamento. Para cada mistura realizada obtém-se a massa unitária compactada. Na Figura 19 apresenta-se o resultado do ensaio obtido com os agregados graúdos deste trabalho.

O resultado de massa unitária compactada (M.U.C.) já fornece boa ideia do melhor preenchimento dos vazios com material sólido. No entanto, a melhor forma de expressar isto é por meio do índice de vazios. Principalmente quando a densidade dos dois materiais é diferente, pode ocorrer que o ponto de máxima massa unitária compactada seja diferente do ponto de menor índice de vazios. Devido a isto, se optou neste trabalho por utilizar o índice de vazios na determinação do ponto ótimo de mistura. Conhecendo as massas específicas de cada material pode-se calcular o volume real ocupado pelos sólidos em cada mistura. $O$ índice de vazios (I.V.) é a porcentagem de volume de vazios em relação ao volume total. Matematicamente isto pode ser expresso por:

$$
\text { I.V. }=100 \%-\left(\frac{\%_{A}}{\gamma_{A}}+\frac{\%_{B}}{\gamma_{B}}\right) \cdot(\text { M.U.C. })
$$

sendo $\%_{A}$ e $\%_{B}$ as porcentagens dos materiais A e B, $\gamma_{A}$ e $\gamma_{A}$ as massas específicas e M.U.C. a massa unitária compactada da mistura. 


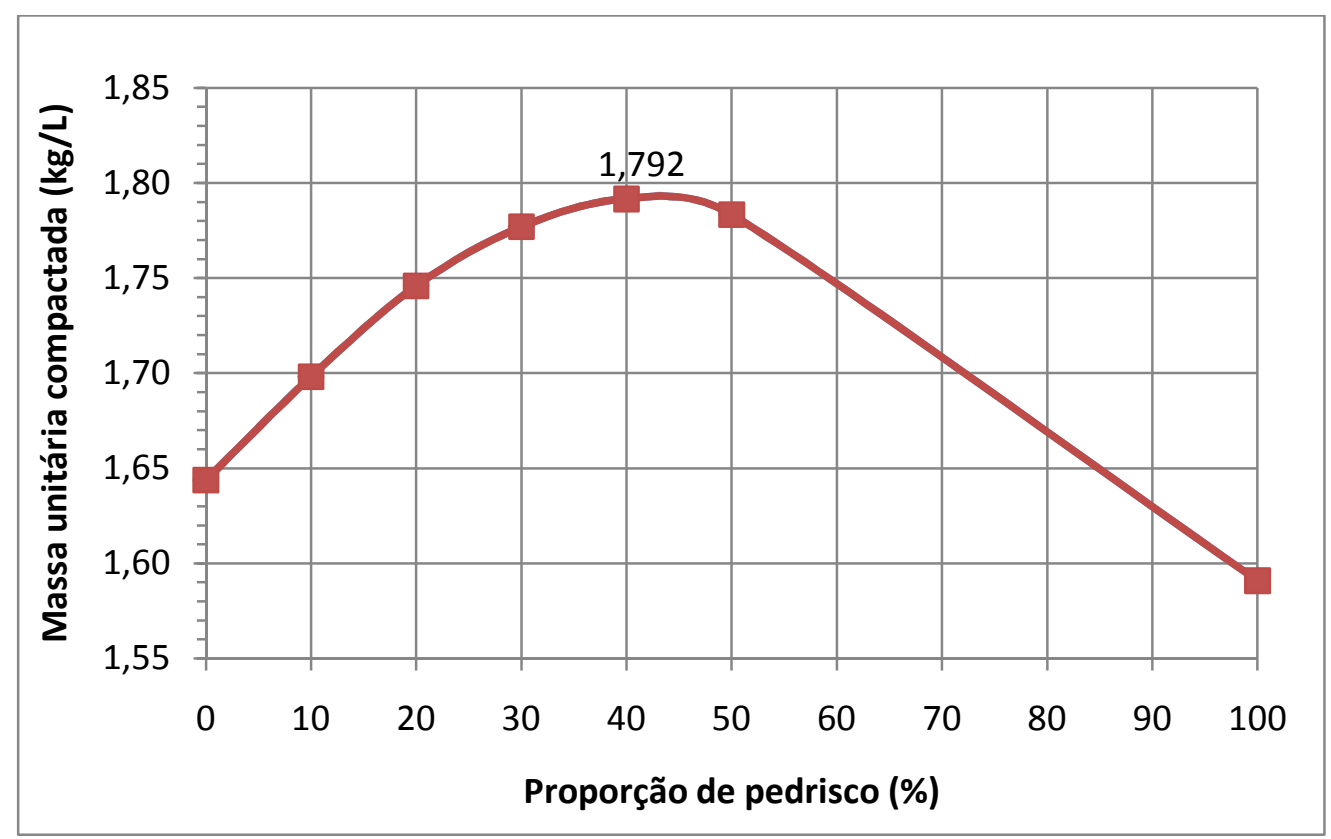

Figura 19 - Empacotamento de agregados graúdos, representado em termos de massa unitária compactada.

O resultado da mistura de brita 1 e pedrisco em termos de índice de vazios é mostrado na Figura 20. A conclusão do ensaio é que a melhor proporção entre brita $1 \mathrm{e}$ pedrisco corresponde a $60 \%$ de brita 1 e $40 \%$ de pedrisco. Nesta condição restam ainda $37,6 \%$ de vazios, volume este a ser preenchido com agregados miúdos e pasta de cimento.

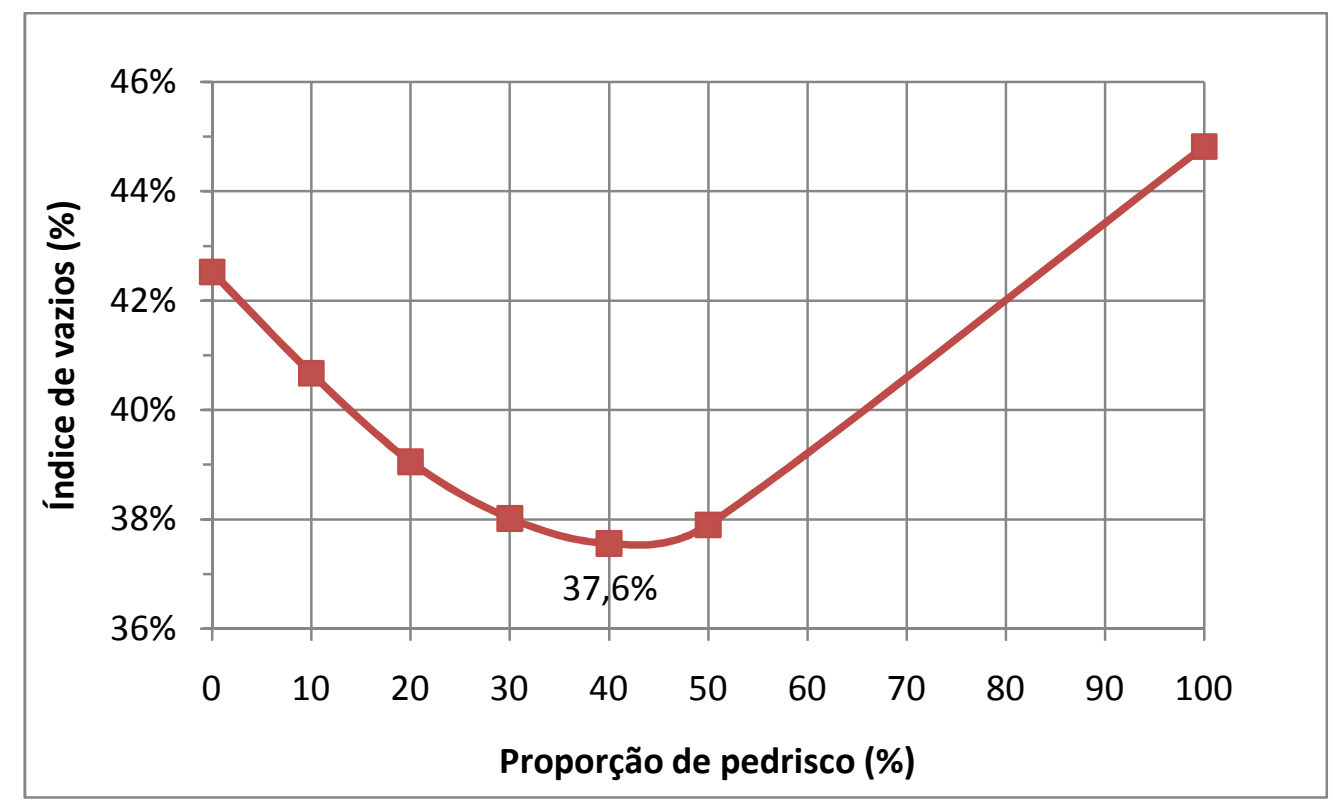

Figura 20 - Empacotamento de agregados graúdos, representado em termos de índice de vazios. 
O procedimento de misturas sucessivas continua após o estabelecimento do ponto ótimo de mistura entre os dois primeiros materiais. Esta mistura ótima passa a ser o Material A de uma nova etapa com um terceiro material, o qual será o novo Material B. Repetem-se todos os passos descritos acima para obtenção da melhor mistura, a qual representará uma mistura otimizada entre os três materiais presentes. Este processo pode ser repetido quantas vezes forem necessárias, sendo realizado normalmente na ordem decrescente de granulometria, de forma que os vazios restantes sejam cada vez mais preenchidos por grãos menores.

Neste trabalho optou-se por realizar o processo de empacotamento em duas fases. $\mathrm{Na}$ primeira empacotaram-se separadamente os agregados graúdos e os agregados miúdos. Nota-se que foi incluído na fase de empacotamento de agregado miúdo o fíler SM500. Por fim numa segunda fase realizou-se o empacotamento entre a melhor mistura de agregados graúdos e a melhor mistura de agregados miúdos.

\subsubsection{Avaliação dos aditivos}

Para fins de avaliação de compatibilidade cimento-aditivo e determinação do teor ótimo de aditivo foram realizados ensaios de miniabatimento de tronco de cone, também chamado de Ensaio de Kantro.

Inicialmente devem-se pesar os materiais a serem utilizados. Para um ensaio, $500 \mathrm{~g}$ de cimento são suficientes. Adota-se relação água/cimento igual para todos os ensaios. Neste trabalho optou-se por fator $\mathrm{a} / \mathrm{c}=0,35$, por permitir espalhamento em intervalos aceitáveis para os diversos consumos de aditivo. O uso de maior quantidade de água pode levar à exsudação da pasta e a contornos de espalhamento mais irregulares. Teores muito baixos de água prejudicam avaliar o espalhamento a baixos teores de aditivo. Com base na relação a/c adotada pode-se calcular a água necessária. A quantidade de aditivo é calculada como porcentagem da massa seca de cimento e é o parâmetro a ser variado nos diversos ensaios sequenciais. Antes do uso os aditivos devem ser vigorosamente agitados para evitar heterogeneidade de concentração.

Os materiais são misturados em misturador de laboratório, tendo-se adotado sequência de mistura onde inicialmente coloca-se o cimento e $90 \%$ da água na cuba da argamassadeira, misturando em velocidade baixa por 60 segundos. A seguir, durante 30 segundos, raspa-se o material aderido na cuba e no misturador com auxílio de espátula de aço pequena, misturando em seguida em velocidade baixa por mais 30 segundos. $O$ aditivo e os $10 \%$ restantes da água são então acrescentados, limpando o vasilhame do aditivo com 
a água para garantir que todo o aditivo tenha sido adicionado à pasta. $\mathrm{O}$ tempo considerado como início da ação do aditivo é o tempo em que o primeiro aditivo entra em contato com a pasta. Este é o tempo zero que foi considerado nas análises. Segue mais uma etapa de mistura em velocidade baixa durante 80 segundos, após a qual, com auxílio de espátula de aço pequena mistura-se manualmente a pasta para desgrudar eventual massa mais consistente presa ao fundo e laterais da cuba durante 60 segundos. A mistura final se processa em velocidade alta por 90 segundos.

O ensaio de espalhamento consiste em despejar a pasta dentro do tronco de cone até o nível superior. Previamente, com auxílio de um pincel, deve ser aplicada fina camada de óleo mineral na superfície de vidro sobre o qual é realizado o ensaio e nas faces internas do cone. Levanta-se então o tronco de cone na vertical e deixa-se escorrer o material. As medidas dos diâmetros de espalhamento são realizadas 60 segundos após o levantamento do molde. Realizam-se quatro medidas de diâmetro na pasta espalhada, em intervalos de $45^{\circ}$, com ajuda de um paquímetro.

Depois de realizadas as medidas, a pasta é recolhida à cuba, retornando à argamassadeira, onde permanece tampada com pano úmido para evitar a perda de água e submetida a mistura na velocidade lenta até a próxima medida.

Cerca de 3 minutos antes da próxima medida deve-se verificar com auxílio de espátula de aço pequena se existe material consistente preso ao fundo e laterais da cuba. Caso houver raspar e misturar manualmente durante 60 segundos. Antes do novo ensaio deixa-se misturar a pasta em velocidade alta por 90 segundos.

Os ensaios são realizados em intervalos constantes, dentro do tempo previsto para aplicação do concreto. Como neste trabalho não havia nenhuma aplicação real a ser atendida considerou-se que um tempo de aplicação de 1 hora pode ser considerado adequado para boa parcela dos concretos executados em obra. Realizou-se neste intervalo leituras a cada 15 minutos e leitura inicial com 5 minutos, perfazendo um total de 5 leituras.

Como pode haver alterações nos resultados, em função das condições ambientais, adotaram-se limites de temperatura de $22+/-2^{\circ} \mathrm{C}$ e umidade relativa de $65+/-5 \%$.

Na Figura 21 mostram-se algumas fotografias da execução do ensaio. 

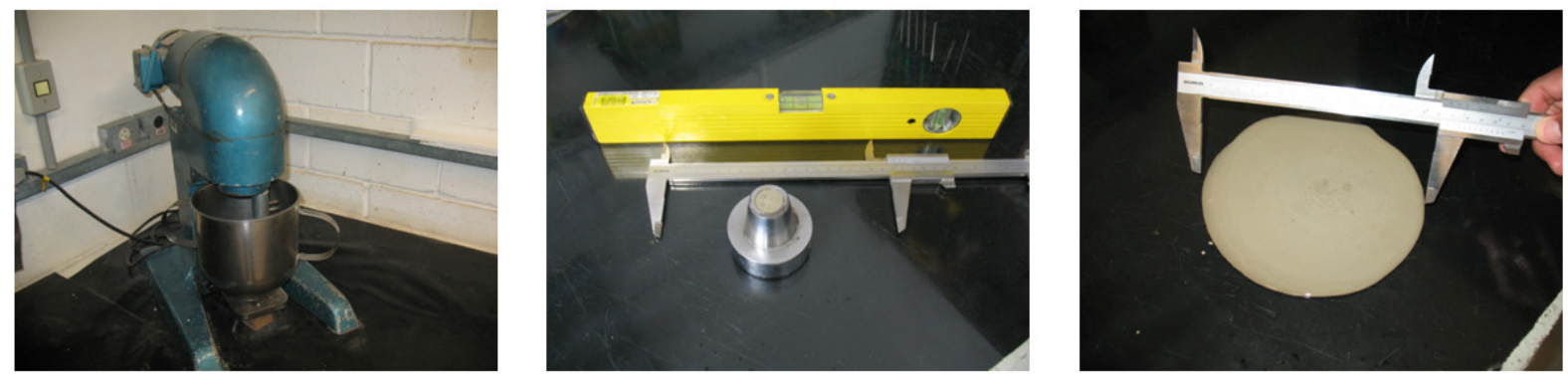

Figura 21 - Ensaio de miniabatimento de tronco de cone. Mistura em argamassadeira de laboratório (esquerda); minitronco de cone preenchido e paquímetro sobre superfície de vidro nivelada (centro); medida do diâmetro da pasta espalhada (direita).

\subsubsection{Concretos auxiliares}

Estabelecidos os parâmetros iniciais de composição dos agregados e porcentagem de aditivo, avaliaram-se alguns traços iniciais como teste para avaliar o potencial de redução do consumo de cimento. Estes traços foram executados em pequeno volume em misturadora de mesa (argamassadeira com misturador adaptado para concreto). O volume é suficiente apenas para realizar um ensaio de consistência pelo abatimento do tronco de cone - "slump test" - (NBR NM 67:1998) e posteriormente moldagem de quatro corpos de prova cilíndricos $10 \mathrm{~cm}$ x $20 \mathrm{~cm}$. Optou-se por romper estes corpos de prova à compressão nas idades de 7 e 28 dias, sendo dois para cada idade. Devido à pequena quantidade de amostras, este ensaio teve finalidade apenas exploratória para indicar a viabilidade da confecção dos concretos planejados e avaliar a influência de alguns parâmetros.

Dentre as opções estudas nesta fase estão o procedimento de mistura, o consumo de cimento, a quantidade de água necessária, alternativas de empacotamento, tipos de aditivos, teores de aditivos e eliminação de alguns dos materiais.

\subsection{Dosagem}

Escolheu-se trabalhar com dois tipos de cimento com propriedades distintas, sendo um sem adições (cimento CP V-ARI) e outro com um máximo de adições (cimento CP III-40$\mathrm{RS}$ ). Para cada tipo de cimento foram confeccionados dois concretos com baixo consumo de cimento e um concreto de referência. $O$ concreto de referência se justifica pelo caráter comparativo de vários ensaios de durabilidade. Têm-se assim para cada cimento um total de três traços totalizando seis dosagens de concreto a serem avaliadas. 


\subsubsection{Concretos com baixo consumo de cimento}

Para atingir o objetivo deste trabalho foram propostos concretos com baixo consumo de cimento para os dois tipos de cimento. Considera-se aqui como de baixo consumo aqueles concretos que possuem baixa relação consumo/resistência. Foram avaliados dois concretos, sendo que um com consumo dentro dos limites normativos atuais e um segundo abaixo destes limites.

Para o primeiro concreto de baixo consumo de cimento adotou-se consumo de $280 \mathrm{~kg} / \mathrm{m}^{3}$, equivalente ao mínimo exigido pela ABNT NBR 12655:2006 para classe de agressividade II. Um motivo adicional para esta escolha é o fato dos ensaios preliminares terem mostrado que traços com estes consumos possuem relação água/aglomerantes próxima da relação água/cimento dos traços de referência.

Para o segundo concreto de baixo consumo reduziu-se o consumo de cimento próximo do mínimo, de modo que o volume de pasta de cimento seja suficiente para ainda preencher os vazios do esqueleto de agregados. Isto resulta em consumos em torno de 200 $\mathrm{kg} / \mathrm{m}^{3}$, abaixo portanto das exigências normativas mínimas.

\subsubsection{Concretos de referência}

Os concretos de referência seguem as recomendações da ABNT NBR 12655:2006 para a máxima exigência de durabilidade (classe de agressividade IV). Esta norma estipula três critérios que devem ser atendidos simultaneamente: resistência à compressão acima de um limite mínimo, relação água/cimento abaixo de um limite máximo e consumo de cimento acima de um limite mínimo. Estes parâmetros são fixados para as diferentes classes de agressividade ambiental, independente do tipo de cimento, uso de adições minerais e de aditivos, ou qualquer outra restrição. Sendo assim, os concretos de referência foram elaborados utilizando-se agregados comumente utilizados na construção civil (um agregado graúdo e um agregado miúdo), os mesmos cimentos utilizados nos concretos de baixo consumo de cimento, e sem o uso de aditivos ou adições minerais.

Após a avaliação de alguns traços testes (ver anexo A.3) observou-se que para os dois tipos de cimento utilizados os parâmetros limitantes são:

- Cimento CP V-ARI: fator água/cimento $=0,45$. Com isto foi necessário consumo de cimento de $420 \mathrm{~kg} / \mathrm{m}^{3}$, para que se obtivesse trabalhabilidade adequada com lançamento convencional. A resistência ficou acima de $40 \mathrm{MPa}$; 
- Cimento CP III-40-RS: resistência = $40 \mathrm{MPa}$. Para isto houve necessidade de utilizar relação água/cimento $=0,43$ e consumo de cimento de $440 \mathrm{~kg} / \mathrm{m}^{3}$.

\subsubsection{Concreto fresco}

A mistura foi realizada em betoneira de laboratório com capacidade para $220 \mathrm{~L}$, seguindo ordens de mistura distintas para os concretos de baixo consumo e os de referência.

Os concretos de referência foram misturados conforme procedimentos normalmente utilizados na tecnologia de concretos convencional (HELENE, 1992), na seguinte sequência: $80 \%$ da água, agregado graúdo, agregado miúdo, cimento e $20 \%$ restante da água. A mistura ocorreu em sequência, em intervalos de cerca de 3 minutos entre cada material, suficiente para promover a homogeneização dos materiais presentes na betoneira.

Nos concretos com baixo consumo de cimento, mesmo tendo altas taxas de aditivo em relação ao cimento, o consumo volumétrico em relação ao traço todo não é muito alto. Também o consumo de água precisa ser mantido baixo. A demanda de água e aditivo é decorrente principalmente dos materiais mais finos (aglomerantes e fílers). Nos ensaios prévios observou-se que realizando a mistura em uma sequência que direcionasse a água e o aditivo para estes materiais, resultava em melhor trabalhabilidade. Adotou-se por isto sequencia de mistura diferenciada para os concretos de baixo consumo de cimento, sendo preparada primeiro a mistura de cimento, adições minerais, água e aditivo superplastificante, em seguida adicionados os agregados, em ordem crescente de granulometria. Com isto reduz-se o desvio de água e aditivo pelos agregados. A mistura, portanto, compreendeu inicialmente a homogeneização a seco de cimento, sílica ativa, metacaulinita e SM500 (fíler). A esta mistura adicionou-se $95 \%$ da água, misturando até não restarem porções de pó seco. Cinco minutos após a água inicial adiciona-se o superplastificante com o restante da água. Descolou-se todo material grudado nas paredes e pás da betoneira. Formou-se então uma pasta bastante fluida e homogênea. Após uma ação de cinco minutos de aditivo iniciou-se a adição sequencial do restante do material, em ordem crescente de granulometria, até a brita 1, com intervalo de cerca de 2 minutos entre cada material.

Após a homogeneização do concreto, caso haja necessidade, realiza-se o ajuste da água para obter a trabalhabilidade desejada. A trabalhabilidade foi avaliada apenas com 0 ensaio de abatimento de tronco de cone (ABNT NBR NM 67:1998), sendo que se adotou para o concreto de referência uma trabalhabilidade de concreto convencional $(8+/-2 \mathrm{~cm})$. 
Já para o concreto com baixo consumo, devido ao emprego de aditivo com alto poder de plastificação, o abatimento obtido é bem superior, neste trabalho acima de $17 \mathrm{~cm}$.

Após obter o abatimento estipulado realizou-se ainda ensaio de massa específica do concreto fresco (ABNT NBR 9833:2008) e ensaio de teor de ar incorporado (ASTM C231). Avaliaram-se ainda parâmetros qualitativos de acabamento e aparência do concreto, como teor adequado de argamassa, exsudação e segregação.

A etapa final consistiu na moldagem dos corpos de prova necessários para os ensaios mecânicos e de durabilidade, na seguinte sequência:

- três blocos $10 \mathrm{~cm} \times 12 \mathrm{~cm} \times 4 \mathrm{~cm}$ para ensaio de potencial de corrosão;

- uma Placa de $20 \mathrm{~cm} \times 96 \mathrm{~cm} \times 3 \mathrm{~cm}$;

- vinte e dois corpos de prova cilíndricos $10 \mathrm{~cm}$ x $20 \mathrm{~cm}$ confeccionados em fôrma metálica com emprego de desmoldante;

- doze corpos de prova cilíndricos $10 \mathrm{~cm}$ x $20 \mathrm{~cm}$ confeccionados em fôrma de PVC sem emprego de desmoldante para os ensaios onde o desmoldante pode interferir nos resultados;

- quatro prismas de $10 \mathrm{~cm}$ x $10 \mathrm{~cm}$ x $50 \mathrm{~cm}$, sendo 1 sem aplicação de desmoldante. Nos traços com cimento CP III-40-RS moldaram-se três prismas adicionais para avaliação de idade adicional de resistência à tração na flexão.

A moldagem foi realizada utilizando adensamento mecânico, com vibrador de agulha de imersão de $22 \mathrm{~mm}$ de diâmetro. O adensamento foi realizado em camada única, com a agulha na posição vertical, retirada lentamente de modo a evitar aprisionamento de ar. Todos os corpos de prova foram adensados pelo mesmo operador, a fim de manter a uniformidade de aplicação da vibração, tanto em termos de posição, de velocidade de retirada, como de tempo total de aplicação.

\subsection{Ensaios mecânicos}

Com a finalidade de caracterizar os concretos produzidos e correlacionar os resultados de durabilidade com características do concreto endurecido foram realizados ensaios de resistência à compressão, módulo de elasticidade e resistência à tração na flexão. Optou-se pela resistência à tração na flexão devido ao interesse de aplicação deste tipo de concreto na execução de pisos. 
Os ensaios de resistência à compressão e módulo de elasticidade foram realizados nas idades de 7, 28, 63 e 91 dias em corpos de prova cilíndricos de $10 \mathrm{~cm} \times 20 \mathrm{~cm}$, sendo quatro corpos de prova para cada idade na compressão. Três destes ainda foram ensaiados para determinar o módulo de elasticidade, antes da ruptura à compressão. Antes do ensaio tiveram as faces superiores e inferiores rematados por meio de retífica. Após o remate mediram-se as dimensões do corpo de prova (altura e diâmetros) e a massa na condição saturada superfície seca. O ensaio foi realizado em prensa MC8 com capacidade total de $3000 \mathrm{kN}$, utilizando velocidade de carregamento de 0,6 MPa/s.

O ensaio de resistência à tração na flexão foi realizado na idade de 28 dias, e também 63 dias para os concretos com cimento CP III-40-RS, em corpos de prova prismáticos de $10 \mathrm{~cm} \times 10 \mathrm{~cm} \times 50 \mathrm{~cm}$, sendo três corpos de prova para cada idade. $\mathrm{O}$ ensaio foi realizado em prensa ELE, com aplicação de carga nos terços do vão e velocidade de carregamento de $0,2 \mathrm{kN} / \mathrm{s}(0,09 \mathrm{MPa} / \mathrm{s})$. Após a ruptura mediu-se as dimensões na seção fraturada para cálculo da resistência à tração.

Na Figura 22 ilustram-se os ensaios mecânicos executados.
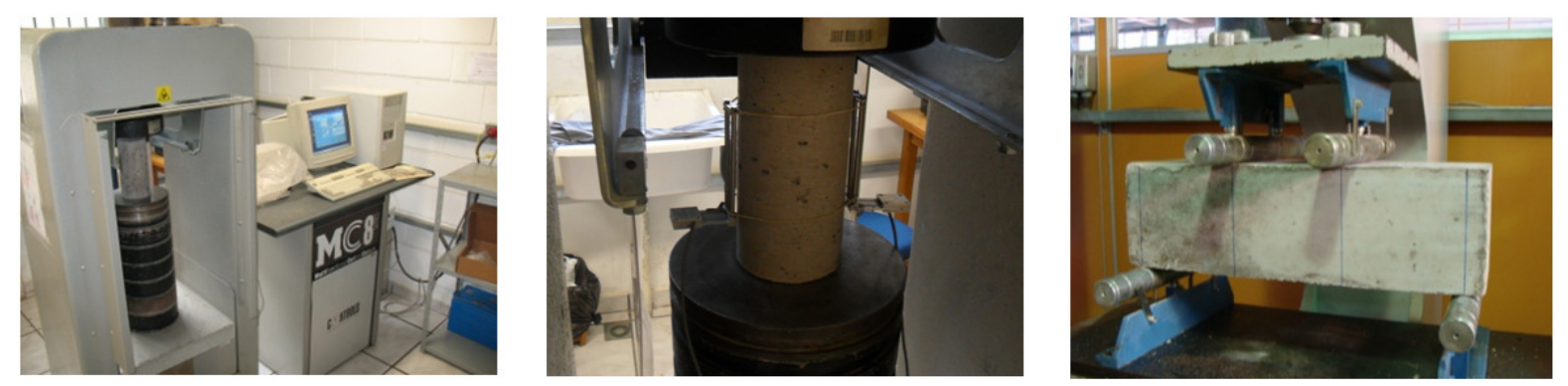

Figura 22 - Ensaios mecânicos: compressão (esquerda); módulo de elasticidade (centro); tração na flexão (direita).

Convém comentar que, para melhor avaliação estatística dos resultados, seria desejável maior número de amostras para cada idade e ensaio. Por motivos operacionais e para reduzir a variabilidade e influência de alterações ambientais, optou-se por moldar cada traço em uma única betonada e os diferentes traços em sequência, de modo que não houvesse diferença de idade considerável entre os concretos testados. Com isto foi necessário limitar a quantidade de amostras por idade e ensaio, devido à limitação de espaço físico, de equipamentos e de tempo. Lembra-se que os resultados mecânicos, mais sensíveis nesta questão, por possuírem caráter muito mais quantitativo que os ensaios de durabilidade, não são o objetivo principal deste trabalho. Em uma possível sequência deste trabalho, com o objetivo de consolidar a técnica de produção de concreto com baixo consumo de cimento, análise mais detalhada é recomendável. 


\subsection{Ensaios de durabilidade}

Citando novamente Aïtcin (2000), não existem ensaio único ou unidade única capaz de descrever de modo completo a durabilidade de um concreto. Muitas vezes um aspecto considerado favorável sob um ponto de vista pode ser negativo sob outro. Por exemplo, cimentos com alto teor de $\mathrm{C}_{3} \mathrm{~A}$ são favoráveis do ponto de vista de ataque de cloretos, porém não o são perante o ataque de sulfatos. Assim, os ensaios propostos com vistas à durabilidade buscaram atender de modo geral alguns aspectos distintos de agressão, com ênfase especial na porosidade e permeabilidade do concreto, por meio dos quais boa parte dos mecanismos de degradação atuam.

Os ensaios realizados também foram restritos, devido à disponibilidade limitada de equipamentos e tempo, considerando que se trata de uma dissertação de mestrado. Ensaios adicionais e mais aprofundados são recomendados para o prosseguimento do estudo deste tema.

Os ensaios escolhidos são descritos em detalhes a seguir.

\subsubsection{Absorção de água por imersão}

O ensaio foi executado baseado nas recomendações da ABNT NBR 9778:2005 (Argamassa e concreto endurecidos - Determinação da absorção de água, índice de vazios e massa específica). O concreto foi avaliado nas idades de 28 e 63 dias, sendo previsto três corpos de prova cilíndricos de $10 \mathrm{~cm}$ x $20 \mathrm{~cm}$ para cada idade. Foram utilizadas fôrmas de PVC isentas de desmoldante para evitar interferência devido à impregnação superficial dos poros do concreto. O procedimento básico do ensaio está descrito seguir.

Os corpos de prova foram curados em câmara úmida até a idade de ensaio. A seguir foram secos em estufa a $105+/-5{ }^{\circ} \mathrm{C}$ por no mínimo 72 horas ou até que a diferença de massa entre duas pesagens sucessivas, em intervalo de 24 horas, fosse inferior a 0,5\% da menor massa. Foram resfriados então à temperatura ambiente em recipiente com sílica-gel. A seguir foram imersos em água em 3 etapas, sendo a primeira durante 4 horas com água até na altura de $1 / 3$ da altura do corpo de prova, uma segunda com mais 4 horas com água até altura de $2 / 3$ da altura do corpo de prova e por fim totalmente submerso até completar 72 horas desde o início do contato com água. A imersão em etapas visa reduzir o risco de aprisionamento de ar no interior do corpo de prova. Após a saturação os corpos de prova são retirados da água e têm a superfície seca com pano úmido até que se obtenha a condição saturada superfície seca (SSS), sendo pesado nesta condição. Determina-se 
também a massa com auxílio de balança hidrostática, para cálculo do volume do corpo de prova na condição SSS.
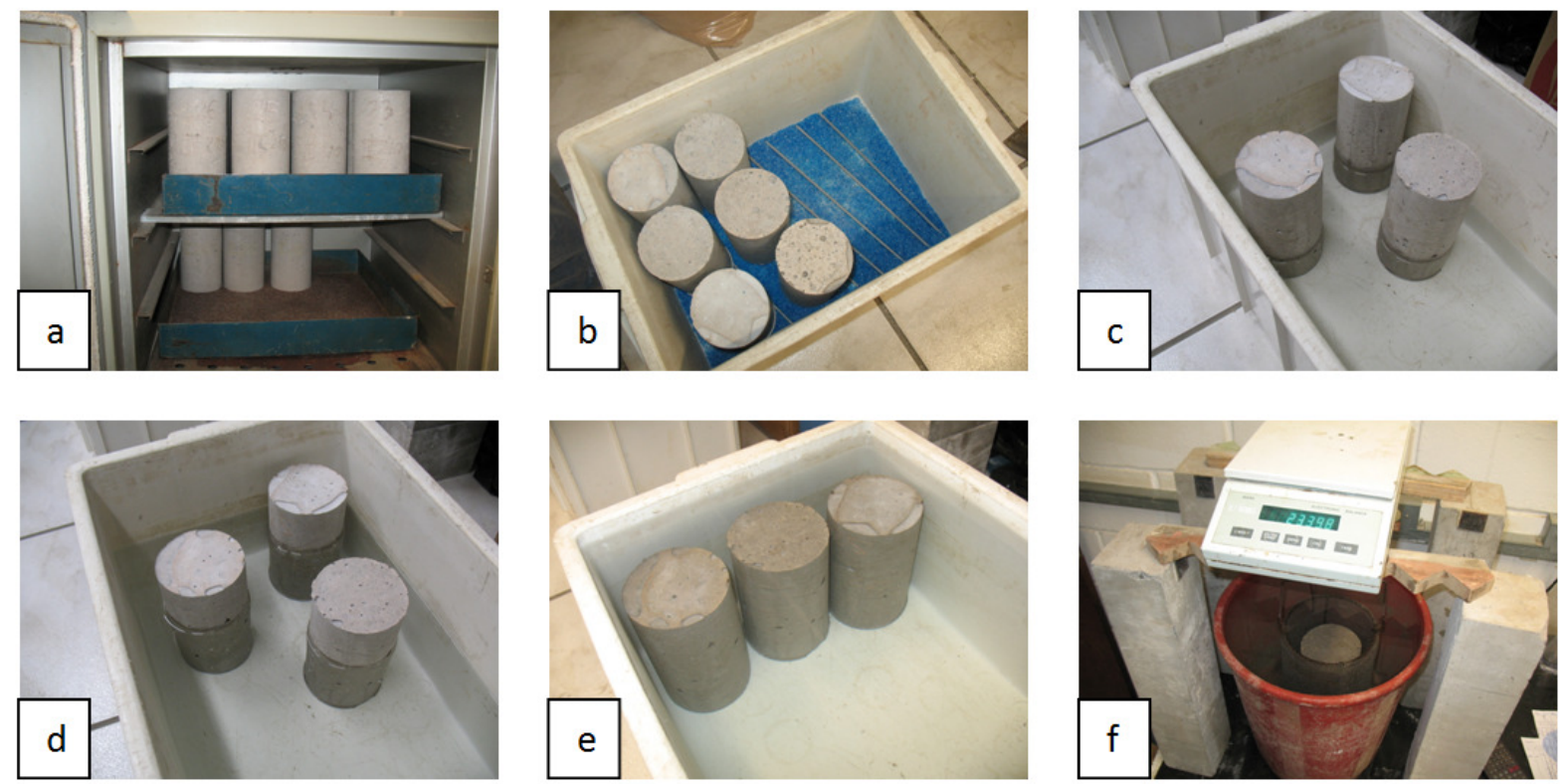

Figura 23 - Sequência de ensaio de absorção por imersão: (a) secagem em estufa, (b) resfriamento em recipiente com sílica-gel, (c, d, e) imersão em três etapas, (f) medição da massa submersa com balança hidrostática.

Em relação a este procedimento básico foram realizadas as seguintes alterações durante a execução:

- Devido a um problema na regulagem da estufa, no ensaio de 28 dias, os corpos de prova foram secos a temperatura de apenas $75^{\circ} \mathrm{C}$, fato que foi detectado apenas após a conclusão do ensaio.

- Entre os resultados de 28 e 63 dias foi verificado que mesmo na secagem a $105{ }^{\circ} \mathrm{C}$ poderia haver problemas de eliminação da umidade interna. Esta investigação está descrita na seção 5.5.1. Devido a estes resultados, na idade de 63 dias foi comparado a secagem durante 3 dias (72 horas) com secagem durante 12 dias (288 horas), sendo porém utilizado apenas um corpo de prova para cada condição de secagem. A NBR 9778:2005 prevê uso de no mínimo duas amostras. Os resultados devem ser avaliados com restrição devido a esta falta de representatividade.

\subsubsection{Absorção de água por capilaridade}

O ensaio foi executado baseado nas recomendações da ABNT NBR 9779:2005 (Argamassa e concreto endurecido - Determinação da absorção da água por capilaridade). 
O concreto foi avaliado nas idades de 28 e 63 dias, sendo previstos 3 corpos de prova cilíndricos de $10 \mathrm{~cm} \times 20 \mathrm{~cm}$ para cada idade. Foram utilizadas fôrmas de PVC isentas de desmoldante para evitar interferência devido à impregnação superficial dos poros do concreto. O procedimento básico do ensaio está descrito a seguir.

Os corpos de prova foram curados em câmara úmida até a idade de ensaio. A seguir foram secos em estufa a $105+/-5{ }^{\circ} \mathrm{C}$ por no mínimo 72 horas ou até que a diferença de massa entre duas pesagens sucessivas, em intervalo de 24 horas, desse menor que 0,5\% da menor massa. Foram resfriados então à temperatura ambiente em recipiente com sílicagel. A seguir foram colocados sobre um estrado e adicionado água até a altura de $5 \mathrm{~mm}$ do fundo do corpo de prova. Este nível foi mantido durante todo o ensaio com variação de +/- $1 \mathrm{~mm}$. Nos tempos de $20 \mathrm{~min}, 45 \mathrm{~min}, 1: 30$ h, $3 \mathrm{~h}, 6 \mathrm{~h}, 24 \mathrm{~h}, 48 \mathrm{~h}$ e $72 \mathrm{~h}$ foram retirados da água, secos na condição saturada superfície seca (SSS) e pesados. Realizou-se ainda a marcação externa do nível que a água atingiu. Após o fim do ensaio os corpos de prova foram rompidos, por compressão diametral, para avaliação do perfil de água interno.
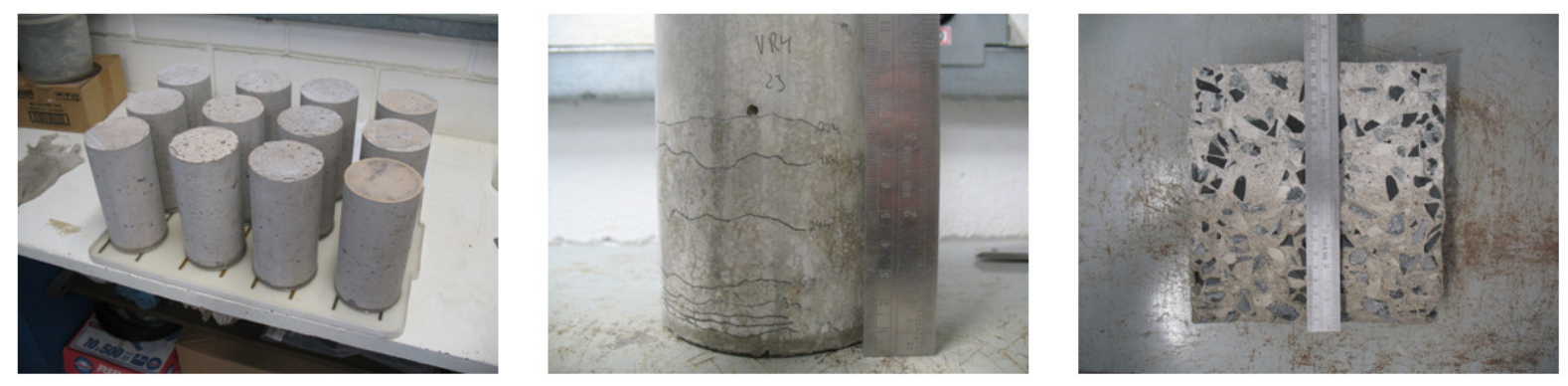

Figura 24 - Ensaio de Absorção por capilaridade: corpos de prova sobre lâmina de água de $5 \mathrm{~mm}$ (esquerda); marcação externa do nível da água capilar (centro); corpo de prova rompido diametralmente para avaliação interna de umidade (direita).

As mesmas mudanças realizadas para o ensaio de absorção por imersão foram realizadas para o ensaio de capilaridade.

\subsubsection{Abrasão}

O ensaio de abrasão foi executado baseado nas recomendações da ABNT NBR 12042:1992 (Materiais inorgânicos - Determinação do desgaste por abrasão - Método de ensaio). O ensaio foi realizado em equipamento tipo Dorry Abrasion Machine, destinado à avaliação de abrasão de agregados de acordo com a norma britânica BSI BS 812-113:1990 (Sampling and testing of mineral aggregates, sand and fillers). As condições foram, porém, adaptadas para reproduzir as exigências da ABNT NBR 12042:1992. 
O concreto utilizado neste ensaio foi moldado na forma de placa, com adensamento e acabamento superficial normal de maneira a não provocar falta ou excesso de argamassa na camada superior. Devido à dificuldade em obter acabamento liso, sem provocar a subida forçada de pasta adicional optou-se por realizar o ensaio de abrasão na superfície inferior do concreto. Com isto pode-se avaliar a resistência potencial à abrasão, isenta de defeitos de acabamento. Deve-se apenas lembrar que em circunstâncias reais, métodos executivos inadequados ou concretos mal dosados, podem conduzir a desgastes maiores, conforme foi comentado na seção 3.7 (Desgaste superficial).

O concreto foi avaliado na idade de 28 dias, sendo utilizadas duas amostras por idade. Com uso de uma serra diamantada, os corpos de prova, nas dimensões de $50 \mathrm{~mm} x$ $90 \mathrm{~mm}$ e $30 \mathrm{~mm}$ de espessura, foram cortados a partir de uma placa de concreto maior. A seguir foram deixadas no ambiente de ensaio até atingir constância de massa, tendo sido registrado o seu peso, as dimensões laterais e a espessura em seis pontos, utilizando paquímetro. Os dois corpos de prova foram então colocados na máquina de abrasão e sobre eles foi colocado um peso de modo a produzir tensão de contato com o disco de abrasão equivalente à exigida pela ABNT NBR 12042:1992 (66 N aplicados em área de $70 \mathrm{x}$ $70 \mathrm{~mm}^{2}$ ). O desgaste dos corpos de prova ocorre pela rotação do anel da máquina e é incrementado pela liberação de um fluxo contínuo de material abrasivo (areia normal IPT50, com grãos entre 0,3 e $0,6 \mathrm{~mm}$ ). A cada $250 \mathrm{~m}$ de percurso o equipamento foi paralisado e os corpos de prova tiveram sua posição girada em $180^{\circ}$, de modo a permitir desgaste mais uniforme. Ao completar 500 e $1000 \mathrm{~m}$ de percurso os corpos de prova foram retirados do equipamento, foi eliminado o pó solto com ajuda de escova com cerdas de plástico e foram determinadas as perdas de massa e a perda de espessura.
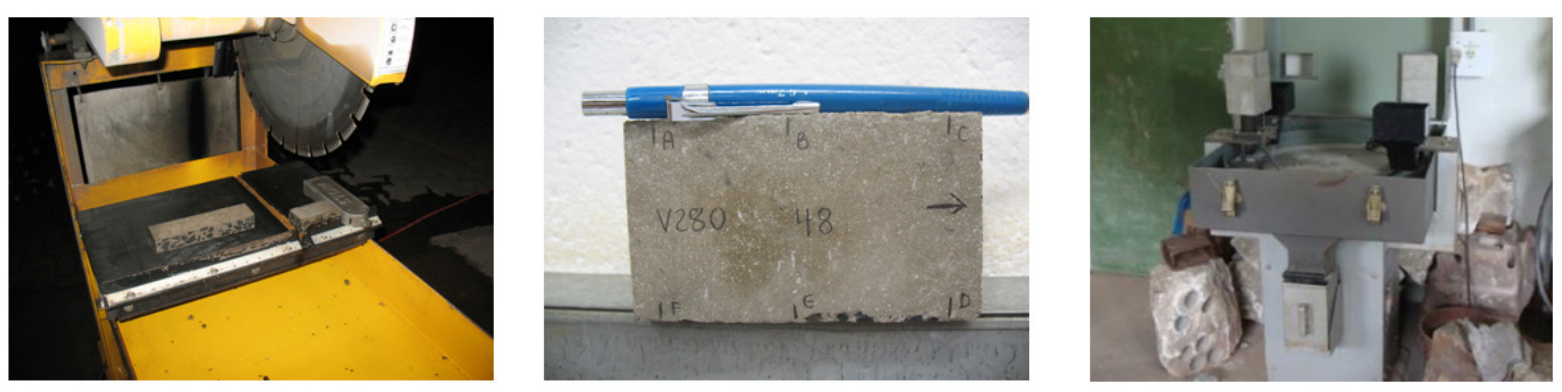

Figura 25 - Ensaio de abrasão: corte dos corpos de prova a partir de uma placa (esquerda); corpo de prova com marcação de pontos de medida de espessura (centro); máquina de abrasão (direita).

Embora a ABNT NBR 12042:1992 recomende a obtenção dos resultados baseados nas medidas de espessura, em ensaio prévio verificou-se que há boa relação entre a perda de espessura medida com paquímetro e a perda de espessura determinada a partir da 
perda de massa, com a vantagem que a medida de massa considera os desgastes por toda a superfície e não apenas em alguns pontos específicos. Sendo assim, os resultados mostrados neste trabalho se referem à perda de espessura calculada a partir da perda de massa, embora tenha também sido registrada a perda de espessura com paquímetro.

\subsubsection{Carbonatação}

O ensaio de carbonatação visa avaliar a porosidade e resistência ao avanço da frente de carbonatação, processo que é primordial para a redução do $\mathrm{pH}$ do concreto e consequente despassivação e corrosão do aço. Para tal foi realizado ensaio acelerado em câmara de carbonatação.

Foram moldados prismas de $10 \mathrm{~cm} \times 10 \mathrm{~cm} \times 50 \mathrm{~cm}$, utilizando fôrma sem aplicação de desmoldante. Os corpos de prova foram curados em câmara úmida até a idade de 28 dias para em seguida passarem por processo de pré-condicionamento.

Como processo de pré-condicionamento optou-se inicialmente por seguir a recomendação do RILEM TC 116 (1999), que consiste em uma etapa de determinação da umidade de equilíbrio e posteriormente secagem dos corpos de prova a serem utilizados no ensaio. Na etapa de determinação da umidade de equilíbrio é necessária a determinação da quantidade total de água evaporável com secagem em estufa a $105{ }^{\circ} \mathrm{C}$. Nesta etapa observou-se a dificuldade em atingir constância de massa adequada para obter resultados confiáveis para o restante do processo. Análise mais detalhada desta dificuldade é descrita na seção 5.5.1.

Em virtude da dificuldade em realizar de modo satisfatório o procedimento da RILEM TC 116 (1999) decidiu-se alterar o processo de pré-condicionamento por um processo mais simples e mais condizente com situações de exposição natural. Os corpos de prova foram dispostos dentro da câmara onde será realizado a carbonatação e mantidos na umidade de ensaio sem, no entanto, fazer injeção de $\mathrm{CO}_{2}$. Permaneceram nesta condição até que se atingisse perda de água diária equivalente a 0,005 \% da massa do corpo de prova. Desta maneira o ensaio de carbonatação iniciou-se com o concreto na idade de 91 dias.

Como condições de ensaio estabeleceram-se: umidade de $65+/-5 \%$, controlada por meio de desumidificador elétrico; temperatura ambiente, variando no período de ensaio no intervalo de $25+/-5{ }^{\circ} \mathrm{C}$; concentração de $\mathrm{CO}_{2}$ de $5 \%$. Esta umidade foi escolhida, pois está no centro do intervalo em que o processo de carbonatação é máximo (50 a $80 \%$ ). A temperatura não foi controlada, pois variações neste intervalo têm pouca influência sobre a velocidade da reação. 
O parâmetro mais difícil de escolher é a concentração de $\mathrm{CO}_{2}$. Não há normatização ou sequer uniformidade ou preferência de uso entre os diversos pesquisadores, sendo utilizadas concentrações de 1 a $100 \%$. Aparentemente há tendência de uso de concentrações mais baixas, chegando a 1 \% recomendado pela CEN EN 13295:2004. Entre os valores baixos mais comumente praticados encontra-se a concentração de $5 \%$. Optouse por utilizar esta concentração como a concentração máxima à qual os corpos de prova seriam submetidos.

A calibração inicial da câmara seguiu o seguinte procedimento. Após a colocação de todos os corpos de prova no interior da câmara foi fechada a porta frontal e ligado o desumidificador. Após um ciclo de funcionamento do aparelho, e estabelecimento da umidade interna desejada, este foi desligado e a porta foi rapidamente aberta para retirada do recipiente onde se acumula a umidade extraída do ar pelo aparelho. Com isto busca-se garantir que a água coletada no ciclo de carbonatação seja oriunda dos corpos de prova e não do ambiente externo. Para isto cuidou-se para realizar a retirada do recipiente de maneira a permitir um mínimo de troca de ar interno com o ambiente externo. O recipiente foi seco e devolvido para a câmara, sendo a porta vedada novamente. Com o registro superior da câmara aberto iniciou-se a injeção de gás carbônico através da entrada inferior na câmara. A vazão de gás, medida por medidor de fluxo previamente calibrado, foi mantida em $9 \mathrm{~L} / \mathrm{min}$ ao longo da injeção. Assim, para a injeção de $5 \%$ de $\mathrm{CO}_{2}$ na câmara de $1200 \mathrm{~L}$, é necessário um tempo de 6:40 minutos. Como a concentração é baixa, o tempo de abastecimento curto, a distância entre a entrada e o registro de saída a maior possível e a densidade do $\mathrm{CO}_{2}$ superior ao do ar natural, pode-se considerar que a entrada de $\mathrm{CO}_{2}$ expulsa apenas ar natural pelo registro superior, obtendo-se a concentração desejada ao final da injeção. Instantes antes do final do tempo de injeção o registro superior é fechado de modo que se alcançasse pressão levemente superior à atmosférica. Adotou-se uma sobre pressão de $20 \mathrm{~mm}$ de $\mathrm{H}_{2} \mathrm{O}$, medida por manômetro externo. Após o fim da injeção liga-se o desumidificador interno. Este tem função de garantir a manutenção da umidade de ensaio e também de promover circulação e homogeneização do ar interno, graças a um ventilador incorporado.

Ao longo do tempo a reação de carbonatação consome o gás carbônico, o que pode ser acompanhado por uma diminuição da pressão. Com isto a concentração diminui lentamente. Para manter a concentração no nível inicial realizou-se diariamente reabastecimento de gás de modo a voltar à sobre pressão inicial de $20 \mathrm{~mm}$ de $\mathrm{H}_{2} \mathrm{O}$, reestabelecendo assim a concentração de $5 \%$ de $\mathrm{CO}_{2}$. 
A cada sete dias foi realizada a troca completa da atmosfera interna da câmara de carbonatação. Neste momento realizou-se também a pesagem dos corpos de prova para acompanhar a variação de massa e a pesagem do total de água eliminada e captada pelo desumidificador. Em alguns destes dias foi também realizada a medida de profundidade de carbonatação. Após as medidas necessárias e eliminação completa da atmosfera existente voltou-se a realizar o procedimento inicial de calibração da câmara para mais um ciclo de carbonatação acelerada.

Ao longo de todo processo foi acompanhada diariamente a temperatura do ambiente, a pressão mínima atingida no interior da câmara e o volume de $\mathrm{CO}_{2}$ injetado.

Para garantir o ingresso de $\mathrm{CO}_{2}$ apenas pelas laterais do corpo de prova realizou-se a impermeabilização dos topos com parafina. Detalhes são mostrados na Figura 26.
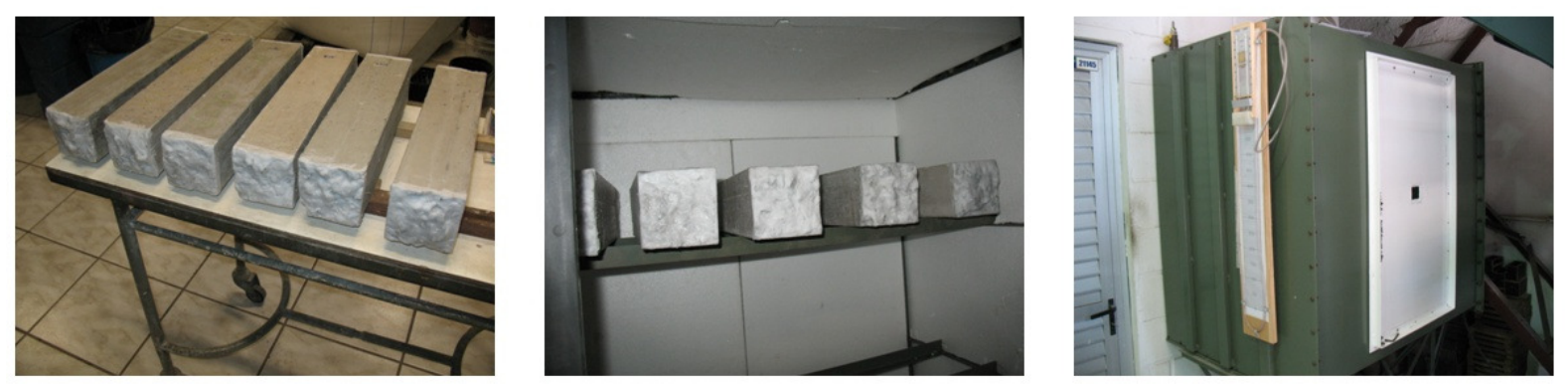

Figura 26 - Ensaio de carbonatação acelerada: corpos de prova prismáticos com topos selados com parafina (esquerda); corpos de prova dispostos no interior da câmara (centro); aspecto geral da câmara, com porta, termômetro e manômetro externo (direita).

A determinação da profundidade de carbonatação foi realizada após 6, 14, 28, 56 e 96 dias na câmara, além da determinação de possível carbonatação inicial.

$\mathrm{Na}$ idade de ensaio os corpos de prova são retirados da câmara e são extraídas fatias de aproximadamente $4 \mathrm{~cm}$ de espessura com auxílio de prensa hidráulica que comprime duas barras de aço $5 \mathrm{~mm}$ contra as laterais do corpo de prova na posição de ruptura. Da superfície fraturada são eliminados o pó e partes soltas com uso de escova de cerdas de plástico e imediatamente a seguir é aspergida solução de fenolftaleína (70 \% de álcool etílico, $29 \%$ de água e $1 \%$ de fenolftaleína). Cuida-se para que a aspersão atinja toda a superfície fraturada, porém sem formar excessos que possam escorrer e distorcer o resultado. Após a retirada das fatias o restante do prisma tem a face recém-fraturada coberta com parafina líquida de modo a impedir a penetração de $\mathrm{CO}_{2}$ através desta face e é recolocado na câmara para um novo ciclo de carbonatação acelerada. 
As fatias tratadas com fenolftaleína são em seguida fotografadas por meio de processo padronizado, que permite a determinação mais precisa da profundidade de carbonatação que a simples medida pontual com paquímetro. As fatias são colocadas em recipiente contendo areia que permite que a fatia seja posicionada com sua face o mais paralelo possível em relação à câmara fotográfica. No contorno da fatia é posicionado papel milimetrado para referência. A câmara fotográfica é fixada em suporte a uma distância constante em relação aos corpos de prova. É mantida iluminação difusa, oriunda de lâmpadas de diversas direções, para eliminar sombras. O disparo da máquina é por meio da função de disparo automático. Detalhes são mostrados na Figura 27.
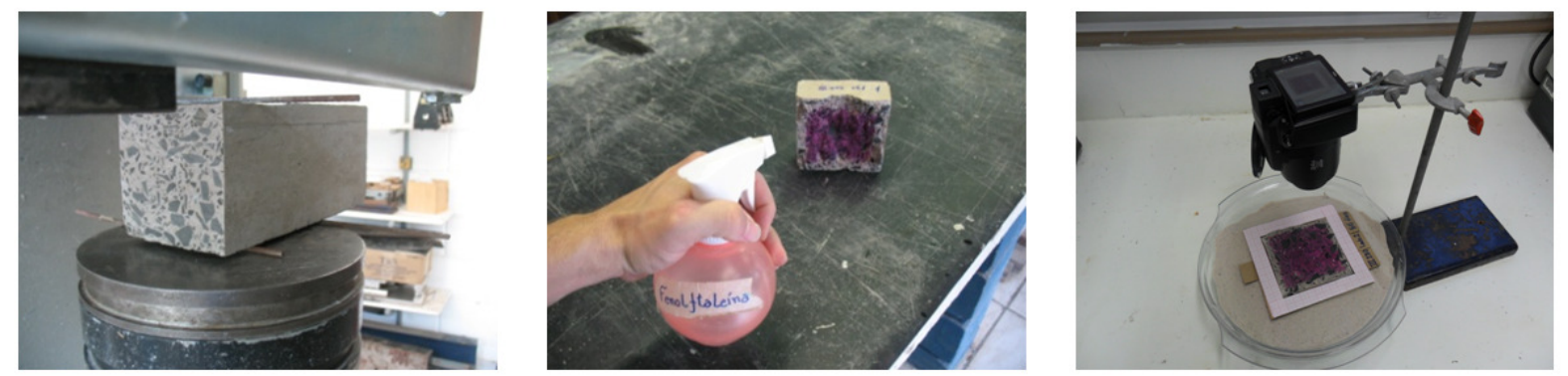

Figura 27 - Determinação da profundidade de carbonatação: extração de fatia (esquerda); aspersão de fenolftaleína (centro); montagem do sistema de fotografia (direita).

Para a determinação da profundidade de carbonatação a fotografia deve ser importada em programa de análise de imagem que permita escalonar a imagem conforme a escala presente, delimitar regiões, calcular área de regiões delimitadas e medir distâncias. Pode-se utilizar programas CAD que permitam a importação e manipulação de imagens ou softwares de análise e tratamento de imagem, como, por exemplo, o Image ${ }^{50}$.

Na Figura 28 mostra-se a sequência de preparação da imagem. Processo muito similar é utilizado pelo grupo de pesquisa do NORIE/UFRGS (PAULETTI, DAL MOLIN e KAZMIERCZAK, 2007). Após a importação, a imagem deve ter seu tamanho ajustado conforme a escala presente (papel milimetrado). Delimitam-se então quatro regiões, referentes às quatro laterais. Os cantos onde há sobreposição do ingresso de $\mathrm{CO}_{2}$ são desconsiderados. Pela medida das áreas destas regiões e das suas larguras é possível calcular a profundidade média de carbonatação. Registra-se ainda a profundidade mínima e máxima em cada região.

\footnotetext{
50 ImageJ: software gratuito e de código aberto que funciona em qualquer computador que tenha a máquina virtual Java 1.4 ou posterior instalada. Há versões disponíveis para Windows, Mac OS, Mac OS X e Linux. Exibe, edita, analisa, processa, salva e imprime vários tipos de arquivo. Maiores informações e download gratuito do programa podem ser obtidos em http://rsb.info.nih.gov/ij/index.html
} 
a)

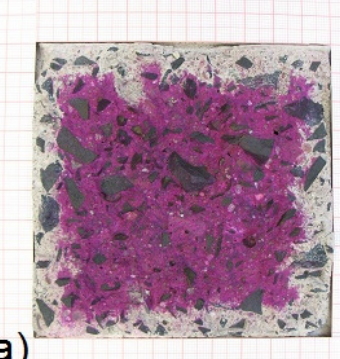

b)

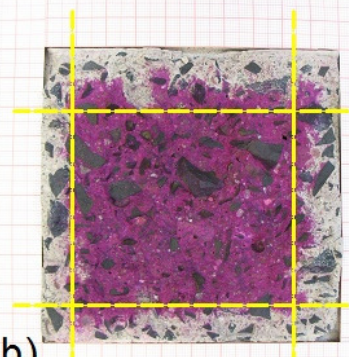

c)

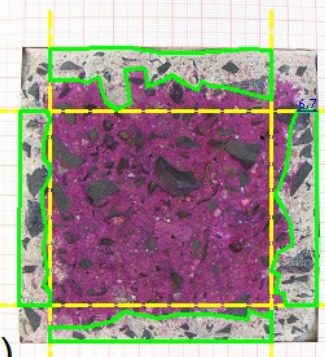

d)

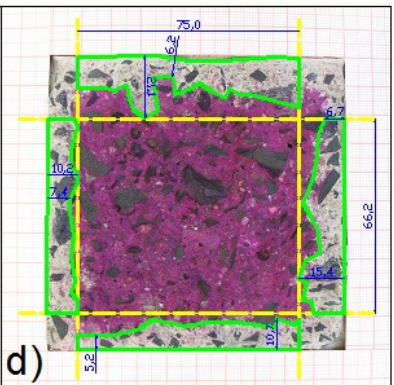

Figura 28 - Análise de imagem para determinação da profundidade de carbonatação. a) importação e ajuste da escala; b) delimitação de núcleo isento de carbonatação; c) delimitação das quatro regiões laterais; d) medição de áreas e profundidades.

\subsubsection{Potencial de corrosão}

O ensaio de potencial de corrosão consiste em medir a diferença de potencial entre um eletrodo padrão, instalado sobre a superfície do concreto, e uma barra de aço inserida dentro do concreto (eletrodo de trabalho). Com isto obtém-se uma ideia aproximada do processo de corrosão. O procedimento é baseado na ASTM C876:1991.

Foram moldados blocos de concreto com 2 barras de aço CA-50 com diâmetro de $8 \mathrm{~mm}$ inseridas. Estas barras possuem apenas um trecho de superfície exposta e o restante isolado, conforme ilustrado na Figura 29. O cobrimento resultante é de 1,6 cm. Os corpos de prova foram curados em câmara úmida até a idade de 63 dias, quando se iniciou o ensaio de potencial de corrosão.

O preparo das barras de aço consistiu das seguintes etapas. Cortou-se de uma mesma barra de aço segmentos com $15 \mathrm{~cm}$ de comprimento. Para eliminação de oxidação superficial existente as barras foram mergulhadas em solução de ácido clorídrico e água destilada na proporção $1: 1 \mathrm{com} 3,5 \mathrm{~g} / \mathrm{l}$ de hexametilenotetramina, por aproximadamente 10 minutos, até que se notou o desprendimento completo da camada de óxido. Para facilitar o desprendimento aplicou-se ultrassom, ainda imerso na solução. A seguir as barras foram retiradas e lavadas em água corrente aplicando escovamento com escova de cerdas de plástico para eliminação da solução ácida, sendo a seguir secos com papel absorvente. Uma inspeção visual verificou se houve a completa eliminação de pontos de oxidação superficial, sendo refeito o processo de limpeza caso houvesse. Depois de secas, as barras são imediatamente armazenadas em dessecador com sílica gel e aplicação de vácuo para evitar nova oxidação superficial. Antes do uso das barras no concreto, realizou-se o isolamento de dois trechos, conforme Figura 30 , com uso de fita isolante em dupla camada. 

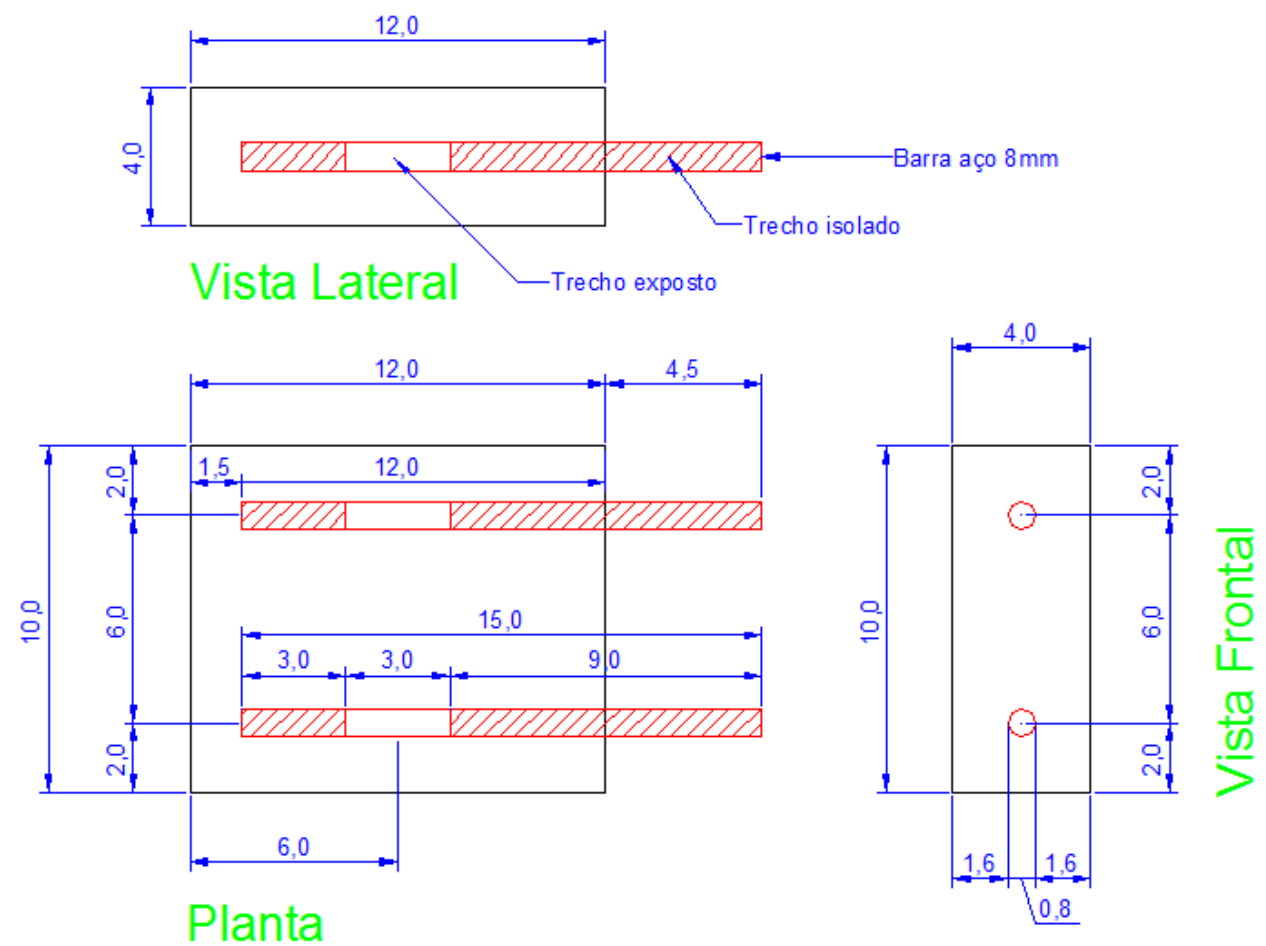

Figura 29 - Dimensões do corpo de prova para ensaio de potencial de corrosão.
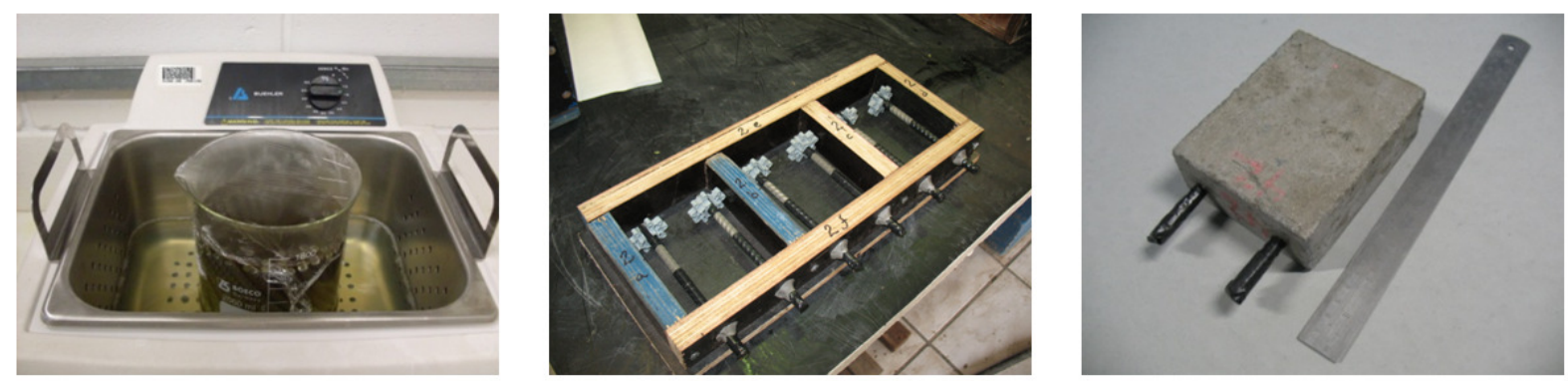

Figura 30 - Preparação das barras no ensaio de potencial de corrosão: limpeza das barras em solução ácida e banho de ultrassom (esquerda); montagem das barras parcialmente isoladas com fita isolante na fôrma (centro); corpo de prova moldado com duas barras imersas (direita).

Para realizar as medidas de potencial é necessária a montagem de um eletrodo de referência. Optou-se por trabalhar com eletrodo cobre/sulfato de cobre cuja montagem seguiu o seguinte procedimento. Um tubo de vidro com diâmetro interno de $26 \mathrm{~mm}$ foi cortado em segmento de $15 \mathrm{~cm}$ de comprimento. A ponta inferior foi vedada com rolha de material cerâmico poroso. O tubo é preenchido com solução de sulfato de cobre saturada, com excesso de cristais precipitados. Nesta solução é imersa uma barra de cobre de $6 \mathrm{~mm}$ de diâmetro e $150 \mathrm{~mm}$ de comprimento, fixada a uma rolha de borracha que veda a abertura superior do tubo, ficando parte da barra para o lado externo. A ponta porosa permite o estabelecimento de contato elétrico entre o interior do eletrodo e a superfície do concreto. 
Para tanto deve permitir a percolação da solução sem que haja cristalização do sulfato nos seus poros. Isto é evitado mantendo a ponta imersa permanentemente em solução de sulfato de cobre saturada. Deve-se preparar um segundo eletrodo no mesmo padrão para servir de comparação. A diferença de potencial entre os dois deve ser inferior a $20 \mathrm{mV}$. Caso este valor seja superado, a barra de cobre deve ser retirada do eletrodo e limpa por meio de imersão em solução diluída de ácido nítrico a 20 \%.

Como se trata de ensaio acelerado, para propiciar penetração mais rápida dos cloretos, aplicam-se ciclos de secagem e imersão parcial em solução de cloreto de sódio. O primeiro ciclo inicia-se após a medida inicial de potencial de corrosão, logo após a retirada dos corpos de prova da câmara de cura úmida. A fase de secagem dura quatro dias e é realizada em estufa ventilada à temperatura de $50{ }^{\circ} \mathrm{C}$. A fase de imersão parcial dura três dias e é realizada em solução com concentração de $\mathrm{NaCl}$ de $3,5 \%$, reproduzindo uma condição média da concentração encontrada na água do mar. Os corpos de prova são submersos apenas até na metade da sua altura, com as barras voltadas para cima e cuidando-se para não haver contato entre as barras e a solução. Os corpos de prova são mantidos separados por uma distância de $2 \mathrm{~cm}$ entre eles. A concentração da solução deve ser verificada rotineiramente e substituída a cada seis ciclos.

O procedimento de medida do potencial de corrosão é realizado inicialmente após a retirada da câmara úmida e depois após a fase de imersão em solução salina dos ciclos de imersão parcial e secagem. Antes da medida, a superfície do concreto deve ser seca superficialmente. Como face de contato com o eletrodo padrão escolheu-se a face inferior do corpo de prova que é mais regular. O corpo de prova é posicionado sobre uma superfície isolante (placa de isopor) e sobre ele na região equivalente ao trecho isolado das barras é disposta uma esponja embebida em solução condutora contendo detergente neutro na concentração de $0,5 \%$. Sobre a esponja é posicionado o eletrodo padrão, mantido na vertical com auxílio de suporte metálico. Um multímetro de baixa impedância é conectado entre o eletrodo padrão (terminal negativo) e uma das barras (terminal positivo). Para medida de potencial deve-se aguardar a estabilização das leituras. Para isto aguardam-se 5 minutos e considera-se como estável quando a diferença entre a leitura aos 5 minutos e uma leitura anterior, aos 3 minutos, difere em menos de $20 \mathrm{mV}$. Caso a diferença seja maior aguarda-se mais tempo, até que a diferença entre 2 minutos seguidos seja inferior a $20 \mathrm{mV}$. Após a estabilização se desconecta e reconecta o sistema, fazendo nova leitura do potencial. Caso a diferença seja inferior a $10 \mathrm{mV}$ da leitura inicial, esta pode ser considerada como correta. Diferenças maiores indicam má conexão do voltímetro com os eletrodos, exigindo que nova leitura seja realizada. Após a medida da primeira barra realiza-se a 
medida na segunda barra do mesmo corpo de prova. Após a conclusão das medidas lava-se rapidamente a superfície para retirar o excesso de solução com detergente, destinando-se o corpo de prova para a fase de secagem. Para facilitar a conexão dos terminais do multímetro nas barras de aço fixou-se um fio de cobre ao trecho externo das barras de aço, realizando a proteção completa do trecho de aço com fita isolante. Na Figura 31 ilustra-se o ensaio.
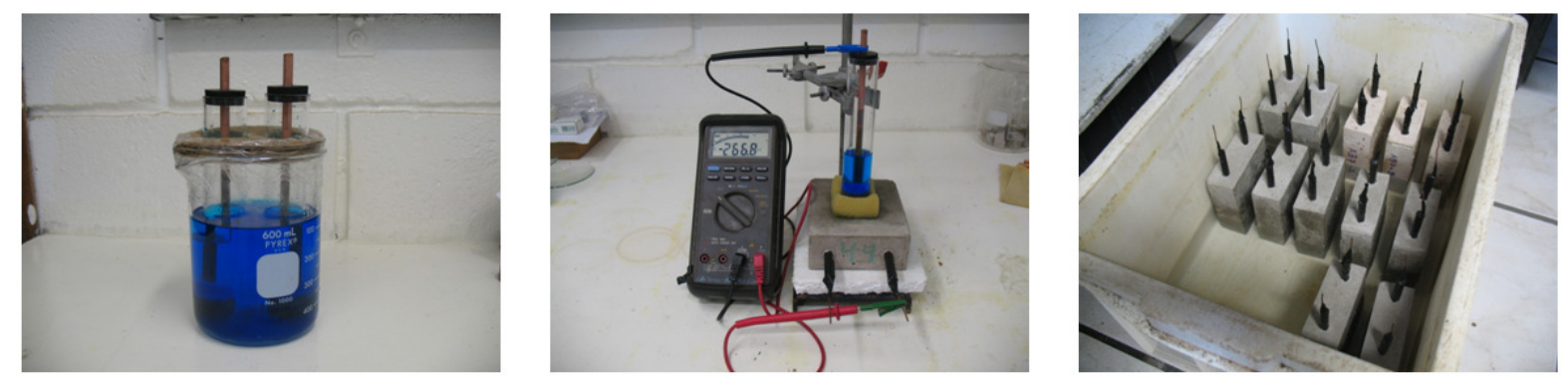

Figura 31 - Medida de potencial de corrosão: eletrodos padrão em solução de sulfato de cobre saturada (esquerda); medição do potencial de corrosão com sistema todo conectado (centro); fase de imersão parcial dos corpos de prova em solução de $\mathrm{NaCl}$ a 3,5 \% (direita).

\subsubsection{Permeabilidade}

Como ensaio de permeabilidade testou-se procedimento destinado à medida rápida de permeabilidade superficial de estruturas de concreto "in loco" sem necessidade de extração de amostras. Este ensaio é denominado de "German Waterpermeability Test" (GWT). O ensaio consiste em fixar sobre o concreto a ser avaliado o aparelho composto por uma câmara de pressão e dispositivos para regular e registrar a pressão aplicada.

Alguns cuidados são necessários para a realização do ensaio. O corpo de prova deve estar saturado para evitar a penetração de água por outros fenômenos além da permeabilidade, como absorção ou capilaridade. Para evitar vazamentos superficiais entre o aparelho e o concreto não é suficiente apenas a pressão de contato obtido com a borracha. Optou-se por fixar um anel de PVC de $0,5 \mathrm{~mm}$ de espessura, colado ao concreto com massa plástica epóxi. Sobre o anel, a borracha de expansão e o fundo do aparelho são aplicados finas camadas de vaselina. A cada ensaio foi realizada cuidadosa verificação para eliminar possíveis vazamentos. Os registros de saída e entrada de água devem estar perfeitamente vedados com uso de fita veda rosca. $O$ anel de ajuste de pressão deve ter a rosca coberta por vaselina para impedir vazamentos. Recomenda-se utilizar água destilada que passou por processo adicional de eliminação de ar dissolvido por aplicação de agitação à vácuo. Antes do inicio do ensaio deve-se eliminar todo ar possível com movimentações e giros do aparato de modo a forçar a saída de ar aprisionado pelo registro de saída. 
A máxima pressão que pode ser aplicada é de 6 bar ( 60 m coluna de água), porém em pressões altas é mais difícil garantir a estanqueidade do aparelho. Optou-se por pressão igual a 3 bar (30 m coluna de água) em todos os ensaios, o que é compatível com boa parte de situações práticas de permeabilidade em reservatórios de água.

É importante esclarecer que o ensaio de permeabilidade executado não corresponde ao ensaio padronizado pela ABNT 10786:1989. O procedimento normatizado prevê uso de amostras mais espessas (15 cm de espessura), com garantia de fluxo unidirecional por meio da selagem das laterais do corpo de prova. Estabelece também que o registro de fluxo seja realizado apenas depois de estabelecida uma vazão constante de saída. Para isto é necessário tempo longo de ensaio e aplicação de pressões altas, chegando até $3 \mathrm{MPa}, 0$ que corresponde a coluna de água de $300 \mathrm{~m}$.

O concreto foi avaliado com idades superiores a 63 dias. Foi moldada uma placa nas dimensões de $20 \mathrm{~cm} \times 96 \mathrm{~cm} \times 3 \mathrm{~cm}$ em fôrma isenta de desmoldante. Foram ensaiadas as faces superiores e inferiores desta placa, com medição em dois pontos de cada lado. A placa foi curada em câmara úmida até a idade de 28 dias, permanecendo depois submersa em água até o dia do ensaio. Previamente sobre a superfície é colado um anel de PVC de $0,5 \mathrm{~mm}$ de espessura e diâmetros internos de $64 \mathrm{~mm}$ e externo de $100 \mathrm{~mm}$. A colagem é realizada com massa plástica epóxi, cuidando-se para não haver contaminação da superfície a ser ensaiada. Antes da colagem e antes do ensaio realiza-se lixamento superficial para eliminar possível camada carbonatada ou com depósito de material solto, sendo a seguir lavado sob água corrente e escovado com escova de cerdas de plástico.

O ensaio consiste no posicionamento da amostra entre as duas presilhas previamente fixadas a uma base de suporte. Sobre a amostra posiciona-se o aparelho. $O$ aparelho é pressionado contra a amostra com o fechamento das presilhas. A pressão das presilhas deve ser regulada por parafusos de ajuste para que se consiga comprimir por completo a borracha de vedação entre a superfície e o aparelho, garantindo assim a estanqueidade. $\mathrm{O}$ anel central deve ser rosqueado até que permaneçam visíveis apenas $3 \mathrm{a}$ 4 voltas da rosca e o micrômetro deve ser recuado até a posição mais aberta, em torno de $22 \mathrm{~mm}$. Em seguida abrem-se os registros e administra-se água através do registro lateral com funil até que a água extravase pelo registro central. Fechar os registro e movimentar o aparato de modo a liberar possíveis bolhas de ar aprisionadas, abrindo em seguida os registros para permitir a saída do ar, processo que deve ser repetido até que não haja mais saída de ar. Os registros são então fechados definitivamente para aplicação da pressão de trabalho escolhida (3,0 bar neste trabalho), iniciando a contagem de tempo. A pressão é aplicada girando o anel central. Durante o ensaio deve-se manter constante a pressão 
indicada no manômetro, o que se obtém com a movimentação do micrômetro lateral. Em intervalos regulares é anotado o tempo e a posição do micrômetro. Observa-se que inicialmente há queda mais rápida de pressão, devido a ajustes internos do aparelho, compressão de algum ar ainda disponível, e preenchimento dos poros superficiais do concreto. Ao passar do tempo o fluxo diminui e tende a ficar mais estável. Na seção 5.5.4 faz-se algumas considerações sobre o ensaio com base nos resultados observados. $\mathrm{Na}$ Figura 32 ilustra-se o ensaio.
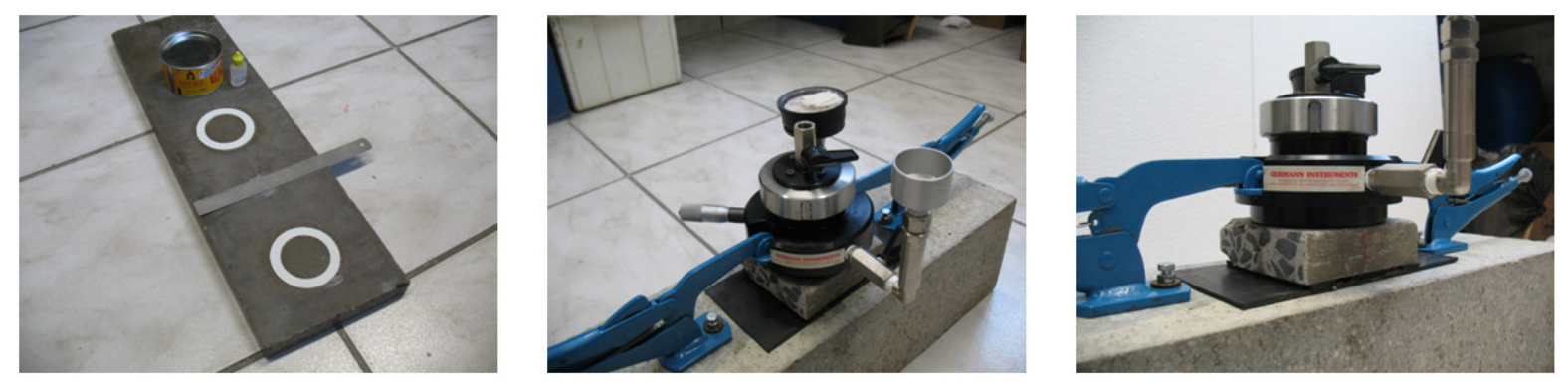

Figura 32 - Ensaio rápido de permeabilidade: placa de concreto com anéis de PVC fixados (esquerda); aparato montado sobre amostra de concreto, mostrando registros superior $e$ lateral com funil, manômetro e micrômetro lateral (centro); vista lateral mostrando aparato comprimido contra o corpo de prova por meio de presilhas (direita).

O volume de água que penetrou no concreto é calculado com base na diferença de medidas do micrômetro cuja seção transversal possui $78,6 \mathrm{~mm}^{2}$. Conhecendo-se o tempo entre duas medidas pode-se obter a vazão de penetração e sabendo que a área de contato é de $3018 \mathrm{~mm}^{2}$ pode-se calcular a velocidade de penetração $q$, pela equação:

$$
\mathrm{q}=\frac{78,6 \times\left(\mathrm{L}_{1}-\mathrm{L}_{2}\right)}{3018 \times \Delta \mathrm{t}}
$$

sendo $L_{1}$ e $L_{2}$ as posições inicial e final do micrômetro e $\Delta$ t o tempo decorrido entre estas duas leituras.

O coeficiente de permeabilidade é calculado pela lei de Darcy:

$$
\mathrm{K}_{\mathrm{p}}=\frac{\mathrm{q} \cdot \mathrm{L}}{\Delta \mathrm{P}}
$$

sendo $q$ a velocidade de penetração, $\Delta P$ a pressão aplicada e $L$ a profundidade em que ocorre o fluxo.

Neste ensaio há dificuldade em se considerar a profundidade $L$, já que o ensaio não é longo o suficiente para atingir o lado oposto e também não há fluxo unidirecional. 0 manual de uso do aparelho sugere espessura de $15 \mathrm{~mm}$. Adotou-se neste trabalho para $L$ valor de $30 \mathrm{~mm}$, equivalente à espessura do corpo de prova, podendo ter ocorrido assim 
superavaliação do coeficiente $\mathrm{K}_{\mathrm{p}}$, ou seja, a permeabilidade na realidade pode ser menor que a calculada.

Os resultados devem ser analisados com cuidado, principalmente se comparados a resultados obtidos por outro tipo de ensaio. Como o ensaio foi utilizado para fins comparativos entre os diversos concretos de baixo consumo de cimento e os concretos de referência, considerou-se a validade do ensaio, sugerindo-se, porém, que em futuras pesquisas seja realizado também o ensaio de permeabilidade segundo a ABNT NBR $10786: 1989^{51}$, o que permitiria inclusive o estabelecimento de correlações entre os dois ensaios.

${ }^{51}$ Os principais parâmetros do ensaio segundo a ABNT NBR 10786:1989, que diferem do ensaio utilizado neste trabalho, são: a garantia de fluxo unidirecional (através da selagem lateral dos corpos de prova), espessura maior dos corpos de prova (mínimo de $15 \mathrm{~cm}$ ), maior pressão $(2 \mathrm{MPa} \approx 200$ m.c.a.) e duração mais longa do ensaio (500 horas $\approx 21$ dias). 


\section{RESULTADOS E ANÁLISES}

\subsection{Ensaios preliminares}

Para definição dos traços empregados foi necessário otimizar o emprego dos diversos materiais. A seguir são apresentados os resultados dos ensaios preliminares que permitiram definir os consumos dos diversos materiais empregados nos concretos definitivos.

\subsubsection{Empacotamento dos agregados}

A primeira fase de empacotamento envolveu os agregados graúdos. A Figura 33 apresenta o resultado deste ensaio. Estabeleceu-se conforme este resultado a proporção entre os agregados graúdos de $60 \%$ de brita 1 e $40 \%$ de pedrisco.

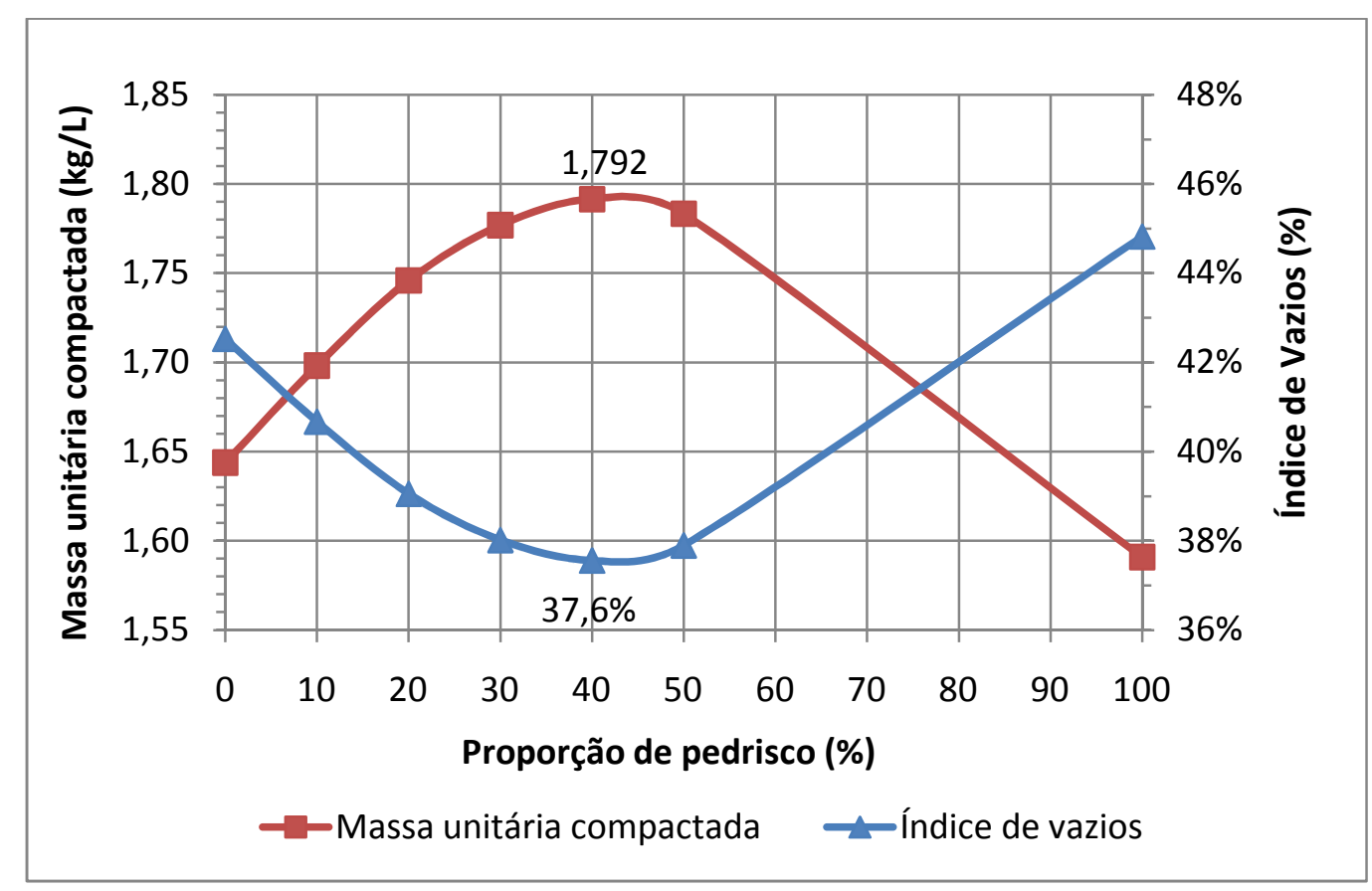

Figura 33 - Massa unitária compactada e índice de vazios em ensaio de empacotamento de agregados graúdos

A segunda fase de empacotamento envolveu os agregados miúdos e o fíler. Esta foi realizada na sequência da maior para a menor granulometria. O primeiro empacotamento entre a Areia 1 e a Areia 2 resultou em proporção $60 \%$ de Areia 1 e $40 \%$ de Areia 2. A mistura nesta proporção com a Areia 3 resultou no segundo ensaio, que indicou o ponto 
ótimo na proporção de $20 \%$ de Areia 3 e $80 \%$ da mistura anterior. Como terceira e última etapa realizou-se o ensaio entre a mistura nestas proporções e o fíler SM500. O resultado destes ensaios, expresso em termos de índice de vazios é mostrado na Figura 34.

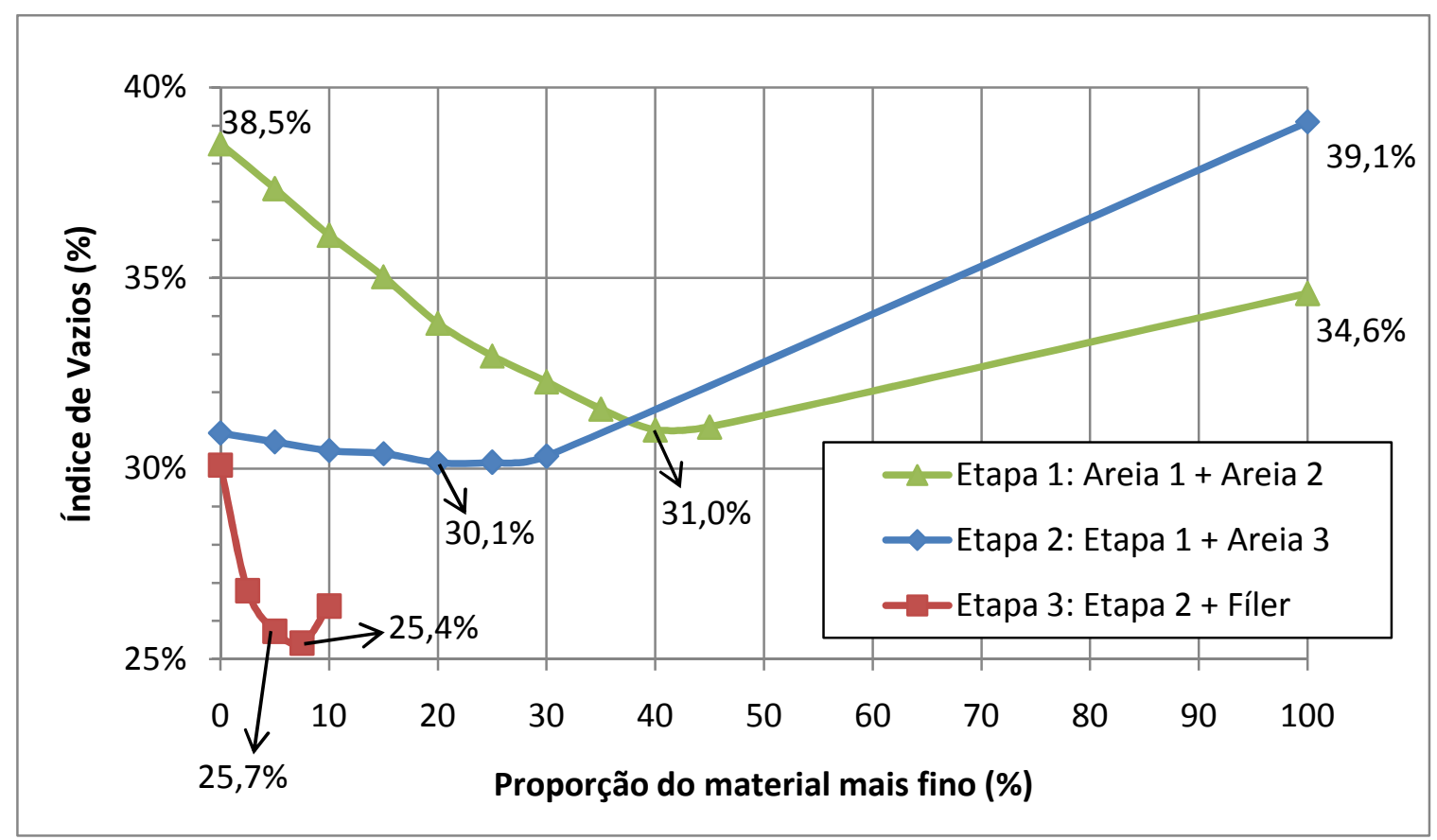

Figura 34 - Índice de vazios resultante em ensaio de empacotamento dos agregados miúdos

Observando o ponto ótimo da Etapa 3 nota-se apenas pequena diferença entre o índice de vazios com 5,0 \% e 7,5\% de fíler. Optou-se por utilizar apenas 5,0 \% por razões econômicas, já que o custo do fíler é relativamente alto. Esta última etapa resultou então em $95 \%$ de material da Etapa 2 e $5 \%$ de fíler. A mistura ideal entre os quatro materiais ficou então definida em 45,6 \% de Areia 1, 30,4 \% de Areia 2, 19,0 \% de Areia 3 e 5,0 \% de fíler SM500, resultando em índice de vazios de $25,7 \%$ e massa unitária compactada de 1,955 $\mathrm{kg} / \mathrm{L}$.

O gráfico da Figura 34 ilustra muito bem o efeito obtido pelo empacotamento. Caso qualquer uma das três areias fosse utilizada individualmente, o que é muito comum em concretos convencionais, o índice de vazios estaria entre 34,6 e 39,1\%, dependendo da areia escolhida. A combinação de duas ou três areias já reduz este valor para quase $30 \%$. O desempenho mais marcante ocorre com a aplicação de fíler, reduzindo o índice de vazios para quase $25 \%$. Em relação a uma areia individual isto representa redução de 9 a $13 \%$ de vazios que deixarão de ser preenchidos com pasta de cimento.

A fase final de empacotamento compreende a otimização entre agregados graúdos e agregados miúdos. O resultado é mostrado na Figura 35. 


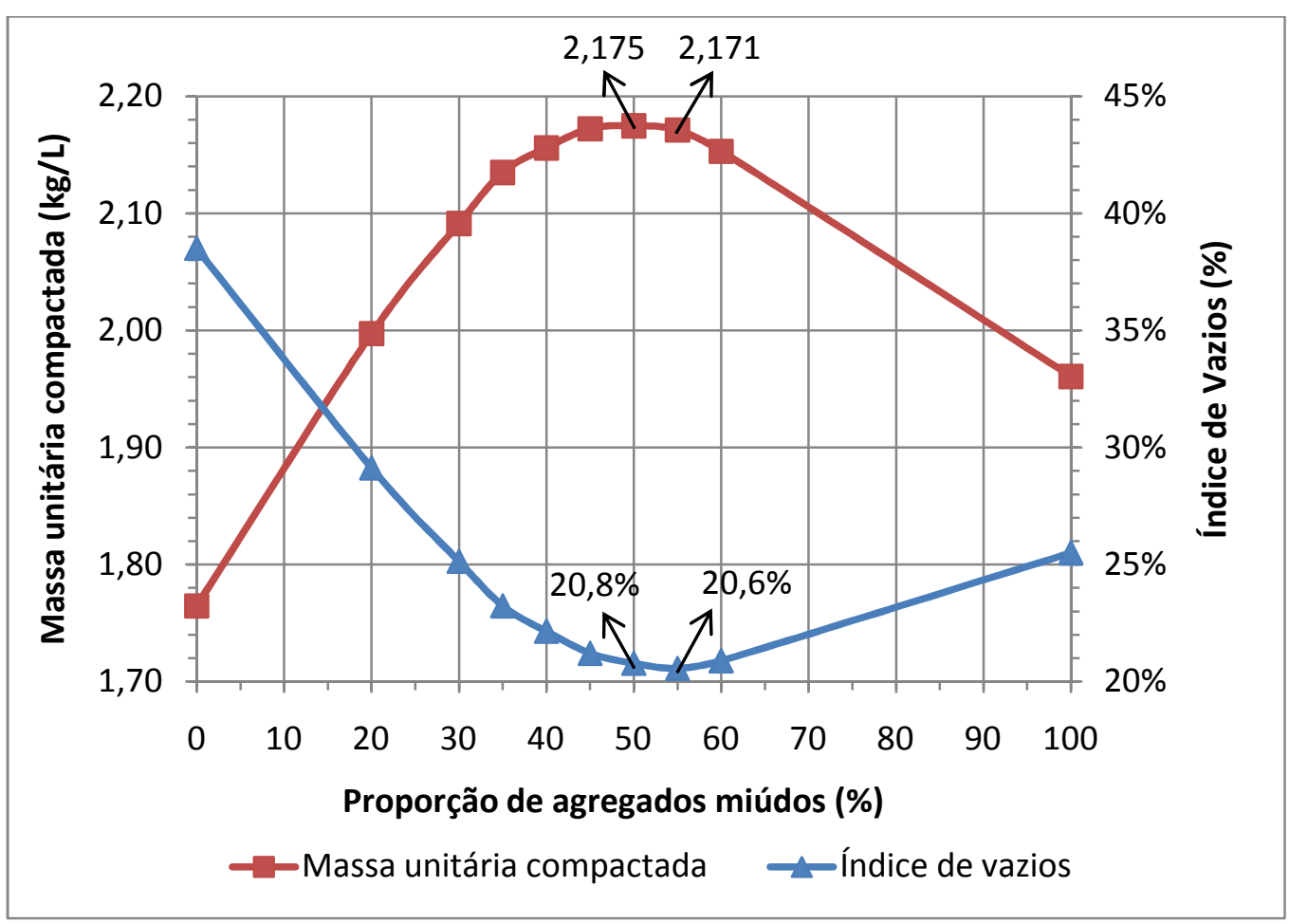

Figura 35 - Fase final do empacotamento com todos os agregados

Com base neste ensaio nota-se um ponto ótimo com proporção de agregados miúdos em $55 \%$, sendo muito pequena a diferença para $50 \%$ de agregados miúdos. Optouse por utilizar apenas $50 \%$ de agregados miúdos por resultar em teor de argamassa um pouco menor e mais próximo do teor de argamassa dos concretos de referência. Para um concreto com $280 \mathrm{~kg} / \mathrm{m}^{3}$ de cimento, por exemplo, o teor de argamassa com $50 \%$ de agregados miúdos fica em $56 \%$, enquanto que com $55 \%$ de agregados miúdos passa para $61 \%$.

Ficou estabelecida então proporção de $50 \%$ de agregados graúdos e $50 \%$ de agregados miúdos, ficando apenas $20,8 \%$ do volume total a ser preenchido com pasta de cimento.

\subsubsection{Avaliação dos aditivos}

Foram avaliados quatro aditivos superplastificantes por meio do ensaio de miniabatimento de tronco de cone. Para escolha do aditivo utilizado nos traços definitivos utilizaram-se como parâmetros: máximo espalhamento, menor perda de espalhamento com o tempo, comportamento mais uniforme e menor interferência na pega. Ente os aditivos testados o que teve melhor desempenho para ambos os cimentos foi o Glenium ${ }^{\circledR} 160$ SCC, recomendado pelo fabricante para uso em concretos autoadensáveis e de alto desempenho. 
Na Figura 36 é apresentado o resultado para o cimento CP V-ARI e na Figura 37 para o cimento CP III-40-RS. As porcentagens de aditivo estão expressas em termos de aditivo total (sólidos + solventes) em relação à massa de cimento.

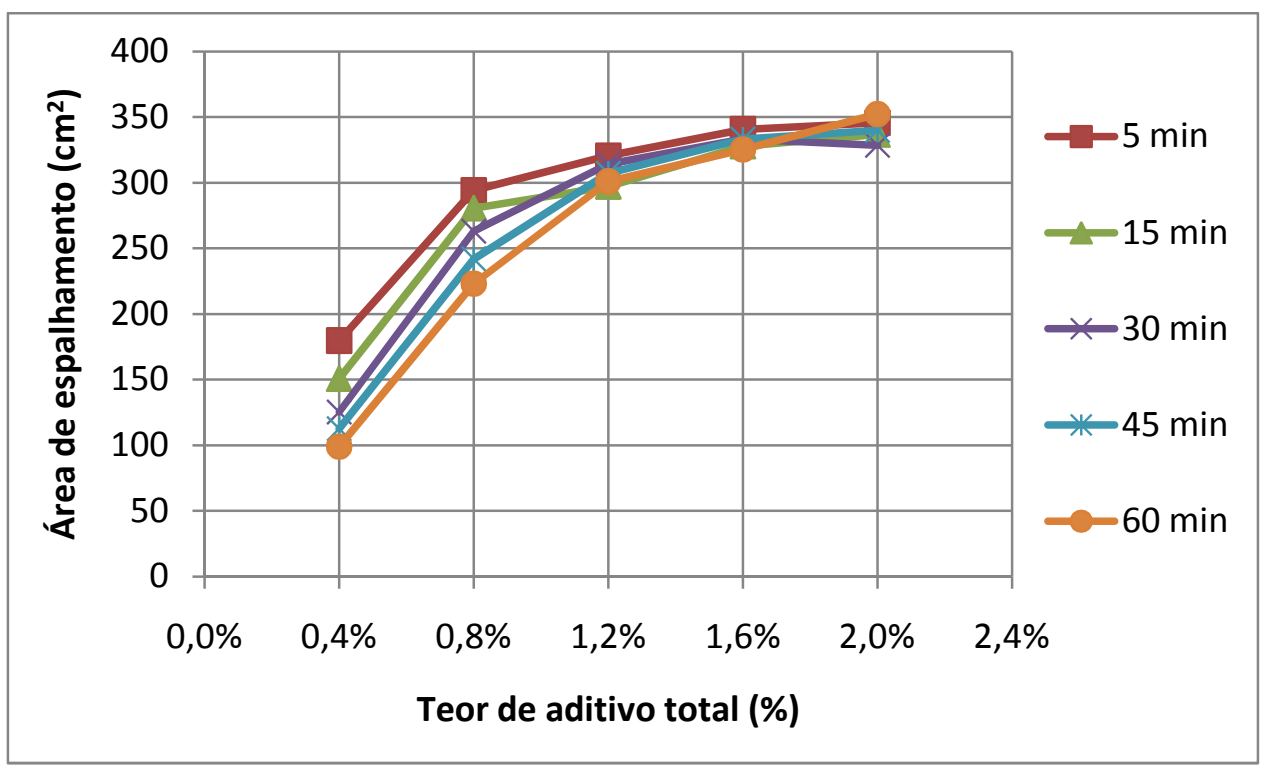

Figura 36 - Ensaio de miniabatimento de tronco de cone com cimento CP V-ARI e aditivo Glenium ${ }^{\circledR} 160$ SCC.

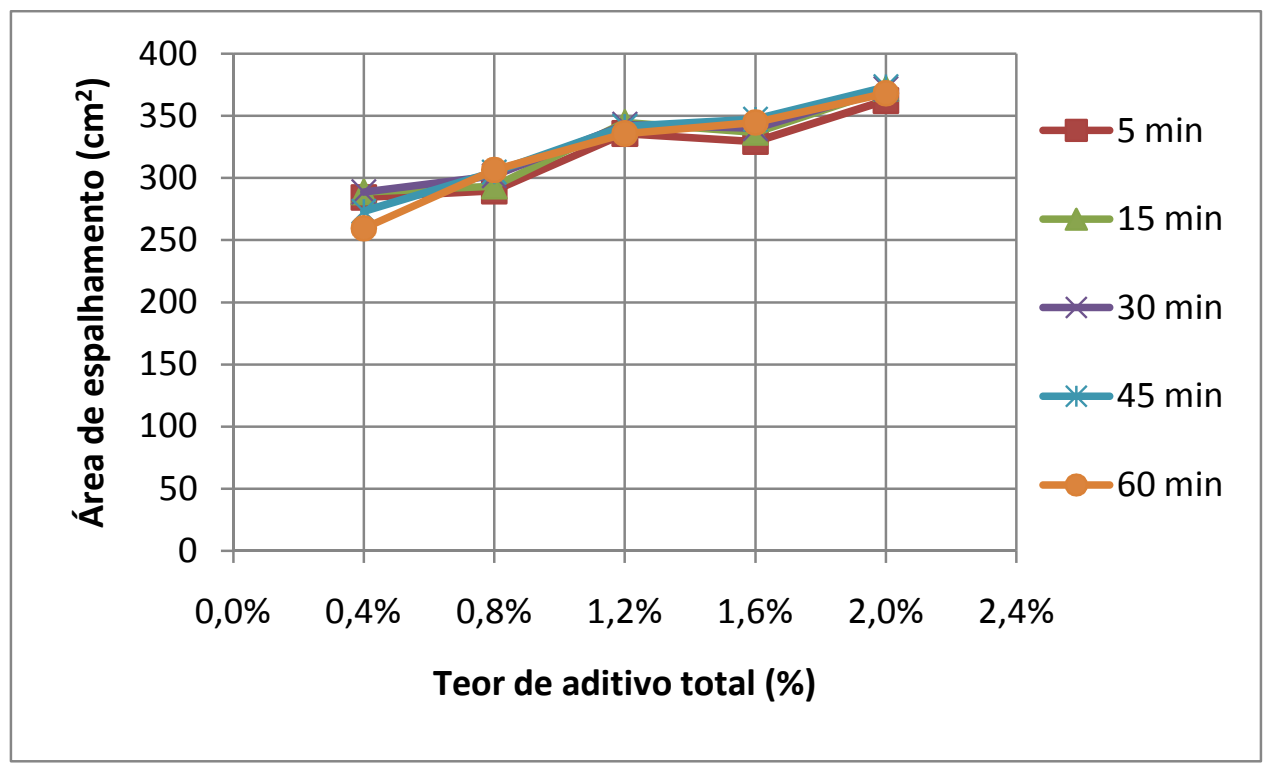

Figura 37 - Ensaio de miniabatimento de tronco de cone com cimento CP III-40-RS e aditivo Glenium ${ }^{\circledR} 160$ SCC.

Cada curva representa um tempo de ensaio. Quanto mais próximas as curvas, menor é a perda de desempenho do aditivo ao longo do tempo. Para o cimento CP III-40-RS há pouca mudança com o tempo, independente da quantidade de aditivo. Para o CP V-ARI 
há alterações mais expressivas com baixo consumo de aditivo. Para maiores consumos ocorre estabilização, sendo que a partir de 1,2\% de aditivo podem-se considerar desprezíveis as perdas de trabalhabilidade até uma hora de ensaio. Pelas curvas pode-se dizer que para o CP V-ARI o ponto de melhor desempenho de aditivo está entre 1,6 e 2,0 \%. Com o cimento CP III-40-RS, maiores espalhamentos são obtidos até mesmo com proporções menores de aditivo e há tendência de aumento aproximadamente linear até os consumos mais altos. Optou-se por limitar o consumo a no máximo 2,0 \% em virtude da possível alteração na pega do cimento, o que é mais importante nos cimentos CP III-40-RS que são notadamente de reação mais lenta.

Vale citar que o fabricante orienta dosagens de 0,2 a 1,2 \% sobre o peso de cimento, ressaltando, porém, que testes laboratoriais e/ou de campo são imprescindíveis para o estabelecimento de dosagens ótimas. A viabilidade de dosagens mais altas foi aqui considerada tendo em vista a necessidade em reduzir ao máximo o consumo de água, o que é primordial para a execução de bons concretos com baixo consumo de cimento. $\mathrm{Na}$ realidade de obra, uma otimização do fator custo pode conduzir à redução neste consumo de aditivo ou até mesmo a troca de aditivo, o que, no entanto, poderá proporcionar aumento no consumo de cimento. Estas questões merecem estudo mais aprofundado, onde o aspecto financeiro seja considerado em conjunto com os critérios técnicos.

Deve-se ressaltar ainda que o ensaio de miniabatimento de tronco de cone deve ser visto como indicativo inicial, principalmente para avaliar a perda de espalhamento com o tempo e permitir comparativo entre os diversos aditivos disponíveis. Ajustes de quantidade de aditivo no concreto podem ser necessários, pois há interação com os demais participantes do traço, principalmente os materiais mais finos, além de um fator água/cimento diferente. Os ajustes devem avaliar também questões de segregação, exsudação e retardo de pega.

\subsubsection{Concretos auxiliares}

Antes da elaboração dos concretos definitivos, foram testados alguns traços auxiliares, com a finalidade de verificar alguns parâmetros e realizar ajustes necessários. Apresentam-se a seguir alguns destes concretos auxiliares, cujas composições estão indicadas no apêndice A.2. Salienta-se que os resultados de resistência à compressão possuem menor representatividade, pois se baseiam apenas na média de dois corpos de prova por idade. 
A primeira avaliação comparou traços com consumos de cimento CP V-ARI entre 231 e 428 kg/m³ (VAux1 a VAux5), empregando a composição granulométrica determinada no ensaio de empacotamento e $2,0 \%$ de aditivo superplastificante Glenium ${ }^{\circledR} 160$ SCC.

Em relação ao consumo de cimento estabeleceu-se ainda proporção de $10 \%$ de adições minerais, referindo-se esta quantidade à proporção volumétrica em relação ao total de aglomerantes. Baseado nos resultados de Melo (2000), e em várias experiências que se seguiram no LMABC, a proporção de $10 \%$ de sílica ativa é capaz de contribuir, com boa relação custo/benefício, principalmente em idades mais altas, com o incremento da resistência mecânica. Pereira (2010) indica ainda que a troca de cerca de $25 \%$ de sílica ativa por metacaulinita melhora o empacotamento entre estes materiais mais finos, obtendo ganhos de resistência em experiência realizada com argamassas. Optou-se por seguir esta mesma recomendação, estabelecendo, portanto, uso de $7,5 \%$ de sílica ativa e $2,5 \%$ de metacaulinita em proporção volumétrica em relação ao total de aglomerantes.

Os resultados (Figura 38) mostram, além das altas resistências, o excelente desempenho obtido em termos de baixo consumo relativo. Boa parte destes resultados está abaixo inclusive do melhor resultado $\left(4,3 \mathrm{~kg} \cdot \mathrm{m}^{-3} \cdot \mathrm{MPa}^{-1}\right)$ detectado pelo levantamento de Damineli et al. (2010). Nota-se que os melhores desempenhos ocorrem com baixo teor absoluto de cimento, abaixo de $300 \mathrm{~kg} / \mathrm{m}^{3}$, onde o resultado do empacotamento é mais efetivo. Com consumos maiores de aglomerantes, o maior volume de pasta acaba distanciando as partículas de agregados, reduzindo a efetividade do empacotamento.

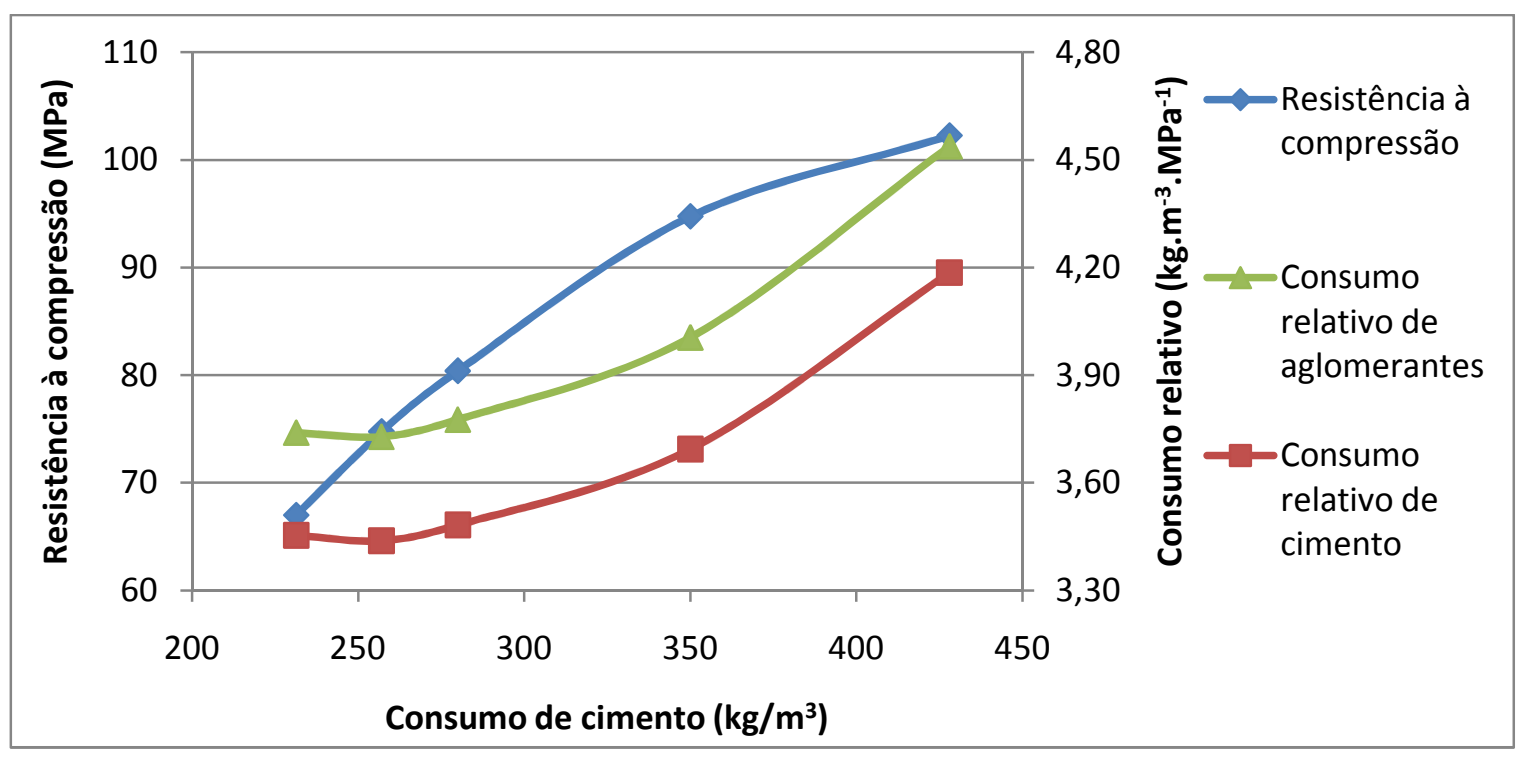

Figura 38 - Resistência à compressão aos 28 dias e consumos relativos de cimento e aglomerantes para os concretos auxiliares VAux1 a VAux5. 
Estes resultados, obtidos com concretos de abatimentos altos (em torno de $200 \mathrm{~mm}$ ), sem apresentação de exsudação e sem retardamento de pega considerável, representaram o primeiro indicativo da viabilidade de execução de concretos de alta resistência com consumos reduzidos de aglomerantes. Apesar do alto empacotamento e do baixo consumo de pasta, considerou-se que a trabalhabilidade obtida pode ser adequada para aplicação do concreto em estruturas reais.

Interessante notar que a relação de água/materiais secos é praticamente constante em todo este intervalo de consumo. Na Figura 39 mostram-se as frações de volume ocupadas pelos diferentes materiais. Ilustrou-se ainda a quantidade de água livre presente, considerando que a relação a/agl de 0,32 é suficiente para hidratar $100 \%$ de pasta sem excessos (MEHTA e MONTEIRO, 2008). O parâmetro relação água/materiais secos pode, portanto, ser aplicado com boa precisão para estabelecer o consumo de água em diferentes traços, dentro da mesma família de concretos.

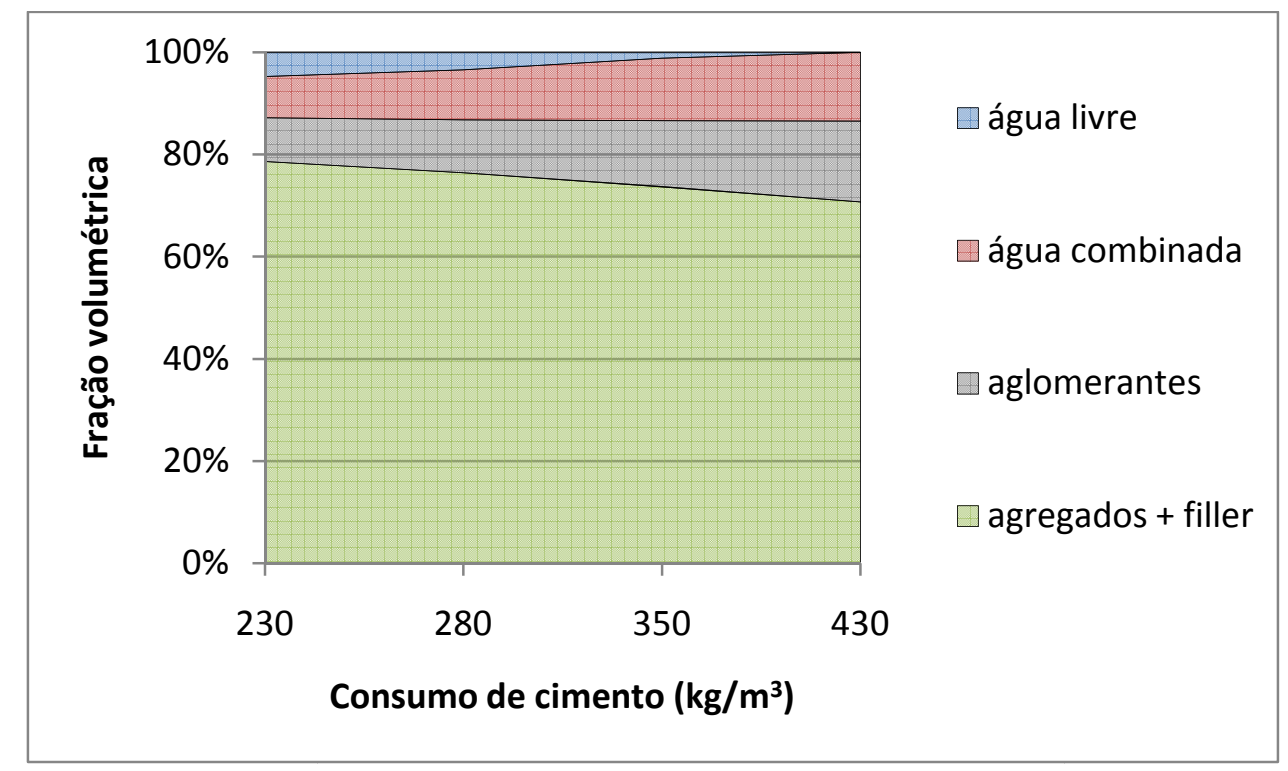

Figura 39 - Fração de volume ocupada pelos diversos tipos de materiais do concreto, em função do consumo de cimento.

A busca por um alto empacotamento exige a utilização de maior diversidade de materiais. A Figura 40 ilustra esta diversidade, adotada nos concretos auxiliares citados acima e posteriormente nos concretos definitivos de baixo consumo de cimento. Os materiais estão ordenados no sentido horário em ordem decrescente de finura (brita 1, pedrisco, areias, fíler, cimento, sílica ativa e metacaulinita), com água e aditivo SP no centro. 


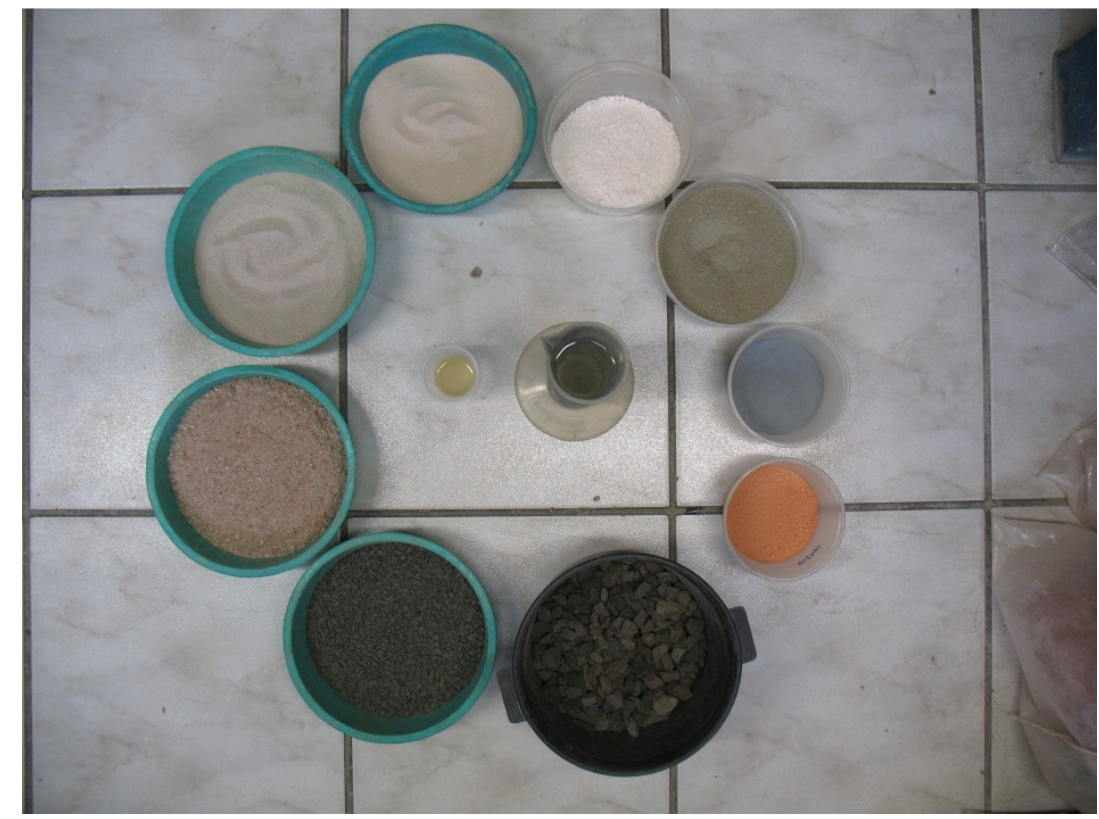

Figura 40 - Materiais utilizados na dosagem dos concretos de baixo consumo de cimento.

Na produção em ambiente de laboratório esta diversidade não apresenta nenhuma dificuldade, porém, na aplicação em campo interfere na produtividade e esbarra em limitações dos equipamentos dosadores, além de aumentar o risco de erros nas medidas dos diversos materiais. Sendo assim, testou-se um traço adicional (VAux6) para analisar a viabilidade de redução de 11 para 9 materiais, eliminando uma das areias (Areia 2) e a metacaulinita. A metacaulinita foi substituída por sílica ativa, em proporção volumétrica, e a Areia 2 por proporções de Areia 1 e 3 de modo a proporcionar menor índice de vazios em ensaio de empacotamento realizado com estas duas areias apenas. Este traço foi baseado no traço VAux2, de $257 \mathrm{~kg} / \mathrm{m}^{3}$ de cimento, que obteve melhor desempenho no ensaio anterior.

Os resultados obtidos com este traço foram equivalentes ao obtido com o VAux2, mostrando que há possibilidade de ajustes no proporcionamento de materiais sem grandes interferências no desempenho. Analisando as granulometrias (Figura 41) nota-se que a presença da Areia 2 preenche o "buraco" próximo a 0,3 mm entre as Areia 1 e Areia 3. Por se tratar de estudo de laboratório, que visa avaliar as possibilidades, optou-se pela curva granulométrica mais contínua, com as três areias. Fica, porém, a sugestão no prosseguimento dos estudos, que a granulometria com apenas duas areias, e outras possibilidades também, sejam testadas, com vistas a aplicações práticas mais simples. 


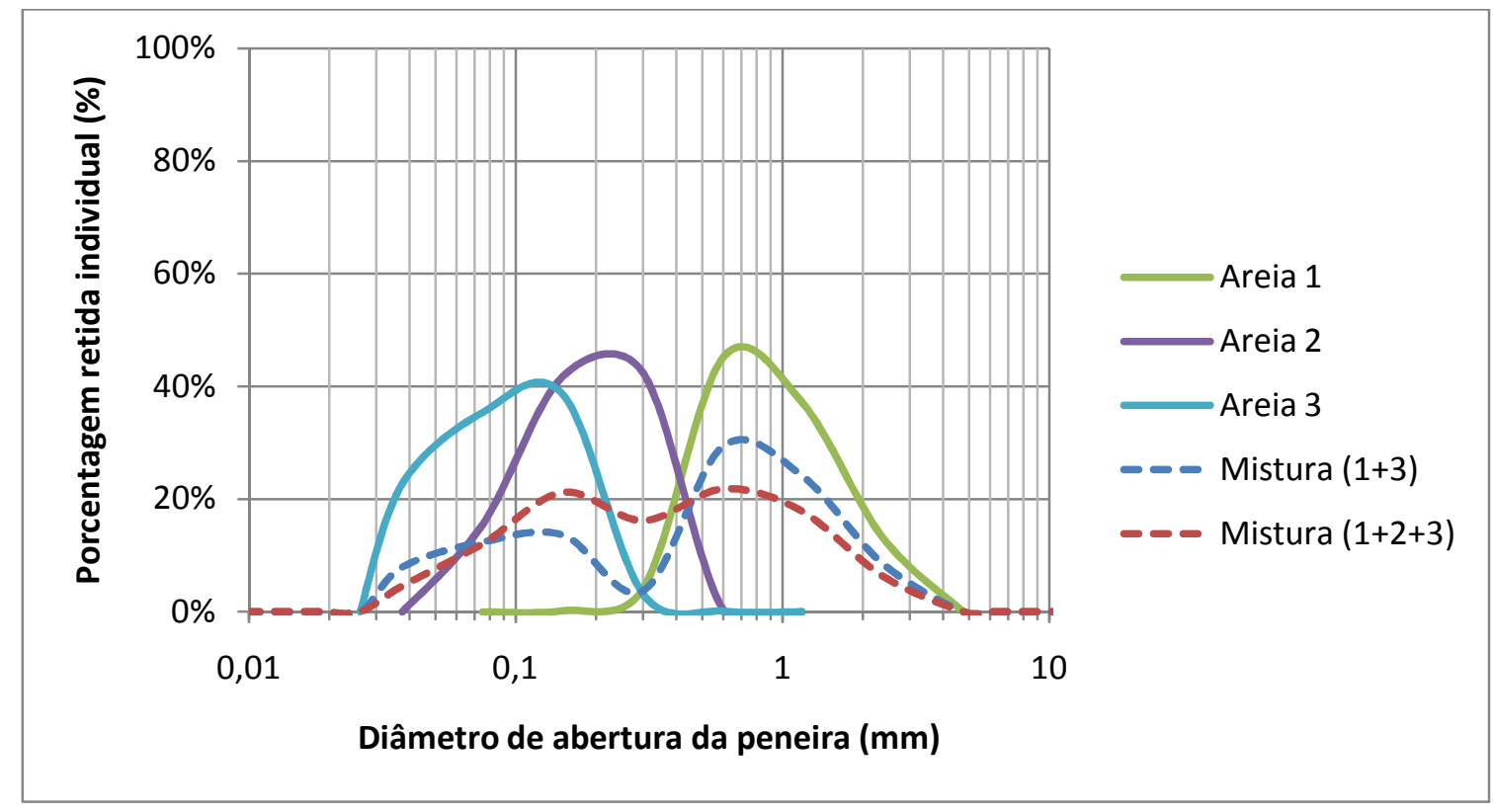

Figura 41 - Distribuições granulométricas das areias e misturas.

Uma tentativa adicional, eliminando também o fíler, que foi substituído por cimento, resultou no traço VAux7. Em relação ao VAux6 observou-se aumento de $10 \%$ da resistência, porém o aumento de cimento foi de $22 \%$, resultando em aumento do consumo relativo de aglomerantes de $11 \%$. Considerando apenas este parâmetro, justifica-se a presença do fíler. Na prática de obra, no entanto, parâmetros de custo podem ser decisivos na escolha dos materiais. O fíler SM500 utilizado neste trabalho apresenta custo relativamente elevado, por ser um material originalmente destinado a segmentos industriais outros que não a construção. Alternativas de fíler como, por exemplo, fíler de calcário, de materiais carbonáticos e até de basalto ${ }^{52}$, precisam ser estudadas em termos de desempenho mecânico, de durabilidade e de custo.

Um teste ainda mais dramático em termos de granulometria dos agregados foi avaliado no traço VAux8. Desenvolvido a partir do traço VAux3, dos agregados manteve-se apenas a Areia 2 e a brita 1. Também se eliminou o fíler, mantendo, no entanto, os aglomerantes e o consumo de aditivo. O traço, além de perder muita coesão, exigiu consumo de água bem maior, com a relação a/agl passando de 0,43 a 0,54. Com isto a queda de resistência foi muito considerável, de 80 para $38 \mathrm{MPa}$. Conclui-se que o uso de

\footnotetext{
52 Sugestão de leitura: PIOVEZAN, I. A. R.; MELEIRO, L. P.; ISA, M. M. Resistência à compressão do concreto autoadensável: influência da atividade pozolânica do calcário e do basalto. Revista Ciência \& Engenharia, Universidade Federal de Uberlândia, v. 15, n. 1/2, p. 95-100, jan.-dez. 2006.
} 
um alto empacotamento, com distribuição granulométrica contínua, é fundamental para a obtenção de altas performances.

Um teste que avaliou consumo maior de adições minerais, de $15 \%$ em vez de $10 \%$ (traço VAux9) não mostrou melhor desempenho de resistência em relação ao consumo de aglomerantes. Comparado com o traço VAux3, que possui quase o mesmo consumo total de aglomerantes, a resistência aos 28 dias foi ligeiramente menor. O aumento de adição, portanto, não se mostrou viável, principalmente do ponto de vista econômico.

Testou-se ainda uma variante na ordem de mistura dos materiais. Nos traços citados até o momento (VAux1 a VAux9) o aditivo foi adicionado após a formação da argamassa. Apenas os agregados graúdos foram adicionados posteriormente, por limitação do equipamento de mistura. No traço VAux10, repetiu-se o traço VAux3, porém formando primeiramente a pasta (aglomerantes e fíler) com o aditivo e somente posteriormente adicionando os agregados miúdos e graúdos. O objetivo foi avaliar se o direcionamento do aditivo para os materiais finos, que são os que realmente precisam ser dispersos, é mais eficiente que a adição com os agregados miúdos presentes, que poderiam desviar assim maior parte do aditivo. Esta sequência também disponibiliza mais água para a pasta. Isto é interessante em função dos baixos consumos de água. A resistência obtida foi apenas ligeiramente superior, porém considerou-se que o processo de mistura foi mais fácil, resultando mais homogêneo, e o concreto apresentou abatimento um pouco maior, mesmo com consumo de água um pouco menor. Esta sequência de mistura foi adotada para os concretos definitivos.

O traço VAux11 avaliou a consequência de consumo de aditivo menor. Segundo o ensaio de miniabatimento de tronco de cone com pastas de cimento CP V-ARI, observou-se melhores resultados com 1,6 a 2,0 \% de aditivo. No traço VAux10 reduziu-se este teor para $1,2 \%$. Comparado com o traço equivalente (VAux3), observou-se a necessidade um pouco maior de água, aumentando a relação água/aglomerante de 0,43 para 0,46 . Isto implicou em perda de resistência de $10 \%$. Teores mais altos parecem, portanto, serem mais eficientes. Esta conclusão, válida no aspecto de resistência deste caso, precisa ser avaliada no aspecto econômico quando aplicada a concretos comerciais. Estudo mais detalhado, avaliando outros teores e outros tipos de aditivos, bem como a influência sobre a resistência em outras idades e sobre outros parâmetros mecânicos e de durabilidade, se faz necessário em cada caso específico. A presença de um engenheiro tecnologista do concreto é de absoluta importância neste momento, inclusive para atribuir melhor desempenho econômico aos concretos empregados. 
Avaliação similar, porém menos ampla, foi realizada com o cimento CP III-40-RS, mostrando que também é possível obter baixos consumos de cimento com traços similares aos testados com CP V-ARI. O melhor desempenho verificou-se com consumos de aproximadamente $260 \mathrm{~kg} / \mathrm{m}^{3}$ de cimento CP III-40-RS, alcançando consumo relativo de cimento de aglomerantes de 4,2 kg.m ${ }^{-3} \cdot \mathrm{MPa}^{-1}$ (traços IIIAux1 a IIIAux4).

Por fim executaram-se ainda alguns traços de concreto convencional, para uso como curvas de dosagem para os concretos de referência. Os diagramas de dosagem destes concretos são mostrados no apêndice A.3.

\subsection{Dosagens}

\subsubsection{Convenção de nomenclatura e representação gráfica}

A nomenclatura adotada para os traços expressa inicialmente o tipo de cimento por meio de numeral romano, V para o cimento CP V-ARI e III para o cimento CP III-40-RS. Em seguida, para os concretos de baixo consumo, segue um número indicando o consumo aproximado de cimento. Para os concretos de referência segue a indicação "R" de referência e o número "4" indicando classe de agressividade equivalente.

Nos gráficos dos resultados será adotada uma convenção uniforme, de modo a facilitar ao longo do texto a identificação dos traços e as análises e comparações. Os traços de baixo consumo serão representados por linhas cheias e os traços de referência por linhas tracejadas. Os traços de baixo consumo serão diferenciados pelo preenchimento do marcador nos traços de consumo absoluto maior $\left(280 \mathrm{~kg} / \mathrm{m}^{3}\right)$ e com não preenchimento nos traços de menor consumo absoluto $\left(200 / 210 \mathrm{~kg} / \mathrm{m}^{3}\right)$. Os traços com cimento CP V-ARI serão representados na cor azul e com marcadores circulares, enquanto que os traços com cimento CP III-40-RS serão representados em vermelho e com marcadores quadrados.

\subsubsection{Traços de baixo consumo de cimento}

Para o primeiro traço de baixo consumo de cimento foi escolhido obedecer ao consumo mínimo de cimento equivalente à classe de agressividade ambiental II, aplicável a ambientes urbanos não litorâneos, o que representa grande parcela das obras atuais. Segundo a ABNT NBR 12.655:2006 deve-se nestes casos utilizar consumo mínimo de 280 $\mathrm{kg}$ de cimento por metro cúbico de concreto. Esta escolha levou ao estabelecimento dos traços V280 (cimento CP V-ARI) e III280 (cimento CP III-40-RS). 
Para avaliar consumos abaixo dos mínimos estabelecidos em normas nacionais e internacionais optou-se por desenvolver um segundo conjunto de concretos. O volume de vazios presente no esqueleto granular de agregados e fíler empacotados, totalizando $20,8 \%$, conforme resultado expresso na Figura 35, deve ser preenchido por pasta (aglomerantes e água), além de um volume de ar aprisionado ou incorporado. Adotando teor mínimo de ar de 1,0\%, haverá necessidade de consumo de pelo menos 19,8\% de pasta, ou seja, $198 \mathrm{~L} / \mathrm{m}^{3}$. Sabe-se, no entanto, que o uso de pasta mínima pode resultar em concretos muito ásperos, pois os agregados ficariam em contato direto, sem uma camada de pasta lubrificante entre eles. Testou-se excesso de $10 \%$ de pasta que permitiu trabalhabilidade adequada. Com base nos ensaios prévios é possível calcular o consumo de aglomerantes e água que preencherão este volume, mantendo a trabalhabilidade necessária. Para o cimento CP V-ARI isto leva a consumo de cimento de aproximadamente $200 \mathrm{~kg} / \mathrm{m}^{3}$, traço este denominado de V200. Para o cimento CP III-40-RS, devido à diferença de massa específica, para a mesma condição de excesso de pasta tem-se consumo de aproximadamente $210 \mathrm{~kg} / \mathrm{m}^{3}$, traço denominado III210.

Como adições minerais adotou-se o uso de $7,5 \%$ de sílica ativa e 2,5 \% de metacaulinita em proporção volumétrica em relação ao total de aglomerantes, conforme discutido nos ensaios prévios.

A proporção entre agregados graúdos, agregados miúdos e fíler seguiu o estabelecido no ensaio de empacotamento. Os ensaios prévios com concretos auxiliares mostraram que é possível obter concretos com adequada trabalhabilidade nestas condições.

Como aditivo optou-se pelo Glenium-160-SCC, na proporção de 2,0 \% sobre os aglomerantes (cimento, sílica ativa e metacaulinita). Optou-se por esta proporção após a análise dos ensaios de miniabatimento de tronco de cone e o desempenho obtido nos ensaios prévios.

O consumo de água foi estabelecido com base nas experiências com os concretos auxiliares, observando-se que um parâmetro muito seguro para estabelecer o consumo de água, dentro da mesma família de concretos e para variações não muito amplas de consumo de cimento, é a relação água/materiais secos.

Estabelecidos estes parâmetros obtêm-se os quatro traços de baixo consumo de cimento, cujas composições estão indicadas na Tabela 12. Os valores de consumo de cimento são ligeiramente diferentes dos valores citados nos parágrafos anteriores, pois já consideram o pequeno ajuste no consumo de água durante a execução do concreto e 
também o índice de vazios determinado experimentalmente. Na Tabela 13 estão indicados alguns parâmetros destes mesmos traços.

Tabela 12 - Consumos de materiais por $\mathrm{m}^{3}$ de concreto dos traços de baixo consumo de cimento $\left(\mathrm{kg} / \mathrm{m}^{3}\right)$

\begin{tabular}{ccccc}
\hline Material & V280 & III280 & V200 & III210 \\
\hline Cimento CP V-ARI & 278,6 & - & 199,2 & - \\
\hline Cimento CP III-40-RS & - & 275,5 & - & 208,0 \\
\hline Sílica ativa & 16,9 & 17,4 & 12,1 & 13,1 \\
\hline Metacaulinita & 6,5 & 6,7 & 4,6 & 5,0 \\
\hline Fíler SM500 & 51,6 & 51,2 & 53,0 & 52,7 \\
\hline Areia 1 & 470,8 & 466,9 & 483,4 & 480,6 \\
\hline Areia 2 & 313,9 & 311,3 & 322,3 & 320,4 \\
\hline Areia 3 & 196,2 & 194,6 & 201,4 & 200,3 \\
\hline Pedrisco & 413,0 & 409,6 & 424,0 & 421,6 \\
\hline Brita 1 & 619,5 & 614,4 & 636,0 & 632,4 \\
\hline Água & 128,3 & 128,9 & 130,5 & 130,7 \\
\hline Superplastificante & 6,04 & 5,99 & 4,32 & 4,52 \\
\hline
\end{tabular}

Tabela 13 - Parâmetros dos traços de baixo consumo de cimento

\begin{tabular}{ccccc}
\hline Parâmetro & V280 & III280 & V200 & III210 \\
\hline $\begin{array}{c}\text { Relação } \\
\text { água/aglomerantes }\end{array}$ & 0,437 & 0,442 & 0,616 & 0,590 \\
\hline $\begin{array}{c}\text { Teor de argamassa } \\
\text { seca }\end{array}$ & $56,4 \%$ & $56,4 \%$ & $54,6 \%$ & $54,8 \%$ \\
\hline Traço 1: & 6,67 & 6,69 & 9,58 & 9,12 \\
\hline $\begin{array}{c}\text { Consumo de cimento } \\
\left(\mathrm{kg} / \mathrm{m}^{3}\right)\end{array}$ & 278,6 & 275,5 & 199,2 & 208,0 \\
\hline $\begin{array}{c}\text { Consumo de } \\
\text { aglomerantes }\left(\mathrm{kg} / \mathrm{m}^{3}\right)\end{array}$ & 302,0 & 299,5 & 216,0 & 226,2 \\
\hline $\begin{array}{c}\text { Relação } \\
\text { água/materiais secos }\end{array}$ & $5,57 \%$ & $5,64 \%$ & $5,70 \%$ & $5,72 \%$ \\
\hline $\begin{array}{c}\text { Teor de } \\
\text { superplastificante }\end{array}$ & $2,0 \%$ & $2,0 \%$ & $2,0 \%$ & $2,0 \%$ \\
\hline
\end{tabular}

\subsubsection{Traços de referência}

Os traços de referência foram desenvolvidos com base nos limites exigidos para atender à classe de agressividade ambiental tipo IV, da ABNT NBR 12.655:2006. Esses 
limites constituem-se de consumo de cimento de no mínimo $360 \mathrm{~kg} / \mathrm{m}^{3}$, relação água/cimento de no máximo 0,45 e resistência à compressão aos 28 dias de no mínimo $40 \mathrm{MPa}$. Estes parâmetros devem ser atendidos simultaneamente.

Como não há outro tipo de recomendação relativo a tipo de cimento, uso ou não de aditivos e recomendações sobre agregados, buscou-se executar estes traços de maneira mais simples possível, tentando reproduzir o que seria realizado por uma obra corriqueira. Os cimentos avaliados foram os mesmos dos traços de baixo consumo de cimento, não sendo utilizados quaisquer tipo de aditivos ou adição mineral e como agregados estabeleceu-se o uso apenas de brita 1 e uma areia. O teor de argamassa escolhido é o teor mínimo suficiente para obter bom acabamento do concreto.

Para o cimento CP V-ARI (traço VR4), com base nos ensaios prévios, notou-se que dentre os parâmetros limites estabelecidos, a relação água-cimento é o parâmetro mais restritivos, sendo necessário, para atingi-la, consumo de cimento maior que o mínimo estabelecido e obtendo-se resistência superior à mínima requerida.

Já para o cimento CP III-40-RS (traço IIIR4) o parâmetro restritivo é a resistência, sendo necessária relação água/cimento inferior à máxima e consumo mínimo de cimento superior ao mínimo exigido.

Tabela 14 - Consumos de materiais por $\mathrm{m}^{3}$ de concreto dos traços de referência $\left(\mathrm{kg} / \mathrm{m}^{3}\right)$

\begin{tabular}{ccc}
\hline Material & VR4 & IIIR4 \\
\hline Cimento CP V-ARI & 426,1 & - \\
\hline Cimento CP III-40-RS & - & 437,4 \\
\hline Areia 1 & 685,1 & 676,6 \\
\hline Brita 1 & 1111,2 & 1114,0 \\
\hline Água & 191,7 & 190,0 \\
\hline
\end{tabular}

Tabela 15 - Parâmetros dos traços de referência

\begin{tabular}{ccc}
\hline Parâmetro & VR4 & IIIR4 \\
\hline Relação água/cimento & 0,450 & 0,434 \\
\hline Teor de argamassa seca & $50,0 \%$ & $50,0 \%$ \\
\hline Traço 1: & 4,22 & 4,09 \\
\hline Consumo de cimento & 426,1 & 437,4 \\
\hline $\begin{array}{c}\text { Relação água/materiais } \\
\text { secos }\end{array}$ & $8,63 \%$ & $8,53 \%$ \\
\hline
\end{tabular}




\subsection{Concreto fresco}

$\mathrm{Na}$ Tabela 16 mostram-se os parâmetros que foram avaliados no estado fresco do concreto.

Tabela 16 - Propriedades dos concretos no estado fresco

\begin{tabular}{ccccccc}
\hline Propriedade & V280 & III280 & V200 & III210 & VR4 & IIIR4 \\
\hline Consistência (K) (cm) & 21,0 & 23,0 & 17,5 & 19,0 & 9,0 & 7,0 \\
\hline Massa específica (kg/L) & 2,52 & 2,51 & 2,54 & 2,52 & 2,46 & 2,48 \\
\hline $\begin{array}{c}\text { Ar aprisionado/ } \\
\text { incorporado (\%) }\end{array}$ & 1,3 & 1,6 & 2,1 & 1,9 & 1,9 & 1,4 \\
\hline
\end{tabular}

Todos os concretos de baixo consumo de cimento alcançaram altos índices de abatimento. Mesmo assim apresentaram grande coesão, sem qualquer indício de segregação. Nas figuras abaixo mostram-se algumas fotos dos concretos no estado fresco, evidenciando alto abatimento sem segregação (Figura 42), teor de argamassa adequado (Figura 43) e bom aspecto de acabamento (Figura 44).

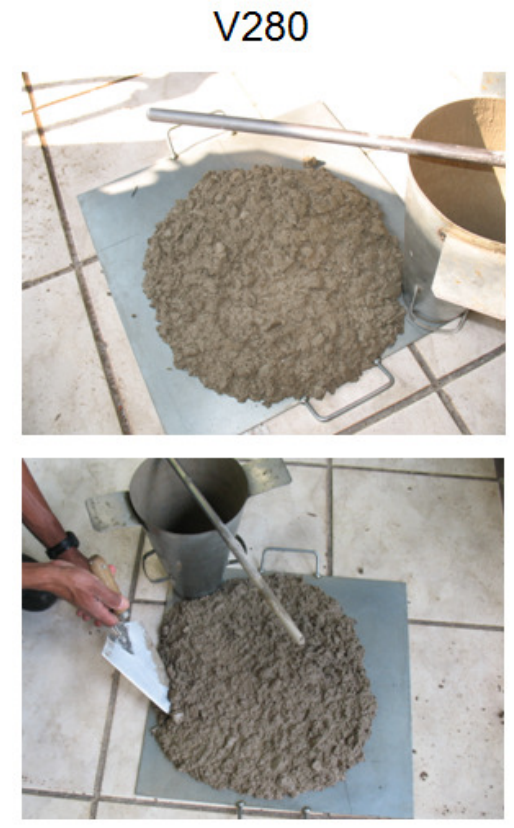

III280

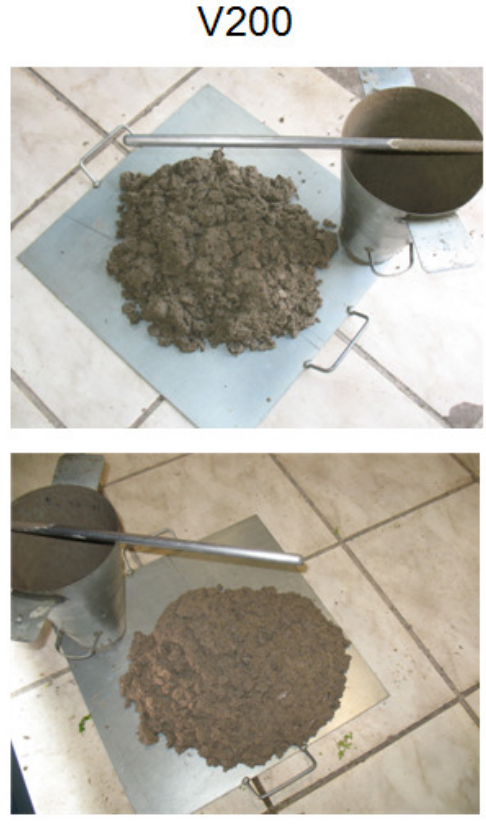

III210
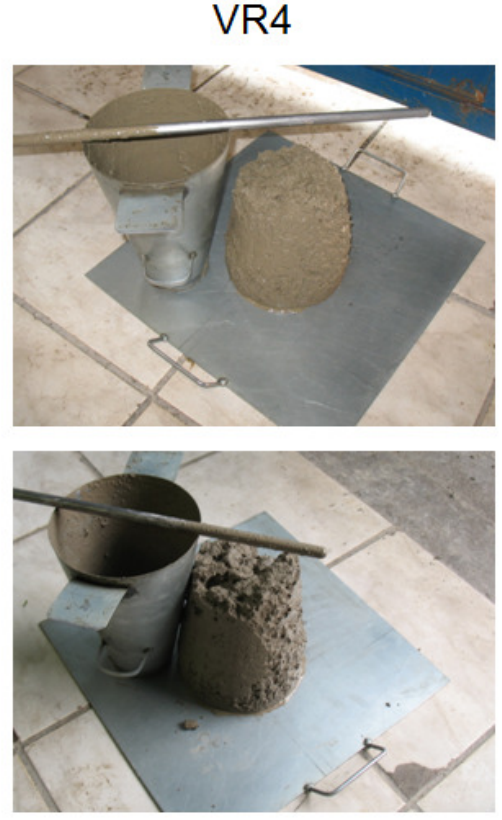

IIIR4

Figura 42 - Aspecto dos concretos no estado fresco após ensaio de abatimento. 


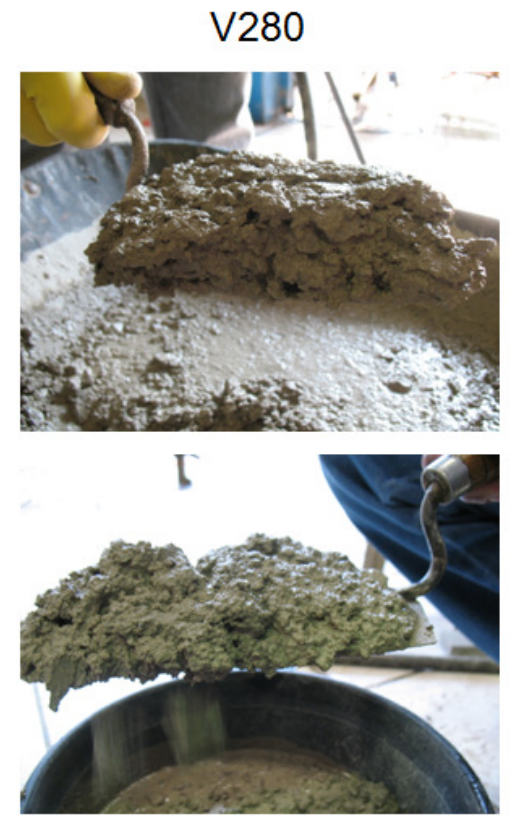

III280
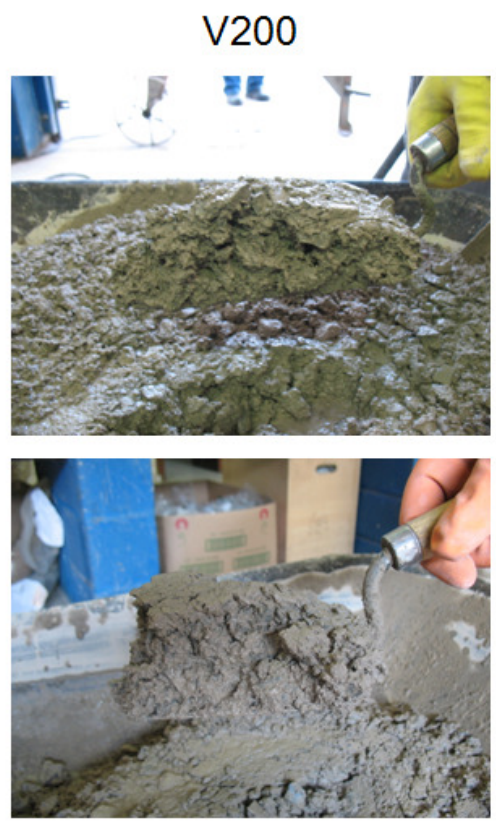

III210
VR4
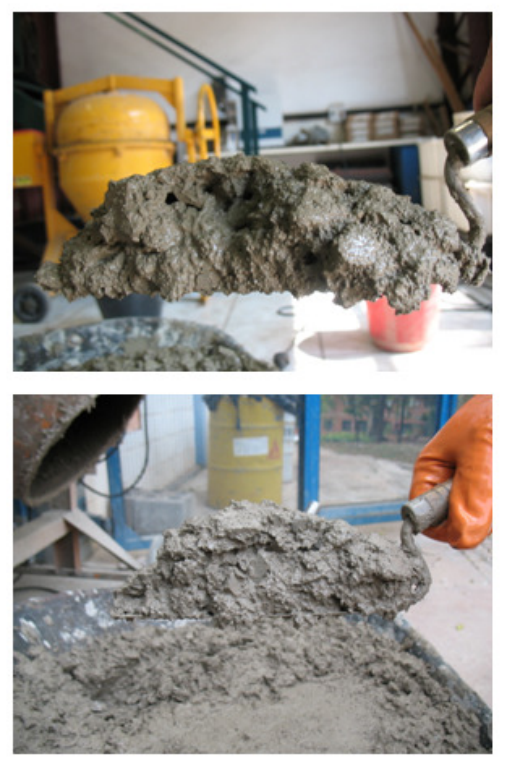

IIIR4

Figura 43 - Aspecto do concreto fresco ao retirar uma porção com colher de pedreiro, indicando teor de argamassa adequado.

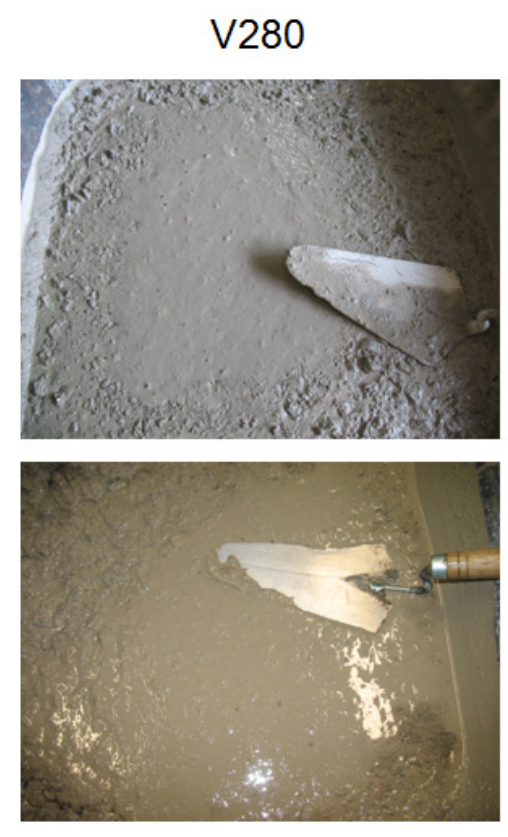

III280

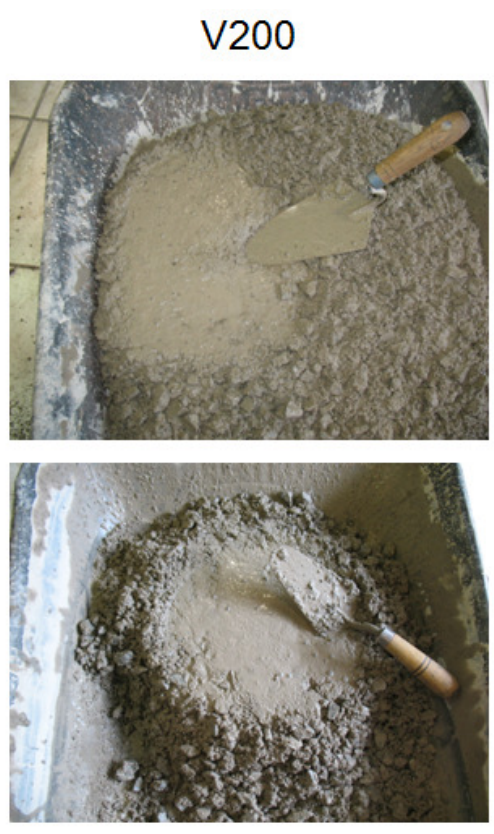

III210
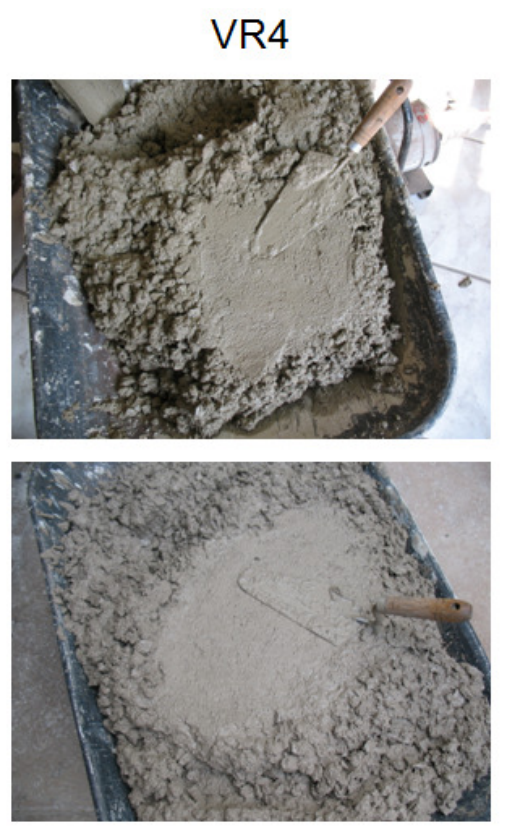

IIIR4

Figura 44 - Aspecto do concreto fresco, indicando bom acabamento após alisamento com colher de pedreiro. 
Deve-se justificar o abatimento levemente inferior dos concretos V200 e III210. Devido ao baixíssimo consumo de cimento decidiu-se não aumentar mais o consumo de água para proporcionar abatimento semelhante ao dos concretos com $280 \mathrm{~kg} / \mathrm{m}^{3}$, pois os traços já mostravam indícios de início de exsudação. Este é um problema que se encontra ao utilizar consumos de cimento, e consequentemente de finos, muito baixos. Neste caso o abatimento menor não significou qualquer prejuízo em termos de acabamento ou trabalhabilidade, mas, caso fosse necessário maior abatimento, uma alternativa seria realizar ajustes nos demais finos presentes, possivelmente com consumo maior de fíler e/ou da areia mais fina. Vale lembrar que a ocorrência de exsudação é sempre indesejável, devendo ser evitada, pois proporciona perda de resistência e durabilidade devido à formação de rede capilar que se estende do interior à superfície do concreto devido à migração da água.

A massa específica mais elevada observada é resultante do melhor empacotamento empregado, substituindo-se pasta de cimento menos densa por agregados mais densos. $O$ valor levemente superior nos concretos V200 e III210, em relação aos com $280 \mathrm{~kg} / \mathrm{m}^{3}$, pode ser justificado pelo acréscimo total de agregados, mesmo tendo a pasta dos concretos V200 e III210 densidade levemente inferior, devido à maior relação água/aglomerantes. A massa específica de pasta de cimento varia entre $1,70 \mathrm{~g} / \mathrm{cm}^{3}$ e $1,85 \mathrm{~g} / \mathrm{cm}^{3}$, dependendo do fator água/aglomerante e da densidade dos aglomerantes. Já a densidade dos agregados, na proporção utilizado neste trabalho está próxima de $2,75 \mathrm{~g} / \mathrm{cm}^{3}$. Para aumentar a massa especifica do concreto pode-se reduzir os vazios ou substituir material menos denso (pasta neste caso) por material mais denso (agregados). Nestas condições um aumento de $0,05 \mathrm{~g} / \mathrm{cm}^{3}$ na massa específica do concreto representa aproximadamente substituição de $5 \%$ de pasta por agregados.

A taxa de ar incorporada é compatível com concretos convencionais, mesmo com os altos índices de superplastificante utilizados, o que mostra que o tipo de aditivo e a concentração utilizada não causou incorporação de ar que exigisse alguma atenção especial.

\subsection{Ensaios físicos e mecânicos do concreto endurecido}

Alguns resultados físicos (massa específica) e mecânicos (resistência à compressão e tração na flexão e módulo de elasticidade) do concreto endurecido são apresentados a seguir, com o intuito de evidenciar os ganhos de desempenho obtidos com as técnicas aplicadas. 


\subsubsection{Massa específica do concreto saturado}

A massa específica do concreto nas idades de ensaio à compressão foi determinada na condição saturada com superfície seca (Figura 45). Os resultados obtidos estão compatíveis com as massas específicas no estado fresco. Os concretos de baixo consumo possuem densidade de aproximadamente $2,54 \mathrm{~g} / \mathrm{cm}^{3}$ e os de referência $2,48 \mathrm{~g} / \mathrm{cm}^{3}$. O aumento da densidade demonstra melhor empacotamento e substituição da pasta de cimento por agregados. Não se nota alteração significativa com a idade, estando as variações dentro do limite de variabilidade de ensaio.

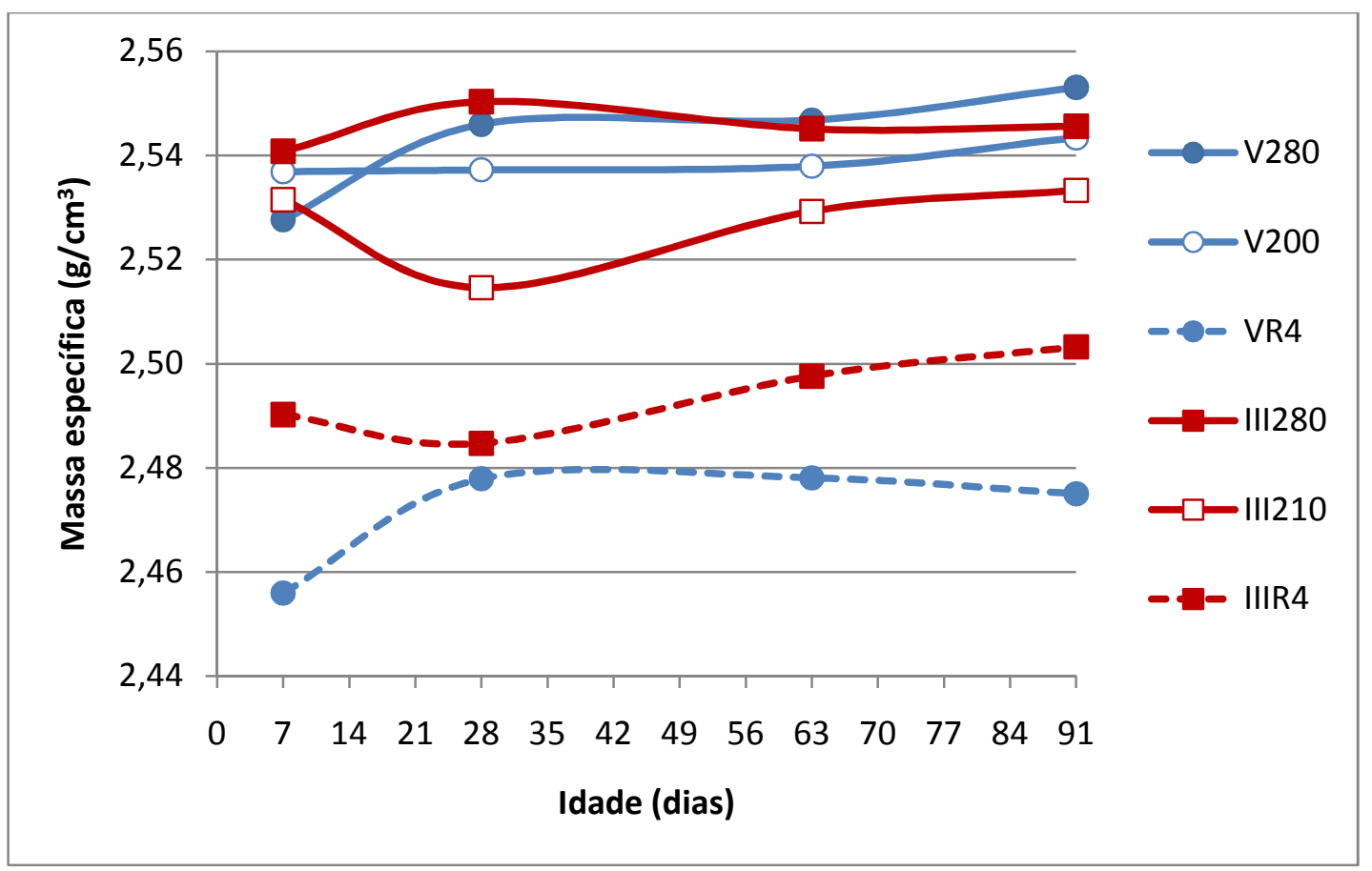

Figura 45 - Massa específica do concreto na condição saturada com superfície seca

\subsubsection{Resistência à compressão}

Na Figura 46 é mostrada a evolução de resistência à compressão dos seis traços estudados. Constata-se inicialmente melhor desempenho dos concretos com cimento CP V-ARI. Para traços similares, mesmo em idades maiores (91 dias), onde se tem maior hidratação da escória, não foram alcançadas resistências equivalentes com o cimento CP III-40-RS.

Os traços de referência praticamente não apresentaram evolução de resistência após a idade de 28 dias. Já os concretos de baixo consumo apresentaram ganhos consideráveis para idades superiores a 28 dias. É interessante notar inclusive ganho muito 
bom para o cimento CP V-ARI, que em geral apresenta pouco ganho após esta idade. De 28 para 91 dias observou-se ganhos de 16 a $22 \%$ nos traços com este cimento, enquanto que com CP III-40-RS os ganhos foram entre 30 a $39 \%$. Estes ganhos são consideravelmente mais altos que os previstos pela fórmula de previsão de ganhos de resistência do item 12.3.3 da ABNT NBR 6118:2003. Esta prevê para concretos com CP V ganho de apenas $9 \%$ e $18 \%$ para CP III. O maior ganho nos cimentos CP III se justifica pelo fato da hidratação da escória ser mais lenta.

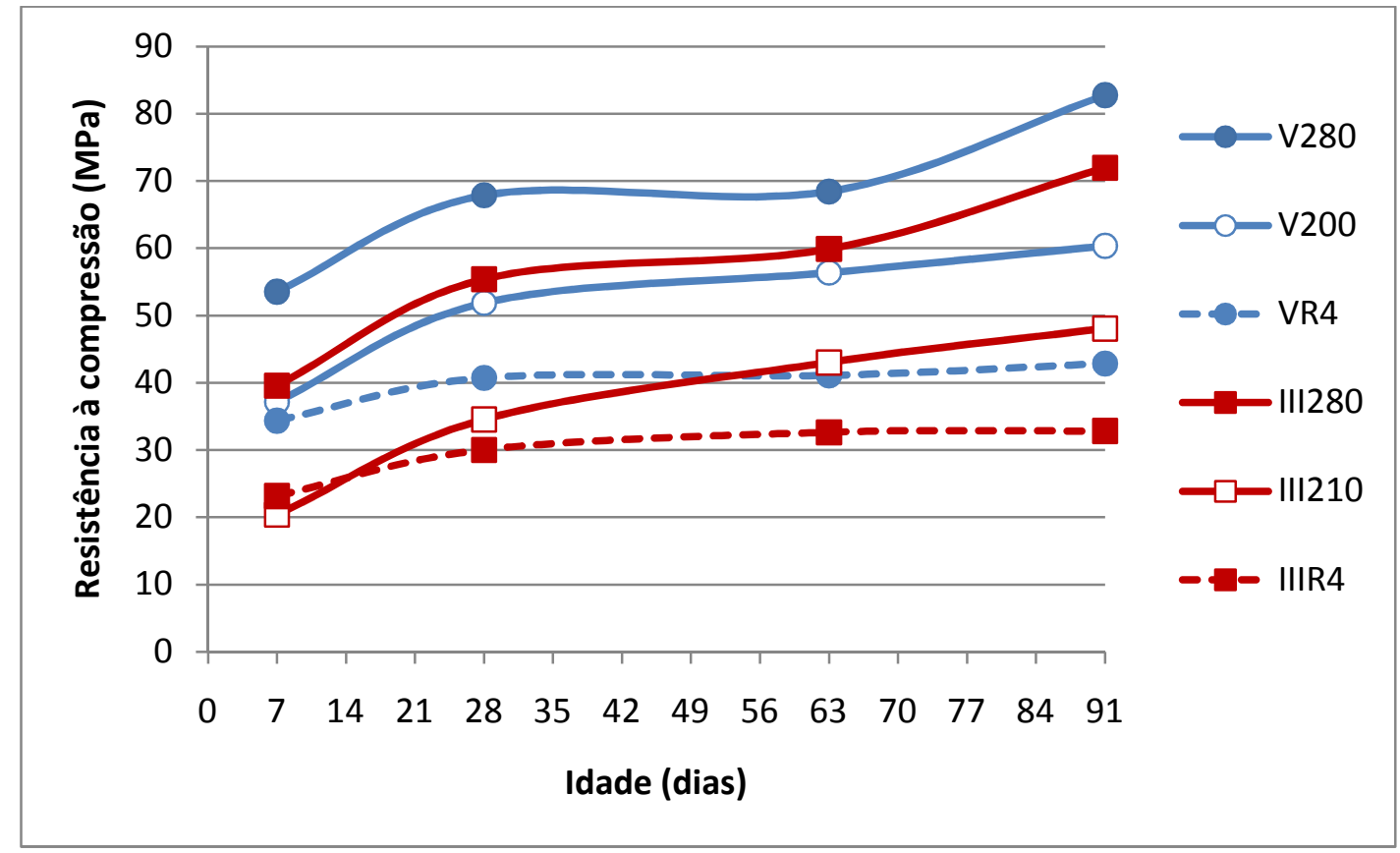

Figura 46 - Evolução da resistência à compressão com a idade dos concretos estudados

Os traços de baixo consumo superaram a marca de $40 \mathrm{MPa}$, resistência considerada limite para classe de agressividade IV da ABNT NBR 12.655:2006. Apenas o traço com $210 \mathrm{~kg} / \mathrm{m}^{3}$ não atingiu este limite aos 28 dias, porém superou-o em idades maiores.

É necessário neste ponto fazer um comentário a respeito do traço de referência com cimento CP III-40-RS. Embora tenha sido previsto pelos ensaios preliminares que se obtivesse resistência mínima de $40 \mathrm{MPa}$ aos 28 dias, este traço ficou abaixo do esperado. $\mathrm{O}$ consumo relativo aos 28 dias ficou em $14,7 \mathrm{~kg} / \mathrm{m}^{3}$, valor alto comparado com os ensaios prévios. Ensaios posteriores confirmaram que não houve nenhum erro na confecção do traço. A rigor, portanto, este traço, embora atenda os critérios de durabilidade no tocante a consumo de cimento e relação água/cimento da NBR 12.655:2006, deveria ser rebaixado à categoria III, pois atingiu apenas resistência mínima de $30 \mathrm{MPa}$ e não $40 \mathrm{MPa}$. 
Uma possível justificativa está em problemas no cimento. Ensaio de resistência característica do cimento mostrou que o CP III-40-RS, que deveria atingir $40 \mathrm{MPa}$ aos 28 dias está atingindo valores de apenas 36,8 MPa. A influência parece ser maior no concreto convencional onde se tem consumos de cimento maiores e maior dificuldade em deflocular o cimento. Nota-se que este problema não foi observado nos traços de baixo consumo de cimento que, embora obtendo menores resistências que o $\mathrm{CP} V$-ARI, atingiram boas relações consumo/resistência. Sugere-se para o prosseguimento do trabalho que sejam realizados novos ensaios com novo lote de cimento que atenda os limites mínimos de resistência do cimento.

\subsubsection{Resistência à tração na flexão}

$\mathrm{Na}$ Tabela 17 apresentam-se os resultados de resistência à tração, obtidos em ensaio de flexão com aplicação de carga nos terços do vão. Notam-se boas resistências obtidas, sendo que até mesmo os concretos com menores consumos superaram os concretos de referência. Para pisos industriais em geral especificam-se resistências aos 28 dias na ordem de 4,0 a 5,5 MPa e em pavimentos de rolagem de maior exigência, como aeroportos e avenidas, 5,5 a 6,0 MPa (MATTOS, 2004). A maioria dos concretos elaborados com baixo consumo de cimento atende a esta especificação mais exigente.

Ganhos de resistência da ordem de 10 a $20 \%$ foram observados dos 28 aos 63 dias para os cimentos CP III-40-RS. Não foram realizados ensaios em idade superior a 28 dias para o cimento CP V-ARI, porém observando os resultados para compressão em idade de 91 dias pode-se acreditar que na tração também é possível pequenos acréscimos mesmo para este cimento de endurecimento mais rápido.

Tabela 17 - Resistência à tração na flexão, em MPa, dos concretos estudados.

\begin{tabular}{ccccccc}
\hline \multirow{2}{*}{ Idades } & \multicolumn{7}{c}{ Traços } \\
\cline { 2 - 7 } & V280 & V200 & VR4 & III280 & III210 & IIIR4 \\
\hline 28 dias & 8,3 & 6,2 & 4,5 & 7,2 & 5,1 & 4,7 \\
\hline 63 dias & - & - & - & 7,9 & 6,1 & 5,7 \\
\hline
\end{tabular}

A ABNT NBR 6118:2003 apresenta equação para estimativa de resistência direta a tração em função da resistência à compressão:

$$
f_{c t}=0,3 f c^{2 / 3}
$$


Estima também a resistência à tração na flexão a partir da tração direta como sendo:

$$
f_{c t, f}=f_{c t} / 0,7
$$

$\mathrm{Na}$ Tabela 18 apresentam-se os valores de resistência à compressão aos 28 dias e a resistência à tração na flexão calculada conforme as equações da norma. Na última linha apresenta-se a relação entre o valor experimental obtido (ver Tabela 17) e a calculada pelas equações teóricas.

Tabela 18 - Comparação entre os valores de resistência à tração na flexão, obtidos aos 28 dias, e os previstos pela ABNT NBR 6118:2003 com base na resistência à compressão.

\begin{tabular}{ccccccc}
\hline & \multicolumn{7}{c}{ Traços } \\
\cline { 2 - 7 } & V280 & V200 & VR4 & III280 & III210 & IIIR4 \\
\hline $\mathrm{f}_{\mathrm{c}}(\mathrm{MPa})$ & 67,9 & 51,9 & 40,7 & 55,4 & 34,5 & 30,0 \\
\hline $\mathrm{f}_{\mathrm{ct}, \mathrm{f}(\text { teórico) }}(\mathrm{MPa})$ & 7,1 & 6,0 & 5,1 & 6,2 & 4,5 & 4,1 \\
\hline$\frac{\mathrm{f}_{\mathrm{ct}, \mathrm{f}(\text { experimental) }}}{\mathrm{f}_{\mathrm{ct} \text { ( } \mathrm{f} \text { (teórico) }}}$ & 1,16 & 1,04 & 0,88 & 1,15 & 1,12 & 1,14 \\
\hline
\end{tabular}

Nota-se que os resultados experimentais obtidos com os concretos de baixo consumo de cimento superam a previsão teórica, tendo, portanto, boa indicação para utilização em pisos. Estão, no entanto, ainda dentro do intervalo de variação admitido pela própria norma, que sugere valor característico superior 30 \% acima do valor médio.

\subsubsection{Módulo de elasticidade}

A avaliação do módulo de elasticidade é importante dada a sua relação com as deformações estruturais. Tanto as deformações imediatas como as de longo prazo tem relação com o módulo de elasticidade. A previsão de flechas e o planejamento de retirada de escoramentos dependem da evolução e das características elásticas do concreto.

Os resultados de módulo de elasticidade (Figura 47) seguem a tendência da resistência à compressão, com os concretos de baixo consumo apresentando valores superiores aos de referência. Os traços com baixo consumo de cimento apresentam módulo de elasticidade entre 50 e $60 \mathrm{GPa}$, enquanto que os de referência entre 30 e $40 \mathrm{GPa}$.

Além da maior resistência, que presume menor porosidade e zona de interface melhorada, o que aumenta o módulo de elasticidade, este é fortemente influenciado pelas características elásticas dos agregados. Nos concretos com baixo consumo de cimento temse maior proporção de agregados, o que acaba aumentando o módulo de elasticidade destes concretos. 


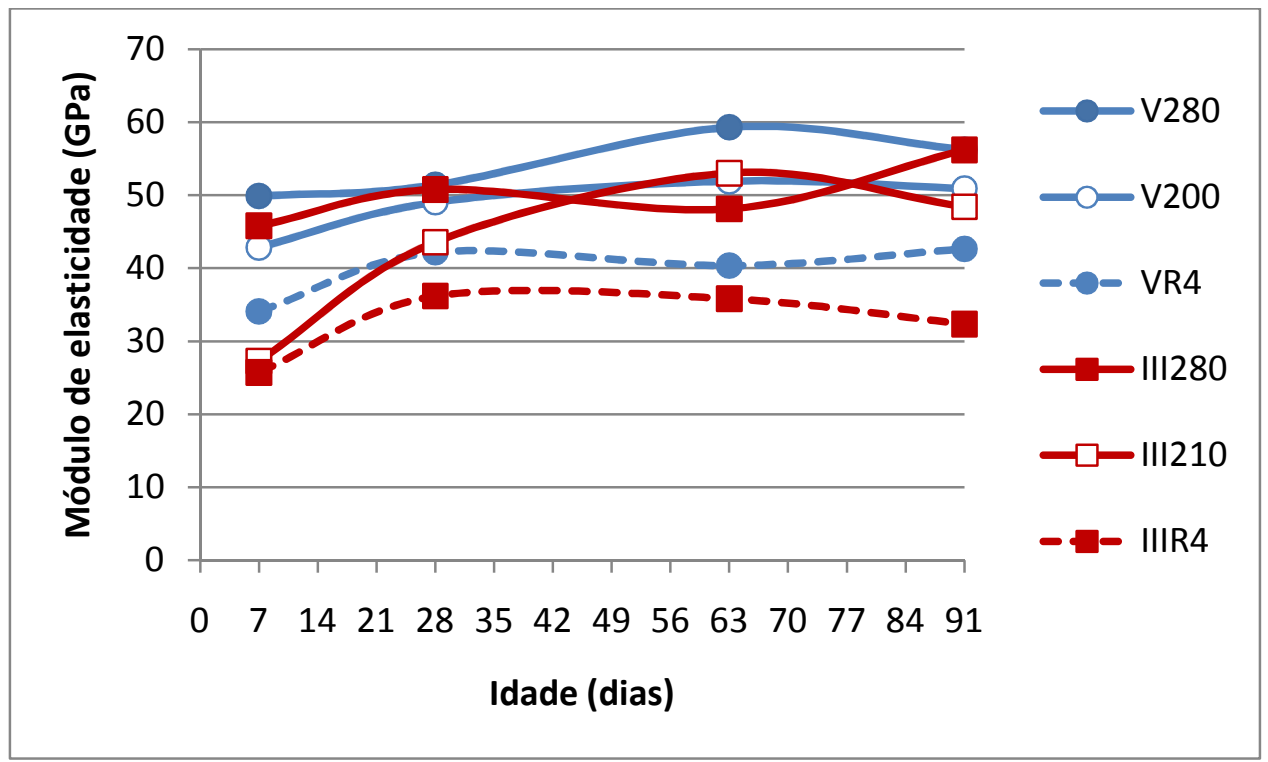

Figura 47 - Evolução do módulo de elasticidade com a idade dos concretos estudados

A ABNT NBR 6118:2003 apresenta uma equação para estimativa do módulo de elasticidade em função da resistência à compressão:

$$
E_{c}=5600 \sqrt{f_{c}}
$$

sendo que tanto $f_{c}$ como $E_{c}$ devem ser expressos em MPa.

$\mathrm{Na}$ Tabela 19 calculam-se a razão entre o módulo de elasticidade experimental obtido e a raiz da resistência à compressão, ambos na idade de 28 dias.

Tabela 19 - Comparação entre os valores de módulo de elasticidade obtido aos 28 dias e os previstos pela ABNT NBR 6118:2003 com base na resistência à compressão

\begin{tabular}{ccccccc}
\hline & \multicolumn{6}{c}{ Traços } \\
\cline { 2 - 7 } & V280 & V200 & VR4 & III280 & III210 & IIIR4 \\
\hline $\mathrm{f}_{\mathrm{c}}(\mathrm{MPa})$ & 67,9 & 51,9 & 40,7 & 55,4 & 34,5 & 30 \\
\hline $\mathrm{E}_{\mathrm{c}}(\mathrm{MPa})$ & 51.413 & 49.021 & 42.174 & 50.780 & 43.546 & 36.184 \\
\hline$\frac{E_{c}}{\sqrt{f_{c}}}$ & 6.241 & 6.806 & 6.609 & 6.822 & 7.409 & 6.603 \\
\hline
\end{tabular}

A ABNT NBR 6118:2003 prevê uma razão de $E_{c} / \sqrt{f_{c}}$ igual a 5.600 , valor baixo se comparado aos resultados obtidos. Seguindo a recomendação do IBRACON (2007), que sugere a correção deste valor para concretos com agregados basálticos, pela multiplicação por um coeficiente de 1,1 a 1,2, chega-se a valores entre 6.160 a 6.720 , os quais estão bem de acordo com os resultados experimentais obtidos. 


\subsubsection{Indicadores de consumo}

Conforme abordado no item 2.3 (Indicadores de baixo consumo de cimento) vários indicadores para avaliar o desempenho do cimento consumido podem ser empregados. Neste trabalho será utilizada a resistência à compressão como parâmetro principal de avaliação de desempenho. Este parâmetro é avaliado em face do consumo de cimento, consumo total de materiais cimentícios, consumo de clínquer e emissão aproximada de $\mathrm{CO}_{2}$. $\mathrm{Na}$ Tabela 20 estão resumidos os consumos para volume de $1 \mathrm{~m}^{3}$ dos diversos traços. $\mathrm{O}$ teor de clínquer é de $95 \%$ no cimento CP V-ARI e $49 \%$ no cimento CP III-40-RS. A emissão de $\mathrm{CO}_{2}$ foi estimada em $0,86 \mathrm{~kg}$ de $\mathrm{CO}_{2}$ por $\mathrm{kg}$ de clínquer.

Tabela 20 - Consumos de cimento, material cimentício, clínquer e emissão de $\mathrm{CO}_{2}$ para os seis traços analisados $\left(\mathrm{kg} / \mathrm{m}^{3}\right)$

\begin{tabular}{ccccccc}
\hline \multirow{2}{*}{ Consumos } & \multicolumn{7}{c}{ Traços } \\
\cline { 2 - 7 } & V280 & V200 & VR4 & III280 & III210 & IIIR4 \\
\hline Cimento & 279 & 199 & 426 & 276 & 208 & 437 \\
\hline Cimentícios & 302 & 216 & 426 & 300 & 226 & 437 \\
\hline Clínquer & 265 & 189 & 405 & 135 & 102 & 214 \\
\hline $\mathrm{CO}_{2}$ & 228 & 163 & 348 & 116 & 88 & 184 \\
\hline
\end{tabular}

A partir destes consumos, e utilizando a resistência à compressão aos 28 dias como parâmetro de desempenho, pode-se calcular os consumos relativos (Tabela 21).

Tabela 21 - Consumos de cimento, material cimentício, clínquer e emissão de $\mathrm{CO}_{2}$ para os seis traços analisados relativos à resistência à compressão aos 28 dias $\left(\mathrm{kg} \cdot \mathrm{m}^{-3} \cdot \mathrm{MPa}^{-1}\right)$

\begin{tabular}{|c|c|c|c|c|c|c|}
\hline \multirow{2}{*}{ Consumos } & \multicolumn{6}{|c|}{ Traços } \\
\hline & V280 & V200 & VR4 & III280 & III210 & IIIR4 \\
\hline Cimento & 4,1 & 3,8 & 10,5 & 5,0 & 6,0 & 14,6 \\
\hline Cimentícios & 4,5 & 4,2 & 10,5 & 5,4 & 6,5 & 14,6 \\
\hline Clínquer & 3,9 & 3,6 & 9,9 & 2,4 & 3,0 & 7,1 \\
\hline $\mathrm{CO}_{2}$ & 3,4 & 3,1 & 8,5 & 2,1 & 2,5 & 6,1 \\
\hline
\end{tabular}

Nota-se em geral que os consumos relativos de cimento aos 28 dias ficaram em torno de $4 \mathrm{~kg} \cdot \mathrm{m}^{-3} \cdot \mathrm{MPa}^{-1}$ para os concretos com CP V-ARI e entre 5 e $6 \mathrm{~kg} \cdot \mathrm{m}^{-3} \cdot \mathrm{MPa}^{-1}$ para os concretos com cimento CP III-40-RS. Comparando com os resultados coletados por Damineli et al. (2010), que consideram o total de materiais cimentícios, obtém-se a Figura 48. Nota-se o bom resultado obtido, principalmente dos traços com CP V-ARI, estando os resultados dos concretos de baixo consumo abaixo do limite inferior da grande maioria dos resultados coletadas. Já os concretos de referência ficaram contidos dentro da grande nuvem média. 

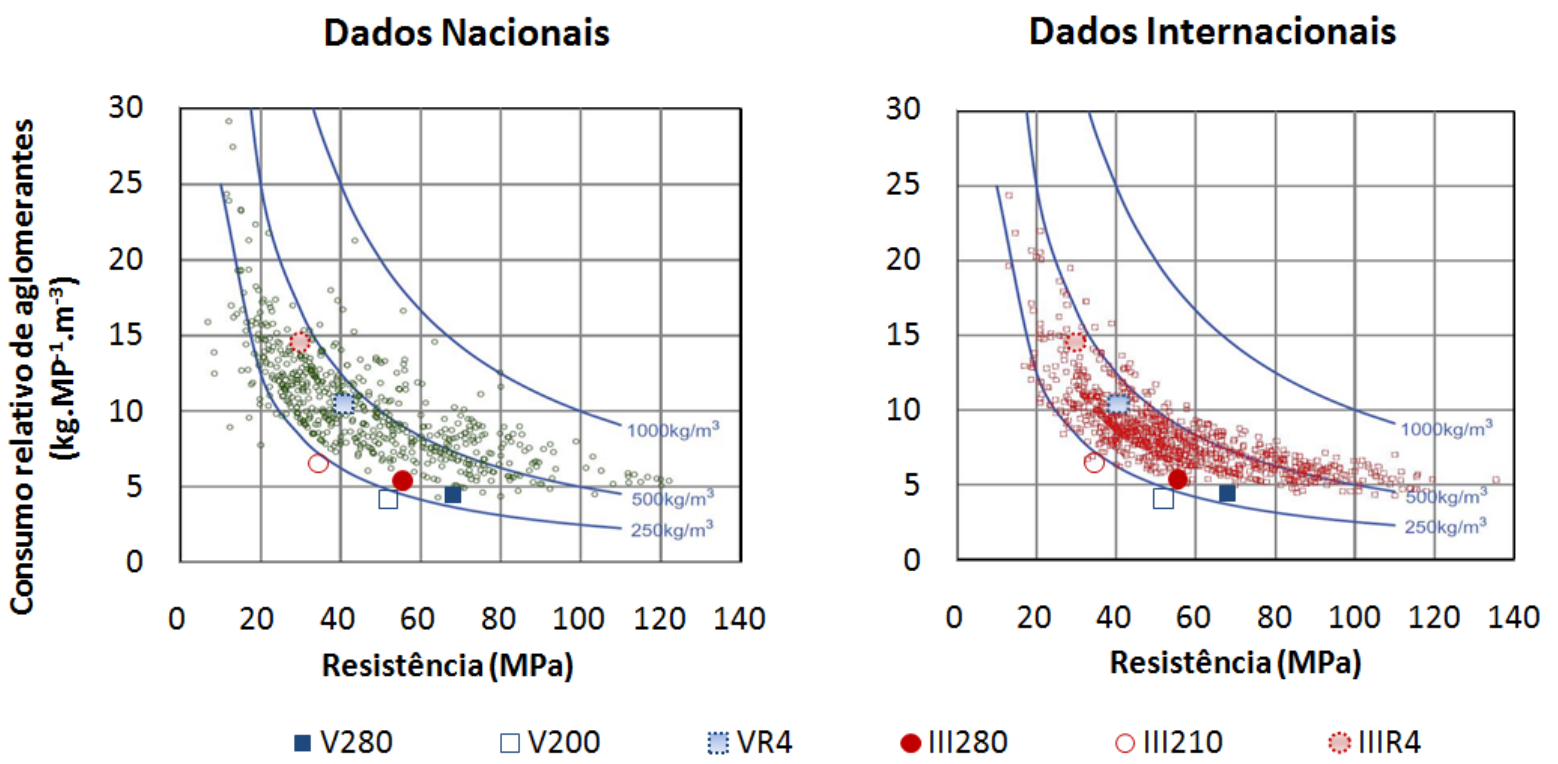

Figura 48 - Relação entre consumo de aglomerantes e resistência à compressão aos 28 dias.

Fonte: adaptada de Damineli et al. (2010), incluindo os resultados dos concretos desenvolvidos neste trabalho.

Avaliando a emissão de $\mathrm{CO}_{2}$, os traços com cimento CP III-40-RS mostraram ótimo desempenho, com valores abaixo de $3 \mathrm{~kg} \cdot \mathrm{m}^{-3} \cdot \mathrm{MPa}^{-1}$.

Fazendo uma análise de consumo relativo, utilizando a resistência à tração na flexão como parâmetro de desempenho, chega-se a valores de consumo de cimento entre $30 \mathrm{e}$ $40 \mathrm{~kg} \cdot \mathrm{m}^{-3} \cdot \mathrm{MPa}^{-1}$ para os concretos com baixo consumo de cimento e 90 a $100 \mathrm{~kg} \cdot \mathrm{m}^{-3} \cdot \mathrm{MPa}^{-1}$ para os concretos de referência. Novamente nota-se o bom desempenho dos traços executados. O mesmo pode ser concluído em análise baseada no módulo de elasticidade, obtendo-se valores de módulo de elasticidade superiores aos concretos de referência mesmo com menores consumos de cimento.

De modo geral os concretos apresentaram ótimo desempenho de consumo, tanto em termos de consumo de material cimentício como em termos de emissão de $\mathrm{CO}_{2}$, além de consumo total de cimento reduzido.

\subsection{Ensaios de durabilidade do concreto endurecido}

Conforme apresentado nas seções anteriores, os concretos obtidos comprovadamente podem ser considerados de baixo consumo de cimento. A avaliação destes concretos, quanto a diversos aspectos de durabilidade, é apresentada a seguir. 


\subsubsection{Absorção de água por imersão}

O ensaio de absorção de água por imersão mede o volume de vazios abertos, dando uma ideia da porosidade do concreto.

Conforme já explicado na seção 4.5.1, o ensaio realizado com idade de 28 dias de cura do concreto foi realizado a temperatura de secagem de apenas $75{ }^{\circ} \mathrm{C}$. Devido à baixa temperatura de secagem os resultados não podem ser comparados com resultados de ensaios realizados na temperatura normatizada de $105{ }^{\circ} \mathrm{C}$. Os baixos resultados de absorção obtidos com os concretos de baixo consumo de cimento neste ensaio, em torno de $1,5 \%$, levaram à análise de todo o processo de ensaio. Identificou-se inicialmente 0 problema na temperatura de regulagem da estufa. Além disso, passou-se a questionar a efetividade da secagem. Temperaturas mais altas possibilitam melhor secagem, porém, podem não conduzir a valores reais de porosidade uma vez que acima de $80{ }^{\circ} \mathrm{C}$ já se tem eliminação de água combinada dos produtos de hidratação e também maior atividade de hidratação de compostos ainda não hidratados, principalmente pozolânicos (CHEYREZY, VINCENT E FROUIN, 1995). Deve-se considerar ainda que em concretos com baixa porosidade e alto empacotamento a saída de água é lenta devido à finura e tortuosidade da rede capilar.

Investigou-se então a efetividade da secagem na temperatura padronizada de $105^{\circ} \mathrm{C}$. Inicialmente avaliou-se a perda de massa na secagem por período até quatro vezes superior ao recomendado pela norma. A cada período de 3 dias foram feitas medições de massa em corpos de prova cilíndricos de $10 \mathrm{~cm}$ × $20 \mathrm{~cm}$ mantidos em estufa ventilada a $105+/-5^{\circ} \mathrm{C}$, fazendo-se diariamente rodízio nas posições de maneira a reduzir variações devido a diferenças de temperatura localizados. Os resultados (Figura 49) mostram que, embora boa parte da perda de água realmente ocorre nos três primeiros dias, há ainda perdas posteriores. Pela inclinação das curvas pode-se inclusive verificar que há tendência de perda de água após 12 dias de secagem nos concretos de baixo consumo de cimento, enquanto que os concretos de referência estabilizaram aos nove dias de secagem. Esta observação indica que os concretos de baixo consumo de cimento, além de terem menor porosidade total, também possuem poros mais finos e/ou tortuosos que dificultam a saída da água. 


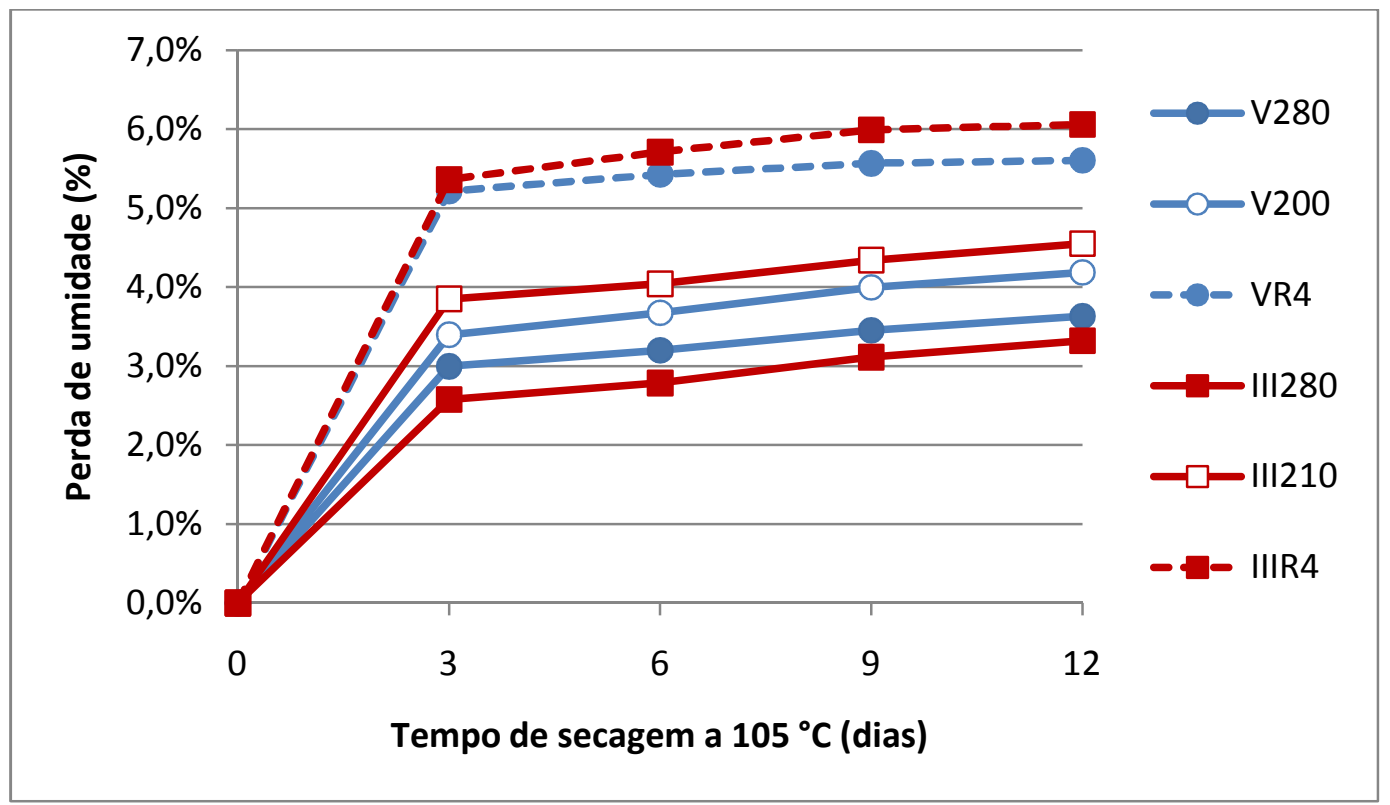

Figura 49 - Ensaio de secagem por até 12 dias para avaliação da dificuldade de eliminação da água em ensaios de absorção

A partir dos resultados pode-se supor que boa parte da água perdida ao longo do ensaio realmente ainda é água livre e não água combinada, pois se não fosse assim, os concretos de referência, que possuem muito mais material hidratado que os de baixo consumo de cimento, deveriam mostrar perda mais acentuada que os de baixo consumo de cimento. Para reforçar esta conclusão propôs-se então um ensaio adicional que pudesse de maneira qualitativa mostrar que ainda existe água livre no centro dos corpos de prova, mesmo após a secagem. Para isto os corpos de prova foram rompidos por compressão diametral e aplicou-se sobre a região recém-fraturada um filme impregnado de sílica-gel com indicador de umidade. O filme é pressionado sobre a superfície e o conjunto é envolto com filme PVC para evitar a entrada de umidade do ambiente. Em intervalos de tempo o filme de sílica-gel é fotografado. O aparecimento de manchas de tonalidade rosa indica regiões com presença de água livre, enquanto que as porções azuis indicam regiões secas. O procedimento foi considerado com precisão adequada, pois se pôde notar que regiões onde havia fragmento de brita, imerso numa região com umidade, manteve-se a tonalidade azul (seca) no local da brita.

$\mathrm{Na}$ Figura 50 mostram-se três fotos, sendo duas de concreto convencional, com $\mathrm{a} / \mathrm{c}=0,55$ (esquerda) e $\mathrm{a} / \mathrm{c}=0,45$ (centro), e uma de concreto de baixo consumo de cimento, do traço III280 (direita). As fotos foram obtidas após secagem a $105{ }^{\circ} \mathrm{C}$ por três dias. No concreto convencional com $\mathrm{a} / \mathrm{c}=0,55$ não se percebe nenhum sinal de umidade. No concreto com $a / c=0,45$ já é possível ver pequena região com umidade. Já no concreto 
de baixo consumo de cimento é possível notar que boa parte da região interna ainda apresenta umidade.
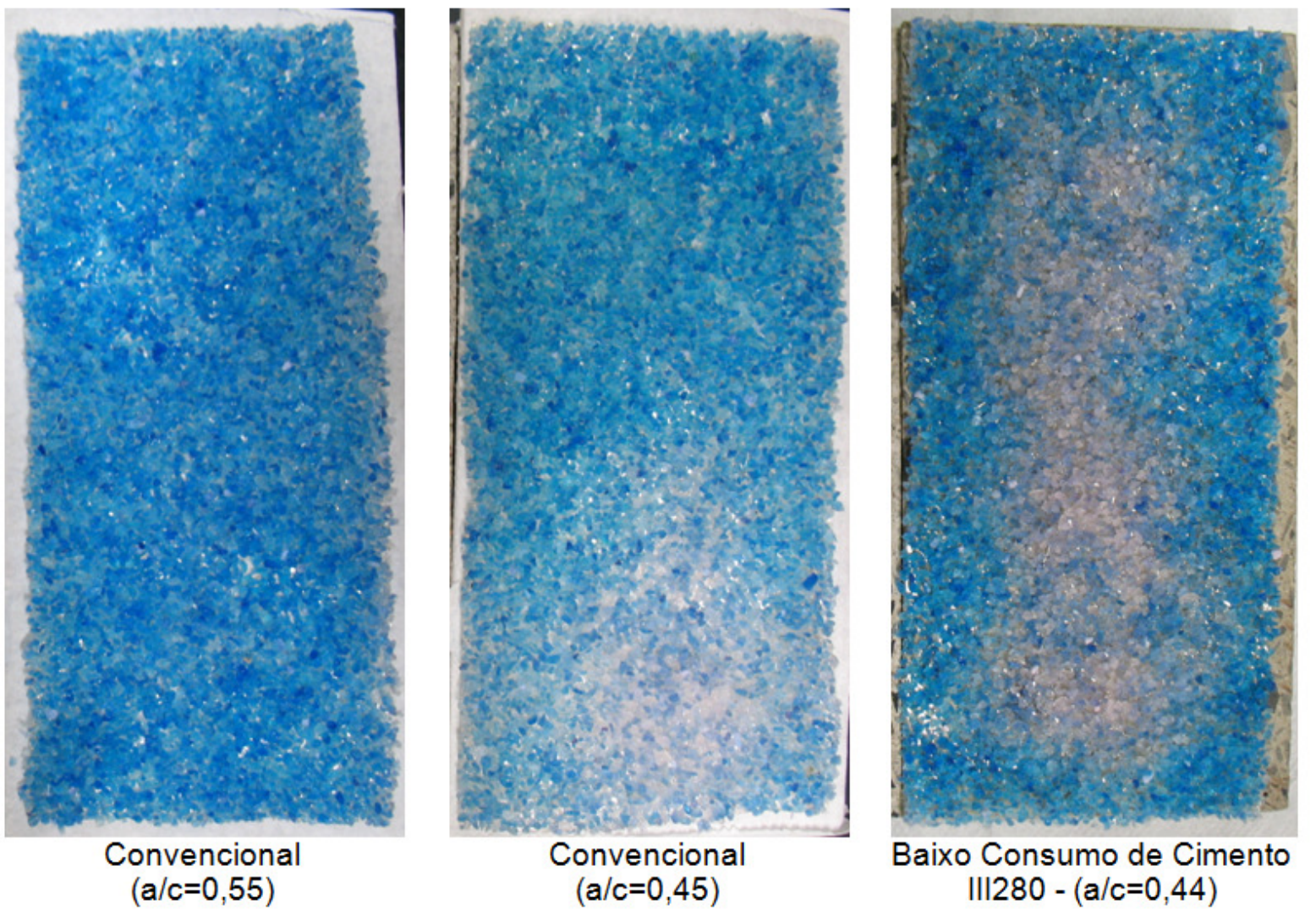

Figura 50 - Avaliação de umidade interna, com auxílio de filme de sílica-gel, após 3 dias de secagem do concreto a $105{ }^{\circ} \mathrm{C}$.

O mesmo procedimento foi aplicado para identificar a posição do nível de penetração de água por capilaridade, cujos resultados são mostrados na seção 5.5.2. Nestas fotos também podem ser visualizadas manchas no centro dos corpos de prova de todos os traços de baixo consumo de cimento, acima da linha de penetração de água por capilaridade. Isto mostra que não foi eliminada toda a água durante o processo de secagem, mesmo com tempos de secagem de 12 dias.

Estes indícios complementam as observações anteriores e levam a concluir que ensaios de absorção de água realizados com o procedimento da ABNT NBR 9778:2005 levam a resultados de porosidade menores que os reais para concretos de porosidade refinada. A origem desta norma está em procedimentos originalmente aplicados a concretos convencionais de baixa resistência. O uso deste procedimento para concretos de mais elevado desempenho parece não ser completamente aplicável, sendo nestes casos a real porosidade maior que a determinada. $\mathrm{Na}$ falta de alternativas, os resultados de absorção e 
índice de vazios obtidos desta forma devem ser considerados apenas com finalidade comparativa e não como indicação da real porosidade do concreto.

Para a idade de 63 dias foi realizado então o ensaio de absorção por imersão com os dois tempos de secagem. Na Figura 51 mostram-se os resultados. Nota-se mais uma vez que utilizando menor tempo de secagem ocorre subavaliação da porosidade pelo ensaio de absorção de água.

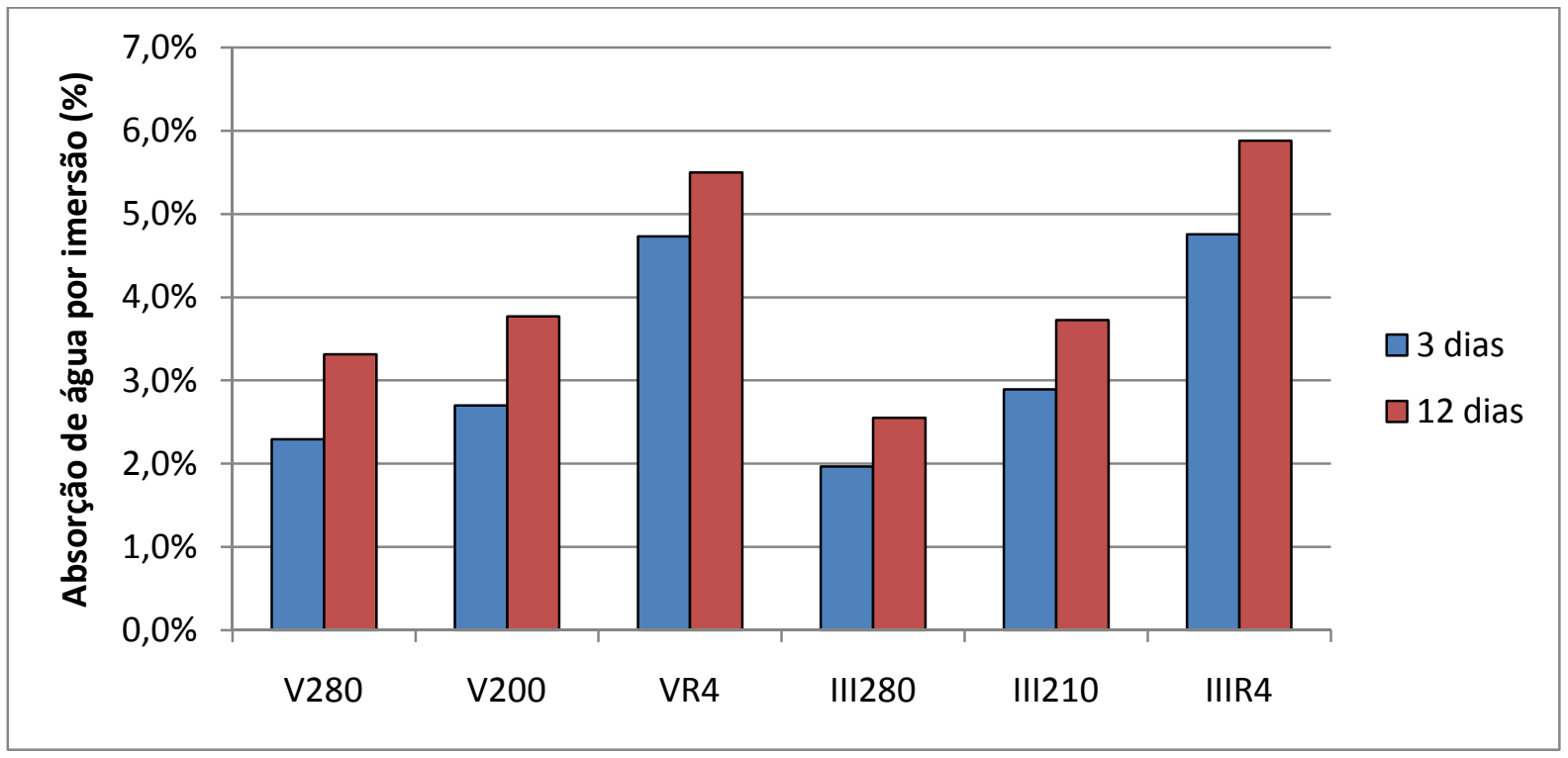

Figura 51 - Absorção de água por imersão com tempos de secagem de 3 e 12 dias a $105^{\circ} \mathrm{C}$ e cura do concreto por 63 dias.

Nota-se absorção de água bem inferior nos traços com baixo consumo de cimento. Todos estes apresentaram com 3 dias de secagem absorção de água por imersão inferior a $3 \%$, podendo ser enquadrado nas melhores classificações segundo o critério do $\mathrm{CEB}^{38}$ e de Helene $^{39}$. Já os concretos de referência apresentaram valores em torno de $5 \%$, estando no limite entre qualidade média e pobre do CEB e na classificação de qualidade média de Helene. Os concretos de baixo consumo com $280 \mathrm{~kg} / \mathrm{m}^{3}$ de cimento possuem absorção ligeiramente inferior aos de $200 / 210 \mathrm{~kg} / \mathrm{m}^{3}$, o que deve ser em virtude da maior porosidade da pasta dos concretos de menor consumo total de cimento. Estes têm relação água/aglomerantes em torno de 0,60 enquanto que os de $280 \mathrm{~kg} / \mathrm{m}^{3}$ têm relação a/agl em torno de 0,44 . Os concretos de referência, que possuem relação a/agl nesta mesma faixa de 0,44 não tiveram o mesmo bom desempenho, o que mostra o ganho que se obtém graças ao melhor empacotamento dos agregados (caminhos de percolação mais longos e tortuosos), de dispersão das partículas (refinamento dos poros) e dos efeitos físicos e químicos devido às adições minerais (refinamento dos poros). 
Não se verificou diferença considerável entre os tipos diferentes de cimento, possuindo os traços equivalentes resultados próximos.

Conclusões semelhantes são obtidas ao analisar o índice de vazios (Figura 52). Comparando com o critério de Andrade Perdrix (1992) pode-se dizer que os concretos de baixo consumo de cimento são de boa qualidade, estando sensivelmente abaixo do limite de $10 \%$, enquanto que os de referência são classificados apenas como sendo de média qualidade (no intervalo de 10 a $15 \%$ ).

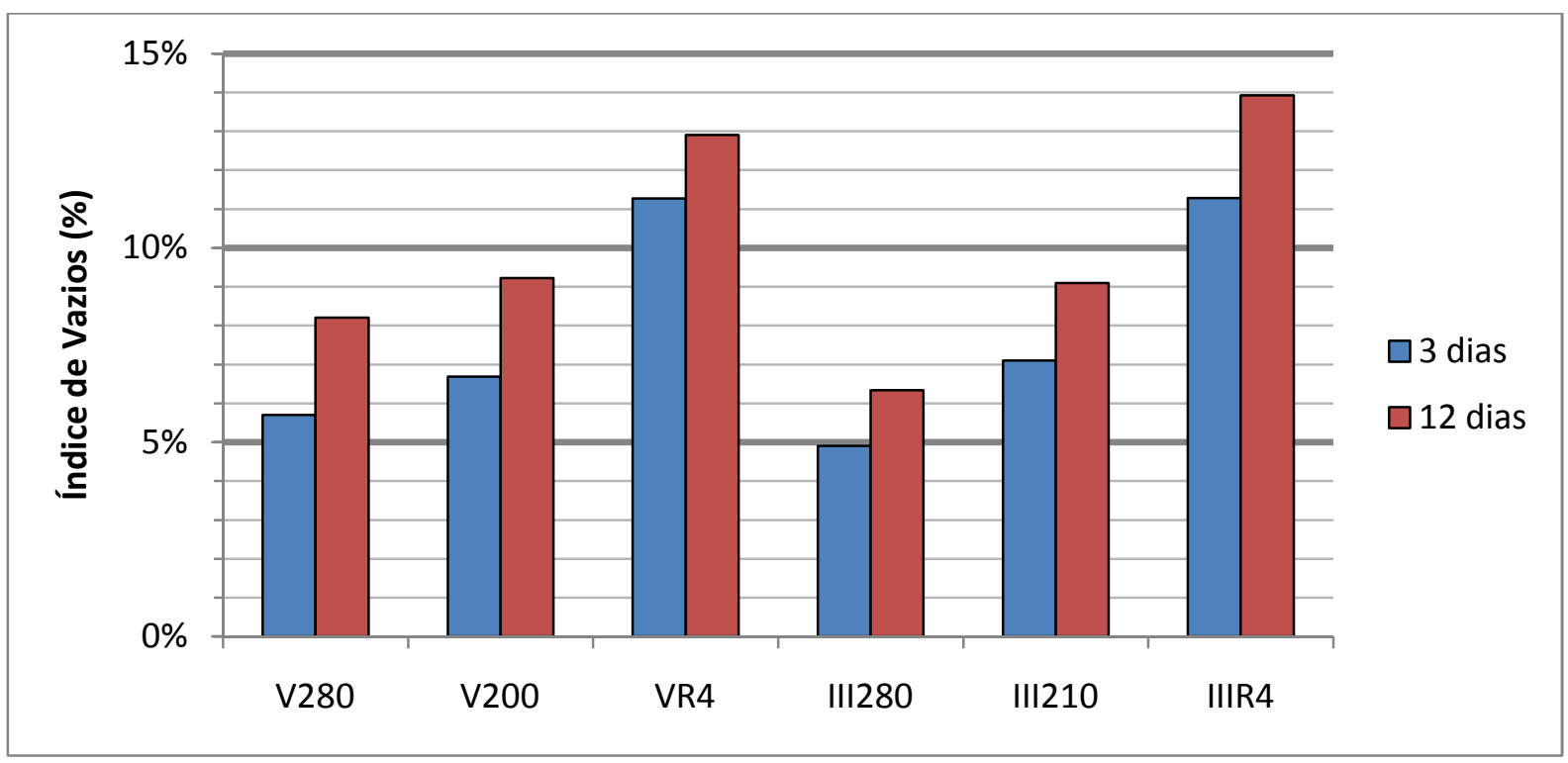

Figura 52 - Índice de vazios por imersão com tempos de secagem de 3 e 12 dias a $105{ }^{\circ} \mathrm{C}$ e cura do concreto por 63 dias.

\subsubsection{Absorção de água por capilaridade}

O ensaio de absorção de água por capilaridade visa avaliar a facilidade com que o concreto absorve água por este mecanismo de transporte. A absorção capilar ocorre rotineiramente em estruturas de concreto, tanto naqueles elementos estruturais em contato com solo úmido ou parcialmente imersos em água, como naqueles onde ocorrem ciclos de secagem e molhagem, devido à chuva, por exemplo.

O ensaio de absorção por capilaridade foi realizado paralelamente ao de absorção por imersão, sendo toda a análise de presença de umidade interna, após a secagem conforme a recomendação normativa, válida também para este ensaio. A existência de núcleo interno com umidade pode reduzir o volume de água absorvido por capilaridade, caso a frente de penetração por capilaridade avance até este núcleo. 
Para verificar esta questão aplicou-se também o procedimento de detecção de umidade interna com filme de sílica-gel. O filme indica não somente a existência de umidade interna como também delimita com clareza o nível da frente de capilaridade, o que por vezes é de difícil observação visual, principalmente em concretos de baixa porosidade.

$\mathrm{Na}$ Figura 53 mostram-se as fotos dos corpos de prova que foram secos durante 3 dias a $105{ }^{\circ} \mathrm{C}$, conforme previsto pela NBR 9779:2005. Nota-se em todos os concretos de baixo consumo de cimento uma região central com tonalidade rosa irregular, indicando núcleo que não foi seco completamente. No concreto de referência com CP V-ARI (VR4) não foi possível distinguir com clareza se houve também centro não seco completamente, pois o nível da frente de capilaridade subiu muito. Já no traço de referência com CP III-40RS pode-se ver uma região central mais clara.

Na Figura 54 é mostrado o resultado equivalente à secagem durante período de 12 dias. Nos concretos de baixo consumo de cimento ainda é possível notar, em intensidades diferentes, uma mancha interna indicando a presença de umidade. Já nos concretos de referência não se observa tal umidade. Este resultado mostra que, mesmo com secagem intensa durante longo período, não foi possível eliminar a umidade interna dos concretos de baixo consumo de cimento. Isto indica a presença de rede porosa de difícil acesso, possivelmente desconectada, o que é bom indicador de durabilidade.

V280
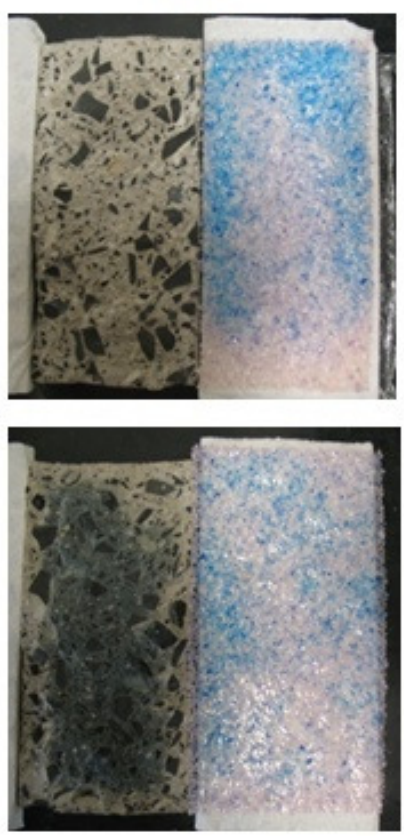

III280
V200
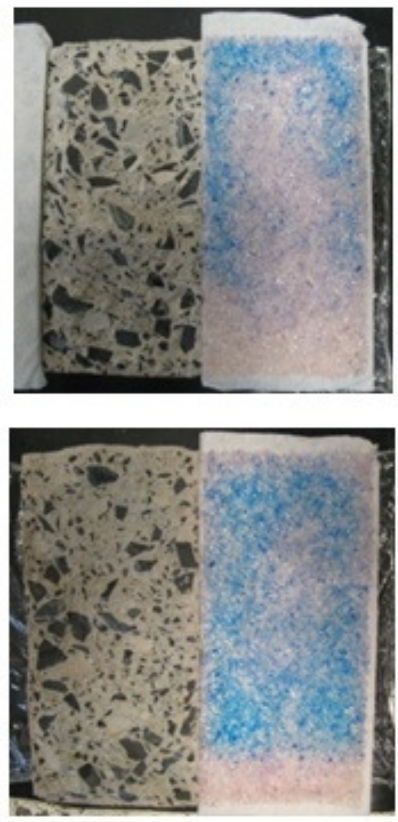

III210
VR4
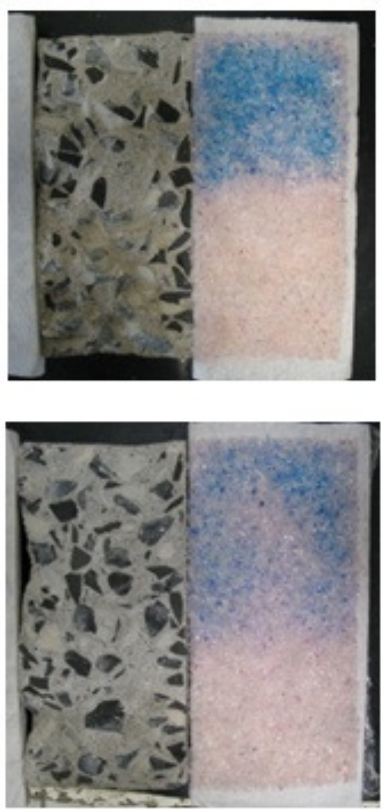

IIIR4

Figura 53 - Avaliação de nível da frente de capilaridade e presença de umidade interna antes do ensaio, para tempo de secagem de 3 dias. 


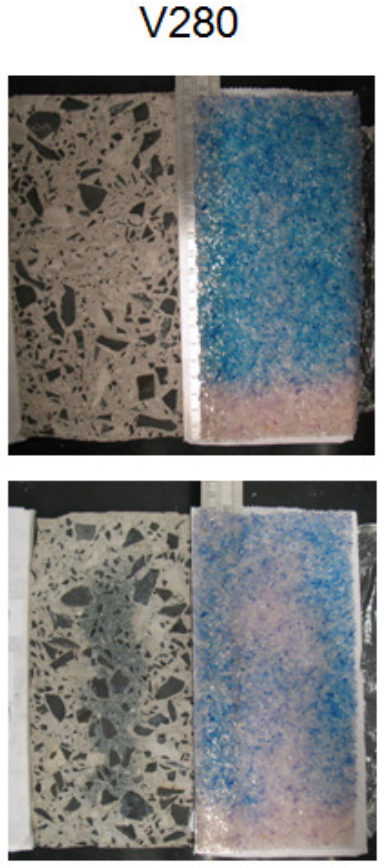

III280

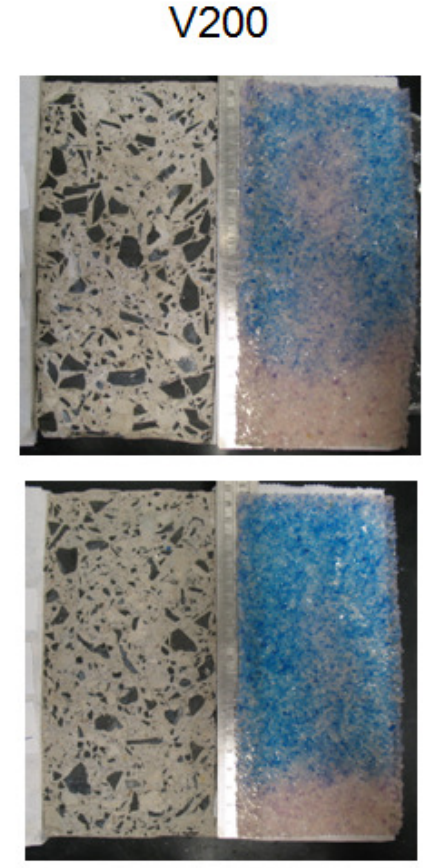

III210
VR4
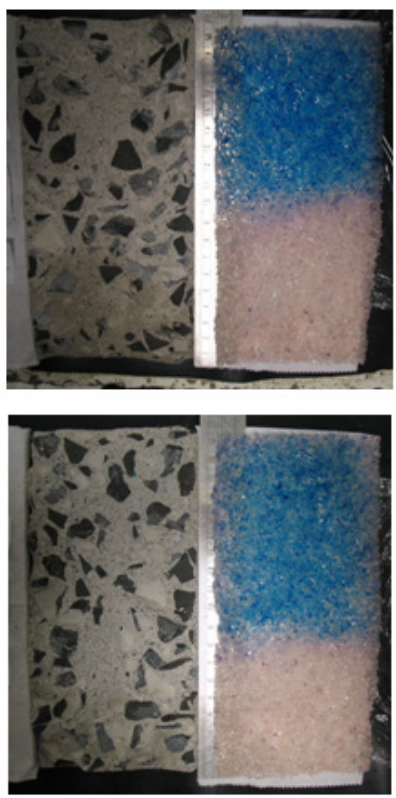

IIIR4

Figura 54 - Avaliação de nível da frente de capilaridade e presença de umidade interna antes do ensaio, para tempo de secagem de 12 dias.

Em virtude da dificuldade de secagem e da menor temperatura utilizada na secagem para a idade de 28 dias, não serão apresentados estes resultados, citando apenas que tanto a absorção capilar quanto a altura nos concretos de referência foram bem superiores aos dos concretos de baixo consumo de cimento.

$\mathrm{Na}$ idade de cura de 63 dias também se comparou a absorção de água com os dois tempos de secagem, 3 e 12 dias. A partir dos volumes de água absorvidos pelos corpos de prova ao longo do ensaio pode-se construir uma curva de absorção capilar que relaciona a absorção (volume de água que ingressa pela seção transversal do corpo de prova, expresso em $\mathrm{g} / \mathrm{cm}^{2}$ ) e a raiz do tempo (expresso em $\mathrm{h}^{1 / 2}$ ). Hall ${ }^{53}$ (1989) apud Nepomuceno (2005) mostrou que tal relação pode ser aproximada por uma reta cujo coeficiente angular se denomina de coeficiente de absorção capilar. Na Figura 55 são indicados estes coeficientes de absorção capilar para os seis traços em estudo.

${ }^{53}$ HALL, C. Watter sorptivity of mortars and concretes: a review. Magazine of Concrete Research, London, v. 41, n. 147 , p. 51-61, 1989. 


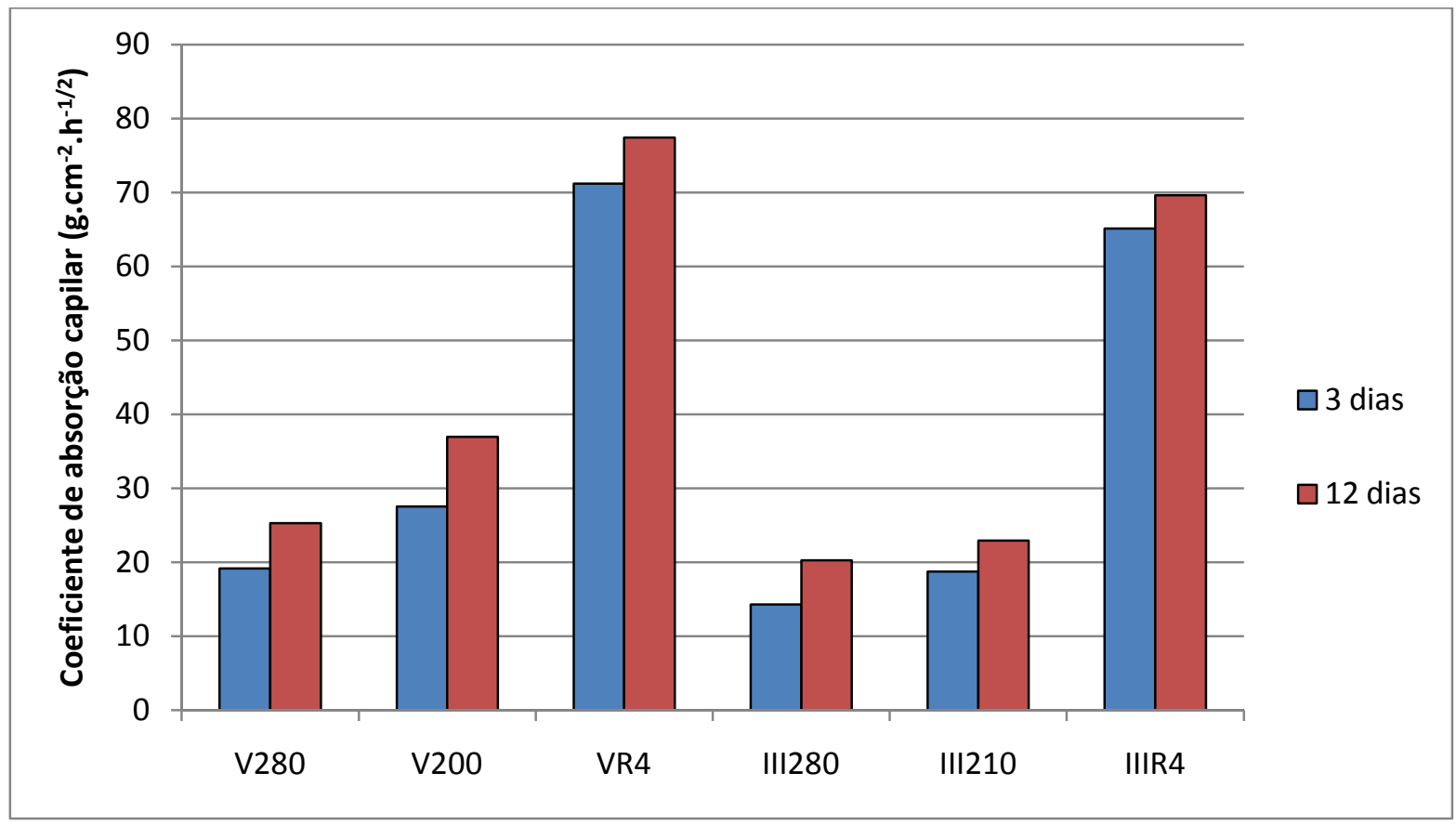

Figura 55 - Coeficiente de absorção capilar com tempos de secagem de 3 e 12 dias a $105{ }^{\circ} \mathrm{C}$ e cura do concreto por 63 dias.

Novamente nota-se que o tempo de secagem influencia os resultados. Os resultados também mostram a alta taxa de absorção capilar dos concretos de referência quando comparados com os concretos de baixo consumo de cimento. O uso de cimento CP III-40$\mathrm{RS}$ resultou em menores absorções.

A altura da frente de capilaridade foi determinada na face externa do corpo de prova, onde pode ser realizado o acompanhamento do avanço ao longo do tempo por meio da marcação do limite úmido, como exemplificado na Figura 56. Os dois concretos se referem aos traços IIIR4 e III280, sendo um bom exemplo da diminuição da altura de avanço da capilaridade nos traços de baixo consumo de cimento.

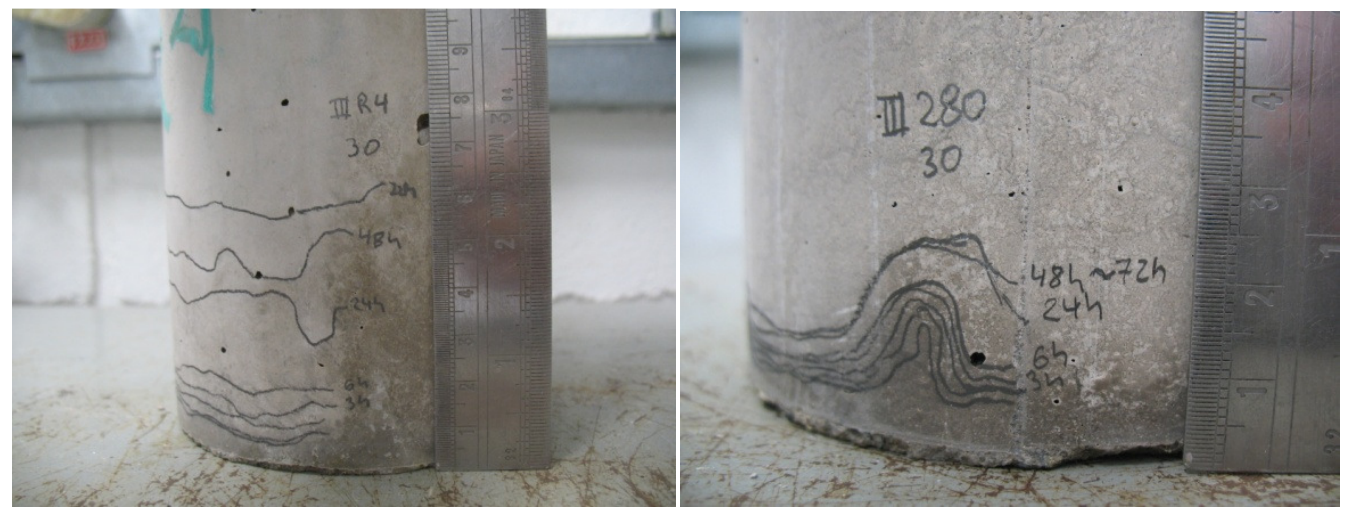

Figura 56 - Marcação externa da frente de avanço da capilaridade 
Também se determinou a altura e distribuição interna da água absorvida por capilaridade por meio do filme de sílica-gel, conforme Figura 53 e Figura 54. Os resultados são apresentados na Tabela 22.

Tabela 22 - Altura $(\mathrm{cm})$ da frente de avanço da capilaridade para tempos de secagem de 3 e 12 dias.

\begin{tabular}{cccccccc}
\hline Posição & Tempo de & \multicolumn{7}{c}{ Traços } \\
\cline { 2 - 8 } medida & secagem & V280 & V200 & VR4 & III280 & III210 & IIIR4 \\
\hline Nível & 3 dias & 2,7 & 4,5 & 8,0 & 1,5 & 1,8 & 6,0 \\
\cline { 2 - 8 } externo & 12 dias & 2,6 & 4,2 & 7,7 & 1,5 & 1,5 & 6,0 \\
\hline Nível & 3 dias & 2,5 & 3,2 & 10,5 & 2,0 & 2,3 & 7,5 \\
\cline { 2 - 8 } interno & 12 dias & 3,0 & 4,0 & 9,0 & 2,0 & 2,5 & 7,0 \\
\hline
\end{tabular}

Há boa correspondência entre as medidas internas e externas. As diferenças observadas devem-se às variações do nível da frente de avanço, que dificilmente é perfeitamente nivelada, como pode ser visto na Figura 53 e Figura 54. Isto ocorre principalmente devido à presença de agregados graúdos ou vazios que alteram o avanço na sua vizinhança. Na Figura 56 isto é ilustrado pela tortuosidade da marcação externa. A diferença de tempos de secagem não pode ser avaliada em termos de nível de avanço da capilaridade. Externamente não há diferença de secagem, pois as camadas superficiais do concreto secam facilmente. Internamente a avaliação com filme de sílica-gel fica prejudicada, pois há sobreposição da umidade de capilaridade com a umidade já presente. Considera-se que os valores obtidos, principalmente os próximos à superfície, são bons indicativos do potencial de subida de água por capilaridade em concretos secos.

Os níveis de avanço evidenciam mais uma vez a melhoria obtida nos traços com baixo consumo de cimento em relação aos de referência. Em média as alturas são inferiores a $30 \%$ da altura dos concretos de referência. Mesmo com 3 dias de contato com a água os concretos de baixo consumo de cimento com cimento CP III-40-RS não permitiram a entrada da água em profundidade equivalente ao cobrimento de armadura para concretos de vigas e pilares em ambiente de agressividade Nível I conforme ABNT NBR 6118:2003 $(2,5 \mathrm{~cm})$. Umedecimento esporádico, como o provocado por chuva, dificilmente causará penetração de água até a posição da armadura nos concretos de baixo consumo, o que é altamente positivo em termos de durabilidade.

A alta absorção obtida nos concretos de referência pode ser atribuída ao fato de se ter presença de grande porção de pasta de cimento com poros capilares bastante finos, devido ao fator água/cimento já bem reduzido. Este fator, no entanto, não foi suficiente para desconectar os poros que, pela pequena dimensão, levam a alta pressão capilar. Os concretos de baixo consumo possuem quantidade de pasta bem inferior e presença de 
grande taxa de agregados, graças ao alto empacotamento, aumentando em muito a sinuosidade do caminho da água. Com isto aumenta também a chance de haver interrupção dos capilares, fato facilitado pelo uso de alto teor de dispersante e a presença de adições minerais (sílica ativa e metacaulinita em todos os traços de baixo consumo de cimento, e adicionalmente escória de alto forno nos traços com cimento CP III-40-RS).

\subsubsection{Abrasão}

O ensaio de abrasão visa determinar a resistência superficial do concreto a desgaste decorrente de atrito físico. Na Figura 57 estão expressos os resultados de desgaste para percurso de 500 e 1000 m, executado segundo os critérios da ABNT NBR 12042:1992, além da classificação da ABNT 11801:1992, destinada a argamassas de alta resistência mecânica para pisos.

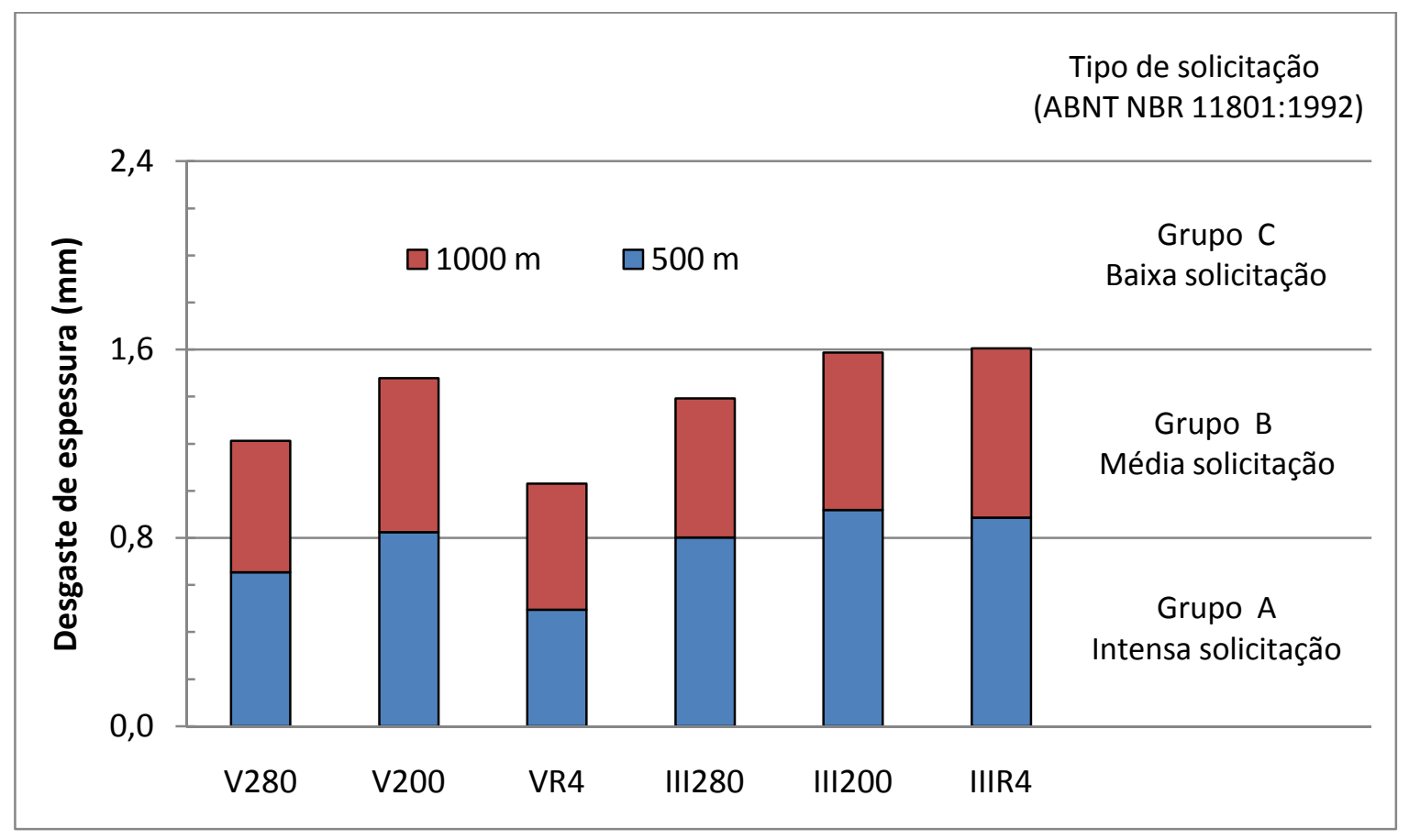

Figura 57 - Abrasão para percurso de $500 \mathrm{~m}$ e $1000 \mathrm{~m}$ e classificação de pisos quanto à solicitação.

Os resultados mostram que todos os concretos alcançaram classificação para o Grupo B, sendo adequados para solicitações médias (arraste e rolar de cargas médias, tráfego de veículos de rodas rígidas, tráfego intenso de pedestre e impacto de pequena intensidade). Baseado na revisão de literatura apresentada na seção 3.7, que analisou diversas experiências realizadas no Brasil segundo os critérios das normas citadas, pode-se considerar que o desempenho foi muito bom. Desgastes inferiores a $0,80 \mathrm{~mm}$ são muito 
difíceis de serem obtidos, dado o grau de agressão que o ensaio representa. Nos trabalhos relatados apenas traços especiais com endurecedores à base de agregados metálicos ou especiais conseguiram alcançar as exigências do Grupo A.

Quanto ao desempenho do tipo de cimento, aparentemente há melhor desempenho dos concretos executados com CP V-ARI. Estes concretos obtiveram também melhores resistências à compressão. Pela Figura 58 nota-se que, com exceção do traço VR4, os desgastes de abrasão têm razoável correspondência com a resistência à compressão, o que concorda com o observado por diversos estudos. Pode-se dizer que os concretos de baixo consumo obedecem a esta regra geral, existindo relação direta entre desgaste e resistência. Obtendo-se altas resistências à compressão com estes concretos será obtido bom desempenho a desgaste superficial, adequado para a maioria das situações comuns. Condições de desgaste especial devem ser avaliadas e o uso de agregados especiais pode ser indicado, de modo a aumentar o desempenho frente à abrasão.

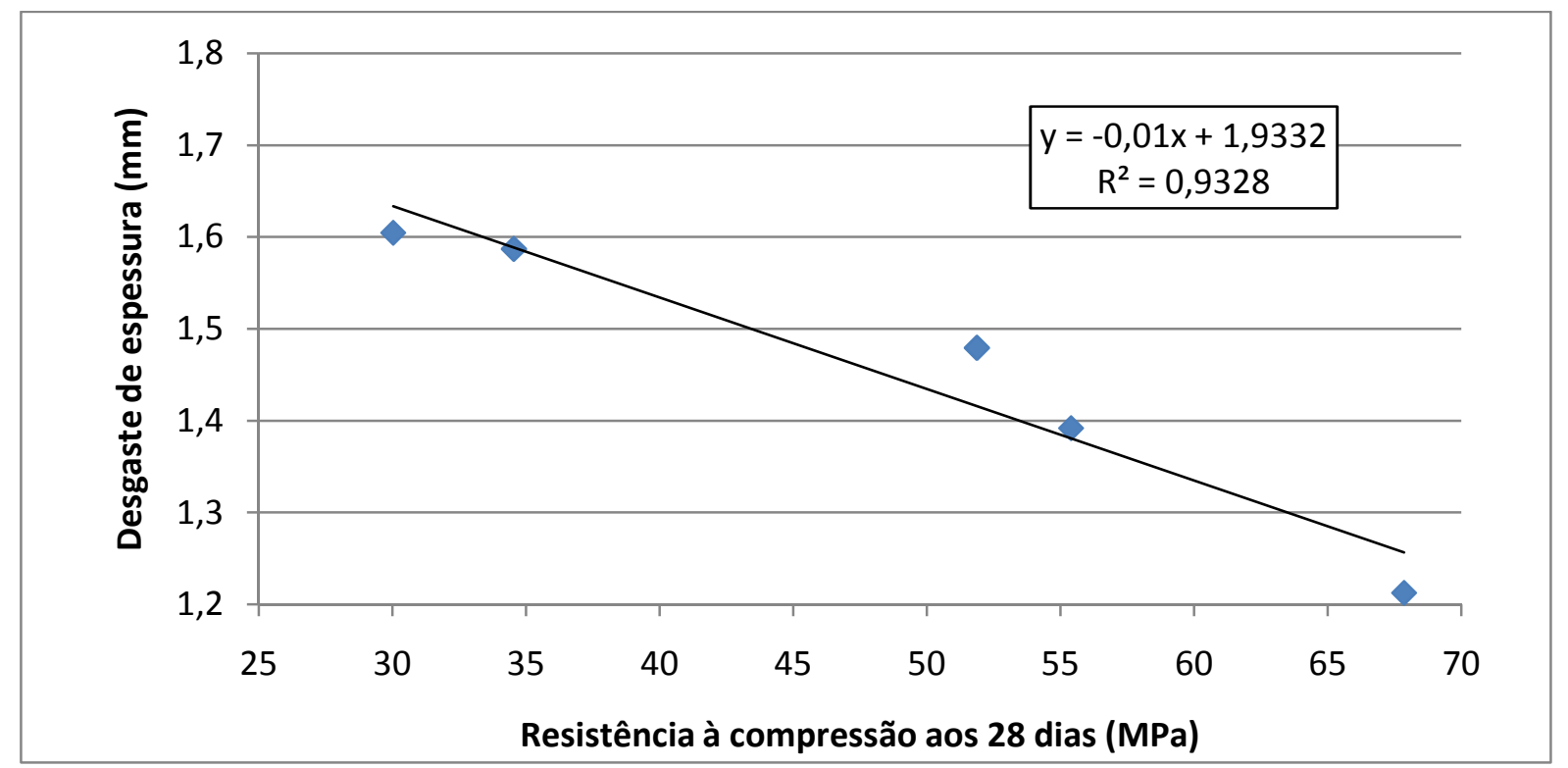

Figura 58 - Correlação entre desgaste por abrasão e resistência à compressão

Salienta-se mais uma vez que o ensaio realizado buscou medir a resistência potencial à abrasão. Por isto optou-se em ensaiar a face inferior dos corpos de prova, que fica em contato com a fôrma durante a moldagem, não sendo afetada por fatores negativos como a exsudação e acabamento superficial deficiente. Sabe-se que o desempenho à abrasão é dependente destes fatores, devendo na execução serem observadas operações de execução e cura adequadas para minimizá-los. 


\subsubsection{Permeabilidade}

O ensaio de permeabilidade que foi realizado é destinado à determinação rápida "in loco" da permeabilidade superficial de estruturas existentes. A pressão aplicada simulou a pressão existente no fundo de uma caixa d'água de $30 \mathrm{~m}$ de altura. Um resultado típico deste ensaio é mostrado na Figura 59. Inicialmente há um trecho de maior fluxo de água, devido à acomodação interna do aparelho, compressão de bolhas de ar e ar dissolvido existente na água, preenchimento das cavidades superficiais do concreto e estabelecimento do fluxo inicial no interior do concreto. Depois deste período inicial observa-se certa estabilização do fluxo, que lentamente vai ficando cada vez menor. Supõe-se que esta perda lenta deve-se ao fato de que o fluxo de água não é unidirecional, irradiando-se não só em profundidade, mas também lateralmente, alcançando progressivamente maiores volumes do concreto. Em função desta característica do ensaio optou-se por considerar um tempo mínimo igual para todos os concretos no qual se fez a medida. Com base nos resultados obtidos escolheu-se o intervalo de $4 \mathrm{~h}$ a $5 \mathrm{~h}$ como padrão para a medida do fluxo e cálculo do coeficiente de permeabilidade.

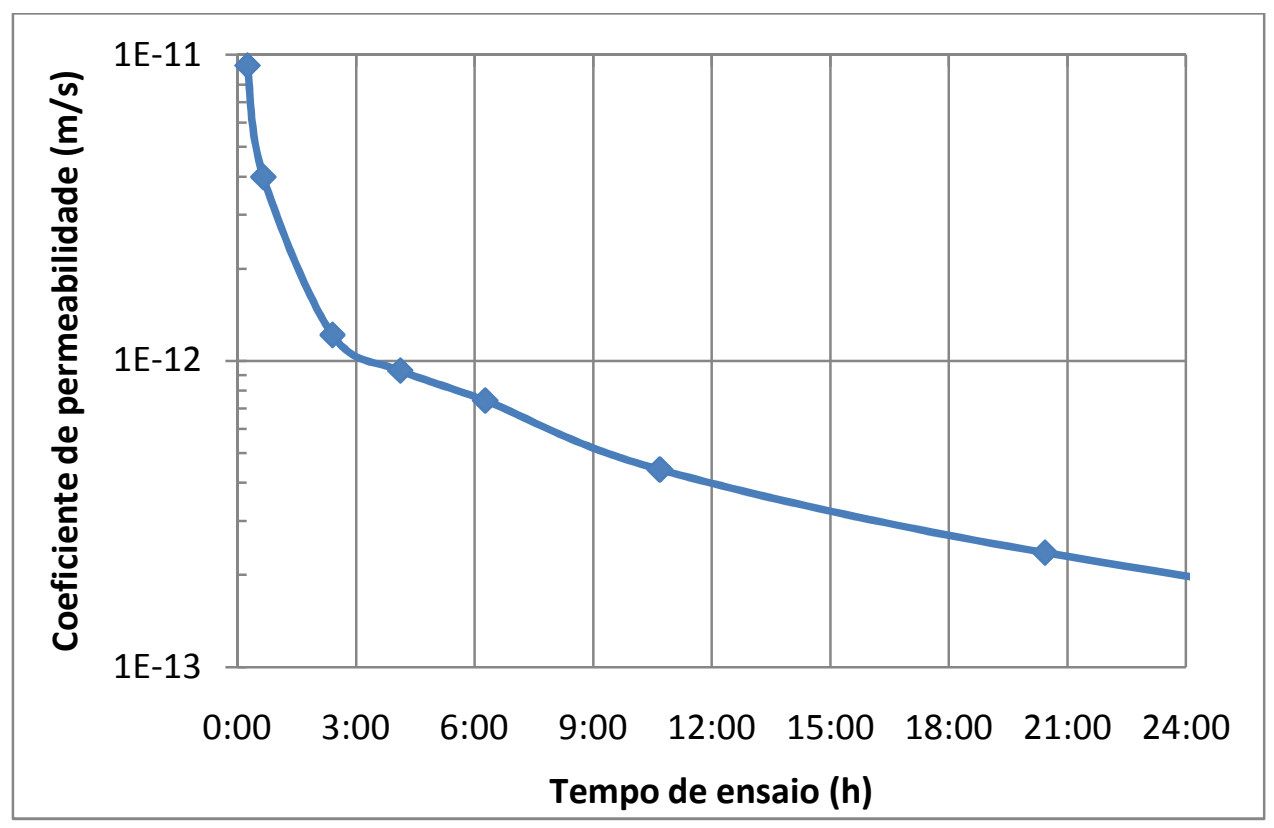

Figura 59 - Resultado típico de ensaio de permeabilidade

Os resultados assim obtidos devem ser observados com cautela pelos seguintes motivos:

- Variabilidade devido à heterogeneidade do concreto. A presença, dimensão e posição das partículas de agregado graúdo interferem na penetração da água; 
- O fluxo não pode ser considerado unidirecional. Considerando índice de vazios de 6 a $14 \%$ nos diversos concretos, conforme obtido no ensaio de absorção de água por imersão (ver Figura 52) e determinando o volume de água que ingressou no concreto no intervalo até $5 \mathrm{~h}$ pode-se calcular que apenas uma espessura de 1 a $4 \mathrm{~mm}$ foi preenchida com a água do ensaio. Como o concreto está saturado no início do ensaio, uma parcela equivalente de água teve que ser deslocada para as vizinhanças. Esta por sua vez desloca a água seguinte e assim sucessivamente até que um volume equivalente de água que ingressa atinge a superfície externa onde simplesmente evapora, já que o ensaio é realizado em ambiente aberto e o fluxo de água é muito pequeno para que seja detectada umidade superficial. Não se pode então de maneira simples determinar qual a região do concreto que é afetada pelo fluxo da água.

Apresentam-se a seguir os resultados (Tabela 23), para fins comparativos entre os traços e para se situar a ordem de grandeza da permeabilidade obtida. Para isto apresentase o intervalo de variação observado em quatro ensaios, sendo dois realizados na superfície inferior e dois na superfície superior do concreto. Sugere-se que, para obter dados mais confiáveis, seja realizado ensaio de permeabilidade que corrija as falhas apontadas no ensaio aqui realizado. Com base nestes resultados mais confiáveis pode-se inclusive verificar a precisão do ensaio realizado e propor ajustes de modo que este ensaio rápido permita avaliações com adequada aproximação.

Tabela 23 - Valores limites de coeficiente de permeabilidade determinados em ensaio de permeabilidade superficial rápida (Coeficiente de permeabilidade $\times 10^{-12} \mathrm{~m} / \mathrm{s}$ )

\begin{tabular}{ccccccc}
\hline Coeficiente de & \multicolumn{7}{c}{ Traços } \\
\cline { 2 - 7 } permeabilidade & V280 & V200 & VR4 & III280 & III210 & IIIR4 \\
\hline Valor superior & 1,9 & 3,5 & 3,9 & 2,9 & 8,4 & 5,2 \\
\hline Valor inferior & 0,9 & 1,9 & 1,2 & 1,9 & 1,0 & 1,0 \\
\hline
\end{tabular}

Como conclusão geral deste ensaio pode-se dizer que os concretos de baixo consumo de cimento possuem permeabilidade da mesma ordem de grandeza dos concretos de referência, podendo-se considerar a permeabilidade da ordem de $10^{-12} \mathrm{~m} / \mathrm{s}$, o que é uma permeabilidade baixa, podendo ser aplicado em reservatórios de água. Esta permeabilidade corresponde à vazão de $5 \mathrm{~L}$ de água por $\mathrm{m}^{2} / \mathrm{ano}$, no caso de uma parede de $20 \mathrm{~cm}$ de espessura. Caso a pressão hidrostática fosse o único mecanismo de transporte da água, e considerando índice de vazios em torno de $10 \%$, seriam necessários cerca de quatro anos para que a primeira água atravessasse esta parede. 
Deve-se lembrar que a maior parte dos problemas de vazamentos em reservatórios devem-se às deficiências na execução, principalmente falhas no adensamento, concretos com exsudação e/ou segregação, e processo de execução que permite a formação de juntas frias ou não as trata adequadamente no caso de ocorrência.

\subsubsection{Carbonatação}

A avaliação da velocidade com que se processa o fenômeno da carbonatação tem sido destacada por muitos trabalhos no campo da durabilidade, devido à sua estreita relação com o início do fenômeno de corrosão de armaduras. Assim como na maioria dos trabalhos sobre o assunto, aqui também se optou por realizar ensaio acelerado. As principais condições de ensaio contemplaram umidade relativa controlada em $65 \%$, formato de corpos de prova prismáticos, pré-condicionamento dos corpos de prova para permitir umidade interna próxima da externa e concentração de gás carbônico de 5 \%. A indicação da posição da frente de carbonatação se deu por aspersão de solução de fenolftaleína. A determinação da profundidade de carbonatação é realizada por meio de análise de imagens. Descrição detalhada do procedimento do ensaio e análise da imagem encontra-se na seção 4.5.4

$\mathrm{Na}$ Tabela 24 estão resumidos os resultados, com indicação de profundidade média, mínima e máxima para os seis traços. Em algumas combinações de traços/idades não foi possível calcular a espessura média, devido a fato de a carbonatação ser muito pequena, praticamente nula ao longo de boa parte da superfície externa da amostra. Estes casos estão descritos como "Não Definível" (N.D.), podendo ser desconsiderada a carbonatação nestes casos.

O fato que mais chama atenção de início é a diferença de desempenho entre os dois tipos de cimento. O CP III-40-RS apresentou profundidade de carbonatação bem superior ao CP V-ARI. Não há diferenças de porosidade consideráveis que justifiquem esta diferença. Inclusive a porosidade dos concretos com CP III-40-RS é ligeiramente inferior, segundo os ensaios de absorção de água vistos anteriormente. Atribui-se a maior profundidade de carbonatação à menor reserva alcalina (hidróxido de cálcio) disponível, devido ao menor teor de clínquer e maior teor de escória nos cimentos CP III-40-RS. A hidratação da escória granulada de alto-forno gera produtos de hidratação essencialmente similares aos originados da hidratação do clínquer, mas a quantidade de hidróxido de cálcio formado é bem menor (TAYLOR, 1990). 
Tabela 24 - Profundidades médias, máximas e mínimas da frente de carbonatação $(\mathrm{mm})$ para tempos de exposição até 96 dias.

\begin{tabular}{|c|c|c|c|c|c|c|c|}
\hline \multirow{2}{*}{$\begin{array}{c}\text { Tempo } \\
\text { exposição }\end{array}$} & \multirow{2}{*}{ Profundidade } & \multicolumn{6}{|c|}{ Traços } \\
\hline & & V280 & V200 & VR4 & III280 & III210 & IIIR4 \\
\hline \multirow{3}{*}{6 dias } & média & N.D. & 0,7 & N.D. & 1,7 & 3,9 & 2,9 \\
\hline & mínima & 0,0 & 0,0 & 0,0 & 0,1 & 0,6 & 0,4 \\
\hline & máxima & 1,5 & 4,8 & 2,6 & 4,9 & 9,1 & 6,0 \\
\hline \multirow{3}{*}{14 dias } & média & N.D. & 3,8 & N.D. & 4,2 & 10,4 & 6,7 \\
\hline & mínima & 0,0 & 0,0 & 0,0 & 0,0 & 5,2 & 3,0 \\
\hline & máxima & 3,4 & 12,1 & 6,8 & 8,6 & 21,1 & 11,4 \\
\hline \multirow{3}{*}{28 dias } & média & N.D. & 5,8 & N.D. & 5,5 & 14,1 & 8,8 \\
\hline & mínima & 0,0 & 1,2 & 0,0 & 2,3 & 7,8 & 4,8 \\
\hline & máxima & 3,6 & 12,2 & 2,2 & 9,6 & 22,7 & 19,6 \\
\hline \multirow{3}{*}{56 dias } & média & 2,0 & 8,8 & N.D. & 7,7 & 19,2 & 11,9 \\
\hline & mínima & 0,0 & 3,9 & 0,0 & 4,4 & 11,0 & 7,4 \\
\hline & máxima & 8,9 & 15,1 & 3,1 & 12,4 & 33,0 & 24,9 \\
\hline \multirow{3}{*}{96 dias } & média & 1,7 & 11,2 & N.D. & 9,8 & 22,3 & 14,6 \\
\hline & mínima & 0,0 & 4,6 & 0,0 & 5,7 & 17,5 & 6,4 \\
\hline & máxima & 7,9 & 17,1 & 4,6 & 18,7 & 29,7 & 25,1 \\
\hline
\end{tabular}

N.D. = Não Definível

Nos concretos com CP V-ARI, o de baixo consumo com $280 \mathrm{~kg} / \mathrm{m}^{3}$ de cimento é equivalente ao concreto de referência, apresentando, ambos, carbonatação muito baixa. $O$ traço com $200 \mathrm{~kg} / \mathrm{m}^{3}$ apresenta carbonatação identificável, porém pouco profunda se comparada à posição normalmente ocupada por armaduras.

Nos concretos com CP III-40-RS o melhor desempenho foi obtido no de baixo consumo com $280 \mathrm{~kg} / \mathrm{m}^{3}$ de cimento, melhor inclusive que o concreto de referência que possui cerca de $60 \%$ a mais de cimento. A maior profundidade de carbonatação é observada no traço de baixo consumo com apenas $210 \mathrm{~kg} / \mathrm{m}^{3}$ de cimento.

Estes resultados demonstram que existe claramente um balanço entre disponibilidade de material alcalino e porosidade. A importância de menor porosidade é crucial para o bom desempenho de concretos elaborados com cimentos que possuem teor de clínquer reduzido. Nestes concretos com baixo teor de cimento, a baixa porosidade é necessária para evitar problemas com carbonatação profunda e despassivação do aço.

Várias formulações têm sido propostas para estimar a profundidade de carbonatação ao longo do tempo. A equação mais frequentemente usada é a proposição de que a profundidade carbonatada é proporcional à raiz quadrada do tempo de exposição:

$$
x=k \sqrt{t-t_{0}}
$$

na qual $x$ é a profundidade carbonatada, $t$ é o tempo de exposição, to é o tempo de retardamento e $k$ é o coeficiente de carbonatação. O tempo de retardamento no caso deste 
ensaio será considerado nulo, pois foi realizado o pré-condicionamento dos corpos de prova. Sinais de carbonatação, mesmo que muito pequenos, puderam ser notados na menor idade de avaliação (6 dias) indicando que realmente a carbonatação não sofreu retardamento.

Calculando o coeficiente de carbonatação, por meio de regressão linear sobre os dados de ensaio obtidos, chega-se aos valores indicados na Tabela 25.

Tabela 25 - Coeficiente de carbonatação $\left(\mathrm{mm} \mathrm{dia}^{-1 / 2}\right)$ baseado nos resultados até 56 dias de exposição

\begin{tabular}{ccccccc}
\hline & \multicolumn{7}{c}{ Traços } \\
\cline { 2 - 7 } & V280 & V200 & VR4 & III280 & III210 & IIIR4 \\
\hline $\begin{array}{c}\text { Coeficiente de } \\
\text { carbonatação }\left(\mathrm{mm}_{\mathrm{dia}}{ }^{-1 / 2}\right)\end{array}$ & - & 1,11 & - & 1,01 & 2,43 & 1,55 \\
\hline $\mathrm{R}^{2}$ & - & 0,955 & - & 0,987 & 0,971 & 0,982 \\
\hline
\end{tabular}

Para o traço V280 não foi calculado o coeficiente de carbonatação, pois, com os tempos de exposição até 96 dias, não foi possível obter uma tendência crescente para o valor médio da profundidade de carbonatação. Também não foi calculado para o traço VR4, pois nem foi possível obter profundidades médias definíveis. Pode-se considerar que nestes dois traços a carbonatação é praticamente ausente. Tempos de exposição muito maiores seriam necessários para permitir a avaliação do comportamento destes traços ${ }^{54}$.

Silva (2007) correlacionou resultados de carbonatação em condição ambiental (concentração de $\mathrm{CO}_{2}$ de $0,04 \%$ ) com resultados obtidos em condições similares a deste trabalho, porém com concentrações de 1 e $50 \%$ de $\mathrm{CO}_{2}$. Os resultados obtidos indicam que, de modo aproximado, 1 dia de exposição a 1 \% de concentração equivale a meio ano de exposição ambiental e 1 dia de exposição a 50 \% de concentração equivale a 3 anos de exposição ambiental.

Supondo que estes resultados possam indicar uma ordem de grandeza da aceleração do ensaio e que também sejam representativos para os concretos deste trabalho ${ }^{55}$, pode-se supor que uma vida útil de 50 anos possa ser representada por 100 dias de ensaio em câmara de carbonatação a 1 \%. Considera-se esta concentração por ser mais

${ }^{54}$ Possan (2004, p. 143) cita que "para fins de modelagem e, conseqüentemente, melhor aproximação da vida útil das estruturas de concreto, o ensaio de carbonatação natural ou acelerado deve ser executado até a obtenção da curva de tendência ao estacionamento do fenômeno".

${ }^{55}$ A análise de correlação baseada no trabalho de SILVA (2007) deve ser entendida apenas como um indicativo de ordem de grandeza da carbonatação natural. Esta autora trabalhou com concretos utilizando cimento CP II-F-32, consumo de cimento em torno de $385 \mathrm{~kg} / \mathrm{m}^{3}$, baixo consumo de aditivo superplastificante e dois tipos de sílica ativa (de ferro silício e de casca de arroz). Em função da porosidade do concreto, tipo de cimento utilizado e reserva alcalina disponível, admite-se que pode haver variação na correlação entre ensaio acelerado e natural. 
próxima da utilizada neste ensaio, representando também uma avaliação conservadora. Com este tempo de ensaio e os coeficientes de carbonatação da Tabela 25 pode-se calcular a profundidade média prevista (Tabela 26 ). Considera-se ainda a variação entre a média e máxima observada nas diversas idades para avaliar a profundidade máxima que se pode esperar para o avanço da carbonatação. Esta análise aparenta ser conservadora, já que as profundidades máximas previstas ficaram acima das máximas registradas aos 96 dias, idade muito próxima de 100 dias.

Conforme esta estimativa, espera-se que os traços de baixo consumo de cimento, com exceção do III210, não apresentarão profundidade carbonatada que alcance a armadura em concretos com cobrimentos normais $(30 \mathrm{~mm})$ durante vida útil normal de 50 anos.

Tabela 26 - Estimativa de profundidade de carbonatação, em $\mathrm{mm}$, para a vida útil de 50 anos, equivalente a 100 dias de ensaio acelerado, baseado em resultados de Silva (2007)

\begin{tabular}{lcccccc}
\hline & \multicolumn{7}{c}{ Traços } \\
\cline { 2 - 7 } & V280 & V200 & VR4 & III280 & III210 & IIIR4 \\
\hline Profundidade média prevista & $2,0^{*}$ & 11,1 & $0,0^{\star *}$ & 10,1 & 24,3 & 15,5 \\
\hline $\begin{array}{c}\text { Maior variação entre } \\
\text { profundidade máxima e } \\
\text { média }\end{array}$ & 6,9 & 8,3 & 6,8 & 8,9 & 13,8 & 13,0 \\
\hline $\begin{array}{c}\text { Profundidade máxima } \\
\text { prevista }\end{array}$ & 8,9 & 19,4 & 6,8 & 19,0 & 38,1 & 28,5 \\
\hline *adotou-se a maior profundidade média detectada. \\
$* *$ adotou-se profundidade nula por não ter sido detectada profundidade média definível.
\end{tabular}

Os resultados dos ensaios de carbonatação sugerem que nas prescrições normativas deveria constar indicação a respeito do tipo de cimento empregado. Isto pode inclusive ser mais importante que a fixação indiscriminada de consumos mínimos de cimento. Pode-se, por exemplo, ver que os concretos com $200 \mathrm{~kg} / \mathrm{m}^{3}$ de cimento CP V-ARI tiveram resultados em termos de carbonatação melhores que os traços de referência com $437 \mathrm{~kg} / \mathrm{m}^{3}$ de cimento CP III-40-RS. Também o traço com $280 \mathrm{~kg} / \mathrm{m}^{3}$ de cimento CP V-ARI apresentou profundidade carbonatada tão baixa que poderia ser indicado para ambientes com maiores concentração de $\mathrm{CO}_{2}$, sem que houvesse problemas de despassivação de armadura por avanço excessivo da frente de carbonatação. Fica clara a falha das normas em não distinguir as exigências de agressividade conforme o tipo de cimento.

\subsubsection{Potencial de corrosão}

A medida do potencial de corrosão é uma técnica que fornece informação qualitativa a respeito do processo de corrosão. Mede-se a diferença de potencial entre a armadura 
imersa no corpo de prova e um eletrodo de referência de cobre/sulfato de cobre instalado sobre a superfície do concreto. Quanto maior a diferença de potencial registrada maior é a probabilidade de ocorrência de corrosão.

$\mathrm{Na}$ Figura 60 apresentam-se os resultados até 17 ciclos de ensaio. Cada ciclo representa uma semana, sendo quatro dias de secagem em estufa a $50{ }^{\circ} \mathrm{C}$ e três dias de imersão parcial em solução $\mathrm{NaCl}$ com concentração de 3,5\%. Os resultados mostram melhor desempenho dos concretos com cimento CP V-ARI, que se mantiveram estáveis em torno de $-200 \mathrm{mV}$, no limite entre o baixo e médio risco de corrosão, até 13 ciclos (3 meses). Já os concretos com CP III-40-RS, em geral, apresentaram potenciais maiores. Neste mesmo período o traço de referência e o de baixo consumo de cimento com $280 \mathrm{~kg} / \mathrm{m}^{3}$ de cimento estão enquadrados na classe de médio risco. $O$ traço com $210 \mathrm{~kg} / \mathrm{m}^{3}$ de cimento apresentou o pior desempenho, iniciando-se a corrosão das armaduras com apenas 4 semanas/ciclos de ensaio, passando à classe de risco severo com apenas 6 semanas/ciclos. Após os 13 ciclos iniciais os demais traços também indicam maior probabilidade de início de corrosão, com melhor desempenho dos concretos com baixo consumo de cimento CP V-ARI.

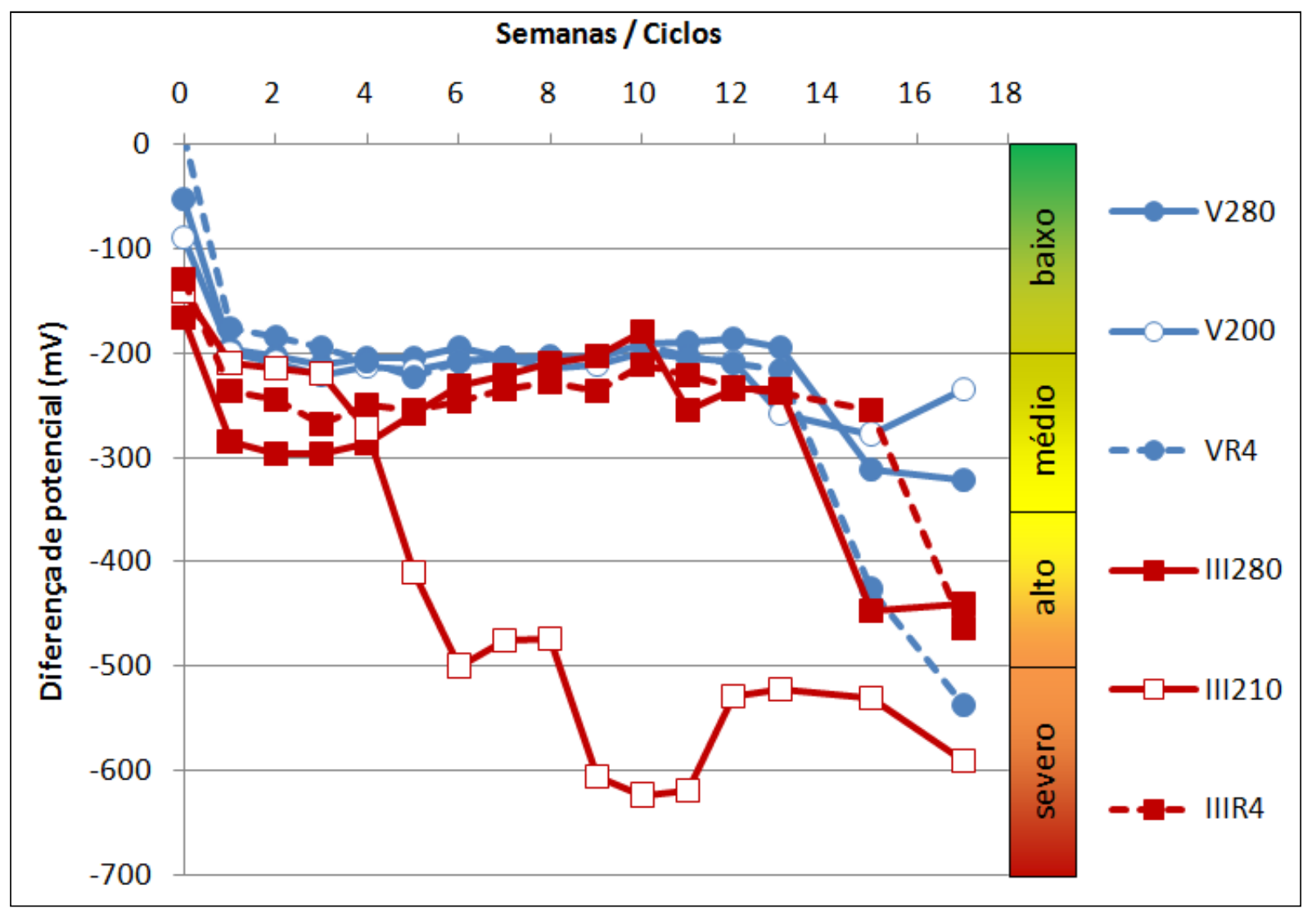

Figura 60 - Potencial de corrosão obtido ao longo de onze ciclos de exposição. 
O pior desempenho nos concretos com cimento CP III-40-RS pode ser explicado pela baixa quantidade de $\mathrm{C}_{3} \mathrm{~A}$ neste tipo de cimento. Os produtos de hidratação provenientes do $\mathrm{C}_{3} \mathrm{~A}$ promovem a fixação de íons cloreto. Nos cimentos CP III-40-RS, além de substituição de boa parte do clínquer por escória de alto forno, a sigla RS indica a maior resistência a sulfatos. Cimentos resistentes a sulfatos possuem baixo teor de $C_{3} A$. No caso dos concretos com baixo consumo de cimento o teor é ainda mais baixo devido à menor proporção de cimento empregado.

O resultado deste ensaio mostra que a durabilidade depende do tipo de cimento. Enquanto que os cimentos CP III-40-RS são indicados para ambientes com ataque de sulfatos, e também em casos de agregados reativos (reação álcalis-agregados), em situações de ataque de cloretos o desempenho não é tão bom. A durabilidade é sempre uma questão de balanço de fatores. A água do mar é excepcionalmente agressiva, pois, além de cloretos, contém também diversos sulfatos, além de vários outros fatores como umidade e aeração variável, agentes físicos, químicos e biológicos atuando simultaneamente na degradação do concreto. Deste ponto de vista seria interessante avaliar também outros tipos de cimento ou até misturas de cimentos (blends), onde se poderiam obter propriedades diferenciadas de maneira fácil, diretamente na obra, sem necessidade de alteração do processo de fabricação do cimento na indústria. Soluções deste tipo dependeriam apenas da disponibilidade de tipos de cimento diferentes e da avaliação experimental de acordo com os tipos de ataques sofridos pelo concreto.

As observações anteriores indicam também a necessidade de complementação das normas de concreto no quesito durabilidade. Na versão 2003 da ABNT NBR 6118, e posteriormente na atualização da ABNT NBR 12.655:2006, houve a inclusão pela primeira vez de critérios mais específicos de durabilidade, como a consideração de classes de agressividade e critérios limitantes para a confecção do concreto. Não foram, no entanto, feitas quaisquer restrições quanto ao tipo de cimento empregado. Normas internacionais já possuem critérios de durabilidade há mais tempo, algumas desde a década de 1960 . Atualmente apresentam diversas limitações quanto aos tipos de cimento. Em algumas situações todos os cimentos são permitidos, em outras alguns cimentos não são permitidos ou então tipos específicos são recomendados.

Como conclusão, baseada neste ensaio, pode-se dizer que dependendo do tipo de cimento utilizado, o uso de baixo consumo de cimento pode potencializar a redução da durabilidade. Esta conclusão, no entanto, não pode ser generalizada, já que com o cimento CP V-ARI isto não foi notado. Para maiores conclusões a respeito destes concretos, a complementação com outros ensaios se faz necessária, já que o ensaio de potencial de 
corrosão é de caráter apenas qualitativo. Recomenda-se que seja realizado ensaio de permeabilidade a cloretos e determinação de profundidade de penetração para complementar as observações.

\subsection{Avaliação de viabilidade econômica}

Para avaliar a viabilidade econômica da produção de concretos do tipo propostos neste trabalho inclui-se aqui esta breve avaliação de custos. Esta avaliação se restringe ao custo de materiais, considerando que não sejam necessárias grandes alterações de custos na mão de obra e equipamentos para a produção.

Na Tabela 27 são mostrados os custos unitários dos diversos materiais utilizados. Tratam-se de valores aproximados praticados na região de São Carlos / SP no ano de 2010.

Tabela 27 - Custos unitários dos materiais empregados $(\mathbf{R} \$ / \mathrm{kg})$

\begin{tabular}{ccccccc}
\hline Cimentos & $\begin{array}{c}\text { Sílica } \\
\text { Ativa }\end{array}$ & $\begin{array}{c}\text { Meta- } \\
\text { caulinita }\end{array}$ & $\begin{array}{c}\text { Brita 1/ } \\
\text { Pedrisco }\end{array}$ & Areias & $\begin{array}{c}\text { Fíler } \\
\text { SM500 }\end{array}$ & $\begin{array}{c}\text { Aditivo } \\
\text { SP }\end{array}$ \\
\hline 0,40 & 1,20 & 1,00 & 0,04 & 0,05 & 0,80 & 10,00 \\
\hline
\end{tabular}

$\mathrm{Na}$ Tabela 28 estão calculados os custos por $\mathrm{m}^{3}$ de cada um dos traços desenvolvidos. Para avaliação do custo benefício a terceira linha desta tabela mostra o custo relativo, tendo como base a resistência à compressão alcançada aos 28 dias.

Tabela 28 - Custos dos materiais dos traços desenvolvidos

\begin{tabular}{ccccccc}
\hline & $\mathbf{6 2 8 0}$ & $\mathbf{V 2 0 0}$ & $\mathbf{V R 4}$ & $\mathbf{I I 2 8 0}$ & $\mathbf{I I 2 1 0}$ & IIIR4 \\
\hline & 330,33 & 277,21 & 249,14 & 328,20 & 283,57 & 253,35 \\
\hline $\begin{array}{c}\text { Custo materiais } \\
\left(\mathrm{R} \$ \cdot \mathrm{m}^{-3}\right)\end{array}$ & 67,9 & 51,9 & 40,7 & 55,4 & 34,5 & 30,0 \\
\hline $\begin{array}{c}\text { Resistência } 28 \text { dias } \\
(\mathrm{MPa})\end{array}$ & 4,87 & 5,34 & 6,12 & 5,92 & 8,21 & 8,44 \\
\hline $\begin{array}{c}\text { Custo relativo } \\
\left(\mathrm{R} \$ \cdot \mathrm{m}^{-3} \cdot \mathrm{MPa}^{-1}\right)\end{array}$ & & & & &
\end{tabular}

Nota-se a viabilidade, já que o custo-benefício, expresso pelo custo relativo, é mais baixo em todos os concretos de baixo consumo de cimento. É necessário, porém, que, para o aproveitamento integral desta vantagem, o projetista da estrutura aproveite o melhor desempenho mecânico obtido.

Salienta-se que os valores são apenas indicativos, podendo as conclusões variarem com base nos custos de cada material nos diversos locais do Brasil. Também variações nas propriedades dos materiais podem resultar em desempenho diferenciado. Acredita-se que 
possa ser possível reduzir o custo total dos concretos de baixo consumo, realizando estudos de otimização de consumo, principalmente dos itens mais caros como adições minerais, superplastificante e fíler. Alterações na proporção destes materiais influenciam tanto o custo total como o desempenho, de modo que um estudo de otimização de custo se faz necessário para atingir menores custos totais e relativos. Por fim, para uma análise mais completa, seria necessário desenvolver estudo de campo para observar a viabilidade de produção, lançamento e aplicação deste concreto, a fim de obter dados mais completos de custos, incluindo os custos de equipamentos e mão de obra para produção e aplicação do concreto. 


\section{CONCLUSÃO E CONSIDERAÇÕES FINAIS}

A produção de concretos com baixo consumo de cimento Portland e alta resistência já é realidade no âmbito de pesquisa experimental, tendo sido elaborados diferentes tipos de concretos em vários trabalhos executados e divulgados pelo LMABC. A adoção em primeiros testes de campo esbarra em restrições normativas nacionais, especificamente a fixação de consumo mínimo de cimento pela ABNT NBR 12.655:2006. A razão para esta especificação decorre de preocupações com a durabilidade do concreto. Boa parte desta preocupação, porém, é remanescente do estilo de produção convencional de concreto, que ignora a aplicação de técnicas e produtos mais modernos.

Preocupações ambientais e de sustentabilidade da indústria cimenteira frente à perspectiva de crescimento contínuo da demanda de cimento nas próximas décadas, aliados a vantagens técnicas e econômicas, dão forte apoio ao desenvolvimento de concretos com reduzidos consumos de cimento. Uma gradativa mudança de ênfase observada na engenharia do concreto, de resistência para desempenho, exige que a avaliação do concreto considere aspectos de durabilidade.

Tendo razões suficientes para investir no desenvolvimento deste produto "novo" e promissor, passa a ser necessária a coleta de indícios de que o mesmo também se comporta adequadamente frente às agressões do ambiente no qual será inserido. Esta pesquisa experimental visa constituir-se de um estudo científico inicial para responder à indagação "estes concretos de baixo consumo de cimento, com já comprovado desempenho mecânico, também são duráveis?".

A produção do concreto com baixo consumo de cimento buscou a sinergia de diversos fatores apresentados na literatura e já aplicados em trabalhos anteriores no LMABC. Estas técnicas baseiam-se, sobretudo, na escolha adequada dos agregados, busca de um máximo empacotamento destes, inclusive com a incorporação de um fíler, adição de sílica ativa e metacaulinita como materiais pozolânicos e uso intensivo de aditivos superplastificantes. O bom desempenho mecânico obtido pode ser atribuído à melhora da zona de interface dos agregados com a pasta e refinamento da estrutura de poros desta. $O$ uso intensivo de aditivos de alto poder de plastificação e redução de água é necessário para obter relações água/aglomerante suficientemente baixos mesmo com os baixos consumos de cimento adotados. 
A aplicação destas técnicas permitiu a elaboração de quatro concretos com consumos de cimento de $279 \mathrm{~kg} / \mathrm{m}^{3}$ e $199 \mathrm{~kg} / \mathrm{m}^{3}$ para o cimento CP V-ARI e $276 \mathrm{~kg} / \mathrm{m}^{3}$ e $208 \mathrm{~kg} / \mathrm{m}^{3}$ de cimento CP III-40-RS. A escolha por dois tipos diferentes de cimento visou a avaliação da influência do teor de clínquer sobre o desempenho mecânico e de durabilidade.

Os concretos elaborados apresentaram alto abatimento (acima de $170 \mathrm{~mm}$ ) e adequado acabamento. Atenção especial deve ser dispensada aos casos de consumo total muito baixo de cimento, onde excessos de água e falta de finos podem provocar indesejável exsudação. Ajustes no teor de aditivo e no consumo de água e alteração da proporção de agregados e fíler, mesmo que isto provoque leve alteração no empacotamento, podem ser necessários quando se pretende utilizar consumos absolutos de cimento muito baixos.

Os ensaios mecânicos provaram que foi possível atingir altas resistências. A maioria dos resultados à compressão atingiu níveis superiores a $50 \mathrm{MPa}$, chegando a superar $80 \mathrm{MPa}$ aos 91 dias de idade para o concreto com $279 \mathrm{~kg} / \mathrm{m}^{3}$ de cimento CP V-ARI. É interessante citar que os concretos com mais baixo consumo total de cimento (próximos a $\left.200 \mathrm{~kg} / \mathrm{m}^{3}\right)$, apesar de terem relação água/aglomerante superior $(\mathrm{a} / \mathrm{agl} \approx 0,60)$ que os concretos de referência (a/agl $\approx 0,45$ e consumos acima de $420 \mathrm{~kg} / \mathrm{m}^{3}$ ), atingiram resistências até $27 \%$ superiores aos 28 dias e $46 \%$ aos 91 dias. Isto pode ser explicado pelo uso de aditivo superplastificante que contribui para uma boa dispersão das partículas. Nos concretos de referência a ausência do superplastificante prejudicou a dispersão das partículas finas e, consequentemente, dificultou a hidratação do cimento. Nos concretos com consumo de cimento de aproximadamente $280 \mathrm{~kg} / \mathrm{m}^{3}$ e relação a/agl equivalente a dos concretos de referência chega-se a atingir o dobro de resistência aos 91 dias de idade.

No ensaio de tração na flexão também se obtiveram ótimos resultados, superando em geral 6,0 MPa, chegando a 8,3 MPa no concreto com $279 \mathrm{~kg} / \mathrm{m}^{3}$ de cimento CP V-ARI. Correlações com as resistências à compressão, pelas fórmulas prescritas na ABNT NBR 6118:2003, indicam resultados acima da média, sendo bom indicativo para aplicação destes concretos em pisos industriais. A avaliação do módulo de elasticidade mostrou que estes concretos comportam-se de modo adequado com previsões usuais baseados na resistência à compressão. As altas resistências à compressão, portanto, conduziram a altos módulos de elasticidade, próximos a $50 \mathrm{GPa}$, e acima de $40 \mathrm{GPa}$ já com 7 dias de idade. Isto pode ser explicado pelo alto teor de agregados no concreto, graças ao efetivo empacotamento de partículas utilizado.

Uma avaliação do desempenho obtido, por meio da correlação entre resistência mecânica e consumo de cimento, aglomerantes e clínquer, mostrou que estes concretos atingiram excelentes resultados. Na compressão aos 28 dias atingiu-se consumos relativos 
de $3,8 \mathrm{~kg} \cdot \mathrm{m}^{-3} \cdot \mathrm{MPa}^{-1}$ de cimento (equivalente a $4,2 \mathrm{~kg} \cdot \mathrm{m}^{-3} \cdot \mathrm{MPa}^{-1}$ de materiais cimentícios e 3,6 kg. $\mathrm{m}^{-3} \cdot \mathrm{MPa}^{-1}$ de clínquer) com o cimento CP V-ARI e 5,0 kg. $\mathrm{m}^{-3} \cdot \mathrm{MPa}^{-1}$ de cimento (equivalente a $5,4 \mathrm{~kg} \cdot \mathrm{m}^{-3} \cdot \mathrm{MPa}^{-1}$ de materiais cimentícios e $2,4 \mathrm{~kg} \cdot \mathrm{m}^{-3} \cdot \mathrm{MPa}^{-1}$ de clínquer) com o cimento CP III-40-RS. Avaliação aproximada de emissão de $\mathrm{CO}_{2}$ indica também o bom desempenho ambiental deste tipo de concreto, chegando-se a emitir apenas $2,1 \mathrm{~kg} \cdot \mathrm{m}^{-3} \cdot \mathrm{MPa}^{-1}$ no caso do cimento CP III-40-RS.

Comparando os resultados dos tipos diferentes de cimento empregados, observaram-se maiores resistências com o cimento CP V-ARI, mesmo nas idades maiores (91 dias). Em ambos os cimentos, as resistências dos concretos apresentaram crescimentos superiores ao esperado dos 28 aos 91 dias, com o cimento CP III-40-RS apresentando ganhos superiores, fato justificado pela hidratação mais lenta da escória presente neste cimento. É possível que com idades mais altas ainda haja maior aproximação dos resultados entre os cimentos. Comparando os consumos relativos de clínquer nota-se, no entanto, que o cimento CP III-40-RS necessita de cerca de $30 \%$ menos clínquer que o CP V-ARI para produzir a mesma resistência. Isto demonstra a boa característica cimentante da escória contida neste cimento e também a viabilidade ambiental ao se empregar este tipo de cimento, pela redução na emissão de $\mathrm{CO}_{2}$ e bom aproveitamento de um rejeito industrial.

Comparação com concretos de referência convencionais indicam que estes resultados são sensivelmente melhores, chegando os melhores resultados a representar redução de consumo relativo de cimento e clínquer de até $66 \%$. Conclusões semelhantes foram obtidas ao se analisar o desempenho em termos de resistência à tração na flexão e módulo de elasticidade.

Comparando os consumos relativos obtidos com os divulgados em pesquisas nacionais e internacionais pode-se dizer que se tratam de resultados em níveis de altíssima desempenho. Comparando com 604 resultados nacionais e 981 internacionais compilados por Damineli et al. (2010) pode-se dizer que foi atingido valor recorde ao estabelecer consumo de materiais cimentícios de $4,2 \mathrm{~kg} \cdot \mathrm{m}^{-3} \cdot \mathrm{MPa}^{-1}$. Em ensaio exploratório inicial valores ainda menores foram obtidos, chegando a $3,7 \mathrm{~kg} \cdot \mathrm{m}^{-3} \cdot \mathrm{MPa}^{-1}$. Estes resultados, embora sejam pouco representativos devido à pequena quantidade de corpos de prova avaliados, indicam que ainda há potencial para futuras evoluções, tratando-se claramente de resultados inéditos e promissores. Vale lembrar que para a elaboração destes concretos não são necessários metodologias sofisticadas, nem materiais que não possam ser encontrados com facilidade no mercado nacional. 
Os concretos obtidos, comprovadamente de baixo consumo de cimento, foram avaliados com relação a diversos aspectos de durabilidade. Pelo fato de não existirem unidade ou ensaio únicos para avaliar e expressar de modo completo a durabilidade, foram aplicados diversos ensaios que buscaram contemplar alguns aspectos distintos de agressão, com ênfase especial na porosidade e permeabilidade do concreto, por meio dos quais boa parte dos mecanismos de degradação se processam. Executaram-se ensaios de absorção de água por imersão, absorção de água por capilaridade, permeabilidade, abrasão, carbonatação e potencial de corrosão. Os resultados obtidos, quando possível, foram comparados com valores citados na literatura. Foram elaborados concretos com os mesmos cimentos, como referência adicional, utilizando metodologia convencional e que atendesse à classe de agressividade mais severa (classe IV) da ABNT NBR 6118:2003.

O ensaio de absorção de água por imersão indicou baixa porosidade dos concretos de baixo consumo de cimento, inferiores aos concretos de referência e enquadrando-se na categoria de concretos de boa qualidade na classificação de diversos autores.

O ensaio de absorção por capilaridade também evidenciou bom desempenho, obtendo-se coeficientes de absorção capilar nos concretos de baixo consumo de cimento duas a quatros vezes menores que os coeficientes dos concretos de referência. Baixas frentes de capilaridade também foram observadas, sendo camadas de cobrimento comuns suficientes para evitar a penetração de água até às armaduras nos casos de contato esporádico com água, como, por exemplo, de chuva. Atribui-se esta redução ao refinamento e tortuosidade da rede capilar, obtidos graças à melhor dispersão das partículas finas, reação pozolânica das adições minerais e alto empacotamento dos agregados.

Durante a execução dos ensaios de absorção de água analisou-se a secagem dos corpos de prova, necessária para realização dos ensaios. Verificou-se que os procedimentos recomendados pelas normas nacionais (ABNT NBR 9778:2005 e NBR 9779:1995) não são adequados para conduzir à efetiva secagem do núcleo dos corpos de prova de concretos com baixa porosidade. Isto foi evidenciado pela observação da perda de água em período de secagem até quatro vezes superior ao especificado nas normas e também por método visual proposto neste trabalho, com uso de filme de sílica-gel como indicador de umidade. Portanto, os resultados de absorção por imersão e por capilaridade de concretos com baixa permeabilidade, deste trabalho e de muitos outros que predominantemente utilizam este mesmo procedimento, bem como classificações de qualidade dos concretos baseados nestes mesmos procedimentos de ensaio, devem ser considerados apenas comparativamente, não correspondendo à real porosidade. Sugere-se que as normas de absorção de água, em uma próxima revisão, alertem a respeito desta 
possível falsa interpretação de resultados no caso de concretos de baixa porosidade. Sugere-se também a inclusão do método de determinação de umidade com uso de filme de sílica-gel com indicador de umidade para identificação da real distribuição de água no interior dos corpos de prova, o que por vezes é difícil realizar apenas pela avaliação visual.

Os ensaios de abrasão indicam que os concretos propostos adequam-se facilmente a exigências medianas, como os resultantes de cargas médias, impactos pequenos, rodas rígidas e tráfego intenso de pedestres. A literatura mostra que resistências maiores somente são obtidas com uso de agregados especiais de alta dureza ou alto consumo de endurecedores de superfície. As profundidades desgastadas determinadas têm boa relação com as resistências à compressão, confirmando o previsto na literatura.

Para avaliação da permeabilidade utilizou-se ensaio para avaliação rápida "in loco" da permeabilidade em estruturas existentes. Esta técnica possui algumas características que dificultam a obtenção de resultados comparáveis aos obtidos em ensaios tradicionais. Testes adicionais e comparação com ensaios normatizados são recomendáveis para permitir conclusões mais precisas. Comparação com os concretos de referência, no entanto, indicam que os concretos de baixo consumo possuem permeabilidade de mesma ordem de grandeza, sendo adequados para uso em estruturas corriqueiras de armazenamento de água.

A avaliação da carbonatação, muito comum no estudo de durabilidade devido à relação com a despassivação e corrosão do aço, foi realizada por meio de ensaio acelerado, com concentração de $5 \%$ de $\mathrm{CO}_{2}$. Os resultados indicam desempenho diferenciado, conforme o tipo de cimento empregado. Baixas profundidades de carbonatação foram observadas com o uso de cimento CP V-ARI, inclusive para os menores consumos cimento. Nos concretos com cimento CP III-40-RS ficou mais evidente que a profundidade carbonatada depende não apenas da permeabilidade do concreto, mas também da disponibilidade de material alcalino (hidróxido de cálcio). Neste tipo de cimento, a substituição de clínquer por escória leva à formação de menor quantidade de hidróxido de cálcio, responsável pela fixação do gás carbônico que penetra no concreto. Mesmo assim, a profundidade carbonatada no concreto com $276 \mathrm{~kg} / \mathrm{m}^{3}$ de cimento CP III-40-RS foi inferior ao respectivo concreto de referência. Uma previsão de profundidade carbonatada em ambiente natural indica que todos os concretos, com exceção daquele com apenas $208 \mathrm{~kg} / \mathrm{m}^{3}$ de cimento CP III-40-RS, possuem capacidade de manter a frente de carbonatação afastada da armadura durante a vida útil.

Conclusão parecida a respeito da influência do tipo de cimento pode ser extraída dos resultados do ensaio de potencial de corrosão. Este ensaio, que fornece informação 
qualitativa a respeito do processo de corrosão, mostrou que concretos com cimento CP III-40-RS possuem risco maior de corrosão que aqueles executados com cimento $\mathrm{CP}$ V-ARI. Isto pode ser atribuído à menor quantidade de $\mathrm{C}_{3} \mathrm{~A}$ disponível no cimento resistente a sulfatos. Os produtos de hidratação originados do $\mathrm{C}_{3} \mathrm{~A}$ são capazes de fixar cloretos livres. Mesmo assim, durante o período no qual o ensaio foi conduzido, apenas o concreto com apenas $208 \mathrm{~kg} / \mathrm{m}^{3}$ de cimento CP III-40-RS mostrou claramente indícios de início de corrosão. O prosseguimento do ensaio é necessário para maiores conclusões a respeito do desempenho dos demais concretos.

Os resultados de carbonatação e potencial de corrosão ilustram bem como o estudo de durabilidade é amplo, e que uma avaliação específica das condições agressivas a que o concreto será submetido é necessária para torná-lo durável. Lembra-se que mesmo com adequada especificação do concreto não se garante que a estrutura produzida possa ser considerada durável. Deficiências na execução, como as advindas de lançamento, adensamento e cura inadequados, ou descimbramento inadequado, podem reduzir a vida útil da estrutura, mesmo sendo o concreto de alto desempenho. Até mesmo concepções estruturais equivocadas, que permitem formação de condições localizadas de agressividade não prevista, ou fissuração do concreto, contribuem para a redução da vida útil do concreto. Percebe-se que a especificação de concreto de alto desempenho é importante, mas deve ser acompanhado de processo de concepção e execução igualmente de alto desempenho.

Os resultados obtidos indicam que é possível elaborar concretos com baixo consumo de cimento e adequada durabilidade, comparável ou até mesmo superior às maiores exigências normativas, mesmo com consumos de cimento inferiores às mínimas especificadas por estas mesmas normas. Estes resultados concordam com a sugestão de outros pesquisadores de que há necessidade de revisão desta restrição normativa. Esta exigência, talvez adequada para concretos convencionais, se torna muito restritiva quando aplicada a concretos elaborados com materiais e técnicas avançadas. Torna-se, assim, empecilho ao avanço tecnológico, dificultando a adoção de concretos mais desenvolvidos, além de ir na contramão da busca pela sustentabilidade ambiental e do negócio do cimento. A consideração a respeito do tipo de cimento utilizado também necessita ser incorporada nas especificações normativas, pois tem grande influência em alguns casos. 


\subsection{Sugestões para prosseguimento da pesquisa}

Concretos semelhantes aos desenvolvidos neste trabalho têm bom potencial de aplicação. O aprofundamento na pesquisa é necessário para se conhecer melhor o seu comportamento, adequando-o à aplicação em obras. Algumas sugestões para o prosseguimento da pesquisa são dadas a seguir:

- Aprofundamento da avaliação de durabilidade, com a inclusão de outros ensaios, como, por exemplo, penetração de cloretos, porosimetria por injeção de mercúrio, resistência química a soluções ácidas e açúcares e resistência a sulfatos. Também uma reavaliação da permeabilidade, com outro tipo de ensaio, é recomendada;

- Avaliação dos requisitos de durabilidade com concretos elaborados com outros tipos de cimento ou misturas de cimentos diferentes (blends);

- Análise da influência do alto consumo de aditivo superplastificante sobre a pega do cimento e endurecimento do concreto;

- Mensuração das vantagens técnicas esperadas de concretos com baixo consumo de cimento, tais como menor retração, fissuração e calor de hidratação;

- Avaliação da reologia. Embora os concretos tenham alto abatimento e se deformem com facilidade ao aplicar vibração, possuem alta coesão, o que pode dificultar o seu manejo. Avaliação dos parâmetros reológicos, e possíveis ajustes nos traços para facilitar a aplicação dos concretos, podem ser necessários;

- Estudo de alternativas de empacotamento e relacionamento com a reologia;

- Avaliação de simplificação dos traços, com menor diversidade de materiais, para facilitar a adoção em obras;

- Avaliação técnica-econômica dos componentes dos traços, de modo a reduzir o custo total dos materiais de $u m \mathrm{~m}^{3}$ de concreto. Neste sentido, a busca por aditivos, adições e fíler com melhor relação custo/benefício é indicada;

- Teste de produção em condições reais de obras. Sugere-se avaliação de mistura em caminhão betoneira e em misturadores horizontais. Avaliar, com base nestes testes, a influência da mistura sobre a trabalhabilidade e desempenho do concreto.

- Realização de dosagens exploratórias de concretos com consumos de cimento ainda menores, abaixo de $200 \mathrm{~kg} / \mathrm{m}^{3}$, mesmo que isto proporcione o não preenchimento completo do esqueleto granular. 


\section{REFERÊNCIAS BIBLIOGRÁFICAS}

AMERICAN ASSOCIATION OF STATE HIGHWAY AND TRANSPORTATION OFFICIALS. AASHTO T277: standard method of test for electrical indication of concrete's ability to resist chloride ion penetration. Washington DC, 2005.

ASSOCIAÇÃO BRASILEIRA DE NORMAS TÉCNICAS. NBR 5733: cimento Portland de alta resistência inicial. Rio de Janeiro, 1991.

NBR 5735: cimento Portland de alto-forno. Rio de Janeiro, 1991.

NBR 5736: cimento Portland pozolânico. Rio de Janeiro, 1991.

NBR 5738: concreto: procedimento para moldagem e cura de corpos-de-prova. Rio de Janeiro, 2003. Janeiro, 2007.

NBR 5739: concreto: ensaios de compressão de corpos-de-prova cilíndricos. Rio de

NBR 6118: projeto de estruturas de concreto: procedimento. Rio de Janeiro, 2003.

NBR 7211: agregados para concreto: especificação. Rio de Janeiro, 2009.

NBR 8522: concreto: determinação do módulo estático de elasticidade à compressão. Rio de Janeiro, 2008.

NBR 9457: ladrilho hidráulico: especificação. Rio de Janeiro, 1986.

NBR 9778: argamassa e concreto endurecidos: determinação da absorção de água, índice de vazios e massa específica: método de ensaio. Rio de Janeiro, 2005.

NBR 9779: argamassa e concreto endurecidos: determinação da absorção de água por capilaridade. Rio de Janeiro: método de ensaio. Rio de Janeiro, 1995.

NBR 9833: concreto fresco: determinação da massa específica, do rendimento e do teor de ar pelo método gravimétrico. Rio de Janeiro, 2008.

NBR 10786: concreto endurecido: determinação do coeficiente de permeabilidade à água: método de ensaio. Rio de Janeiro, 1989.

Janeiro, 2008.

NBR 10908: aditivos para argamassa e concreto: ensaios de caracterização. Rio de

NBR 11768: aditivos para concreto de cimento Portland: especificação. Rio de Janeiro, 1992.

NBR 11801: argamassa de alta resistência mecânica para pisos: especificação. Rio de Janeiro, 1992. 
NBR 12042: materiais inorgânicos: determinação do desgaste a abrasão: método de ensaio. Rio de Janeiro, 1992.

NBR 12142: concreto: determinação da resistência à tração na flexão de corpos de prova prismáticos. Rio de Janeiro, 2010.

NBR 12655: concreto de cimento Portland: preparo, controle e recebimento: procedimento. Rio de Janeiro, 2006.

NBR 15575: edifícios habitacionais de até cinco pavimentos: desempenho: parte 1: Requisitos gerais. Rio de Janeiro, 2008.

NBR NM 23: cimento Portland e outros materiais em pó: determinação da massa específica. Rio de Janeiro, 2000.

NBR NM 45: agregados: determinação da massa unitária e do volume de vazios. Rio de Janeiro, 2006.

NBR NM 52: agregado miúdo: determinação da massa específica e massa específica aparente. Rio de Janeiro, 2009.

NBR NM 53: agregado graúdo: determinação da massa específica, massa específica aparente e absorção de água. Rio de Janeiro, 2009.

NBR NM 67: concreto: determinação da consistência pelo abatimento do tronco de cone. Rio de Janeiro, 1998.

Janeiro, 2003.

NBR NM 248: agregados: determinação da composição granulométrica. Rio de

AMERICAN CONCRETE INSTITUTE. Comittee 201. ACI 201.2R: guide to durable concrete. Farmington Hills/Michigan/USA, 2008.

AGULLÓ, L.; TORALLES-CARBONARI, B.; GETTU R.; AGUADO, A. (1999). Fluidity of cement pastes with mineral admixtures and superplasticizer: a study based on the Marsh cone test. Materials and Structures, v. 32, n. 7, p. 479-485, ago.-set. 1999.

AïTCIN, P. C. (2000). Concreto de alto desempenho. Tradução Geraldo G. Serra; São Paulo: Pini, 2000. 667 p.

ALVES, J. D. (1978). Manual de tecnologia do concreto. São Paulo: Nobel, 1978. 156 p.

ANDERSON, S.; NEWELL, R. (2004). Prospects for carbon capture and storage technologies. Annual Review of Environment and Resources, v. 29, p. 109-142, 2004.

ANDRADE PERDRIX, M. D. C. (1992). Manual para diagnóstico de obras deterioradas por corrosão de armaduras. Tradução e adaptação CARMONA, A.; HELENE. P.; São Paulo: Pini, 1992. 103 p.

ANDRADE, T. (2005). Tópicos sobre durabilidade do concreto. In: ISAIA, G. C. (ed.). Concreto: Ensino, Pesquisa e Realizações. São Paulo: IBRACON, 2005. Cap. 25, p. 753793. 
ANDRADE, W. P. (editor) (1997). Concretos - Massa, estrutural, projetado e compactado com rolo: ensaios e propriedades. São Paulo: Pini, 1997.

AMERICAN SOCIETY FOR TESTING AND MATERIALS. C231/C231M: standard test method for air content of freshly mixed concrete by the pressure method. West Conshohocken/Pennsylvania/USA, 2010.

C876: standard test method for half-cell potentials of uncoated reinforcing steel in concrete. Conshohocken/Pennsylvania/USA, 1991.

BASF (2011). Glenium ${ }^{\circledR} 160$ SCC (Ficha técnica de produto). Disponível em: <http://www.basf-cc.com.br/PT/produtos/aditivos/GLENIUM160SCC/Documents/GLENIUM \%C2\%AE\%20 160\%20SCC.pdf>. Acesso em: 18 mar. 2011.

BENTZ, D. P. (2005). Replacement of "Coarse" Cement Particles by Inert Fillers in Low W/C Ratio Concretes II: Experimental Validation. Cement and Concrete Research, v. 35, n. 1, p. 185-188, jan. 2005.

BENTZ, D. P.; CONWAY, J. T. (2001). Computer modeling of the replacement of "coarse" cement particles by inert fillers in low $w / c$ ratio concretes Hydration and strength. Cement and Concrete Research, v. 31. n. 3, p. 503-506, mar. 2001.

BERNSTEIN, L.; ROY, J.; DELHOTAL, K. C.; HARNISCH, J.; MATSUHASHI, R.; PRICE, L.; TANAKA, K.; WORRELL, E.; YAMBA, F.; FENGQI, Z. (2007). Industry. In: METZ, B.; DAVIDSON, O. R.; BOSCH, P. R.; DAVE, R.; MEYER, L. A. (eds.). Climate change 2007: Mitigation of climate change. Working Group III Contribution to the Fourth Assessment Report of the Intergovernmental Panel on Climate Change. Cambridge/United Kingdom e New York/USA: Cambridge University Press, 2007. Cap. 7, p. 447-496.

BERTOS, M. F.; SIMONS, S. J. R., HILLS, C. D.; CAREY, P. J. (2004). A review of accelerated carbonation technology in the treatment of cement-based materials and sequestration of $\mathrm{CO}_{2}$. Journal of Hazardous Materials, v. 112, n. 3, p. 193-205, ago. 2004.

BRITISH STANDARDS INSTITUTION. BS 8500: concrete - complementary British standard to BS EN 206-1.(in two parts). London, 2006.

BS EN 1097-8: tests for mechanical and physical properties of aggregates: determination of the polished stone value. London, 2009.

BS 812-113: testing aggregates: method for determination of aggregate abrasion value (AAV). London, 1990.

CASTRO, A. L. (2007). Aplicação de conceitos reológicos na tecnologia dos concretos de alto desempenho. 2007. 302 f. Tese (Doutorado em Ciência e Engenharia de Materiais) - Interunidades (Instituto de Física de São Carlos/ Instituto de Química de São Carlos/ Escola de Engenharia de São Carlos), Universidade de São Paulo, São Carlos, 2007.

CATOIA, T. (2007). Ladrilhos e revestimentos hidráulicos de alto desempenho. 2007. 111 f. Dissertação (Mestrado em Engenharia Civil) - Escola de Engenharia de São Carlos, Universidade de São Paulo, São Carlos, 2007.

CATOIA, T.; CATOIA, B.; PEREIRA, T. A. C.; CATAI, E.; LIBORIO, J. B. L. (2008a). Concreto de alta resistência com baixo consumo de cimento. In: CONGRESSO 
BRASILEIRO DO CONCRETO, 50., 2008, Salvador. Anais eletrônicos... São Paulo: IBRACON, 2008. p. 11.

CATOIA, T.; PEREIRA, T. A. C.; CATOIA, B.; SANCHES JR., J. E. R.; CATAI, E.; LIBORIO, J. B. L. (2008b). Concreto auto-adensável com baixo consumo de cimento. In: CONGRESSO BRASILEIRO DO CONCRETO, 50., 2008, Salvador. Anais eletrônicos... São Paulo: IBRACON, 2008. p. 13.

CATOIA, T.; CONCEIÇÃO, R. V.; LIBORIO, J. B. L. (2009). Concreto com baixo consumo de cimento. In: CONGRESSO BRASILEIRO DO CONCRETO, 51., 2009, Curitiba. Anais eletrônicos... São Paulo: IBRACON, 2009. p. 11.

CEB-FIB - COMITÉ EURO-INTERNATIONAL DU BÉTON \& FÉDÉRATION INTERNATIONALE DU BÉTON. Bulletin 213/214: model code 90. Lausanne/Switzerland, 1993.

CEMBUREAU - EUROPEAN CEMENT ASSOCIATION. (2010). Activity report 2009. Bruxelas/Bélgica: Cembureau, 2010.

CEN - COMITÉ EUROPÉEN DE NORMALISATION. EN 1990: basis of structural design. Bruxelas/Bélgica, 2002.

EN 206-1: concrete: part 1: specification, performance, production and conformity. Bruxelas/Bélgica, 2000.

EN 13295: products and systems for the protection and repair of concrete structures: test methods: determination of resistance to carbonation. Bruxelas/Bélgica, 2004.

CHEYREZY, M.; MARET, V.; FROUIN, L. (1995). Microstructural analysis of RPC (reactive powder concrete). Cement and Concrete Research, v. 25, n. 7, p. 1491-1500, out. 1995.

CHIOCCHIO, G.; PAOLINI, A. E. (1985). Optimum time for adding superplasticizers to portland cement pastes. Cement and Concrete Research, v. 15, n. 5, p. 901-908, set. 1985.

COLLEPARDI, M. (1998). Ordinary and long-term durability of reinforced concrete structures. In: CANMET/ACI/JCI INTERNATIONAL CONFERENCE, 4th., 1998, Tokushima/Japan. Proceedings. Farmington Hills: ACI, 1998. v. 1, p. 87-106.

CSI - THE CEMENT SUSTAINABILITY INITIATIVE. (2007). The cement sustainability initiative. Suíça: World Business Council for Sustainable Development, 2009. 7 p.

(2009a). Recycling Concrete. Suíça: World Business Council for Sustainable Development, 2009. 40 p.

(2009b). Cement industry energy and $\mathrm{CO}_{2}$ performance: "Getting the numbers right”. Suíça: World Business Council for Sustainable Development, 2009. 43 p.

(2009c). Cement technology roadmap 2009: Carbon emissions reductions up to 2050. Suíça: World Business Council for Sustainable Development, 2009. 33 p. 
DAL MOLIN, D. C. C. (2005). Adições minerais para concreto estrutural. In: ISAIA, G. C. (ed.). Concreto: Ensino, Pesquisa e Realizações. São Paulo: IBRACON, 2005. Cap. 12, p. 345-380.

DAMINELI, B. L.; KEMEID, F. M.; AGUIAR, P. S.; JOHN, V. M. (2010). Measuring the ecoefficiency of cement use. Cement and Concrete Composites, v. 32, n. 8, p. 555-562, set. 2010.

DE LARRARD, F. (1999). Concrete mixture proportioning: a scientific approach. London: E \& FN Spon, 1999. 421 p. (Modern Concrete Technology Series, 9).

DHIR, R. K.; MCCARTHY, M. J.; NEWLANDS, M. D. (2004). Challenges in designing concrete durability: a sustainable approach. In: INTERNATIONAL CONFERENCE: BETON 2004, 10-12 jun. 2004, Istanbul. Proceedings. Istanbul: 2004, p. 322-339.

DÍAZ, V. O. (1998). Método de dosagem de concreto de elevado desempenho. São Paulo: Pini, 1998. $122 \mathrm{p}$.

DIN - DEUTSCHES INSTITUT FÜR NORMUNG. DIN 1045-2: concrete, reinforced and prestressed concrete structures - Part 2: concrete: specification, properties, production and conformity: application rules for DIN EN 206-1. Berlin/Alemanha, 2008.

DNIT - DEPARTAMENTO NACIONAL DE INFRAESTRUTURA DE TRANSPORTES. DNIT 056/2004 ES: pavimento rígido: sub-base de concreto de cimento Portland compactado com rolo: especificação de serviço. Brasília, 2004.

DNIT 059/2004 ES: pavimento rígido: pavimento de concreto de cimento Portland, compactado com rolo: especificação de Serviço. Brasília, 2004.

ELKEM (2008) Elkem Microsilica®: Grade 920 for construction. Disponível em: <http://www.concrete.elkem.com/dav/cd10e31b9b.pdf>. Acesso em: 18 mar. 2011.

EPE \& IDDRI - Enterprises pour l'Environnement \& International Institute for Sustainable Development and International Relations. (2008). Scenarios for transition towards a low carbon world in 2050: What's at stake for heavy industries? EPE \& IDDRI: Paris, 2008. 6 p.

FALCÃO BAUER, R. J.; TAKASHIMA, S.; MELO, C. E. S. (2004). Propriedades mecânicas do concreto de ultra-resistência. In: CONGRESSO BRASILEIRO DO CONCRETO, 46., 2004, Florianópolis. Anais eletrônicos... São Paulo: IBRACON, 2004, p. 16.

FIGUEIREDO, E. P. (2005). Efeitos da Carbonatação e de Cloretos no Concreto. In: ISAIA, G. C. (ed.). Concreto: Ensino, Pesquisa e Realizações. São Paulo: IBRACON, 2005. Cap. 27, p. 829-855.

FORMAGINI, S. (2005). Dosagem Científica e Caracterização Mecânica de Concretos de Altíssimo Desempenho. 2005. 259 f. Tese (Doutorado em Ciências em Engenharia Civil.) - Universidade Federal do Rio de Janeiro (COPPE-UFRJ), Rio de Janeiro, 2005.

GAJDA, J.; ALSAMSAM, E. (2006). Engineering Mass Concrete Structures. Skokie/USA: Portland Cement Association, 2006. p. 7. (Professional Development Series). 
GOLDBACH, U.; STEHLING, S. (2008). Precasting of UHPC elements. In: INTERNATIONAL SYMPOSIUM ON ULTRA HIGH PERFORMANCE CONCRETE, 2nd., 05-07 mar. 2008, Kassel/Germany. Proceedings... Kassel/Germany: Kassel University Press, 2008. p. 589595.

HASPARYK, N. P.; LOPES, A. N. P.; ANDRADE, M. A. S.; SANTOS, S. B. (2005). Deformações por Retração e Fluência. In: ISAIA, G. C. (ed.). Concreto: Ensino, Pesquisa e Realizações. São Paulo: IBRACON, 2005. Cap. 22, p. 654-685.

HELENE, P. R. L. (1993). Contribuição ao estudo da corrosão em armaduras de concreto armado. 1993. 231 f. Tese (Livre-docência). Escola Politécnica da Universidade de São Paulo, São Paulo, 1993.

(2005). Dosagem do concreto de cimento Portland. In: ISAIA, G. C. (ed.). Concreto:

Ensino, Pesquisa e Realizações. São Paulo: IBRACON, 2005. Cap. 15, p. 439-472.

HELENE, P. R. L.; TERZIAN, P. (1993). Manual de dosagem e controle do concreto. São Paulo: Pini, 1993. 349 p.

HUMPHREYS, K.; MAHASENAN, M. (2002). Toward a sustainable cement industry: Substudy 8: Climate Change. Geneva/Switzerland: World Business Council for Sustainable Development (WBCSD), 2002. 92 p.

IBRACON - INSTITUTO BRASILEIRO DO CONCRETO. (2007). Comentários técnicos e exemplos de aplicação da NB-1. São Paulo: IBRACON, 2007. 257 p.

IEA - INTERNATIONAL ENERGY AGENCY. (2007). Tracking Industrial Energy Efficiency and $\mathrm{CO}_{2}$ emissions. Paris/France: International Energy Agency, 2007. 321 p.

(2008). Energy technology perspectives 2008: Scenarios \& Strategies to 2050. Paris/France: International Energy Agency, 2008. 643 p.

IPCC - INTERGOVERNMENTAL PANEL ON CLIMATE CHANGE. (2007) Summary for Policymakers. In: SOLOMON, S.; QIN, D.; MANNING, M.; CHEN, Z.; MARQUIS, M.; AVERYT, K. B.; TIGNOR M.; MILLER, H. L. (eds.). Climate Change 2007: The Physical Science Basis. Working Group I Contribution to the Fourth Assessment Report of the Intergovernmental Panel on Climate Change. Cambridge/United Kingdom e New York/USA: Cambridge University Press, 2007. 18 p.

JOHN, V. M. (2003). On the sustainability of the concrete. Disponível em: < http://vmjohn.pcc.usp.br/Arquivos/On\%20the\%20Sustainability\%20of\%20the\%20Concrete.p df $>$. Acesso em: 18 mar. 2011. (versão estendidas do artigo enviado ao UNEP Journal Industry and Environment, v. 26, n. 2-3, p. 62-63, abr.-set. 2003).

JOSA, A.; AGUADO, A.; HEINO, A.; BYARS, E.; CARDIM, A. (2004). Comparative analysis of available life cycle inventories of cement in the EU. Cement and Concrete Research, v. 34, n. 8, p. 1313-1320, ago. 2004.

KIHARA, Y; CENTURIONE, S. L. (2005). O cimento Portland. In: ISAIA, G. C. (ed.). Concreto: Ensino, Pesquisa e Realizações. São Paulo: IBRACON, 2005. Cap. 10, p. 295322. 
KOEHLER, E. P.; FOWLER, D. W. (2007). Aggregates in Self-Consolidating Concrete. Austin/Texas/USA: International Center for Aggregates Research (ICAR): 2007, 353 p. (final report ICAR project 108).

KRELAUS, R.; SCHMIDT, M.; FREISINGER, S. (2008). Adhesive bonding of UHPC structural members at the Gaertnerplatz bridge in Kassel. In: INTERNATIONAL SYMPOSIUM ON ULTRA HIGH PERFORMANCE CONCRETE, 2nd., 05-07 mar. 2008, Kassel/Germany. Proceedings... Kassel/Germany: Kassel University Press, 2008. p. 597604.

KULAKOWSKI, M. P. (2002). Contribuição ao estudo da carbonatação em concretos e argamassas compostos com adição de sílica ativa. 2002. 180 f. Tese (Doutorado em Engenharia) - Curso de Pós-graduação em Engenharia de Minas, Metalúrgica e de Materiais, Universidade Federal do Rio Grande do Sul, Porto Alegre, 2002.

KUPERMAN, S. C. (2005). Concreto massa convencional e compactado com rolo para barragens. In: ISAIA, G. C. (ed.). Concreto: Ensino, Pesquisa e Realizações. São Paulo: IBRACON, 2005. Cap. 41, p. 1260-1295.

LIBORIO, J. B. L. (1990). Estudo patológico das construções de argamassa armada existentes no Brasil. 1990. 322 f. Tese (Doutorado em Engenharia de Estruturas) - Escola de Engenharia de São Carlos, Universidade de São Paulo, São Carlos, 1989.

LIBORIO, J. B. L. (2003). Concreto de alto desempenho: uma tecnologia simples para produção de estruturas duráveis. Notas de aula, disciplina de pós-graduação SET 5891 Tecnologia dos concretos estruturais. São Carlos: Departamento de Engenharia de Estruturas, EESC, Universidade de São Paulo, 2007, p. 42.

LIMA, M. G. (2005). Ação do meio ambiente sobre as estruturas de concreto. In: ISAIA, G. C. (ed.). Concreto: Ensino, Pesquisa e Realizações. São Paulo: IBRACON, 2005. Cap. 24, p. $713-752$.

LOBO CARNEIRO, F. L. (1943). Dosagem de Concretos. Rio de Janeiro: Instituto Nacional de Tecnologia, 1943. $110 \mathrm{p}$.

MANGAT, P. S.; MOLLOY, B. T. (1992). Factors influencing chloride-induced corrosion of reinforcement in concrete. Materials and Structures. v. 25, n. 7, p. 404-411, ago. 1992.

MARTINS, L. C.; RUFINO, M. S.; MOTTA, C. F. C.; BRAGA, J. A.; ABREU, C. M. (2006). Piso de Alta Resistência. In: CONGRESSO BRASILEIRO DO CONCRETO, 48., 2006, Rio de Janeiro. Anais eletrônicos... São Paulo: IBRACON, 2006, p. 17.

MARTINS, M. L. C.; CAÑAS_GUILLEN, C. (2004). Comportamento de Argamassa de Alta Resistência para Pisos Industriais utilizando Agregado Mineral do Rio Camaquã. In: CONGRESSO BRASILEIRO DO CONCRETO, 46., 2004, Florianópolis. Anais... São Paulo: IBRACON, 2004, v. II, p. 459-468.

MASO, J. C. (1996). Rilem Report 11: Interfacial Transition Zone in Concrete. E\&FN SPON, Chapman \& Hall, London, (1996).

MATTOS, M. L. (2004). Pisos industriais de concreto. Revista Téchne, São Paulo, v. 89, p. 34-40, ago. 2004. 
MEHTA, P. K.; MONTEIRO, P. J. M. (2008). Concreto: microestrutura, propriedades e materiais. Tradução da 3. ed. em inglês. São Paulo: Ibracon, 2008. 674 p.

MEHTA, P. K. (2008). A glimpse into sustainable ternary-blended cements of the future. In: CONGRESSO BRASILEIRO DO CONCRETO, 50., 2008, Salvador. Apresentações... São Paulo: IBRACON, 2008, $39 \mathrm{p}$.

MELO, A. B. (2000). Influência da cura térmica (vapor) sob pressão atmosférica no desenvolvimento da microestrutura dos concretos de cimento Portland. 2000. $271 \mathrm{f}$. Tese (Doutorado em Ciência e Engenharia de Materiais) - Interunidades (Instituto de Física de São Carlos/ Instituto de Química de São Carlos/ Escola de Engenharia de São Carlos), Universidade de São Paulo, São Carlos, 2000.

METACAULIN DO BRASIL (2011). Especificação técnica. Disponível em: <http://www.metacaulim.com.br/tecnica/tecnica.htm>. Acesso em: 18 mar. 2011.

MOLION, L. C. B. (2008). Aquecimento global: uma visão crítica. Revista Brasileira de Climatologia, Rio de Janeiro, v. 3/4, p. 7-24, 2008.

MONKMAN, S.; SHAO, Y. (2010). Carbonation Curing of Slag-Cement Concrete for Binding $\mathrm{CO}_{2}$ and Improving Performance. Journal of Materials in Civil Engineering, v. 22, n. 4, p. 296-304, abr. 2010.

MÜLLER, N.; HARNISCH, J. (2008). A blueprint for a climate friendly cement industry. Gland/Switzerland: WWF International, 2008. 16 p.

NAIK, T. R.; SINGH, S. S.; HOSSAIN, M. M. (1995). Abrasion resistance of high-strength concrete made with class c fly ash. ACI Materials Journal. Detroit: ACI, v. 92, n. 6. p. 649659, nov.-dez. 1995.

NEPOMUCENO, A. A. (2005). Mecanismos de Transporte de Fluidos no Concreto. In: ISAIA, G. C. (ed.). Concreto: Ensino, Pesquisa e Realizações. São Paulo: IBRACON, 2005. Cap. 26, p. 793-827.

NEVILLE, A. M. (1982). Propriedades do Concreto. Tradução Salvador E. Giammusso da 3. ed. em inglês. São Paulo: Pini, 1982. 738 p.

(1997). Propriedades do Concreto. Tradução Salvador. E. Giammusso da 4. ed. em inglês. 2. ed. São Paulo: Pini, 1997. 828 p.

NGALA, V. T.; PAGE, C. L. (1997). Effects of carbonation on pore structure and diffusional properties of hydrated cement pastes. Cement and Concrete Research, v. 27, n. 7, jul. 1997, p. 995-1007.

OLIVEIRA, I. R.; STUDART, A. R.; PILEGGI, R. G.; PANDOLFELLI, V. C. (2000). Dispersão e empacotamento de partículas: princípios e aplicações em processamento cerâmico. São Paulo: Fazendo Arte Editorial, 2000. 195 p.

OLLIVIER, J. P.; MASO, J. C.; BOURDETTE, B. (1995). Interfacial Transition Zone in Concrete. Advanced Cement Based Materials. v. 2, n.1, jan. 1995, p. 30-38.

PAGE, C. L.; SHORT, N. R.; HOLDEN W. R. (1986). The influence of different cements on chloride-induced corrosion of reinforcing steel. Cement and Concrete Research. v. 16, n. 1, jan. 1986, p. 79-86. 
PAULETTI, C.; DAL MOLIN, D. C. C.; KAZMIERCZAK, C. S. (2007). Análise Comparativa de Diferentes Percentuais de $\mathrm{CO}_{2}$ em Ensaios Acelerados de Carbonatação. Revista IBRACON de Materiais. v. 3, n. 1, mar. 2007, p. 63-72.

PAULETTI, C.; POSSAN, E.; DAL MOLIN, D. C. C.; KAZMIERCZAK, C. S. (2008). Ensaios Acelerados de Carbonatação: Cuidados na Execução. In: CONGRESSO BRASILEIRO DO CONCRETO, 50., 2008, Salvador. Anais eletrônicos... São Paulo: IBRACON, 2008, p. 16.

PEREIRA, T. A. C. (2010) Concreto auto-adensável, de alta resistência, com baixo consumo de cimento Portland e com adições de fibras de lã de rocha ou poliamida. 2009. 281 f. Dissertação (Mestrado em Engenharia de Estrutura) - Departamento de Estruturas, Escola de Engenharia de Estruturas, Universidade de São Paulo, São Carlos, 2010.

PEREIRA, T. A. C.; LIBORIO, J. B. L. (2009). Técnicas de empacotamento de partículas para obtenção de CAD. In: CONGRESSO BRASILEIRO DO CONCRETO, 51., 2009, Curitiba. Anais eletrônicos... São Paulo: IBRACON, 2009, p. 13.

POSSAN, E. (2004). Contribuição ao estudo da carbonatação do concreto com adição de sílica ativa em ambiente natural e acelerado. 2004. 146 f. Dissertação (Mestrado em Engenharia) - Curso de Pós-graduação em Engenharia Civil, Universidade Federal do Rio Grande do Sul, Porto Alegre, 2004.

RASHEEDUZZAFAR; AL-SAADOUN, S. S.; AL-GAHTANI, A. S.; DAKHIL, F. H. (1990). Effect of tricalcium aluminate content of cement on corrosion of reinforcing steel in concrete. Cement and Concrete Research. v. 20, n. 5, set. 1990, p. 723-738.

REBMANN, M. S.; TRIGO, A. P. M.; LIBORIO, J. B. L. (2010). Melhorando as características mecânicas e microestruturais de concretos com cimento CPII-Z através de métodos de empacotamento e de dispersão de partículas. In: CONGRESSO BRASILEIRO DO CONCRETO, 52., 2010, Fortaleza. Anais eletrônicos... São Paulo: IBRACON, 2010, p. 16.

REIS, A. S.; TRISTÃO, F. A. (2008). Ladrilho hidráulico piso tátil com adição de resíduo de beneficiamento de granito. In: CONGRESSO BRASILEIRO DO CONCRETO, 50., 2008, Salvador. Anais eletrônicos... São Paulo: IBRACON, 2008, p. 14.

RIBEIRO, D. V. (2010). Influência da adição da lama vermelha nas propriedades e na corrosibilidade do concreto armado. 2010. 222 f. Tese (Doutorado em Ciência e Engenharia dos Materiais) - UFSCAR, São Carlos, 2010.

RILEM (1999). Recommendation of TC 116-PCD: tests for gas permeability of concrete: preconditioning of concrete test specimens for the measurement of gas permeability and capillary absorption of water. Materials and Structures, v. 32, n. 3, p. 174-179, abr. 1999.

RILEM (1984). Concrete Permanent Committee CPC-18: measurement of hardened concrete carbonation depth. Materials and Structures, v. 17, n. 6, p. 435-440, nov. 1984.

SANJUÁN, M. A.; OLMO, C. (2001). Carbonation resistance of one industrial mortar used as a concrete coating. Building and Environment, v. 36, n. 8, p. 949-953, out. 2001. 
SCRIVENER, K. L., CRUMBIE, A. K., LAUGESEN, P. (2004). The Interfacial Transition Zone (ITZ) Between Cement Paste and Aggregate in Concrete. Interface Science, The Netherlands, v. 12, n. 4, p. 411-421, out. 2004.

SILVA, F. G. (2006). Estudo da resistência à corrosão do concreto de alto desempenho frente à ação de cloretos. 2006. 220 f. Tese (Doutorado em Ciência e Engenharia dos Materiais) - Interunidades (Instituto de Física de São Carlos/Instituto de Química de São Carlos/ Escola de Engenharia de São Carlos), Universidade de São Paulo, São Carlos, 2006.

SILVA, I. J. (2000) Contribuição ao estudo dos concretos de elevado desempenho: propriedades mecânicas, durabilidade e microestrutura. 2000. 303 f. Tese (Doutorado em Ciência e Engenharia de Materiais) - Interunidades (Instituto de Física de São Carlos/ Instituto de Química de São Carlos/ Escola de Engenharia de São Carlos), Universidade de São Paulo, São Carlos, 2000.

SILVA, V. M. (2007). Ação da carbonatação em vigas de concreto armado em serviço, construídas em escala natural e reduzida. 2007. 281 f. Tese (Doutorado em Engenharia de Estruturas) - Escola de Engenharia de São Carlos, Universidade de São Paulo, São Carlos, 2007.

SILVA, F. G.; HELENE, P.; CASTRO-BORGES, P.; LIBORIO, J. B. L. (2009) Sources of variations when comparing concrete carbonation results. Journal of Materials in Civil Engineering, v. 21, n. 7, p. 333-342, jul. 2009.

SNIC - Sindicato Nacional da Indústria do Cimento. (2009). Relatório anual 2009. Rio de Janeiro: SNIC, 2009. $47 \mathrm{p}$.

TAYLOR, H. F. W. (1990). Cement Chemistry. London: Academic Press, 1992. 475 p.

TIBONI, R. (2007). A utilização da cinza da casca de arroz de termoelétrica como componente do aglomerante de compósitos à base de cimento Portland. 2007. $179 \mathrm{f}$. Dissertação (Mestrado em Engenharia de Estruturas) - Escola de Engenharia de São Carlos, Universidade de São Paulo, São Carlos, 2007.

TRIGO, A. P. M.; REBMANN, M. S.; LIBORIO, J. B. L. (2010). Uso da técnica de dopagem no tratamento da zona de transição de concretos com seixo rolado. In: CONGRESSO BRASILEIRO DO CONCRETO, 52., 2010, Fortaleza. Anais eletrônicos... São Paulo: IBRACON, 2010, p. 15.

TSO - THE HIGHWAYS AGENCY. HD 36/06: surfacing materials for new and maintenance construction. In: Design Manual for Roads and Bridges, volume 7, section 5, part 1, nov. 2006.

TUTIKIAN, B. F. (2007). Proposição de um método de dosagem experimental para concretos autoadensáveis. 2007. 162 f. Tese (Doutorado em Engenharia) - Programa de Pós-Graduação em Engenharia Civil, Universidade Federal do Rio Grande do Sul, Porto Alegre, 2007.

USACE - US ARMY CORPS OF ENGINEERS. EM 1110-2-2006: roller-Compacted Concrete. Washington: Department of the Army, 2000. 
VIECILI, F. A.; CREMONINI, R. A. (2010). Influência da utilização dos endurecedores de superfície na resistência à abrasão de pisos industriais de concreto. In: CONGRESSO BRASILEIRO DO CONCRETO, 52., 2010, Fortaleza. Anais eletrônicos... São Paulo: IBRACON, 2010, p. 11.

VDZ - Verein Deutscher Zementwerke (2008). Zement-Taschenbuch. 51. ed. Düsseldorf, Alemanha: Verlag Bau+Technik, 2008. 912 p.

WASSERMANN, R.; KATZ, A.; BENTUR, A. (2009). Minimum cement content requirements: a must or a myth? Materials and Structures, v. 42, n. 7, p. 973-982, ago. 2009.

WONG, H. C.; KWAN, A. K. H. (2005). Packing Density: a key concept for mix design of high performance concrete. In: Materials Science and Technology in Engineering Conference, Kowloon/Hong Kong, maio 2005. Proceedings... Hong Kong: HKIE Materials Division, 2005, p. 15.

WORRELL, E., PRICE, L., MARTIN, N., HENDRIKS, C., MEIDA, L. O. (2001). Carbon dioxide emissions from the global cement industry. Annual Review of Energy and the Environment. v. 26, p. 303-329, 2001.

YAMAMOTO, J. K.; KIHARA, Y.; COIMBRA, A. M.; MONTANHEIRO, T. J. (1997). Environmental Impact Reduction on the Production of Blended Portland Cement in Brazil. Environmental Geosciences, v. 4, n. 4, p. 192-206, dez. 1997.

YANG, M.; JENNINGS, H. M. (1995) Influences of mixing methods on the microstructure and rheological behavior of cement paste. Advanced Cement Based Materials, v.2, n.2, p.7078, mar. 1995.

YANG, Y; LEPECH, M. D.; YANG, E.-H; LI, V. C. (2009). Autogenous healing of engineered cementitious composites under wet-dry cycles. Cement and Concrete Research, v. 39, n. 5, p. 382-390, maio 2009

ZAMPIERI, V. A. (1989). Mineralogia e mecanismos de ativação e reação das pozolanas de argilas calcinadas. 1989. 191 f. Dissertação (Mestrado em Mineralogia e Petrologia) Instituto de Geociências, Universidade de São Paulo, São Paulo, 1989. 


\section{A. APÊNDICES}

\section{A.1 Resultados mecânicos detalhados}

Tabela 29 - Resistências à compressão, em MPa, dos corpos de prova dos concretos definitivos.

\begin{tabular}{|c|c|c|c|c|c|c|c|}
\hline \multirow{2}{*}{$\begin{array}{l}\text { idade } \\
\text { (dias) }\end{array}$} & \multirow{2}{*}{ CP } & \multicolumn{6}{|c|}{ Traços } \\
\hline & & V280 & V200 & VR4 & III280 & III210 & IIIR4 \\
\hline \multirow{5}{*}{7} & 1 & 50,3 & 39,1 & 34,9 & 36,5 & 20,4 & 24,8 \\
\hline & 2 & 55,5 & 34,4 & 32,7 & 37,3 & 21,0 & 22,9 \\
\hline & 3 & 53,7 & 35,1 & 33,9 & 39,9 & 19,8 & 21,9 \\
\hline & 4 & 54,7 & 40,1 & 36,0 & 44,6 & 20,3 & 23,0 \\
\hline & média & 53,5 & 37,2 & 34,4 & 39,6 & 20,4 & 23,2 \\
\hline \multirow{5}{*}{28} & 1 & 68,8 & 54,5 & 41,8 & 60,1 & 35,9 & 32,5 \\
\hline & 2 & 67,5 & 50,7 & - & 59,8 & 35,1 & 27,8 \\
\hline & 3 & 66,8 & 49,9 & 41,5 & 49,9 & 32,9 & 28,5 \\
\hline & 4 & 68,3 & 52,4 & 38,9 & 51,8 & 34,4 & 31,3 \\
\hline & média & 67,9 & 51,9 & 40,7 & 55,4 & 34,5 & 30,0 \\
\hline \multirow{5}{*}{63} & 1 & 66,6 & 49,6 & 42,3 & 64,3 & 42,5 & 35,6 \\
\hline & 2 & 67,5 & 60,1 & 38,1 & 59,1 & 42,1 & 32,0 \\
\hline & 3 & 68,6 & 56,5 & 42,4 & 58,7 & 44,6 & 31,4 \\
\hline & 4 & 71,1 & 59,3 & 41,6 & 57,4 & 42,9 & 31,6 \\
\hline & média & 68,4 & 56,4 & 41,1 & 59,9 & 43,0 & 32,6 \\
\hline \multirow{5}{*}{93} & 1 & 82,5 & 63,9 & 43,2 & 71,6 & 44,6 & 35,9 \\
\hline & 2 & 82,6 & 58,4 & 44,7 & 68,6 & 50,8 & 32,8 \\
\hline & 3 & 80,6 & 58,1 & 40,7 & 71,0 & 48,9 & 29,0 \\
\hline & 4 & 85,4 & 61,0 & 42,9 & 76,6 & 48,1 & 33,6 \\
\hline & média & 82,8 & 60,4 & 42,9 & 71,9 & 48,1 & 32,8 \\
\hline
\end{tabular}


Tabela 30 - Resistências à tração, em MPa, na flexão dos corpos de prova dos concretos definitivos.

\begin{tabular}{|c|c|c|c|c|c|c|c|}
\hline \multirow{2}{*}{$\begin{array}{l}\text { idade } \\
\text { (dias) }\end{array}$} & \multirow{2}{*}{ CP } & \multicolumn{6}{|c|}{ Traços } \\
\hline & & V280 & V200 & VR4 & III280 & III210 & IIIR4 \\
\hline \multirow{4}{*}{28} & 1 & 7,9 & 6,8 & 4,6 & 7,6 & 4,9 & 5,1 \\
\hline & 2 & 7,9 & 5,9 & 4,3 & 7,1 & 5,4 & 4,5 \\
\hline & 3 & 9,1 & 5,9 & 4,5 & 6,9 & 4,9 & 4,5 \\
\hline & média & 8,3 & 6,2 & 4,5 & 7,2 & 5,1 & 4,7 \\
\hline \multirow{4}{*}{63} & 1 & - & - & - & 6,1 & 6,1 & 5,5 \\
\hline & 2 & - & - & - & 6,2 & 6,2 & 5,5 \\
\hline & 3 & - & - & - & 6,0 & 6,0 & 6,0 \\
\hline & média & - & - & - & 6,1 & 6,1 & 5,7 \\
\hline
\end{tabular}

Observação: não foram realizados ensaios com 63 dias de idade para os concretos com cimento CP V-ARI.

Tabela 31 - Módulos de elasticidade, em GPa, dos corpos de prova dos concretos definitivos.

\begin{tabular}{|c|c|c|c|c|c|c|c|}
\hline \multirow{2}{*}{$\begin{array}{l}\text { idade } \\
\text { (dias) }\end{array}$} & \multirow{2}{*}{$\mathrm{CP}$} & \multicolumn{6}{|c|}{ Traços } \\
\hline & & V280 & V200 & VR4 & III280 & III210 & IIIR4 \\
\hline \multirow{4}{*}{7} & 1 & 51,5 & 43,9 & 33,1 & 43,3 & 27,7 & 24,7 \\
\hline & 2 & 49,3 & 39,6 & 32,2 & 48,0 & 24,3 & 25,1 \\
\hline & 3 & 48,9 & 45,1 & 36,9 & 46,1 & 29,8 & 27,4 \\
\hline & média & 49,9 & 42,9 & 34,1 & 45,8 & 27,3 & 25,7 \\
\hline \multirow{4}{*}{28} & 1 & 51,3 & 46,9 & 40,0 & 51,0 & 43,3 & 34,6 \\
\hline & 2 & 50,9 & 52,5 & 40,5 & 50,0 & 45,9 & 35,1 \\
\hline & 3 & 52,1 & 47,7 & 46,1 & 51,3 & 41,4 & 38,9 \\
\hline & média & 51,4 & 49,0 & 42,2 & 50,8 & 43,5 & 36,2 \\
\hline \multirow{4}{*}{63} & 1 & 61,0 & 53,6 & 39,8 & 48,1 & 56,0 & 35,2 \\
\hline & 2 & 60,6 & 50,1 & 40,9 & 47,6 & 50,4 & 39,5 \\
\hline & 3 & 56,2 & 52,0 & 40,4 & 48,7 & 52,7 & 32,7 \\
\hline & média & 59,3 & 51,9 & 40,4 & 48,1 & 53,0 & 35,8 \\
\hline \multirow{4}{*}{93} & 1 & 55,9 & 51,9 & 43,3 & 55,1 & 47,1 & 34,2 \\
\hline & 2 & 57,9 & 49,4 & 41,6 & 56,1 & 49,4 & 29,2 \\
\hline & 3 & 54,9 & 51,5 & 43,0 & 57,4 & 48,7 & 33,7 \\
\hline & média & 56,2 & 50,9 & 42,6 & 56,2 & 48,4 & 32,4 \\
\hline
\end{tabular}




\section{A.2 Traços auxiliares}

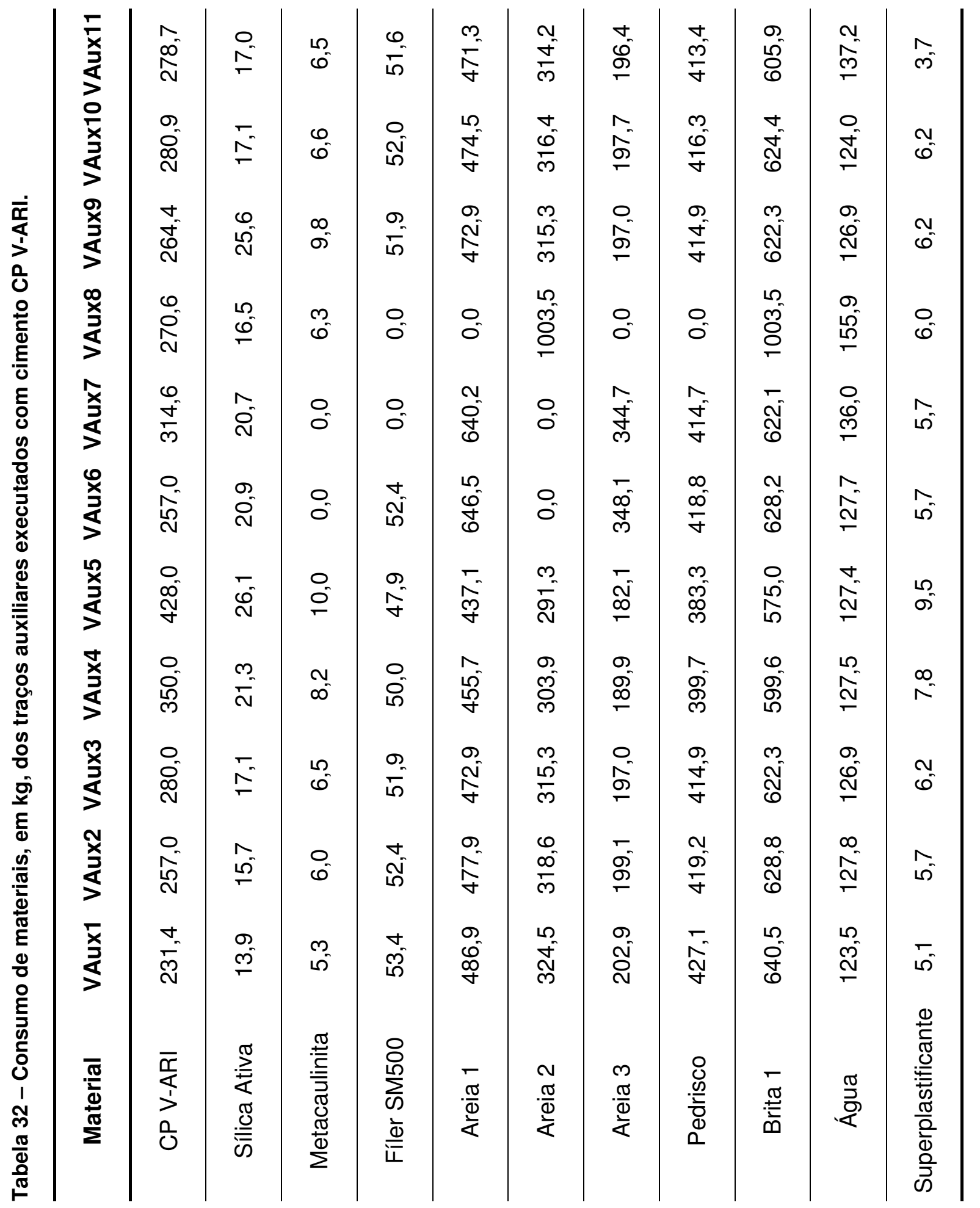




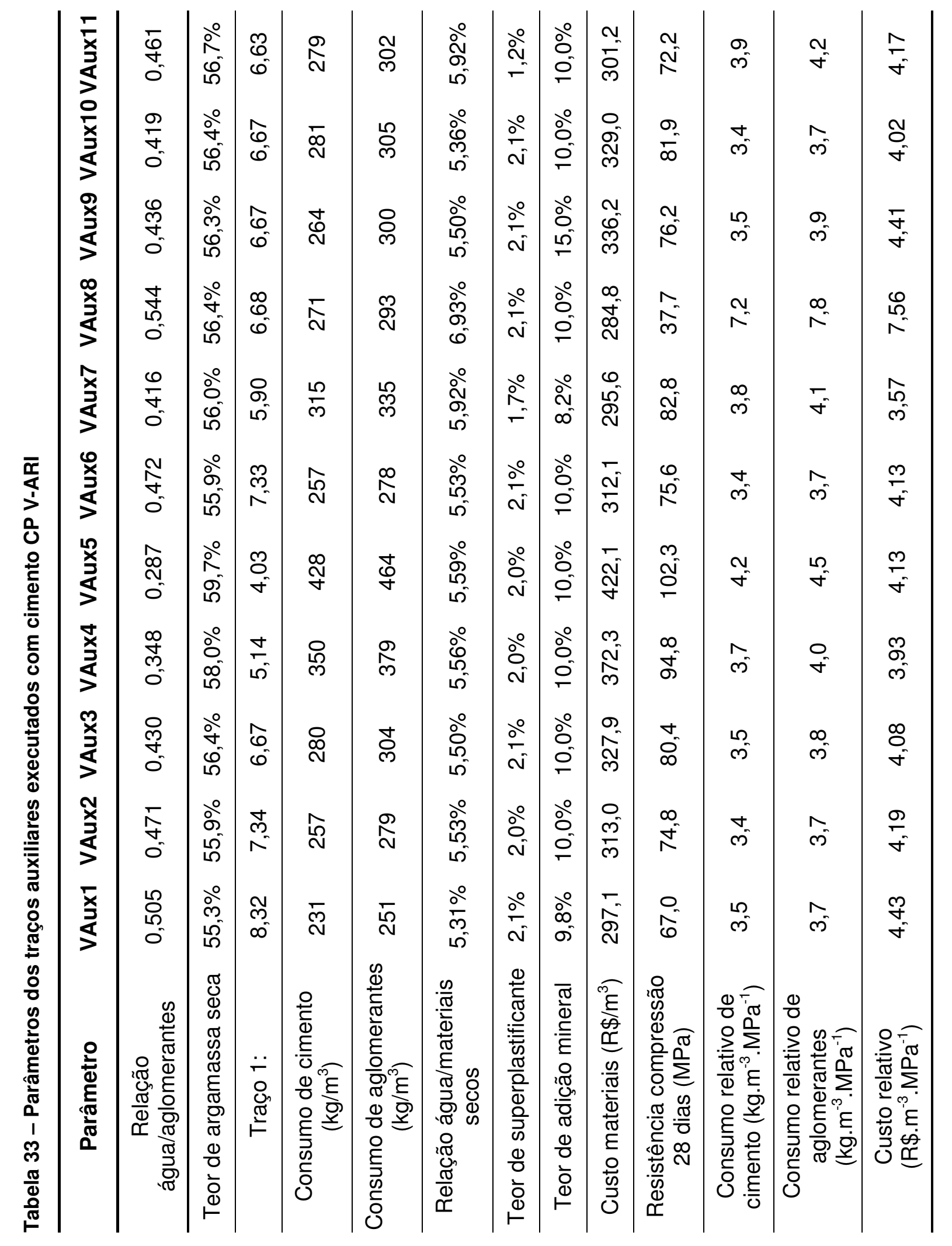


Tabela 34 - Consumo de materiais, em kg, dos traços auxiliares executados com cimento CP III-40-RS.

\begin{tabular}{ccccc}
\hline Material & IIIAux1 & IIIAux2 & IIIAux3 & IIIAux4 \\
\hline CP III-40-RS & 211,0 & 238,0 & 258,5 & 278,3 \\
\hline Sílica Ativa & 13,3 & 15,0 & 16,3 & 17,5 \\
\hline Metacaulinita & 5,1 & 5,8 & 6,3 & 6,7 \\
\hline Fíler SM500 & 53,1 & 52,6 & 52,9 & 52,2 \\
\hline Areia 1 & 484,0 & 479,3 & 482,2 & 475,7 \\
\hline Areia 2 & 322,7 & 319,5 & 321,5 & 317,1 \\
\hline Areia 3 & 201,7 & 199,7 & 201,0 & 198,2 \\
\hline Pedrisco & 424,6 & 420,4 & 423,0 & 417,2 \\
\hline Brita 1 & 636,7 & 630,6 & 634,5 & 625,8 \\
\hline Água & 133,2 & 130,0 & 117,1 & 119,8 \\
\hline Superplastificante & 4,7 & 5,3 & 5,7 & 6,2 \\
\hline
\end{tabular}

Tabela 35 - Parâmetros dos traços auxiliares executados com cimento CP III-40-RS.

\begin{tabular}{|c|c|c|c|c|}
\hline Parâmetro & IIIAux1 & IIIAux2 & IIIAux3 & IIIAux4 \\
\hline $\begin{array}{c}\text { Relação } \\
\text { água/aglomerantes }\end{array}$ & 0,593 & 0,515 & 0,429 & 0,408 \\
\hline $\begin{array}{c}\text { Teor de } \\
\text { argamassa seca }\end{array}$ & $54,9 \%$ & $55,5 \%$ & $55,9 \%$ & $56,3 \%$ \\
\hline Traço 1: & 9,05 & 7,95 & 7,36 & 6,75 \\
\hline $\begin{array}{c}\text { Consumo de cimento } \\
\left(\mathrm{kg} / \mathrm{m}^{3}\right)\end{array}$ & 211 & 238 & 259 & 278 \\
\hline $\begin{array}{c}\text { Consumo de } \\
\text { aglomerantes }\left(\mathrm{kg} / \mathrm{m}^{3}\right)\end{array}$ & 229 & 259 & 281 & 303 \\
\hline $\begin{array}{c}\text { Relação água/materiais } \\
\text { secos }\end{array}$ & $5,78 \%$ & $5,64 \%$ & $5,03 \%$ & $5,17 \%$ \\
\hline $\begin{array}{c}\text { Teor de } \\
\text { superplastificante }\end{array}$ & $2,0 \%$ & $2,0 \%$ & $2,0 \%$ & $2,0 \%$ \\
\hline Teor de adição mineral & $10,0 \%$ & $10,0 \%$ & $10,0 \%$ & $10,0 \%$ \\
\hline Custo materiais $\left(\mathrm{R} \$ / \mathrm{m}^{3}\right)$ & 283,2 & 301,0 & 316,1 & 328,5 \\
\hline $\begin{array}{c}\text { Resistência compressão } \\
28 \text { dias (MPa) }\end{array}$ & 41,8 & 50,1 & 67,2 & 67,6 \\
\hline $\begin{array}{l}\text { Consumo relativo de } \\
\text { cimento }\left(\mathrm{kg} \cdot \mathrm{m}^{-3} \cdot \mathrm{MPa}^{-1}\right)\end{array}$ & 5,1 & 4,8 & 3,8 & 4,1 \\
\hline $\begin{array}{c}\text { Consumo relativo de } \\
\text { aglomerantes } \\
\left(\mathrm{kg} \cdot \mathrm{m}^{-3} \cdot \mathrm{MPa}^{-1}\right) \\
\end{array}$ & 5,5 & 5,2 & 4,2 & 4,5 \\
\hline $\begin{array}{l}\text { Custo relativo } \\
\left(\mathrm{R} \$ \cdot \mathrm{m}^{-3} \cdot \mathrm{MPa}^{-1}\right)\end{array}$ & 6,78 & 6,01 & 4,71 & 4,86 \\
\hline
\end{tabular}




\section{A.3 Diagramas de dosagem dos concretos auxiliares convencionais}
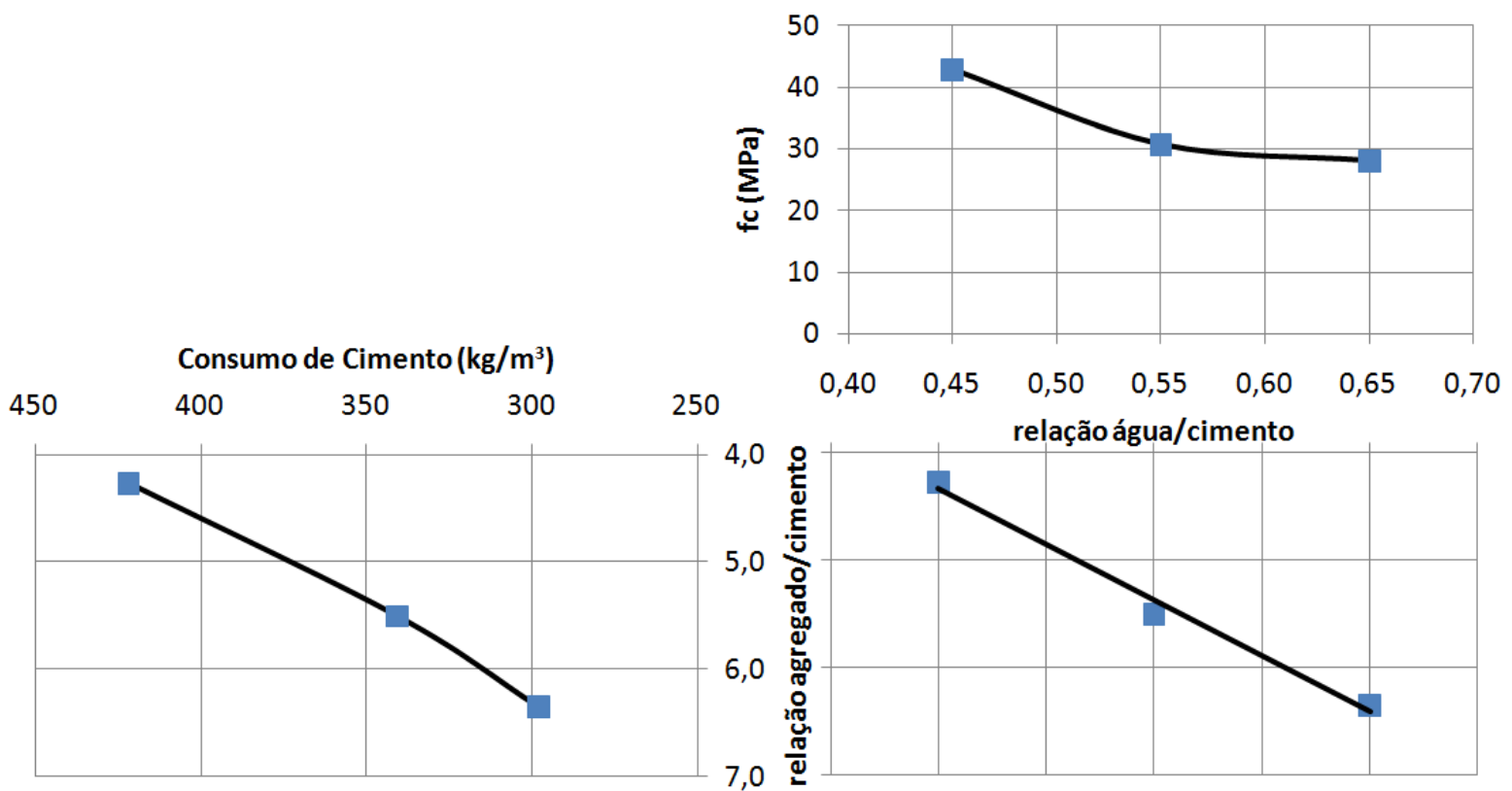

Figura 61 - Diagrama de dosagem para os concretos convencionais com cimento CP V-ARI.

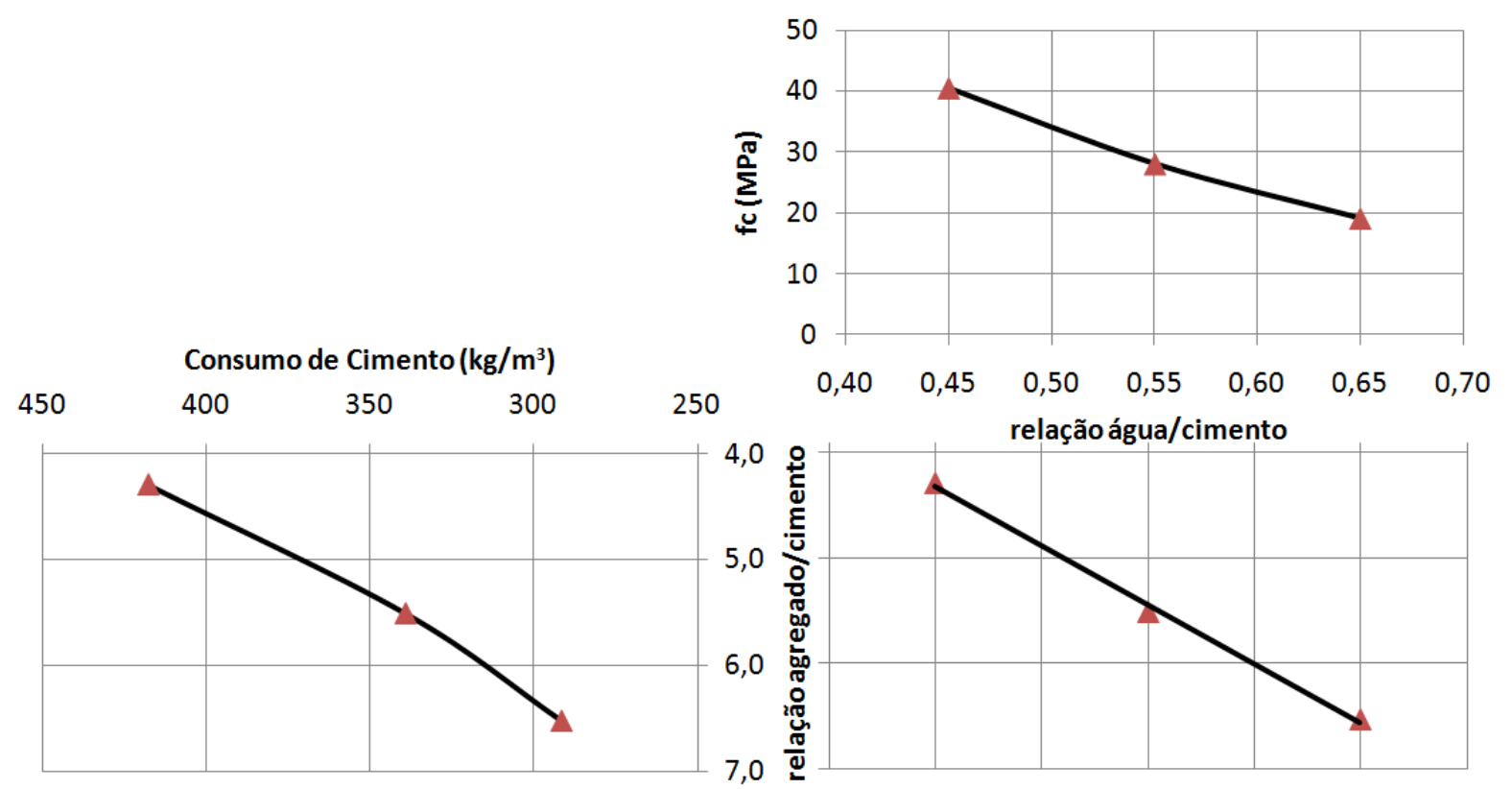

Figura 62 - Diagrama de dosagem para os concretos convencionais com cimento CP III-40-RS. 


\section{A.4 Fotos carbonatação}

Nas figuras abaixo são registradas as evoluções da carbonatação nos diversos concretos analisados, para os tempos de exposição até 96 dias à atmosfera concentrada de $\mathrm{CO}_{2}$.

6 dias
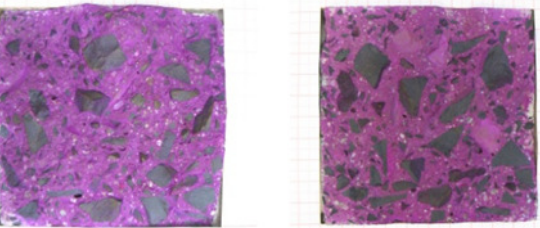

14 dias

6 dias
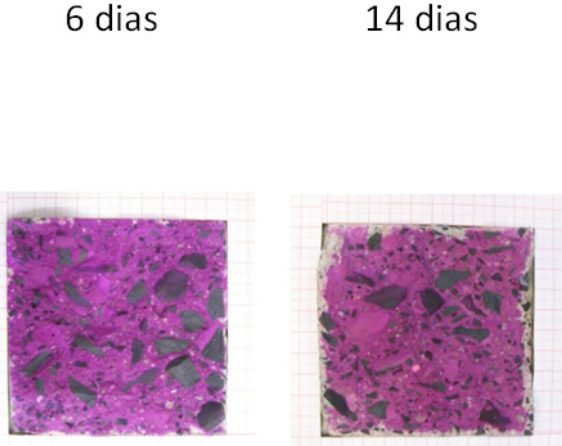

28 dias
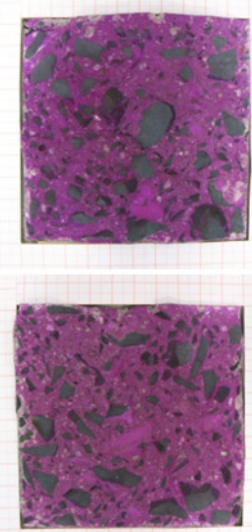

56 dias
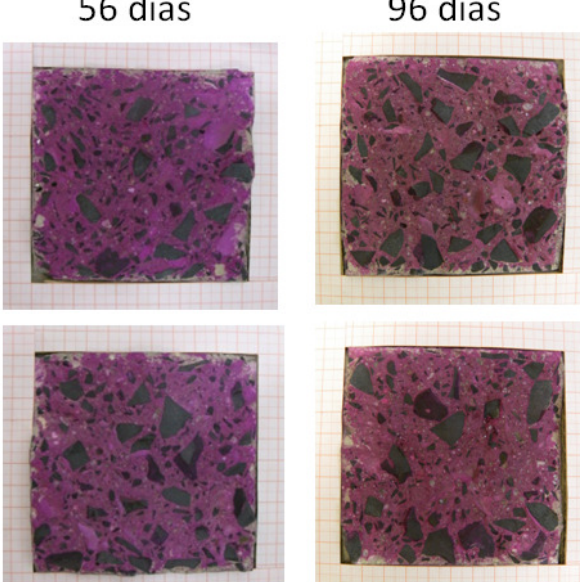

Figura 63 - Evolução da carbonatação no concreto V280
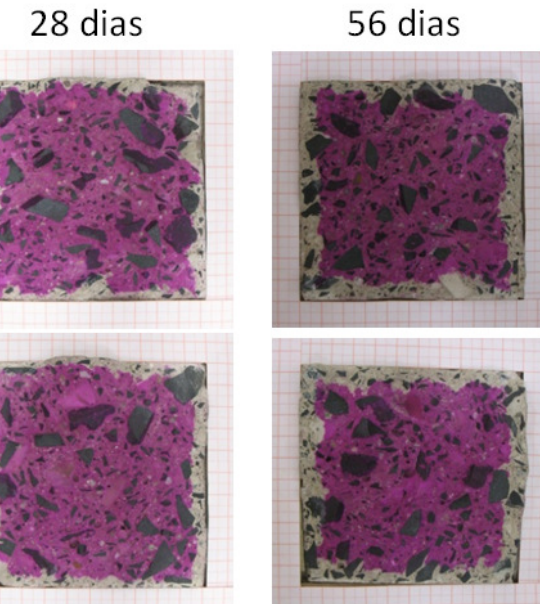

96 dias

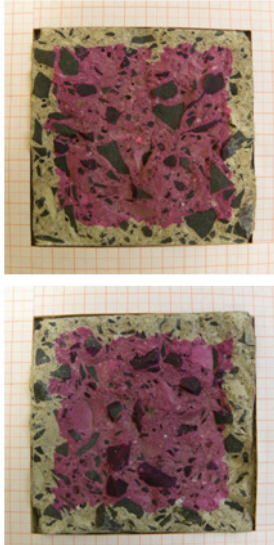

Figura 64 - Evolução da carbonatação no concreto V200 


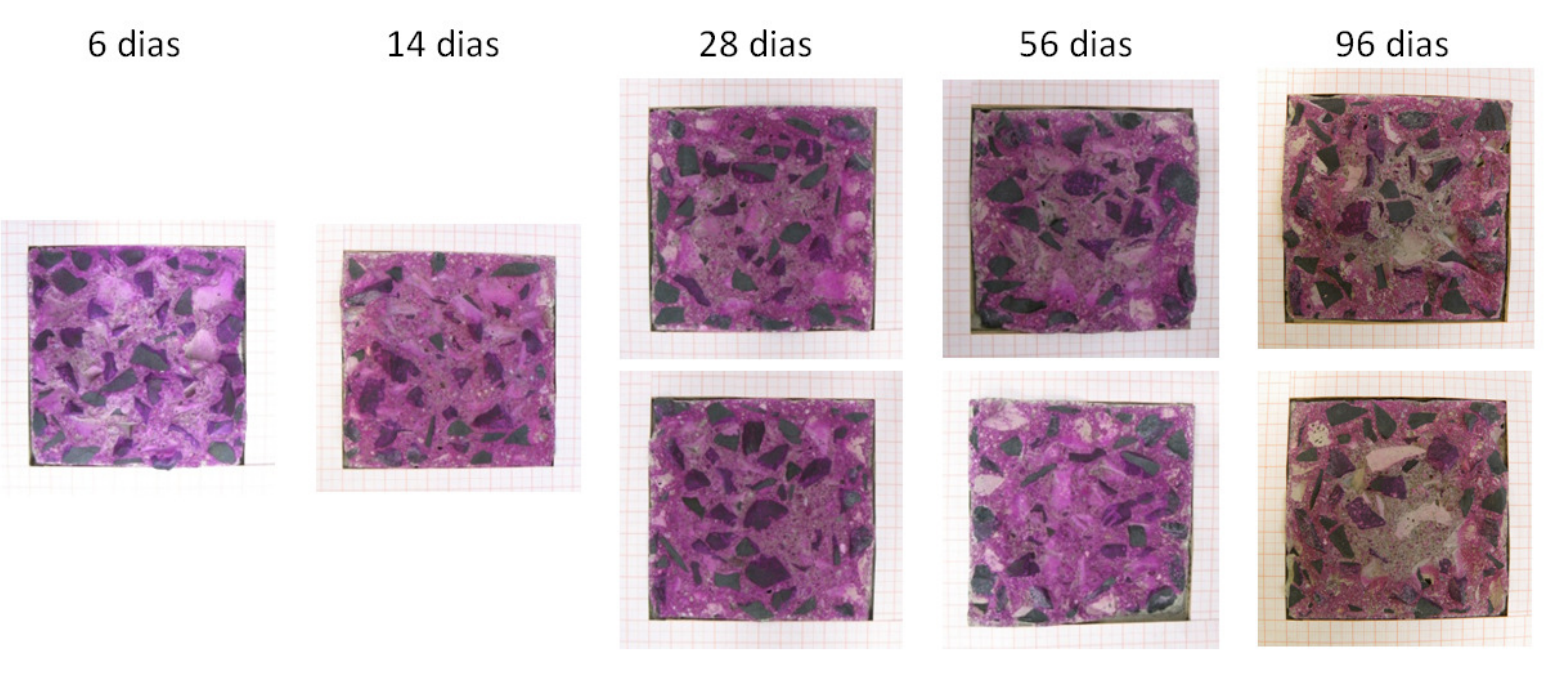

Figura 65 - Evolução da carbonatação no concreto VR4

6 dias

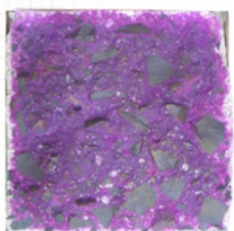

14 dias

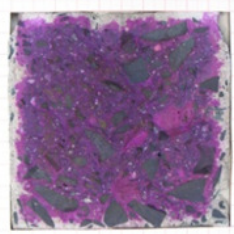

28 dias
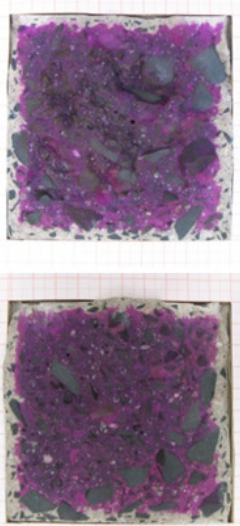

56 dias
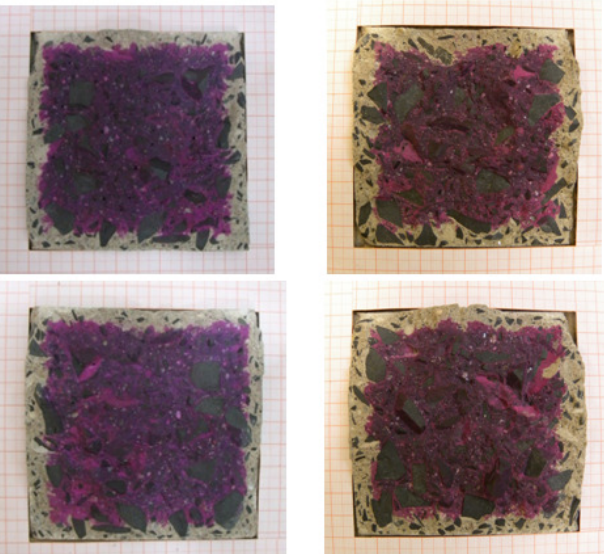

Figura 66 - Evolução da carbonatação no concreto III280 

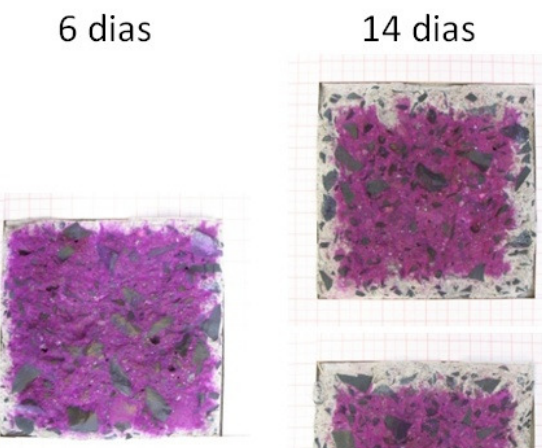

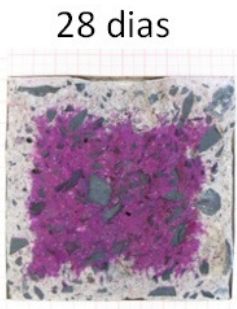

56 dias
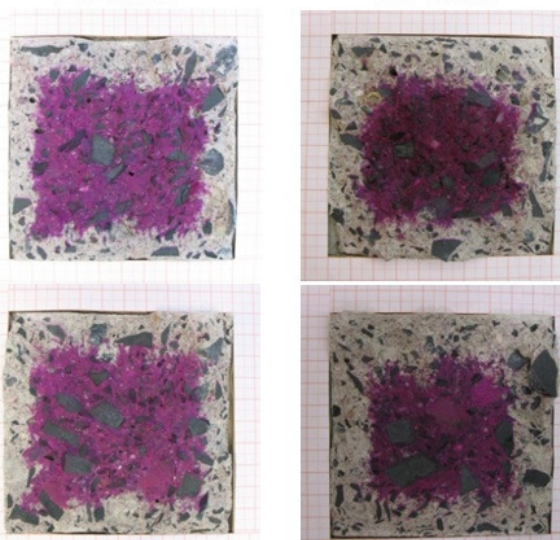

96 dias
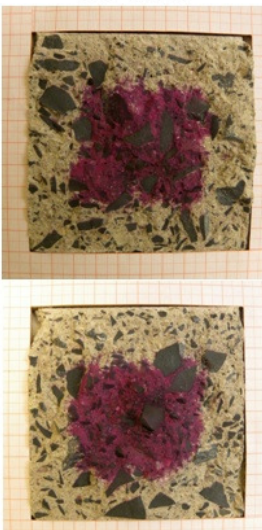

Figura 67 - Evolução da carbonatação no concreto III210

6 dias

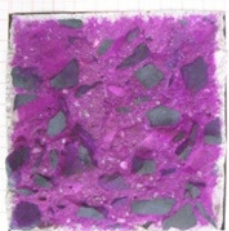

14 dias
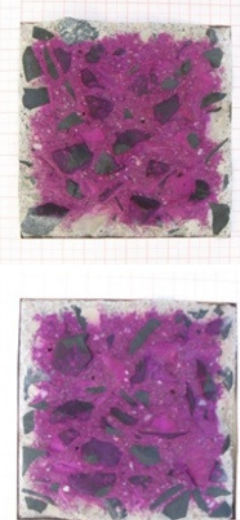

28 dias
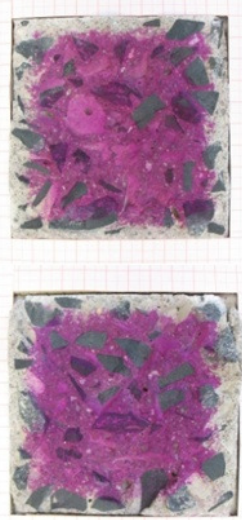

56 dias

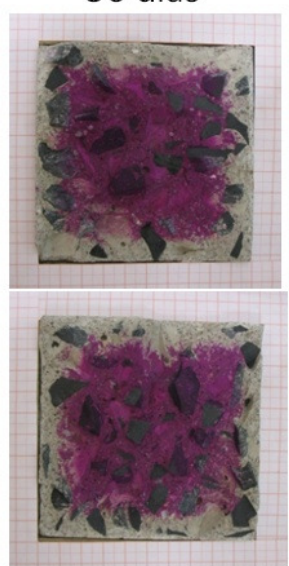

96 dias
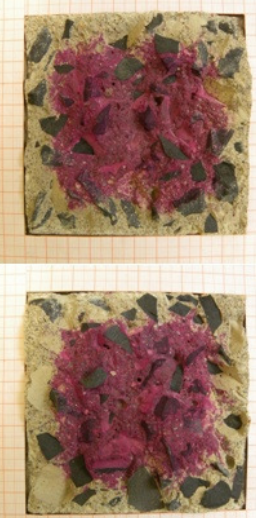

Figura 68 - Evolução da carbonatação no concreto IIIR4 